ANMMAL SNAPSHOTS

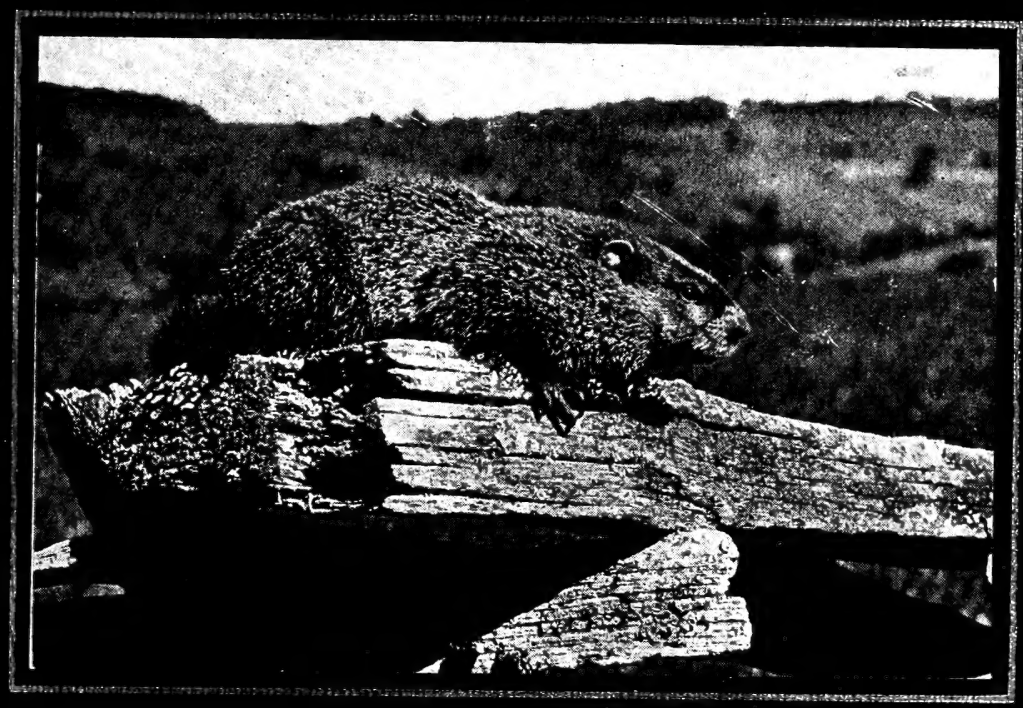

!

\title{
SLLAS A.LOTTRIDGE
}




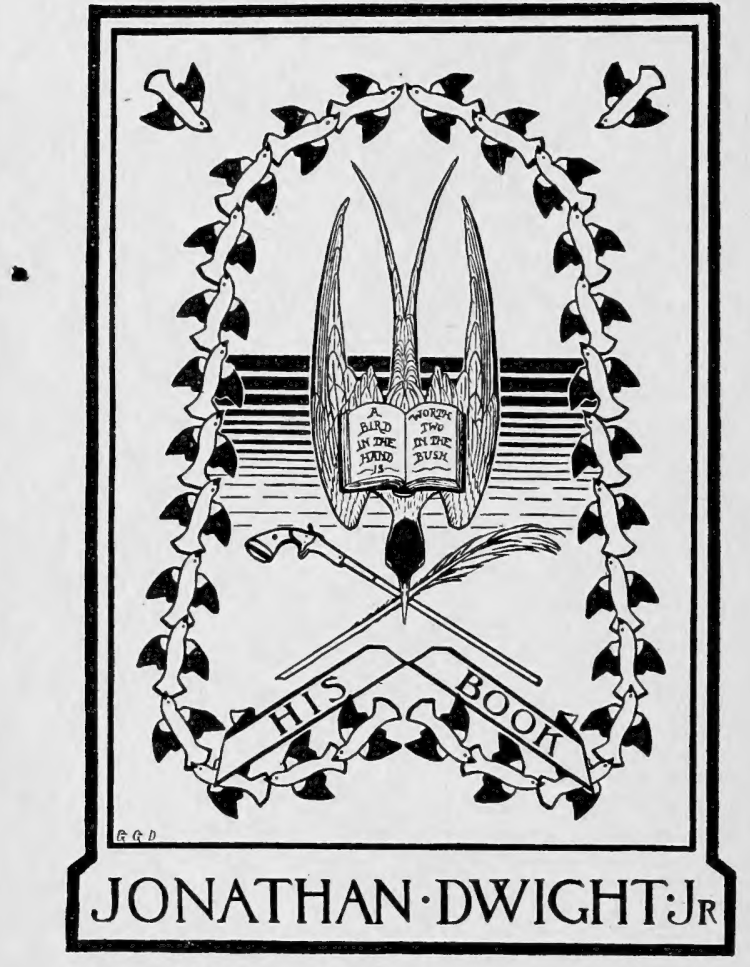






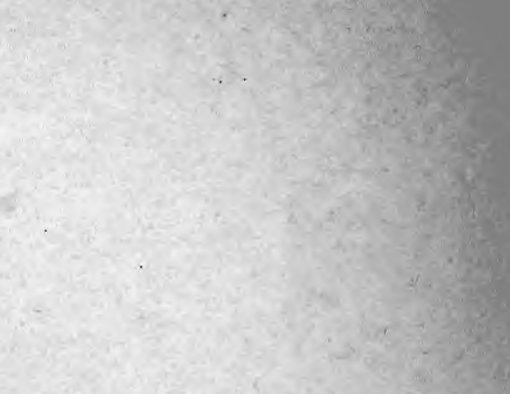

$x+2 x^{2}$
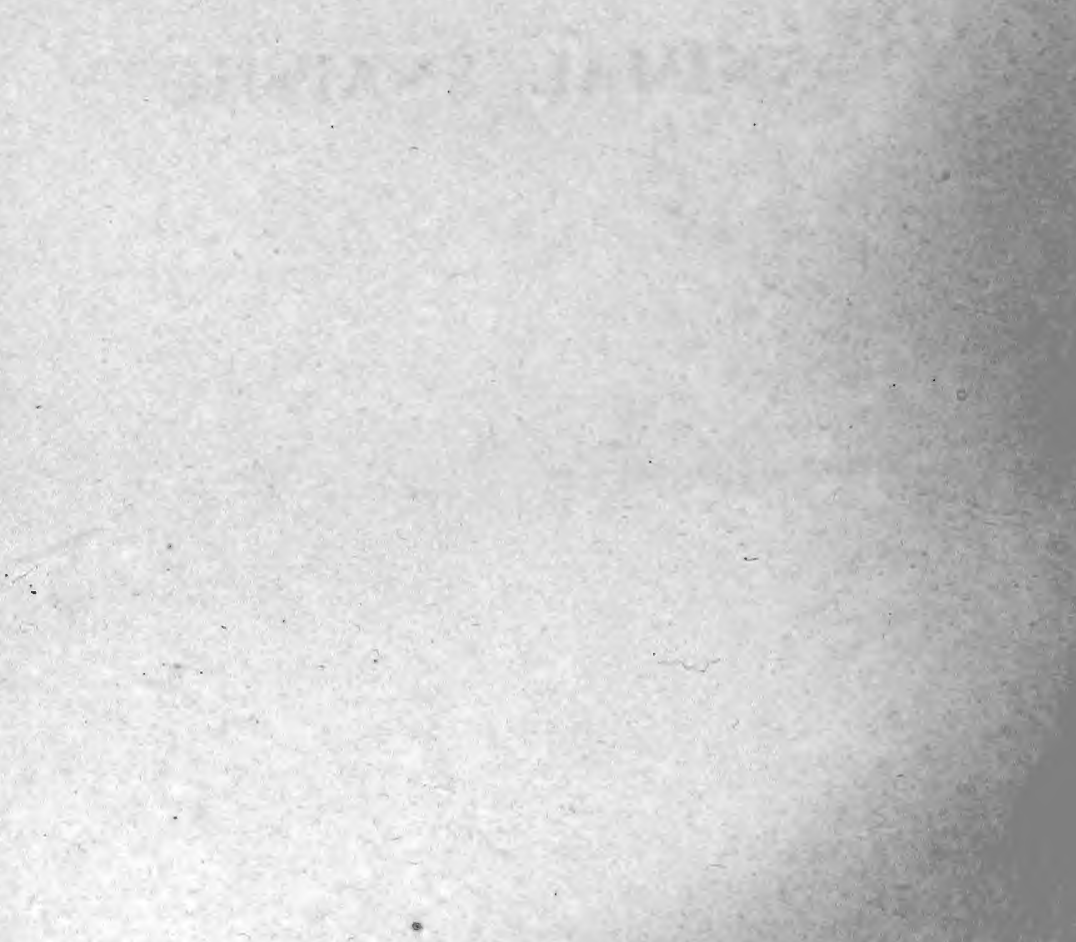
ANIMAL SNAPSHOTS 



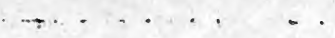

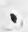




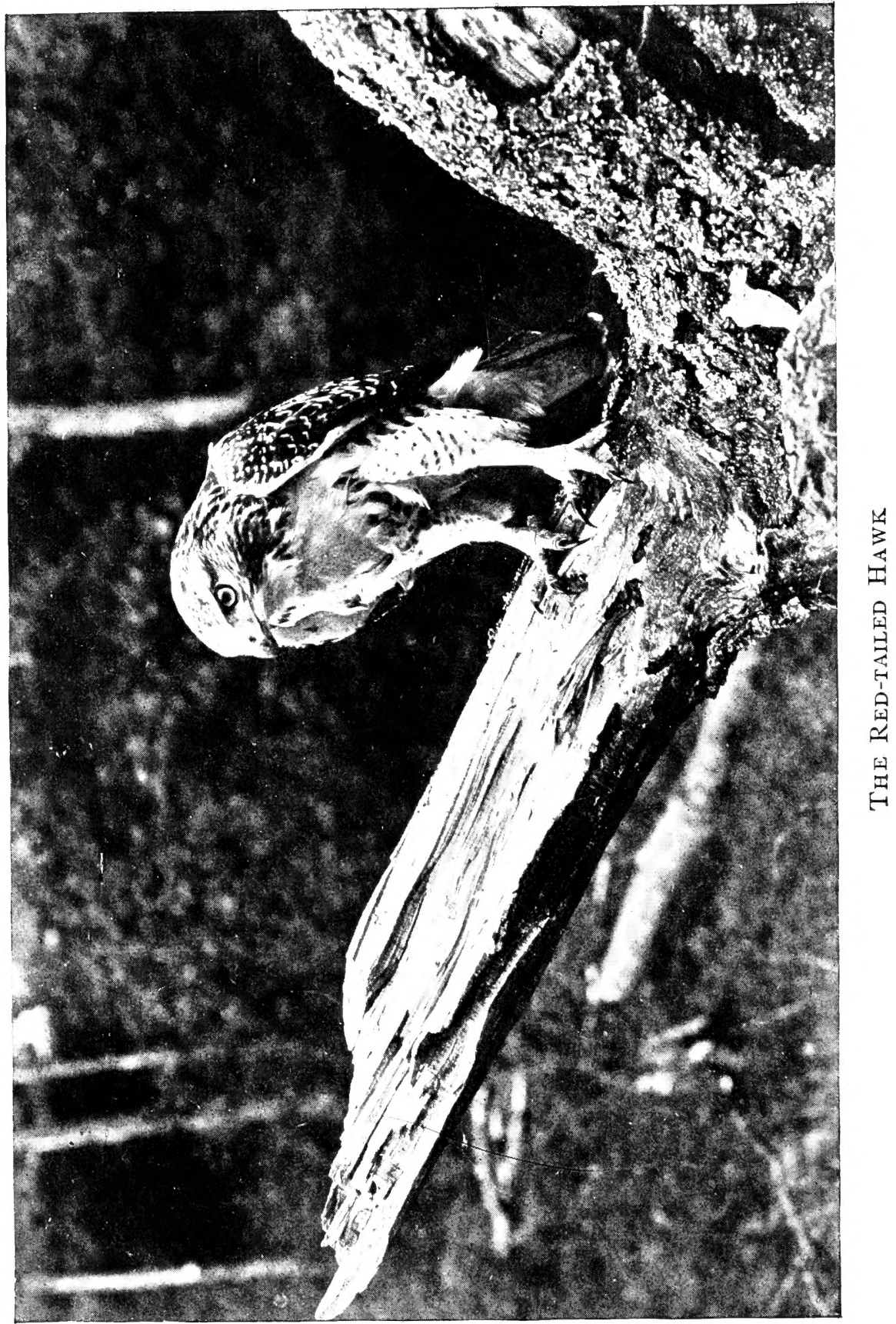




\section{ANIMAL SNAPSHOTS}

AND HOW MADE,

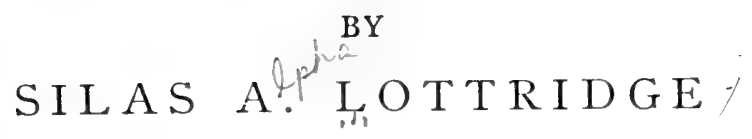

Illustrated with Photographs from Nature

by the Author

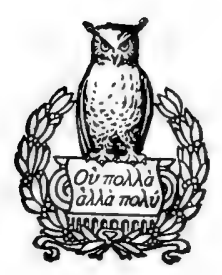

NEIV YORK

HENRY HOLT AND COMPANY

I 905 


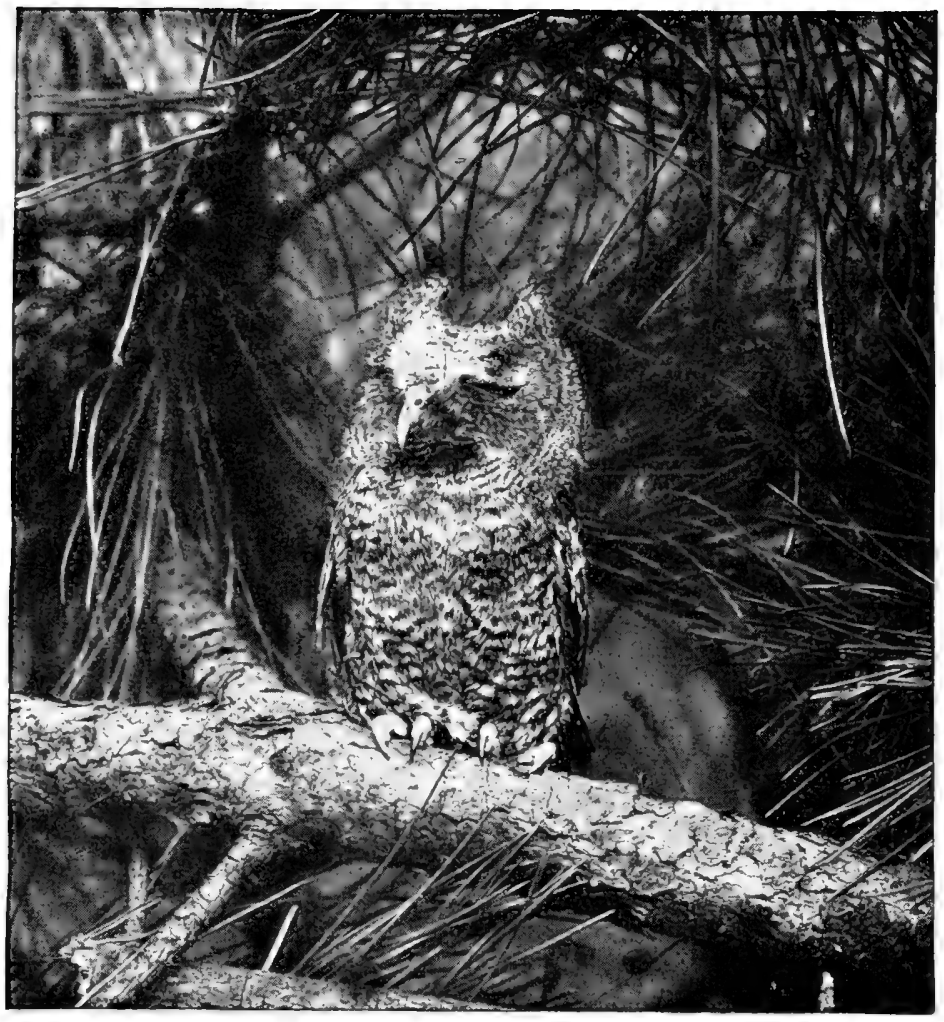

Copyright, 1905, by HENRY HOLT AND COMPANY

Published October, 1905 
To My Mother

This Book is Affectionately

Dedicated 


\section{PREFACE}

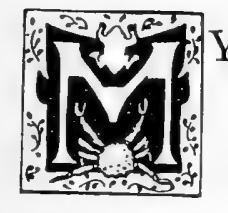

Y ideal vacation is one that affords healthful pleasure not only for the time being but for the remainder of the year-that furnishes something to which I can turn for recreation and enjoyment after the working day is over. An outing of this sort is a twofold luxury, and can perhaps best be had in fields and woods that are far from the distracting influences of the city. It is here in the simple life of camping-vacations, where the work of housekeeping is reduced to the essentials, that I have learned the art of doing for myself what I had previously supposed absolutely necessary to have others do for me. A month of this sort of life stimulates my muscles and gives me an appetite that a boy might envy. And rest! - when Mother Nature has her own way and presides over my sleep, then indeed I rest until I feel like a new being.

For years I have spent my vacations in this ideal way, photographing and studying our friends in fur and feathers, in their native haunts. I enter into 
their lives as much as possible, in order to know their habits and wild ways-how they live, and how they care for their young. This I have found to be an endless and ever-increasing source of both knowledge and enjoyment.

In the sketches to follow, I have attempted to make the photographs as far as possible illustrate the facts. The pictures were not made specially for each sketch, but have been selected from those best suited for the purpose. It should be borne in mind that it has taken years to make some of the series, such, for example, as the illustrations for the muskrat and woodchuck.

The text is a simple narrative concerning the birds and mammals that I have come to know a little about, and there is no attempt at a display of technical knowledge. The facts are all from my own observations and experiences, except in a few instances where I have drawn upon trustworthy sources.

I hope that both sketches and pictures may help to extend living interest in the animals about us; and I would urge our young people, especially, to make a closer study of them in the woods and fields, for it will surely add greatly to their health, pleasure, and knowledge. It will also spread the popular interest in birds and animals awakened within the 
last few years, which has accomplished considerable in the way of protection, especially among the birds. This has been brought about largely through the influences of clubs and societies that have been formed for the purpose of studying wild life.

I am under obligations to various landowners for the privilege of tramping about their fields, and in many instances for valuable assistance. To the boys, also, who have helped me in so many ways I extend sincere thanks; for without them some of my best pictures would never have been possible. I am under special obligations to Miss Caroline E. Alden for literary criticism and reviewing, and to Mr. Edward H. Dutcher for many valuable suggestions as to text and arrangement.

Thanks are due the proprietors of St. Nicholas and Field and Stream for permission to republish articles which have appeared in those magazines.

East Orange, N. J.,

March, 1905. 
$\therefore$ 


\title{
CONTENTS
}

\author{
PART I
}

MAMMALS

PAGE

The Camera and its Accessories. ............... I

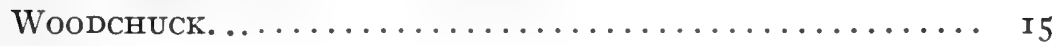

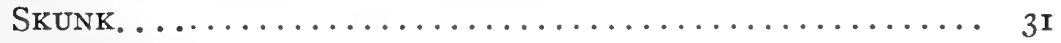

RACCOON................................. 46

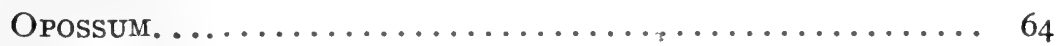

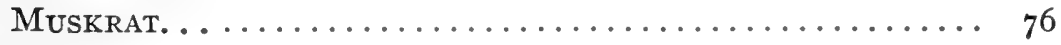

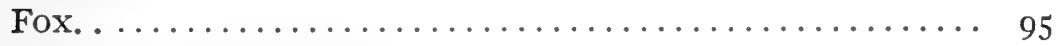

Photographing a Wild Fox................... Ii

White-footed Mouse. . . . . . . . . . . . . . . . I 24

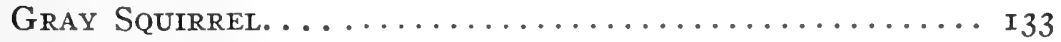

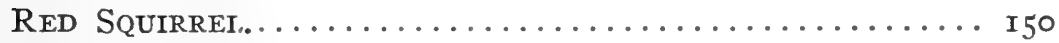

Flymg Squirrel......................... I62

\section{PART II}

BIRDS

Migration of BIRds.................... I77

BluebIRd ................................... I93

RoBIN................................. 205

Why the Robin's Breast is Red................. 2 I3

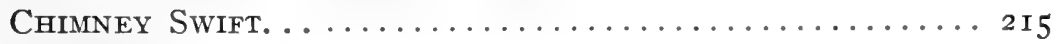

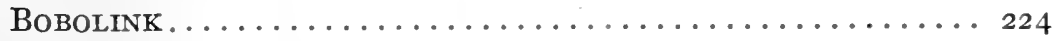

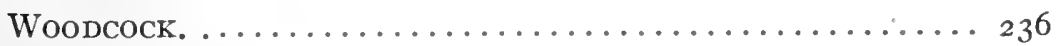

Crows. ................................... 249

Old White Whng............................. 267

Great Horned Owl. ........................ 288

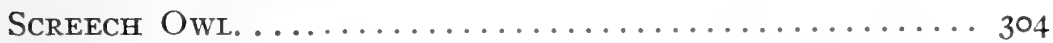

The "Hen Hawk" and How it was Photographed..... 3 I6

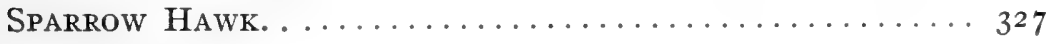





\section{LIST OF ILLUSTRATIONS}

THe Red-TAILED HAWK....................... Frontispiece

The Graphic, with Release Apparatus............. 3

The Tilting Tripod in Use..................... 9

NATURE'S BRIDGe FOR Her FoUR-FoOted CHILdREN....... I4

The Summer Home of the Woodchuck.............. in

On the Lookout............................ I9

The Mother Listening for Unusual Sounds.......... 23

The Mother Woodchuck on the Fence............ 27

They Fell AsLeep............................... 3०

The SkUnk.................................. $3^{2}$

The Rear One of the Line.................... 43

Raccoon Creek.............................. 5

The Raccoon................................. 59

"Playing 'Possum".............................. $6_{3}$

A Characteristic Pose........................ $6_{7}$

A Chicken-House Thief......................... 69

Feasting on Eggs............................. $7 \mathrm{I}$

"O LoRd, Uncle Robert, a 'Possum!".............. 73

"De 'Possum and de Coon"........................ 74

An Ideal Muskrat Country. .................... 79

The Winter Lodge............................ 8I

A Burrow Exposed showing a Few Apples Stored for

Winter................................ 84

A Trap Baited for Muskrat.................... 87

Muskrat Reclining on the Log................... 90

Swimming.................................. 92

A Muskrat Stream in Winter.................... 93

A Typical fox Country. ......................... 95 


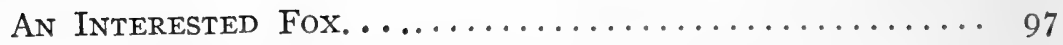

The Dream of the Wild Fox................ I07

The Stone Wall where the Dog Lost the Trail...... I20

The Fox Watching the Hound................ 122

White-footed Mouse....................... I27

The Nest of the White-footed Mouse............ I 3 I

The Gray Squirrel Forest in Winter............. I 39

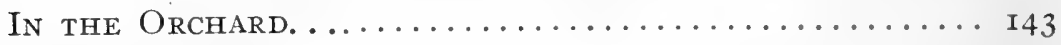

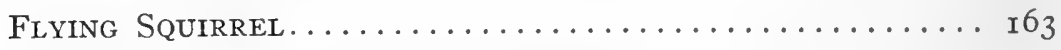

The Home of the Flying Squirrel. ............. I67

Nest ANd Eggs of the Song Sparrow............ r 76

IN WINTER. . . . . . . . . . . . . . . . . . I 77

Section Removed showing Interior with Nest and Eggs. I93

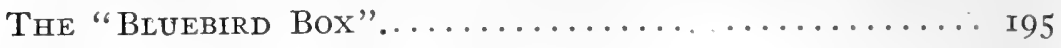

Section Removed Showing Microphone. ............ 197

The Bluebird Tree.......................... 20 I

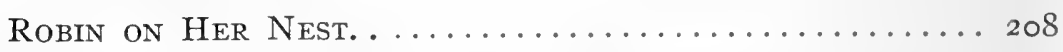

Young Robins Thirteen Days Old....................... 2 i2

The Feeding-ground of the Chimney Swift......... 2 I5

Nest and Young of the Chimney Swift........... 220

The Nesting-Place of the Bobolink. ............. 224

Nest and Eggs of the Bobolink. ................ 229

The Land of THE WOodcock................... 239

The Woodcock-First, Second, and Third Photographs. 243

" " Fourth and Fifth Photographs...... 247

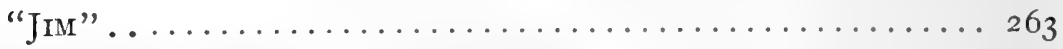

"Old White Wing." (Mounted) ................. 269

Entrance to the Little Ravine................ 275

"Old White Wing" and his Band. (Drawing)....... 28I

Death of "Old White Wing." (Drawing). . ....... 285

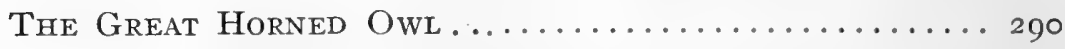

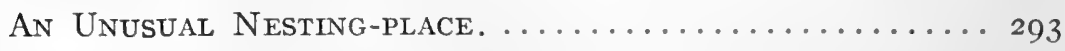

The Great Horned Owl Watching the Dog.......... 30 I

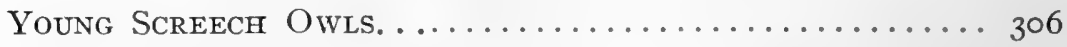

"Billy and Betty"........................ 3I

Billy Wondering What the fuss Was About......... 315

The Home and Feeding-ground of the Red-tailed Hawk. . 3r9

Looking the Situation Over..................... 323 


\section{List of Illustrations $\quad \mathrm{xv}$}

PAGE

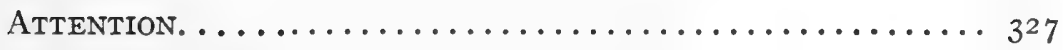

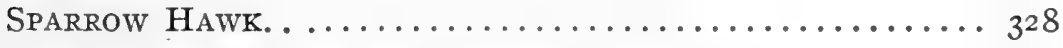

Feeding-ground of the Sparrow Hawk........... 33 I

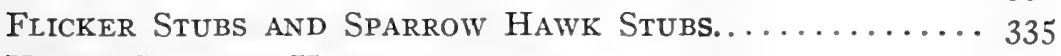

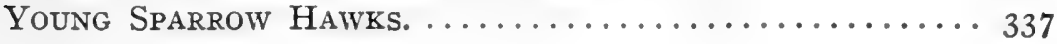




\section{THE CAMERA AND ITS ACCESSORIES}

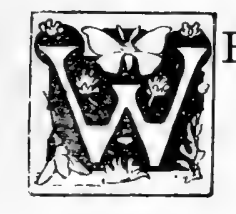

HAT kind of a camera do you use in making your animal pictures?" This question I have been asked more than any other concerning my avocation in the fields and woods. As the camera is only one of the essentials, I will endeavor to describe not only the instrument, but also its accessories. However, let me hasten to add that this is not for the expert, but is intended only for those who are just starting in pursuit of healthful recreation, and familiarity with the organic creation about them.

It is quite as difficult for the novice to know what to buy as it is to photograph many of our wild animals; for most supply houses know nothing about what is necessary in actual work. I will cite one instance illustrating this point: It was not long ago that I was standing in one of our large reliable supply houses waiting for an order to be filled, when a lady entered and approached the counter. A callow youth came 
forward to wait upon her, and she explained that she wished a photographic outfit suitable to make lifesize pictures of flowers, insects, and various naturalhistory objects, all of which were small. The "salesman" advised a front-draw camera $5 \times 7$; with long bellows and a wide-angle lens, to be used as a sort of hand camera, without a tripod. The outfit amounted to about forty dollars, but for the purpose that it was intended to serve it was worthless; twentyfive dollars rightly expended would have purchased a good working outfit.

I will not weary the novice with an account of the various cameras used by myself, but will describe the one which I most frequently employ for allaround work. This camera is known as the Graphic, and is a $5 \times 7$. My reasons for using this make are based upon my varied experiences in the field and woods. In it the first requirement of the camera is admirably fulfilled-it is put together to stay; even

a little rain and several tumbles from trees have not as yet sent it to the repair-shop. Some of the other essentials that I prize highly are the long bellows, reversible back, falling front, swing-back, and clamps that hold when set. The platforms are particularly strong and steady, owing to hinges that extend their whole width. This is of the greatest importance, 
since, as far as possible, all vibration must be overcome.

Upon the advantages of the front and rear draw, and of the swing-back, I wish to speak more in detail. When an object is to be photographed life-size, the lens should be clamped in a certain position and the

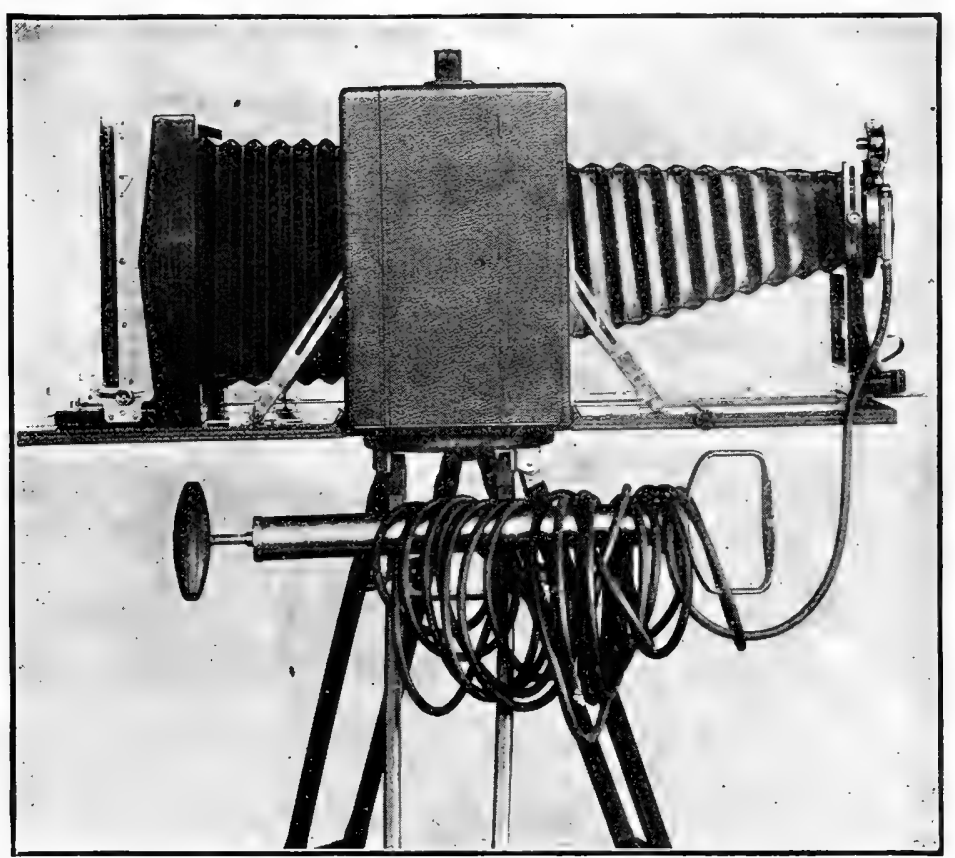

The Graphic, with Release Apparatus

focusing done at the rear. Otherwise you will find yourself doing two things simultaneously, which in this case is not practical; increasing your image in size, and, at the same time, attempting to sharpen it. 


\section{The Camera and its Accessories}

With only a front focus, it very often means changing the position of the tripod from one to three times, which is of course disastrous to quick and accurate manipulation. The swing-back should be used more than it is usually, especially for near-by pictures, as the objects themselves are often not "plumb" with the plate. This condition occurs very frequently in photographing birds' nests or other objects on or near the ground. I recommend the swing-back to the beginner. Do not purchase a field camera without it, and, having it, consider it not as an ornament, but as a most useful accessory. In photographing a nest on the ground, one quarter or one half its natural size; the portion nearest the lens is so near, while the opposite side is so far away, that a small diaphragm must be used, and consequently a long exposure to obtain a sharp image. This is not desirable; for a harsh negative may be the result. Moreover, if the object has life it probably will not remain quiet for so long an exposure, and a worthless blurred negative is the result. By the use of the swing-back, the long exposure and the lack of detail on one side of the negative may be largely overcome with a medium stop; for it must be remembered that moving the swing-back out of the vertical increases the distance from the lens to one edge of 


\section{The Camera and its Accessories}

the plate, while the distance to the other edge is decreased. This will have a tendency to sharpen the whole plate equally, producing a more uniform negative in less time.

In purchasing a lens, there are several absolutely essential things to be considered-perfect definition, depth of focus, covering capacity, and speed. Beginner, beware of making the mistake of attempting to economize by using a small lens! If a $4 \times 5$ lens will make a certain picture in one second, with the diaphragm at $\mathrm{F}$ I6, a $5 \times 7$ will do it better and in less time, for it is using the centre of the lens. I use on my $\mathrm{F}$ and $\mathrm{S}$ Graflex $4 \times 5$ a $7 \times 9$ lens.

A long-focus lens is desirable for animal photography, because the greater the length of focus, the larger will be the image, and the less the distortion.

For several years I have used a Goerz lens, series III, and for all-around work I have found nothing superior, although in some of the new series there are probably better lenses. My lens has an equivalent focus of ten and three-quarter inches; but by using the front lens alone, I have a focus of about seventeen inches. - This is of great importance to the field photographer; for with the shorter focus at the distance of sixty feet, an object twenty inches high forms an image half an inch in height; while 


\section{The Camera and its Accessories}

with the second focus at the same distance from the object, the image is three-quarters of an inch in height. Many times I find it of great assistance to use the longer focus, especially when coaxing some timid animal into position to be photographed.

If it were simply an increase in the size of the image, it could be obtained with the telephoto attachment. Within the last few years there has been a great deal of literature upon this subject, and one might be led to believe that with the purchase of a good telephoto the difficulties in photographing wild animals would suddenly vanish. A telephoto may be adjusted to almost any lens, the magnification usually varying from two to six diameters; but its use in animal photography in general is very limited, and principally for this reason-that the length of the exposure is increased. The telephoto can be used where an absolutely solid foundation for the camera to rest upon may be secured, for the least vibration will ruin the picture. It will probably be some time before the telephoto will be perfected so as to become a practical apparatus for animal photographers.

In using a quick lens and for all snapshot work it is absolutely necessary to make the exposures by means of a shutter. Most shutters are in connection with the lens barrel, but the focal plane is not, and 


\section{The Camera and its Accessories}

of this I will speak later in connection with the Graflex camera. I use the Iris Diaphragm Shutter for want of a better one. There are others, such as the Sector and Volute. These three are probably among the best shutters; but even these are not by any means perfect. The one with the greatest speed is so delicate in its construction that it is not to be depended upon. The so-called uniform and reliable action of these shutters is not always trustworthy. One of the principal difficulties with the Iris Diaphragm Shutter is that the greatest efficiency of the light cannot be utilized, on account of the mechanical construction of the shutter. This is probably true of most shutters whose openings are controlled by "leaves." The smaller the opening in the diaphragm, the longer will be the exposure; but to compensate for this, there is an increase in depth of focus, and greater covering capacity of the lens. Such numbers as $\mathrm{F}_{4}, \mathrm{~F} 8, \mathrm{~F}$ I6, and $\mathrm{F} 32$ mean, practically, that if the right exposure with a certain light for $\mathrm{F} 8$ is one second, F I6 will require two seconds, and $\mathrm{F} 32$ four seconds. In general, the smaller the opening in the diaphragm, the sharper will be the negative; but the really artistic effects can only be produced by the larger openings which impart to the picture a softness very pleasing to the eye. 
From the lens and the shutter let us turn our attention to the other end of the bellows, for here we meet with no little difficulty in the form of the plate-holder. The unsuspecting are inveigled into purchasing a light holder, because the weight of the outfit is thus somewhat decreased. All such plate-holders as the "Fairy" and the "Feather-weight" should have no room in the closet of the real nature photographer. They are toys, and should be treated as such-mere jokes at the expense of the purchaser. I have experienced the saddest realities with such plate-holders, as well as with slides that in sunlight were not lighttight for half a minute. Certain compositions of rubber and celluloid are probably the best for slides, but these need careful treatment. Great care must be exercised in the selection of plate-holders, and even then they need careful watching; for parts that are supposed to be automatic do not always work.

A very essential part of the field "camera is what it rests upon - the tripod. The tripod that I have used for some time is known as the "F and S crown tripod number three." Various parts of this I have reinforced with screws and metal. To many this may seem unnecessary, but having seen two serious mishaps to valuable cameras from the use of poor frail tripods, I speak feelingly upon the subject. 
The excellent points about the tripod in question are: the head is wide, thus affording a broad foundation

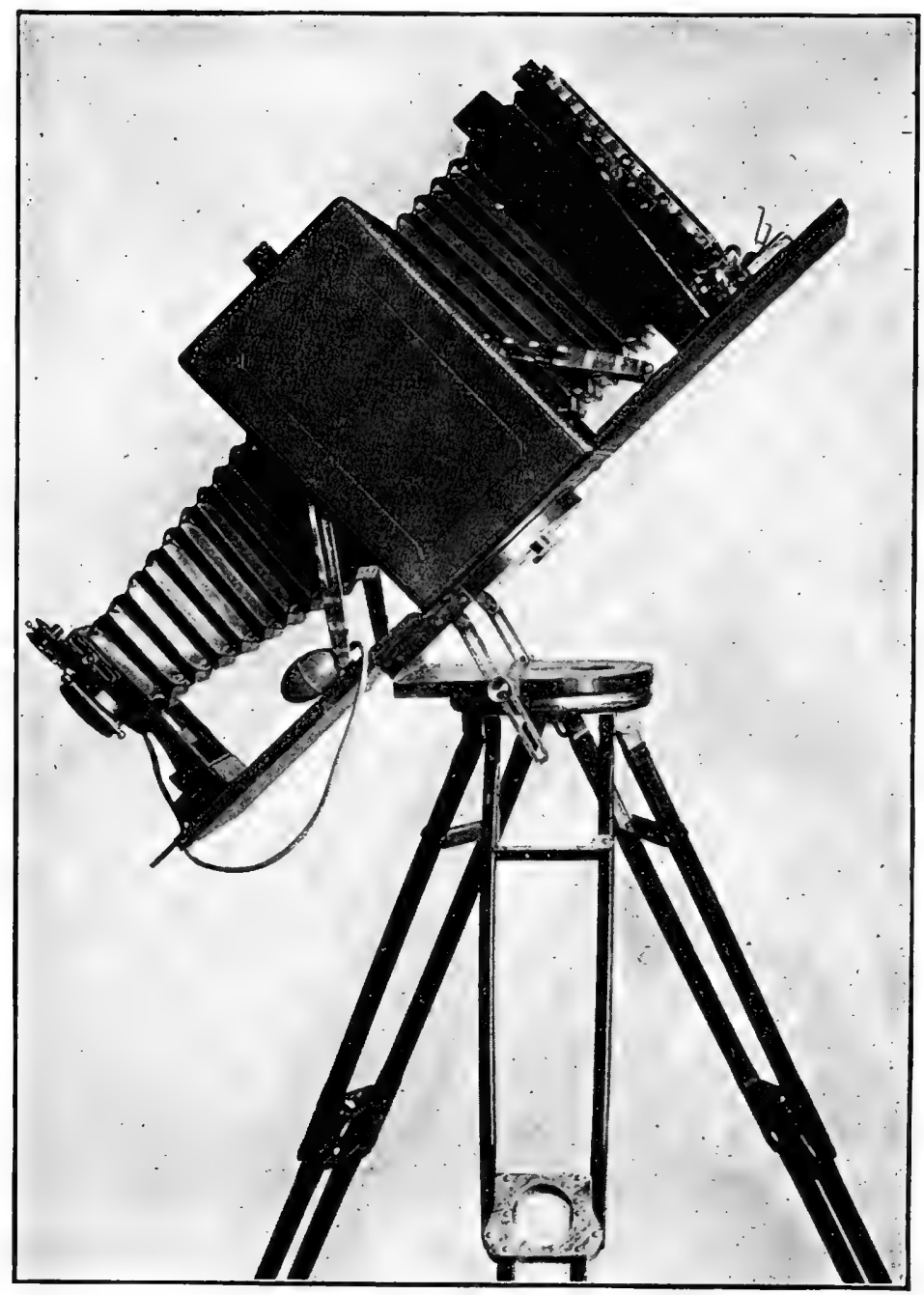

The Tilting Tripod in Use

for the camera, and is made of three pieces of wood securely fastened together, to prevent warping and 
splitting; metal-tipped sockets prevent loose joints; and the expansion brackets make it impossible for the legs to be detached from the head by any ordinary accident. The crown tripod has a head of sufficient size and strength to hold firmly a tilting tripod top. I have made use of this attachment so often, and it has been so valuable to me, that I strongly recommend it to all nature photographers. By aid of it the camera may be tilted at any angle from the horizontal to ninety degrees. It screws directly to the tripod head, and the camera is fastened to it by means of a thumb-screw. In fact, the tilting top is similar to a double tripod head hinged at one side and capable of being tilted and held in position by means of two adjustable levers. The portability, compactness, and solidity will at once suggest its usefulness to the thoughtful field-worker.

So much, then, for the tripod camera; it has solidity and weight, but it will do the work. You will grow weary in carrying it up hill and through tangled thickets, but it is as true in photography as in all else that whatever of value is accomplished, in one way or another an equivalent must be expended.

In animal photography it is often necessary to use a hand camera; and I have found none equal to the Graflex. The Graflex is the outcome of the "double- 


\section{The Camera and its Accessories II}

decker," Reflex, and other similar cameras. It is strongly made, requires but one lens, has the best plate-holders that I have ever used, and a long bellows. The image is in view up to the instant the exposure is made. The focal-plane shutter gives great speed, but as it uses the maximum quantity of light, the negative, under normal conditions, is well timed.

In writing this brief sketch of the camera and its accessories, I have tried to keep in mind at all times the real perplexities of the beginner. I hope that I have made it sufficiently clear, so that the initial expenditure will be in the right direction, and that the purchaser will not be burdened either by unnecessary outlay or by useless apparatus. 
i 


\section{PART I}

\section{MAMMALS}




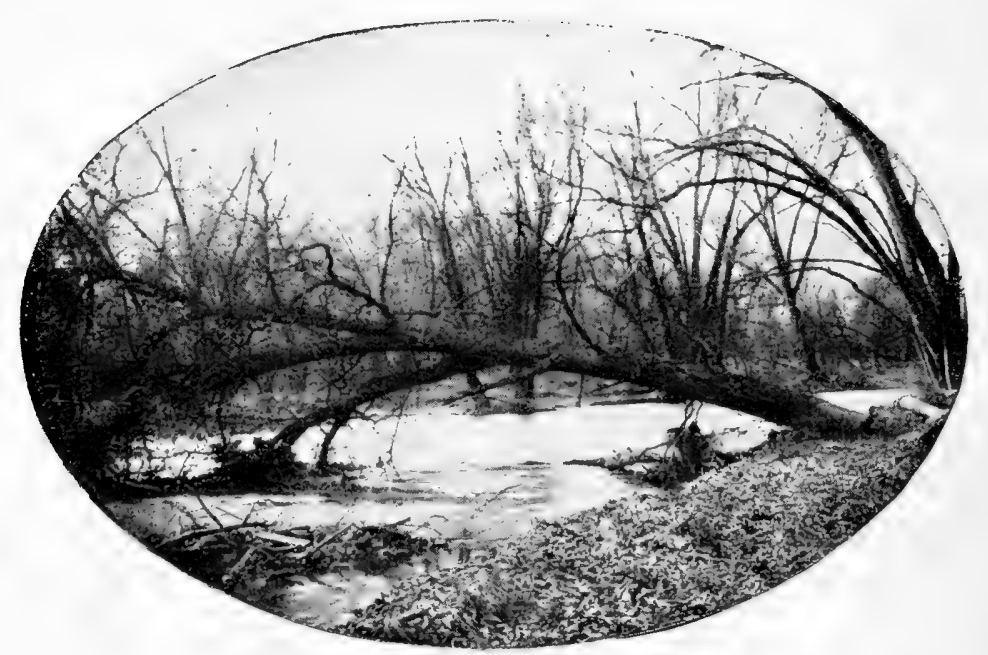

NATURE's Bridge FOR Her Four-Footed ChILdREN 


\section{THE WOODCHUCK}

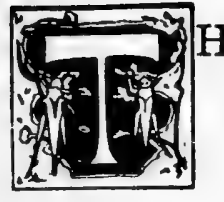

HE woodchuck is well known among the farmer boys and girls throughout the Middle and Eastern States, for he is as much a part of the farm as is the brook or the sugarbush.

In form he is far from graceful, especially in the latter part of the summer when his body becomes very fat and pouchy. The color of his fur varies from a reddish brown to a grizzled gray or, occasionally, black; while his teeth, like those of the squirrel and prairie-dog, are strong and well adapted for cutting.

The woodchuck is of the earth earthy, and there is a peculiar odor about the place where he dwells, for he lives not in the lap, but in the bosom, of Mother Earth,-however his summer home may be in a wall or stone-heap. The woodchuck of the present day is rather inclined to desert the old home in the woods, where he fed upon tender bark and roots of various kinds, and become a dweller in the field near the clover-patch and garden. Here he is so destructive 


\section{I6 The Woodchuck}

that he has become a special object of persecution by the farmers, and from early spring until fall a con-

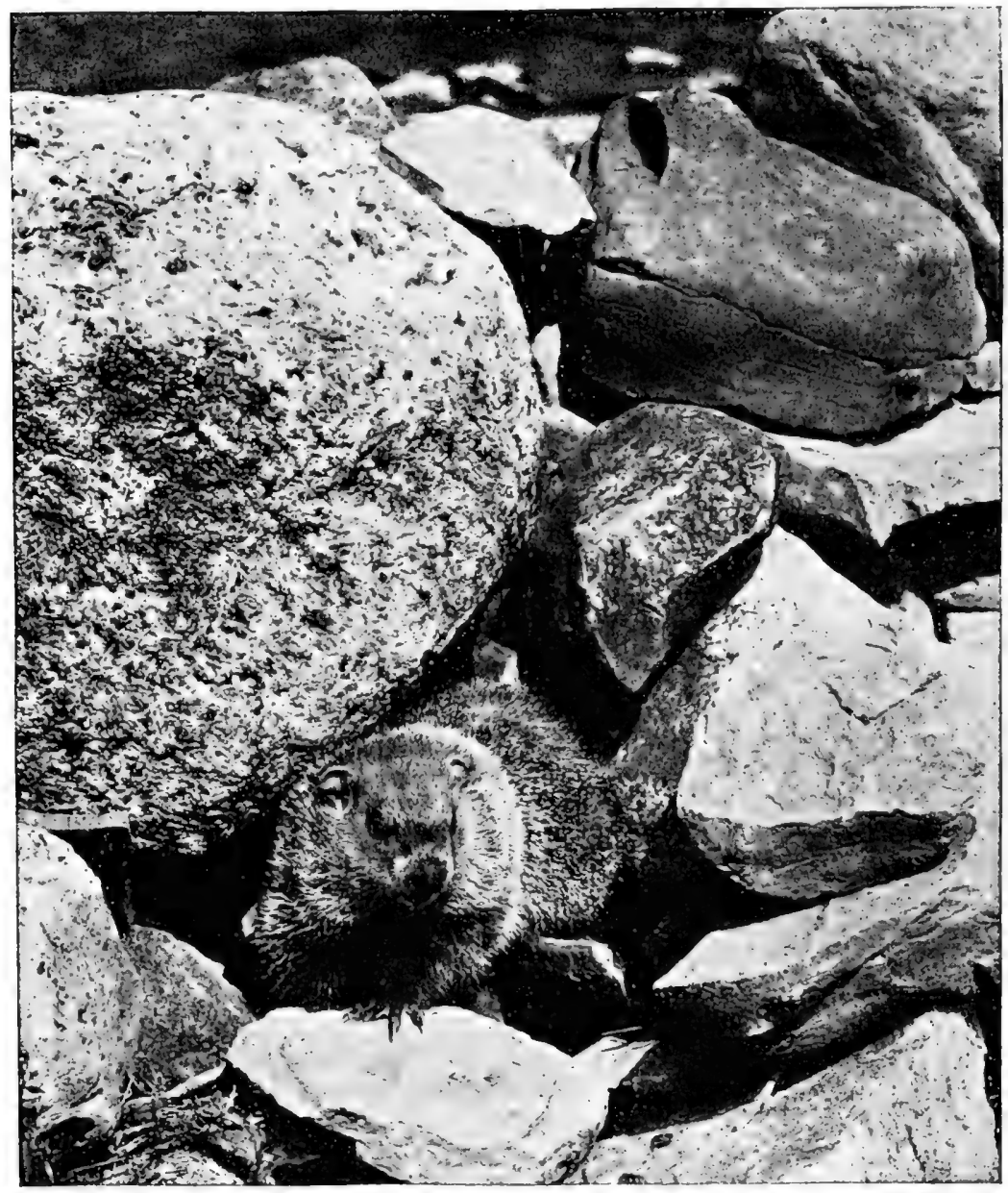

The Summer Home of the Woodchuck

tinual warfare is waged against him; some are trapped, many are shot, and not a few are destroyed by the farm dogs. 
The trap is set at the entrance of the burrow, being made fast to a stake which is driven into the ground. Woodchucks are more easily trapped in May or June than later in the season, for during the former months they are much oftener out in the open. The old ones frequently become very shy, especially those living in meadows remote from the house, and having their burrows in the edge of the woods. Sometimes one of these woodchucks will spring a trap day after day without being caught, or even dig around the trap, much to the disgust of the farmer boy, who is usually paid a bounty of ten cents for each "chuck" caught.

After the grass has been mown the woodchucks become much wilder, and it is at this time that the "village sportsmen" betake themselves into the country on leisure afternoons to indulge in the pastime of shooting them.

The farm dog occasionally develops great ability in the capture of woodchucks. A certain old dog by the name of "Shep," which belonged to a New York State farmer, was a famous woodchuck hunter. After locating a woodchuck, Shep would watch his movements for a little time, then, while the woodchuck was feeding, she would move directly toward him. Keeping her body close to the ground she would 
stop instantly and lie very still whenever the woodchuck raised himself on his haunches to look about for danger. When Shep believed herself to be near enough to the entrance of the burrow she would make a dash for it. If she reached it first, there was sure to be one woodchuck less to nibble the fragrant clover.

No animal exerts less energy in the course of a year than does the woodchuck. He feeds upon the best in the meadow and occasionally the garden, being particularly fond of the juicy peas and beans and tender lettuce. Then as winter comes on forgetting all care and worry he crawls into his burrow and, like the bear, falls asleep, not to awaken until the warm spring sunshine has touched with caressing fingers the slumbering world of nature.

Some years ago while returning from the mill-pond where I had been fishing through the ice for pickerel, I came upon a man in the open field digging for a skunk, which he had tracked into what seemed to be a woodchuck's burrow. As the man was evidently very near his game I waited to learn the result. The burrow branched, and following one of the branches the man came upon a little ball of fur, not the skunk he was after, but a woodchuck fast asleep. He was given to me and I took him home. When warmed 


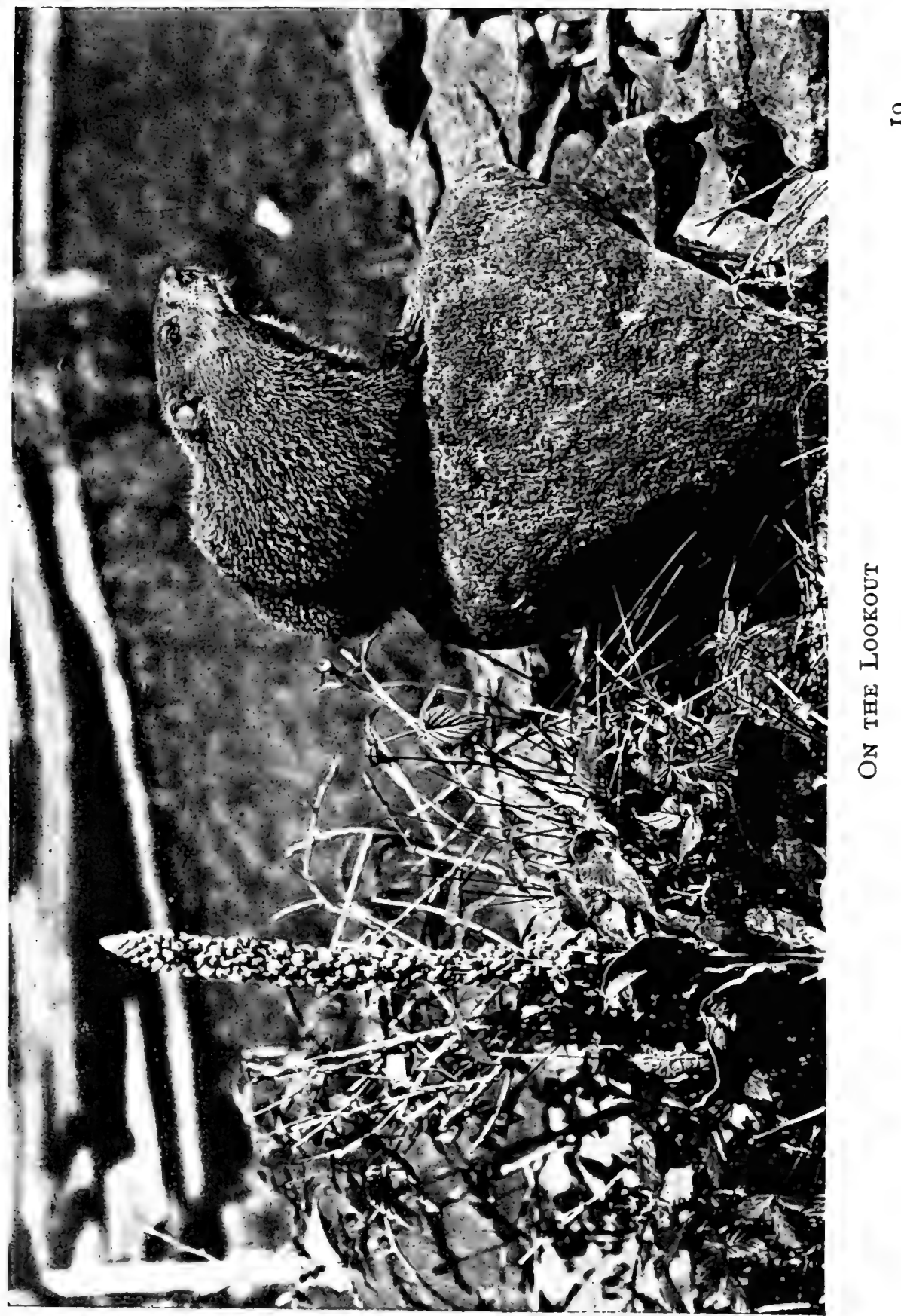


1. 
he slowly awoke, but soon fell asleep again because Nature called for a longer nap.

Let us select a representative woodchuck family and follow in a general way its career, from the time the young are born until they are safely settled in homes of their own. The cubs usually number four or five, and the date of their birth is not far from the tenth of May. The snug little chamber in which they are born is located two or three feet under the ground and contains a small cozy bed of dry grass gathered the previous fall.

By the old rail fence just back of the orchard on my father's farm lived a woodchuck family. The mother introduced herself one bright warm morning in the latter part of May, just as old Rover and I were starting out for a day's fishing. The shrill whistle she gave was enough of a challenge for any boy and dog. So off we started full tilt in the direction of the sound. Of course Rover arrived first on the scene of action, and when I got there he stood thrusting his nose in at the entrance of the burrow, wagging his tail vigorously and giving utterance to the short quick yelps so characteristic of a shepherd dog. The burrow gave evidence of constant use, and for a moment my attention was divided between the interests of hunting and fishing. However, as my game 
was in a convenient spot I decided to leave it for some future day's sport and make sure of the fish. It was not so easy to bring Rover to my way of thinking, but I finally coaxed him away from the fascinating spot.

Fascinating indeed it surely proved to be to me, and more than one day's sport I got out of that little burrow. I took care, however, that Rover didn't go with me when I made my visits and, instead of digging out the inmates boy-fashion, I waited for them to come out of their own accord. Several times the old woodchuck appeared, but feeling sure that there were "more to follow," I patiently watched and waited. Finally my patience was rewarded; for one fine morning five little cubs came tumbling after their mother along the narrow passage to the entrance of the burrow, where they looked with their great beautiful brown eyes upon the strange outside world. What a marvelous surprise it must have been to them to view the green grass and the beautiful flowers! The breeze brought to their dilated nostrils sweet odors from the meadows, while a great burst of music saluted their ears, which were now really open for the first time. The wrens were singing in the old apple tree; the bobolinks were "running down" their "brooks of laughter" through the air; the 


\section{The Woodchuck}

meadow larks were whistling on all sides, while myriads of insects added their murmuring music to the general symphony.

The mother knew that all of these sounds were only a part of her world and meant no harm, but she listened very attentively for any unusual sound be-

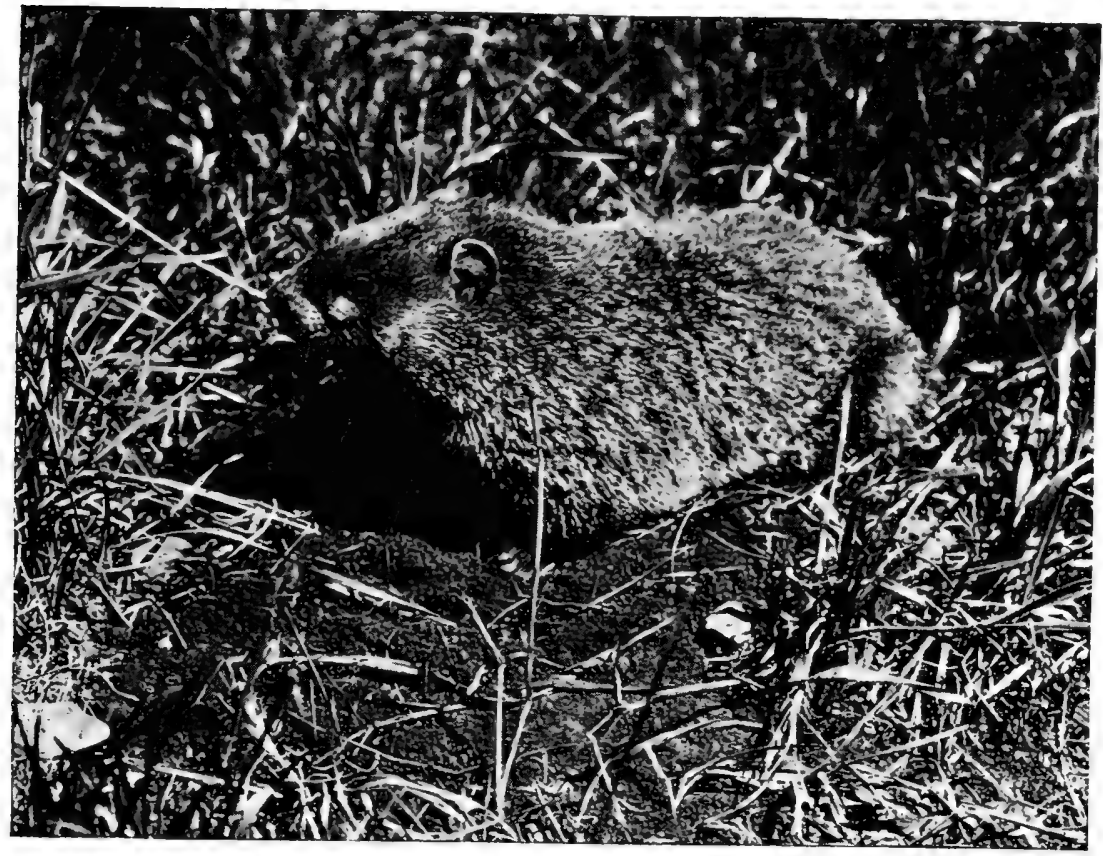

The Mother Listening for Unusual Sounds

fore she ventured from the entrance. When satisfied that there was no danger lurking in the fair clover fields or in the blossoming apple trees above, she led the way into the grass, followed by her little brood, which tumbled frantically along in their haste to 
keep close to her. They tried to imitate her in everything, and when she nibbled a clover leaf they followed her example, and soon the sharp little teeth had learned to cut the juicy leaves.

The real object of their first outing, that of filling their little stomachs, was soon accomplished, and then they began playing about in the grass very much like puppies; but the watchful mother was careful not to let them wander far from the entrance of their home. Suddenly her trained ear caught the sound of something approaching and she lost no time in hustling the little ones into the burrow, for it might be old Rover racing across the meadow, and possibly he would turn their way or wind them if he came close. Sure enough! they were scarcely safe when the dog appeared in full sight over a knoll, making straight for them! The cubs could have traveled only a part of the tunnel before they heard the deep breathing of the dog at the mouth of the burrow. The exertion and the excitement must have made their tiny hearts beat fast, as for the first time in their lives they learned what it is to be frightened.

This was only the beginning of their education, for day after day they came out of their burrow and when they scrambled back, something had been added to their little stock of woodchuck knowledge. 


\section{The Woodchuck}

A part of this wisdom came through copying their mother, but by far the greater part came through instinct and through experiences of their own. They learned which grass was good for food, which for medicine, and which was not to be touched at all.

Some attention was given to the art of climbing, for from elevated positions they could command as much more extended view of meadow and woodland-yes, woodchucks really climb fences and small trees! and I found it extremely entertaining to watch their clumsy first attempts. This lesson in climbing, however, might sometimes be omitted, but never a day passed that the little woodchucks did not receive a lesson in danger signals. They soon learned to distinguish, among the many sounds that came to their ears, those that threatened harm and danger from those that meant no harm at all. Although Bob from the next farm nearly caught one of the little fellows, they learned that a dog was not a very dangerous foe, as his presence was usually made known while he was some distance off; but when a fox was in the vicinity-then was the time to be wary indeed!

By the middle of August the little cubs were pretty nearly grown-up woodchucks, and the time was fast approaching when the frolicsome days of babyhood 
would be over and they would have to settle down to the serious business of life, either finding a deserted burrow or digging one for themselves. It would have been interesting could I have watched the separation of this family and have known all the circumstances leading up to it, but they "stole a march" on me, and within a space of three days the old burrow had but one occupant, the mother.

Usually each woodchuck has a burrow by itself, but occasionally a pair will live together through the winter. Early in autumn I came upon such a pair not far from the summer home which had so interested me, and I pleased myself by imagining they were two of my old friends. The spot they had selected for their burrow was on a gentle sunny slope in one corner of the meadow. They had evidently been working, little by little, on the new burrow before they left the old one, but now they made a regular business of it and worked with a will. And rapid progress they made, for their feet are armed with powerful claws and there is a partial web between the toes, a combination which makes a most excellent pick and shovel. The fore feet are used principally for digging and the hind ones for throwing backward the loosened earth and stones.

For some distance from the entrance the burrow 


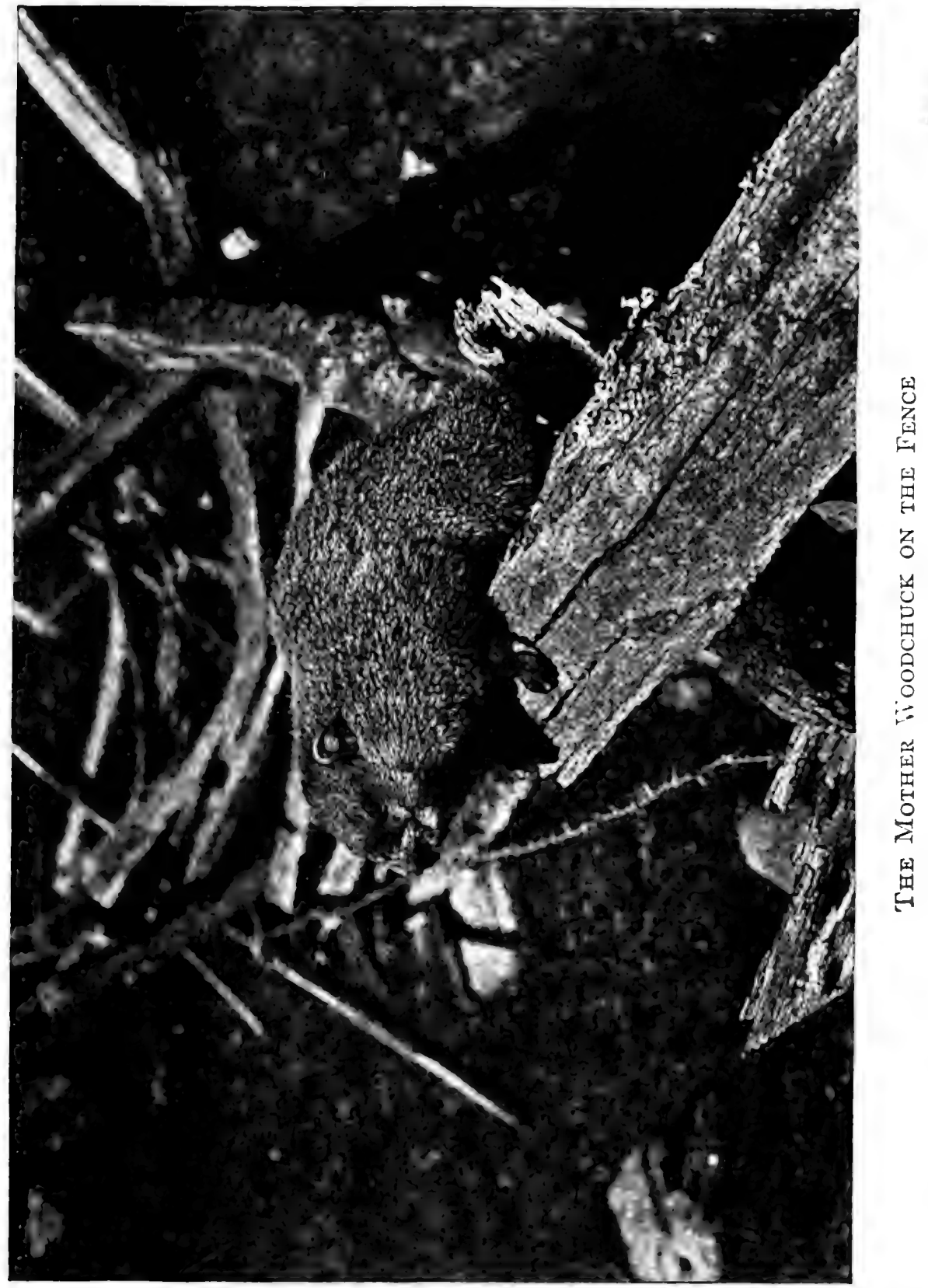




\section{The Woodchuck}

inclined downward quite sharply, then turned slightly upward and continued along beneath the surface for a distance of fifteen feet; this arrangement secured good drainage, which is all-important in the home of the woodchuck. There was a small side tunnel four feet long which ended in an exit, while the main burrow terminated in a chamber of considerable size, in which there was a quantity of fine grass for bedding.

When the woodchucks had completed their home they were ready for housekeeping. The meadows had been mown and a tempting new clover crop was spread before them. There was nothing to do now save to eat, bask in the golden autumn sunshine, and eat again. With a few weeks of this sort of life there came a wonderful change in their appearance; their cheeks were distended, their fur glossy, and their skins stretched with fatness.

When September was well advanced, they could cat no more, and had only to wait and doze away the time until about the first week in October, when Mother Nature would put them sound asleep. The blood began to flow more slowly through their veins, a sleep crept gradually over them which they could not resist, and finally, side by side in their snug retreat, they curled themselves into balls of fur, and fell asleep.

Warm summer days followed with their mellow light; 
Indian summer came and went, but the slumber of the woodchucks was unbroken; and thus the cold cheerless winter passed in one long dream of summer.

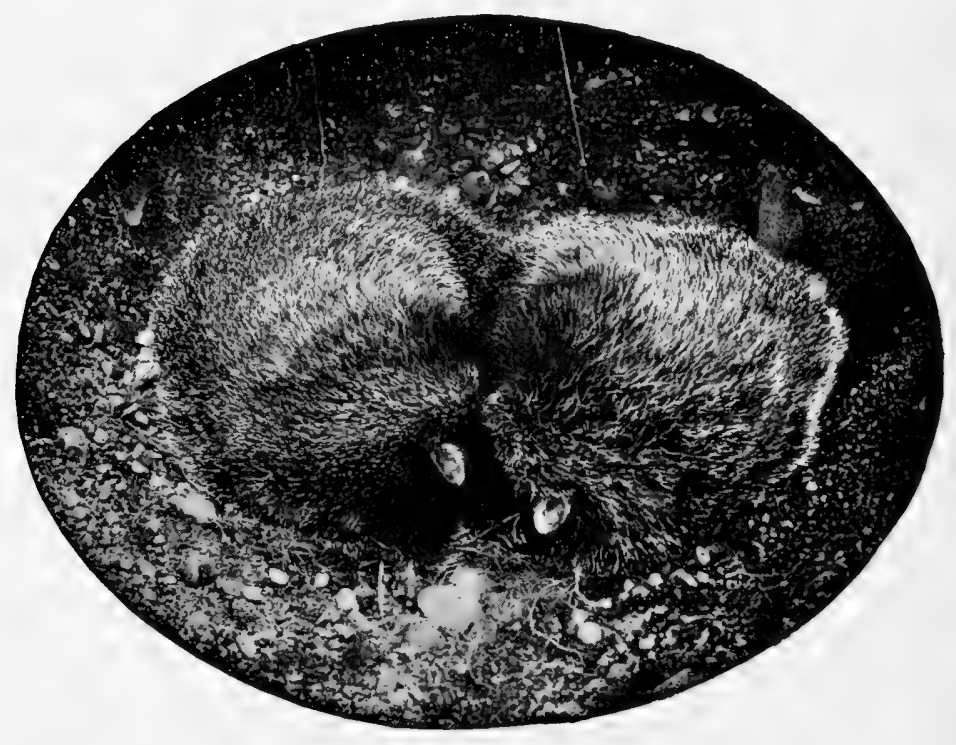

They Fell Asleep 


\section{THE SKUNK}

E $T$ is in the rural districts throughout the greater part of North America that the skunk is best known; but being a wanderer of the night, he is not so familiar a sight as is the squirrel or the woodchuck. In respect to his nocturnal habits he holds the same relation to the mammals that the hawks and owls do to the birds.

$\mathrm{He}$ is known in different localities by various names, such as polecat, essence-pedlar, and wood-pussy. "Wood-pussy" is pretty and probably derives its origin from the fact that after twilight the skunk may be casily mistaken by the uninitiated for a cat. The skunk is about the size of the cat, with long fur and a very bushy tail, the prevailing color being black and white. The black fur is the more valuable, but the coloring of fur is now so largely practised that it matters little how much white there is, for the skins all go through a dark dye to make them uniform in color. After dyeing, cutting, and making, few suspect that the fashionable "Alaska Sable" furs of the 


\section{$3^{2}$

city belle come from the little bicolored animals called "wood-pussies" by the country folk.

Whether one comes upon the skunk by day or by night he seems never to be in any haste to conceal himself. Such implicit confidence has he in his ability to defend himself that he treads the forest

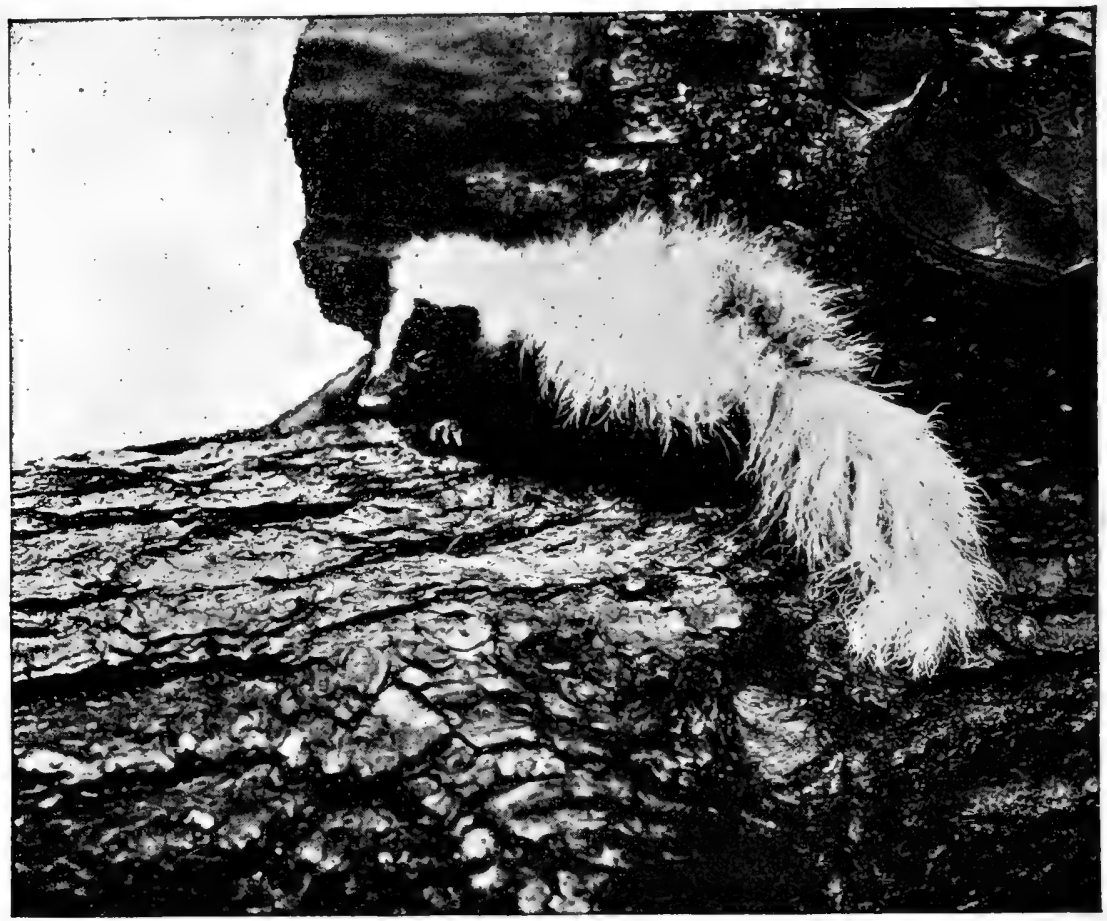

The Skunk

as boldly as though he were lord of all he surveys, showing a lofty indifference to the presence of man and beast. He protects himself by spraying the enemy with a musky secretion having a most powerful 


\section{The Skunk}

and disagreeable odor. This secretion is stored in two glands located under the tail, and may be ejected, by muscular contraction, to the distance of about ten feet. The contents of the glands are discharged, probably one or both at a time, as the occasion demands, in the form of a very fine spray. In addition to its terrible odor, this liquid is so intensely acid that it burns the skin like fire. In extreme cases such a discharge has been known to produce blindness. When the skunk is facing you there is no danger that he will discharge his artillery; it is only when he turns tail toward the enemy that there need be alarm. Many believe that the skunk scatters the essence with his tail, but this is entirely incorrect, for the skunk is a very cleanly animal, and during the discharge the tail is arched high above the back to keep it undefiled. If he were to wet his tail with the essence he would attract many enemies in the vicinity, and without doubt it is a matter of both prudence and comfort for him to remain free from the stench.

The Indians of the upper Columbia Valley have a quaint legend concerning the origin of this peculiar weapon of the skunk. According to the reports of the War Department, in this particular part of the river there are many rocks of fantastic forms. On the top of one of these the following incident occurred: 


\section{4

"In the long ago, a skunk, a coyote, and a rattlesnake each had a farm on the top of the Whitestone. Those were the days before the skunk was as odoros as he is now, and he was esteemed a good fellow and pleasant companion by the other animals. As in other small communities, jealousies, dissensions, and intrigues arose. The result was that the coyote and the rattlesnake took a mean advantage of the skunk, and one night, when he was asleep, threw him off the rock, away down into the river. He was not drowned however, but floated on and on, far away to the south and west, until he came to the mouth of the river where lived a great medicine-man and magician. To him the skunk applied for means of revenge, and was fitted out with an apparatus warranted to give him immunity from, and conquest over, his enemies. Back he journeyed along the river to his old home, where he arrived safely, much to the surprise of the coyote and the rattlesnake. So unpleasant did he make it for them, with the pungent burning liquid, the gift of the magician, that they soon left him in undisturbed possession of his rocky home."

The self-confidence of the skunk sometimes causes him to become quite aggressive upon a slight pretext. John Burroughs, the naturalist, told me of an incident of this kind which happened to him a few years ago 


\section{The Skunk}

while on his way to "Slabsides" one morning. Said Mr. Burroughs: "I was on my way up the hill when I saw a skunk slowly coming toward me, and I thought, now I will have some fun with that skunk. I collected a few stones and as he approached hurled two or three toward him, but he seemed not to heed them in the least. By this time he was coming quite rapidly for a skunk, and waving his tail from side to side as much as to say, 'Two can play at this game.' He was dangerously near. I had not only to give him the right of way, but he actually followed me for a short distance."

I once had a similar meeting with a skunk. It was near sunset, as I was passing along the foot of Hall's Hill in the town of Columbus, New York State, when I discovered the partially bleached skeleton of a cow near some bushes. Evidently the carcass had been left there late in the winter or early spring. This attraction, together with the surroundings, offered an ideal situation for skunks. About one hundred feet from the carcass, and extending up the hill, was a fence the greater part of which was heavily fringed with bushes. I entered the bushes quietly and saw, about thirty feet away, what appeared to be a woodchuck's burrow. I was about to step forward, when a full-grown skunk emerged from the burrow and began 
smelling about on the ground, occasionally pawing among the dried leaves. He gradually ascended the hill, but remained under cover of the bushes. When the skunk was about fifteen feet from his burrow I rattled a dry bush, but otherwise remained quiet and motionless, whereupon he turned and stamped the ground with his fore feet. In a moment he continued on his way, and again I moved the bush and stepped forward a pace. The skunk turned and came directly toward me, and I thought he was going to enter the burrow, but as he did not, I immediately sought the meadow beyond. He followed me into the clearing, twice uttering a little grunt, and as many times threatening to spray me with his essence. $\mathrm{He}$ soon gave up the chase, however, returning to the bushes, where he was gradually lost to sight in the coming darkness.

The den of the skunk is usually a deserted woodchuck burrow, but occasionally in the summer-time he uses a hollow $\log$ or crevice in the rock. It is not to be inferred, however, that he is lacking in ability to dig a burrow; quite the reverse. He can dig rapidly in the solid soil, and in newly ploughed fields will worm himself through the loose earth like a mole. At times the rapidity with which he conceals himself in this way is most surprising, and probably by this 


\section{The Skunk}

means he often succeeds in evading his worst enemies, dog and man. One day I came upon a skunk in a ploughed field. He at once began to burrow into the soil, and in three minutes, was out of sight; later he emerged some fifteen feet from the spot where he had disappeared.

Contrary to what we should expect, the burrow of the skunk is usually free from the odor of the essence, particularly when the young are helpless. The natural odor of the body, also, is far less noticeable than that of either the woodchuck or the opossum. The abode is frequently changed, but is usually located near the edge of the woods. As cold weather approaches these changes become less frequent, especially with the old skunks, and they settle upon a permanent abode to which, in preparation for winter hibernation, they carry for a bed quite a quantity of dried grass and leaves.

This "holing up," or hibernation, becomes more marked as we go farther north, the degree of hibernation corresponding with the severity of the winter. The period of inactivity is broken several times during the season, when the weather becomes mild for two or three days at a time. Such times are known among the trappers as a "skunk-run," and are likely to occur during January thaws, and 
for this reason the January moon is called the "skunkmoon."

Late in the fall and to some extent through the wirter, it is the habit of the younger skunks to congregate in one den, sometimes to the number of six. The trappers take advantage of this and often very easily secure several at a time. The manner of capture is something like this: It is mid-January and for two days the weather has been mild. The morning of the third day is still warmer and a trapper remarks, "Skunks must have run last night." He now remembers the bait left some time ago in a piece of woods well designed to harbor skunks. He revisits the place with traps and a small axe, and finds in the soft snow numerous lines of tracks, leading, singly in most cases, in every direction. One of these he follows, and within a quarter of a mile it terminates at the entrance of a burrow. But this is not the only track which ends here; there are at least three others of the same kind. Four deadfalls are set near by and baited with fresh meat, while in the entrance of the burrow a trap is fixed. At three other burrows deadfalls and traps are set in a similar manner. If the weather continues warm, each trap must be visited early the next morning, for if caught, the skunk is likely to make his escape by amputating its leg. 
Skunks are more easily trapped than most animals and the generation of to-day seems to be no wiser in the matter of snares than they were in the days of our forefathers.

The trail of the skunk is sharply defined and consists of what appears to be two single trails close to each other, something like this. $\circ \circ \circ \circ \circ \circ \circ \circ \circ$

$$
0000000000
$$

The reason for this apparent double trail is found in the fact that the legs of the skunk are so short that they cannot meet under the centre of the body. This also accounts for the rolling sailor gait of the animal. The skunk seems always to be on his "sealegs."

The skunk lives upon animal food, and in his search for it he brings upon his head the wrath of many a farmer. When a wood-pussy takes up his abode under the barn there is sure to be trouble among the fowls, unless they roost high, the greatest loss being liable to occur among the chickens. The mother hen may have a dozen little ones tucked away at night under protecting wings, and before morning a skilful paw may remove half the number, or more, leaving only the slightest traces of their unhappy end. The location of the roosting-place must then be changed, for Mr. Skunk will continue his nightly 
visits until the whole family is devoured. Other domestic fowls suffer in much the same way from such depredations. The ground-nesting birds also pay a heavy tribute, both in eggs and in young, to this robber of the poultry yard.

It would appear at first that the skunk has no redeeming qualities, so far as his bill of fare is concerned, but this is not true. In the destruction of field mice, grasshoppers, and various forms of vermin he is a very valuable animal and one to be protected by the farmer. The favorite food of the skunk, whether wild or in captivity, seems to be the varieties of harmless snakes. A pet skunk, belonging to one of my neighbors, preferred snakes to every other kind of food. When a snake was given him he would rear on his hind legs and dance about, much like an awkward monkey, attempting constantly to grasp the snake by the tail, and when successful he would shake it to death, and then make off with it to his hollow log, there to enjoy his feast undisturbed. Dr. Charles C. Abbott cites the following story: "In June, I863, I witnessed a terrific combat between a large skunk and a black snake, which, I judged, measured fully five feet in length. The prowling skunk had evidently seized the snake by the tail and endeavored to give it a violent shake, 


\section{The Skunk}

as it would a garter-snake. This angered the snake, and, turning like lightning, he wrapped himself about the skunk, completely encircling both neck and body. The head was so far free that the skunk could give the snake nip after nip, though it could not get a strong enough hold to disable it. Rolling over and over, hissing and snapping, the snake nearly concealed by the long hair of the skunk, the two creatures presented a strange spectacle as they struggled, the one to conquer, the other to escape. After watching them for fully five minutes, I ventured to approach, and dealt the two a hard blow with a club, and then ran back a few paces, not knowing what might be the result. Turning about $I$ ventured to return part of the way to see whether the struggle continued. All was comparatively quiet; and coming still nearer I found that the snake had relinquished its hold and was slowly retiring in a disabled condition. The skunk was lying quite motionless, and proved to be dying, though not dead. Soon after I examined the animal carefully and found that it had been strangled or nearly so."

The skunk is particularly valuable in the hopgrowing regions, where he hunts the large grubs so destructive to the hop-roots. On a spring morning as you pass through the hop-yard you may notice 


\section{The Skunk}

numerous holes about the hills. These indicate the industry of the nocturnal visitor.

Young skunks are very interesting, and those I have seen had the habit of stamping the fore feet either while playing among themselves or when excited by a person, continually threatening to spray the subject of their irritation. By a simple surgical operation the muscles which control the scent-bags may be cut, thus removing all danger, although the animal will assume the threatening attitude as before.

If the young are captured while small and constantly handled and petted, they will show a considerable degree of affection and at times are very playful. Dr. C. Hart Merriam tells the following story about one of his pet skunks, "Meph": "His nest was in a box at the foot of the stairs, and before he grew strong enough to climb out by himself, he would, whenever he heard me coming, stand on his hind legs with his paws resting on the edge of the box and beg to be carried up-stairs. If I passed by without appearing to notice him, he invariably became much enraged and chippered away at a great rate, stamping meanwhile most vigorously. During the evening he occasionally assumed a cunning mood, and would steal softly up to my chair, 


\section{The Skunk}

and, standing erect, would claw at my pants once or twice, and then scamper off as fast as his little legs could carry him, evidently anxious to have me give chase. If I refused to follow, he was soon back, ready to try some new scheme to attract my attention." They have no way of expressing their joy like the cat or dog, for the young and old alike are nearly voiceless with the exception of an occasional little squealing or grunting noise.

The young are easily captured in the following manner: At twilight, like the bats, the skunks begin

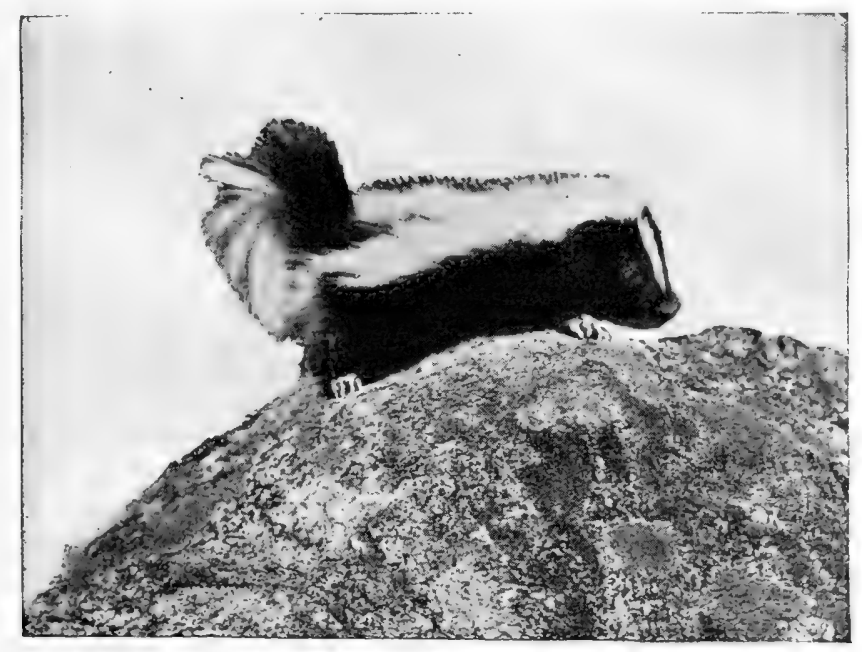

The Rear One of the Line

to move about in search of food. The young when about a quarter grown follow the mother on these nocturnal excursions, and, while moving from place 
to place, they form a line from fifteen to thirty feet long, with the mother in the lead. When a capture is contemplated, the would-be captor takes his place behind the line, and noiselessly approaching the rear skunk, with a quick movement he lifts it from the ground by the tail. This is a nervous moment for the novice, but entirely safe, for when a skunk is thus lifted from the ground, the power of spraying the essence is apparently lost. After the youngster is captured and put in a safe place, the operation is repeated until all the young are taken, the mother continuing on her way, apparently as unconcerned as though she had not lost her family.

It takes a very steady nerve to approach an old skunk and lift it by the tail, and, although I have heard of several instances, I have but once actually seen the feat. This occurred when I was a small boy, in a village where I had gone to get a horse shod. The blacksmith's house and shop stood near each other, and the side door of the shop opened opposite to the outside door of the old-fashioned basement of the house. As it was nearing the noon hour the good wife went to the basement for some potatoes, but scarcely had she entered, when she saw a black and white object in the middle of the floor. The light being dim, its outline was at first 


\section{The Skunk}

indistinct, but as she approached it moved slightly, and she distinguished a wood-pussy. She screamed, dropped her pan and ran into the shop exclaiming, "A skunk! a skunk in the basement!"

The smith, a very self-possessed man, dropped the foot of the horse he was shoeing, and looking at his excited wife said, "Well, Hannah, what of it?"

The answer came promptly, "If you want any potatoes for dinner, you'll have to get them yourself!"

Apparently without concern for his personal safety, or for the danger of defiling the sweet June air, he walked into the basement, quietly lifted the skunk by the tail and brought him forth, and as he threw him over the fence in the rear of the garden remarked, "I never was afraid of skunks, and they do an awful lot of good." 


\section{THE RACCOON}
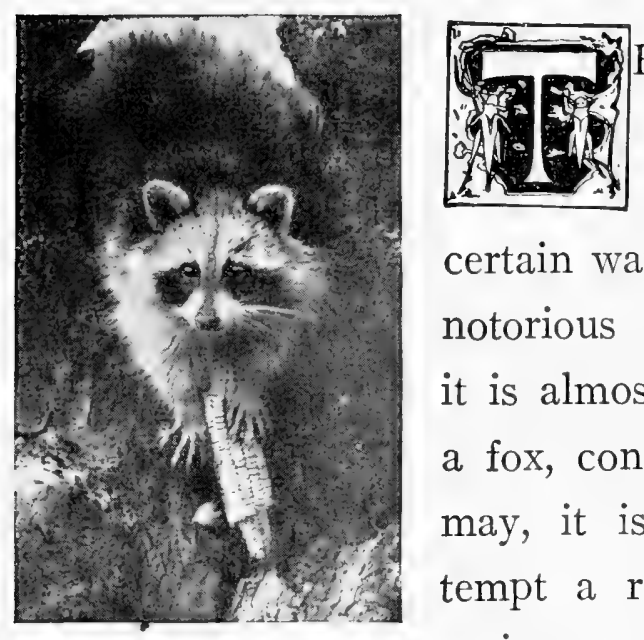

HE raccoon, although not cunning like the fox, is clever, and in certain ways far superior to the notorious Reynard; but while it is almost impossible to snare a fox, conceal the trap as you may, it is an easy matter to tempt a raccoon into either a spring or a box trap, baited with any of his favorite foods. The raccoon has no idea of self-preservation; nothing appears dangerous to him, and he blunders recklessly on to his own selfdestruction, in very much the same manner as does the opossum. Leave this self same blundering animal alone in a room, however, for fifteen minutes, and he will discover more things than a fox would find if he were left there all day.

In the use of the fore paws the raccoon resembles quite closely the monkey, but on the ground his move- 


\section{The Raccoon}

ments are like those of the bear; while in climbing about in trees his shambling gait disappears, and he becomes at once a graceful animal. He may well be a good climber, for he uses a hollow in a tree for a nest, and many are the trips he makes to and from the ground. Here in this cavity the baby raccoons, varying in number from three to six, are born about the first of April, and they are said to remain with the mother for nearly a year. This nest is their resting-place during the day at all seasons of the year, although they are occasionally found curled up sound asleep in a hollow log or stump. The young grow rapidly, and by the time the field corn is in the milk they have for some time been following the mother on her nightly excursions.

Although the raccoon is usually thought to be nocturnal in habits, I am led to believe that when it is cloudy he roams about quite freely in the daytime. This habit of roving around at night seems to apply more particularly to wild raccoons than to tame ones, two tame ones that I have in mind being abroad several hours of each day.

Observers have very generally stated that the raccoon hibernates more or less, according to the severity of the winter; nevertheless, I believe that cold weather does not affect him so much as the 
deep snow, to avoid which is his real reason for staying at home. I will give one fact that leads me to form this conclusion. It is this: If an icy crust is formed, the raccoon is ready to scurry about, no matter how deep the snow or how long the winter. The degree of hibernation of the raccoon and that of the woodchuck bear no resemblance to each other; for the woodchuck if taken from his burrow during his long sleep is awakened with the greatest difficulty, while the raccoon becomes "spry" with very little urging.

In the spring the raccoon is greatly reduced in flesh, as John Burroughs says: "In March, that brief summary of a bear, the raccoon comes out of his den in the ledges and leaves his sharp digitigrade track upon the snow,-travelling not unfrequently in pairs, - a lean, hungry couple, bent on pillage and plunder. They have an unenviable time of it,-feasting in summer and fall, hibernating in winter, and starving in spring. In April I have found the young of the previous year creeping about the fields, so reduced by starvation as to be quite helpless, and offering no resistance to my taking them up by the tail and carrying them home."

After hibernation the old raccoons are not, as a rule, so much reduced in flesh as the younger ones, 


\section{The Raccoon}

but they are ever ready for a "square meal," their hunger driving them sometimes to farm buildings in search of food. One morning a friend of mine found a raccoon in his woodshed feeding upon a chicken that had been killed the night before.

Long and varied is the menu of the raccoon, consisting in part of nuts, frogs, fish, mollusks, turtles, poultry, and corn; but corn in the milk is the food most sought after-the season of young corn is the "watermelon" time for 'coons both old and young.

These prowlers of the night are also exceedingly fond of fish and they love to wade in the shallow water along the brooks, rivers, and ponds, overturning stones in search of them. I have often seen their fresh trails in the mud, perhaps two or three going in the same direction, as though they hunted in friendly companies. Fish sometimes venture into shallow water, and then must the raccoon make the most of his opportunity; for he cannot, like the otter, pursue the fish under water. His ability to catch fish depends largely upon the dexterous use of his fore paws. I have never seen a wild raccoon fishing, but I believe that his method is the following: when a fish ventures into shallow water, within reach of the raccoon, the paw is used like a scoop and the haul is 
made. My belief is drawn from observation of a few tame raccoons and of some others not so tame. Water was put into a pan to the depth of about four inches, then two or three small fish were dropped in. When the pan was placed upon the floor, Jim, our pet raccoon, was allowed to enter the room, and, as usual, he at once began his tour of investigation. Jim soon discovered the pan. He was a young raccoon, and to my knowledge had never seen a fish before, and had never even been mussel hunting. Walking about the pan he watched the fishes very carefully for a minute or more, but since no advantage could be gained by this procedure, he sat down and, putting one paw upon the edge of the pan, tried to grab the fish with the other, but did not succeed. This lack of success seemed only to spur him on to greater enthusiasm; his next attempt being to grasp a fish with both paws, but the fish slipped away; then he used one paw as a scoop and triumphantly landed a fish, which he at once devoured. Returning for the second, he landed it in the same manner as before. After this he always used this effective method of angling.

A few years later I had an opportunity to experiment in the fishing way with another pet raccoon. One of our neighbors caught an old raccoon, and 


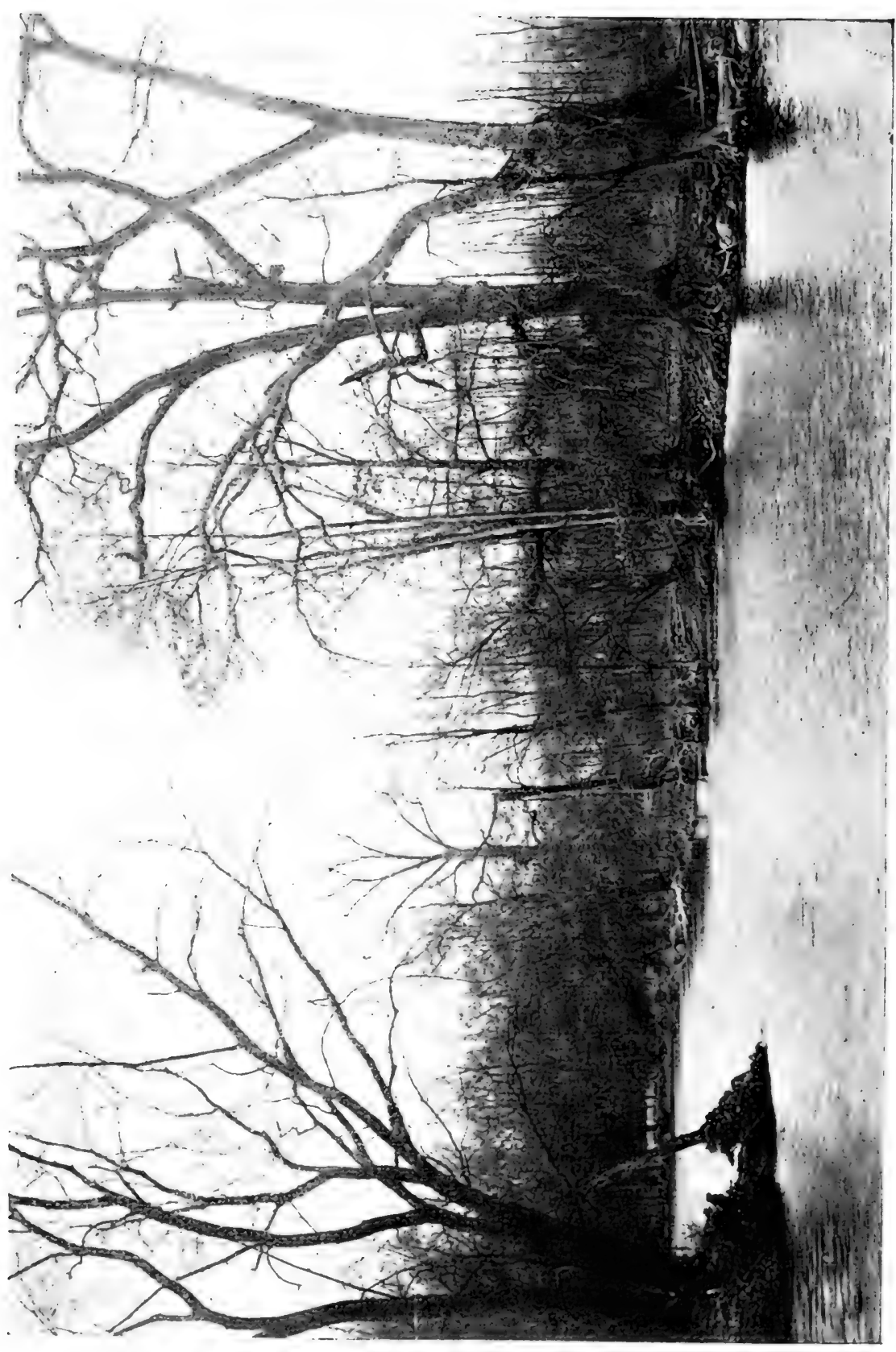

u

ن 


\section{The Raccoon}

the veteran fished with his paws in the same manner as did our pet Jim.

But though the raccoon may enjoy fishing, his festival season is when the corn is in the milk. It is this fondness for the corn that has brought down upon his luckless head the vengeance of the farmer. When a cornfield has been located by the raccoons they visit it nightly, whether in bright moonlight or in the drizzling rain, until the corn is well hardened. Most expert are they in stripping the husks from the ear, using their fore paws as we use our hands.

In the green-corn season I have often heard what I supposed to be the call of the raccoon, perhaps a summons to meet at some common place of feasting. This vibratory cry seemed to pierce the thick gloom as it came from the forest, field, or near by orchard, the rallying-call gradually lessening as the various clans met; and when it entirely ceased we imagined that they were busy stripping the husks from the newly formed ears.

Raccoon-hunting by the light of the August moon has furnished as much sport in the North as has opossum-hunting in the South, although raccoonhunting is not restricted to the North, as many a colored man can testify. The flesh of the young raccoon is toothsome and not by any means to be 


\section{$54 \quad$ The Raccoon}

decpised, but the muscles of the old ones are too highly flavored and deciderlly tough.

But life is not all freedom and feasting for the raccoon. Not even when the corn is in the milk; for then the hunting season is at its height. Raccoonhunting is one of the American sports in which there is little dignity. In fact I never attended such a hunt where there was any pretence of anything other than confusion; and from what I have heard the conditions must be very similar to those of the opossumhunt in the South. But in reality it is a scrious matter to prepare for a raccoon-hint; for your passage through the wet corn, the race across the stubble-field, through briers and thicket, contact with the barbedwire fence, which you did not see in time,-all these factors work toward reducing your clothing to mere threads. The light unto your feet while you were running came from a lantern carried by a friend, and, as fate would have it, his body was often between you and the light just when you most needed illumination. Anong the numerous pitfalls are the hollows that are so often filled with water. Both man and dog are liable to get a good ducking, which is of course only one of the many incidents of raccoon-hunting.

The real old-fashioned raccoon-hunt is not a select affair; it embraces the neighborhood. Nothing is 


\section{The Raccoon}

definite except the date and place of meeting. These being settled, the hunters begin to collect about nine o'clock in the evening, the boys of course a little earlier. With each is a dog, but as for guns, there will be four or five old ones in the party, ordinarily of the Springfield type, and warranted to kill a 'coon from either end! You need not possess a wonderful imagination to picture vividly the scene before starting. The boys, always the forerunners of the gathering pandemonium, have early in the evening located the harvest apple trees, and by the time the men assemble, bringing more dogs, things are in a state of w.ld excitement. The men are quiet enough, smoking their pipes, telling stories, and talking over the possibilities of the hunt, but the dogs, away from lome once a year perhaps, are like so many boys until they find out "who is who." There are in consequence several promiscuous contests. Thcre may be two or three dogs out of the number that can follow a trail fairly well, and the rest will keep with these.

By midnight, the raccoons being at their feast, the hunting party proceeds in none too quiet a manner to the cornfield. Soon, joined by the other dogs, the trailers are in hot pursuit, the enthusiasm of the younger hunters breaking forth in shouts, as they follow 


\section{${ }_{5}^{6} \quad$ The Raccoon}

the rapid pace set by the raccoon. He is passing over swampy ground, and the pursuers have naturally formed into a long line, according to speed. Through the fatigue of the chase, the noise grows less, and the raccoon, also becoming tired, takes to a tree. This fact is loudly heralded by the foremost dogs, and the others join in the noisy proclamation as fast as they arrive; later the bedrabbled hunters surround the tree in which the luckless raccoon has taken refuge. If there is no hollow in the tree, the raccoon is generally found resting upon a limb near the top.

Various methods for bringing down the beast are now discussed: the tree may be cut down; a large fire may be kindled, lighting the tree top so that the raccoon may be shot; one of the hunters may remain on guard until daylight; or some youth may climb the tree and shake him down! Already a youth is clamoring for this questionable honor. $\mathrm{He}$ ascends, and finding the limb upon which the creature is quietly resting, he calls to his companions to be ready to despatch the raccoon, for he is about to shake him loose. He, however, has misjudged the little animal seated upon the other end of the limb; for there is about as much use in trying to shake a raccoon from the limb as there would be in 


\section{The Raccoon}

trying to shake off the bark itself. Some of his older companions, who in times past have tried it themselves, are calling to him that they are ready and waiting to "despatch that 'coon." After trying to achieve the impossible, the boy descends amid the good-humored jeers of his companions, and ever after, any gymnastic effort that he attempts is greeted with "He is the fellow who tried to shake down a raccoon!"

After the fun, the usual move is to fell the tree, and if the raccoon is not stunned by the fall, which seldom happens, there ensues a smart skirmish between it and the dogs. The dogs rushing pellmell upon the prostrate animal; but they, too, have mistaken the ability of the raccoon, and with many howls they rapidly and ignominiously retreat. After the first onslaught the dogs have more respect for the fighting ability of the raccoon, which, by the way, is of a very high order. A few years ago a Scotchman living at Exeter, New York State, had a pet raccoon which he had trained to fight dogs, and the raccoon had never lost a battle.

After the raccoon is finally despatched the party either turns to the cornfield for a new start or disbands, according to the lateness of the hour.

There is another phase of hunting the raccoon which is much more dignified and far more system- 


\section{$5^{8} \quad$ The Raccoon}

atic, yielding to the hunter good returns for the amount of energy expended. When the fur of the animal becomes prime, the hunter, equipping himself with a good raccoon dog, a double-barrel shotgun, and a sharp axe, prepares for an all-day stay in the woods where raccoons are supposed to live. The dog strikes a trail and soon arrives at the tree in which the raccoon is, perchance, quietly sleeping. The man follows and fells the tree. As it strikes the ground it sometimes breaks apart, - and instead of one raccoon there may be two or three, and occasionally five or six. If the tree does not break apart, the game must be chopped out. I have known one hunter in a single day to capture eight raccoons by this method.

The young ones are often taken for pets, and I do not know of any pet wild animal that furnishes more amusement than does the raccoon. I have had two at different times, taken from the tree before they were large enough to leave it. In cach case the animal became very tame, and would come when called. But they are something of a disappointment too; for after a year or so when you have really become attached to your pet, he is apt to fall into bad habits, such as catching chickens or destroying hens' eggs, making it necessary to chain him. If you punish him sufficiently to correct his ways, and do 


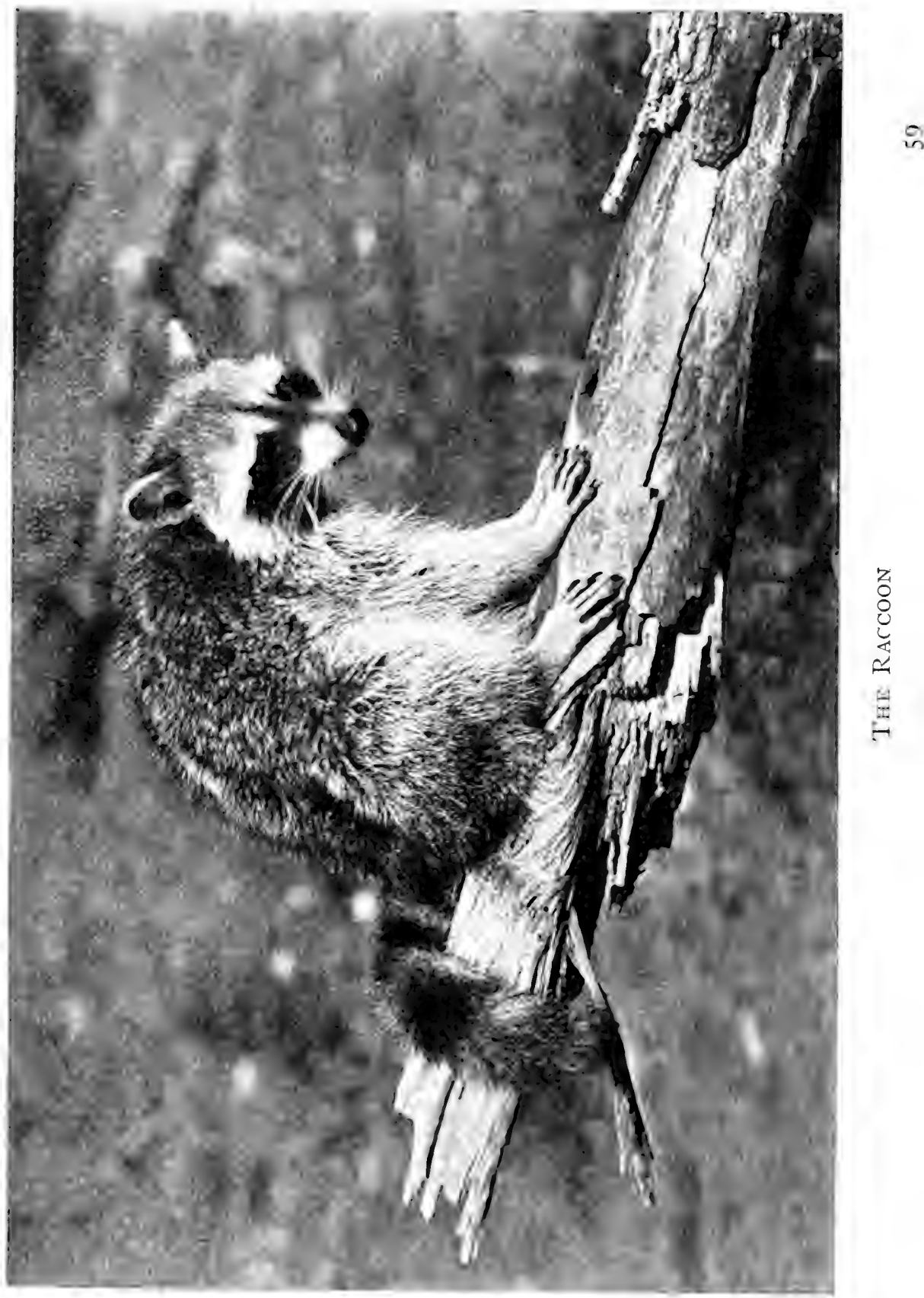




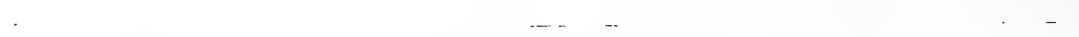


not chain him, he takes to the barn, hiding in the haymow, where you seldom see him. Finally he begins to make nightly excursions; and sooner or later he hears and answers the call of his wild kindred, leaving the haymow nest for the freedom of a hollow in a tree and the companionship of his own kind.

The raccoon shows considerable affection for his master, and his skilful manner in using his paws, and the intelligent expression of his face, endear him to all who make his acquaintance. We sincerely hope that the tracks of this little prowler will long be found about the muddy banks of the old familiar brooks and ponds, and that the quavering voice may still shiver on the August night. Some say that it is the cry of the screech owl and not that of the raccoon; but whether the cry that vibrates through the gloom of grove and orchard be that of owl or raccoon, long may it be before either shall go the way of all wild things! 


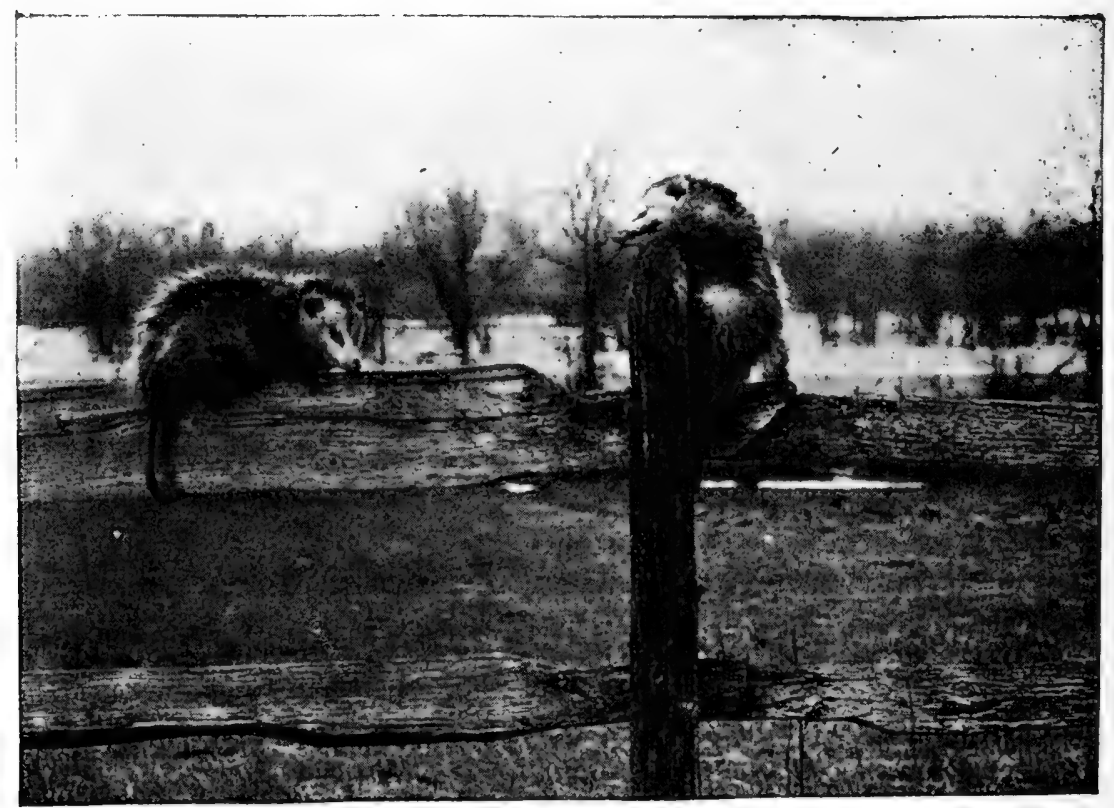

\section{THE OPOSSUM}

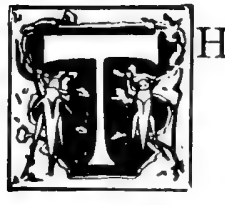

HE opossum is certainly the most distinctive of the North American mammals, inasmuch as it is a marsupial. It seems rather strange that, among so many mammals, the opossum has neither kith nor kin. There was a time when the whole world was inhabited by marsupials, so those living to-day are the separated remnants of that once universal race.

The range of the Virginia opossum is from the latitude of the southern part of New York State and Michigan, southward to Central America. It is very common in the South, and probably there is only one 


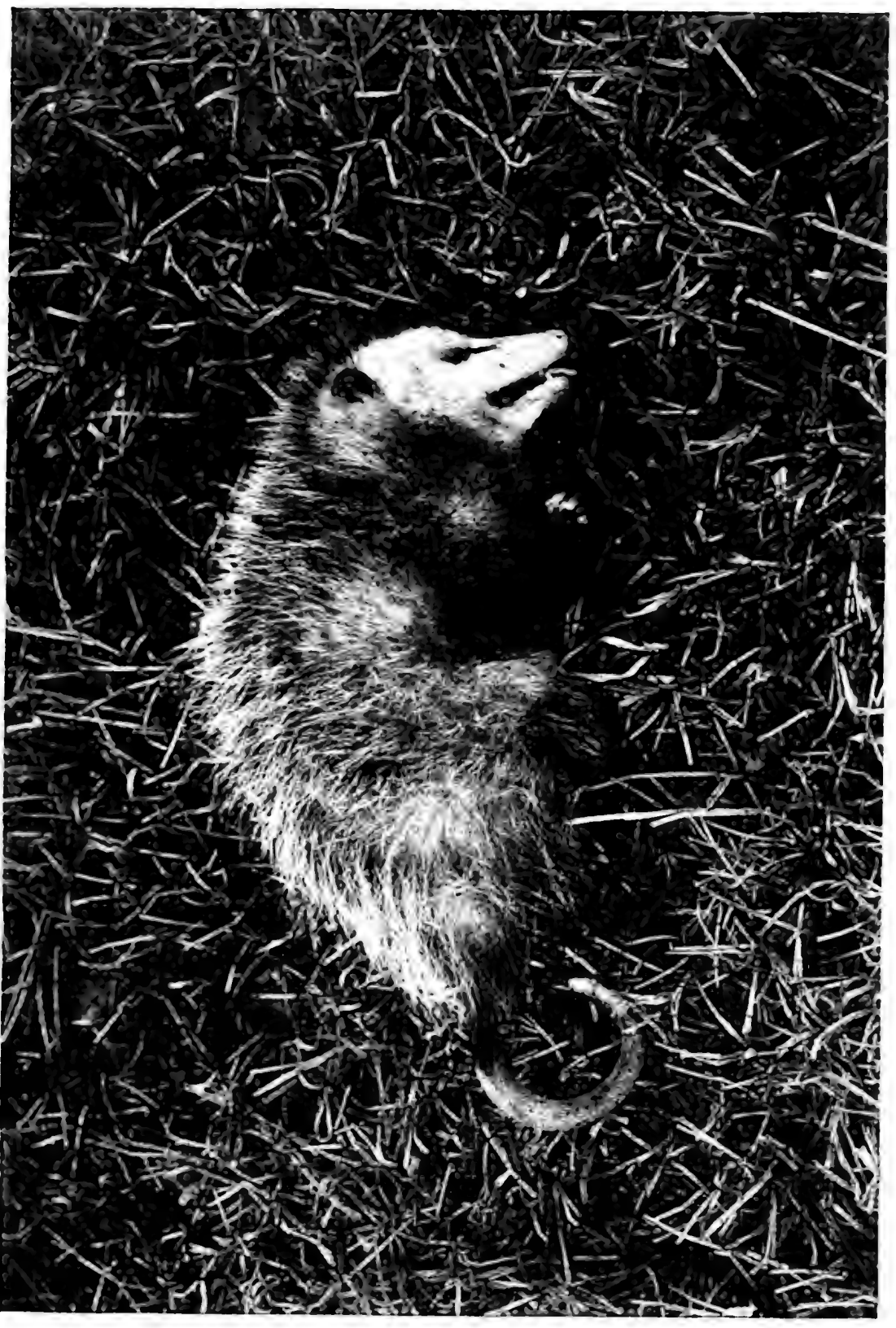





\section{The Opossum}

species, but certainly there is a great diversity among the individuals.

The opossum is about the size of a large cat, its legs are short and its tail is long, scaly, and prehensile; its snout is long and somewhat pig-like, which accounts fur the tremendous width it can open its jaws. The fur is of a general yellowish color, but on the back and sides a greater part of the hairs are tipped with brown or black; intermingled is a liberal amount of pure white hairs. The brain cavity is small, but the senses of sight and smell are well developed.

The opossum, although upon the whole a stupid animal, has one very clever habit, when attacked it simulates death most successfully. At such times the eyes are usually closed, the muscles are rigid, and no amount of rough handling will provoke any signs of life, until an opportunity for escape presents itself, when it will make all the haste of which a slow moving opossum is capable. The most effectual method of reviving the seemingly lifeless animal is to drop it into a pool of water. The shock of this unexpected procedure is apparently too much for it, and it speedily seeks the shore. The immersion usually ends the "playing 'possum," for it will not readily try the stratagem again. This art has probably saved many opossums from destruction by other animals, but the 
"coon" is fully up to the trick, and few deceiving opossums escape him. I have found the ruse of "playing 'possum" to be specific rather than general among the species. Those that are partly tamed seem never to practice it.

The home of the opossum may be in a hollow tree, a crevice in the rocks, or under a building. The hollow tree, however, seems to be preferred. The nest itself is composed of dried grass and leaves.

The opossum usually comes forth from his retreat at the close of day, wandering about in search of food; he is not strictly nocturnal, however, for cloudy days will often find him abroad, and I have seen him in the bright sunshine.

His menu is varied, but you may be sure it is a full one when it can be obtained. It consists chiefly of insects, small reptiles, young birds, and birds' eggs. Occasionally he dines from the poultry yard, and here he shows a decided preference for yourg chickens. Vegetable food enters but little into his bill of fare, although he is very fond of ripe fruits of various kinds.

The young, varying in number from six to twelve, are born in a very immature state-blind, hairless, and exceedingly small, in fact weighing but a few grains. The mother places the young in a pouch, 


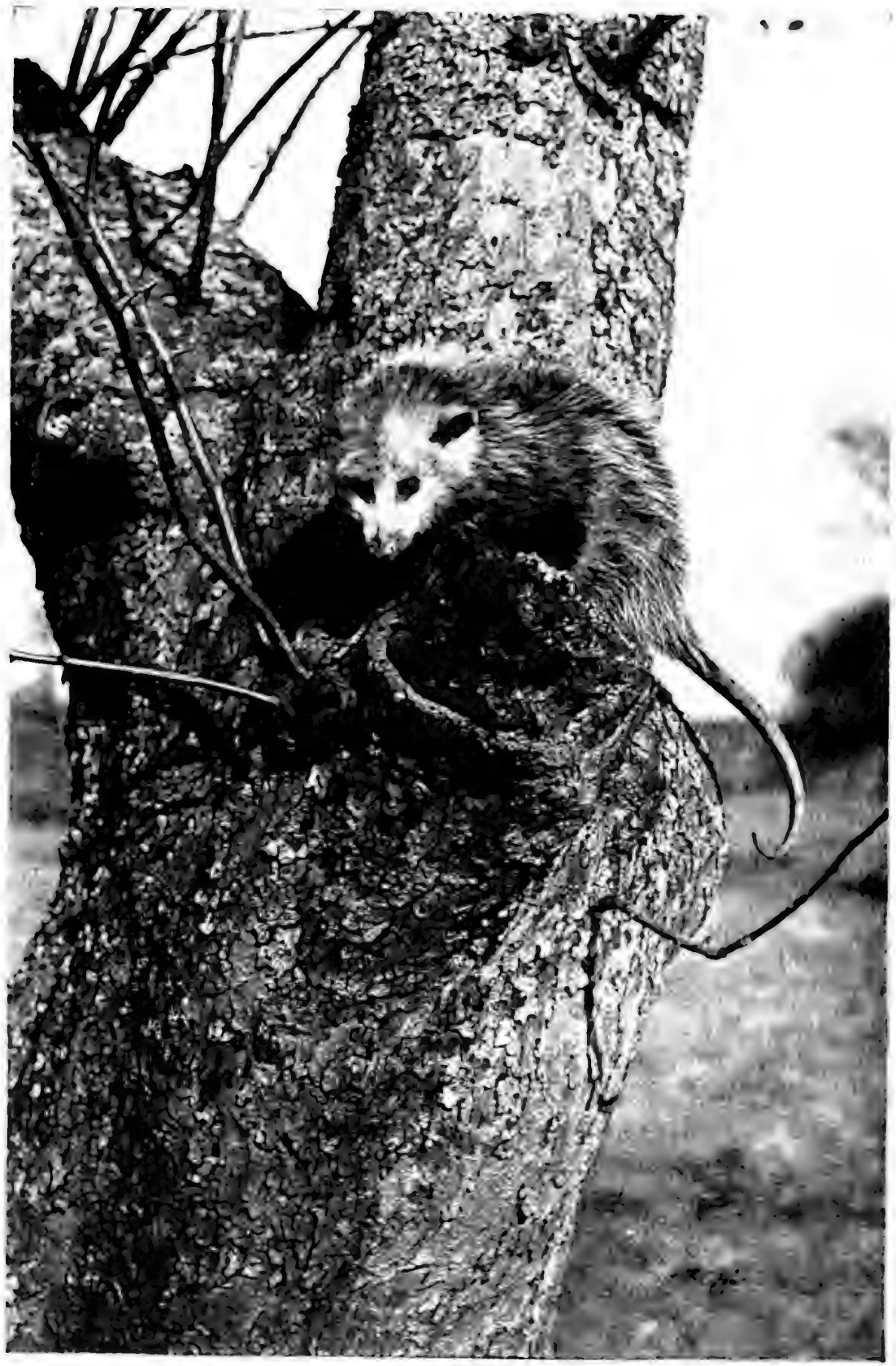

A Characteristic Pose 


\section{The Opossum}

where they are nourished and kept for about six weeks. After this they venture out and climb about over the body of the parent, clinging to her fur. Sometimes

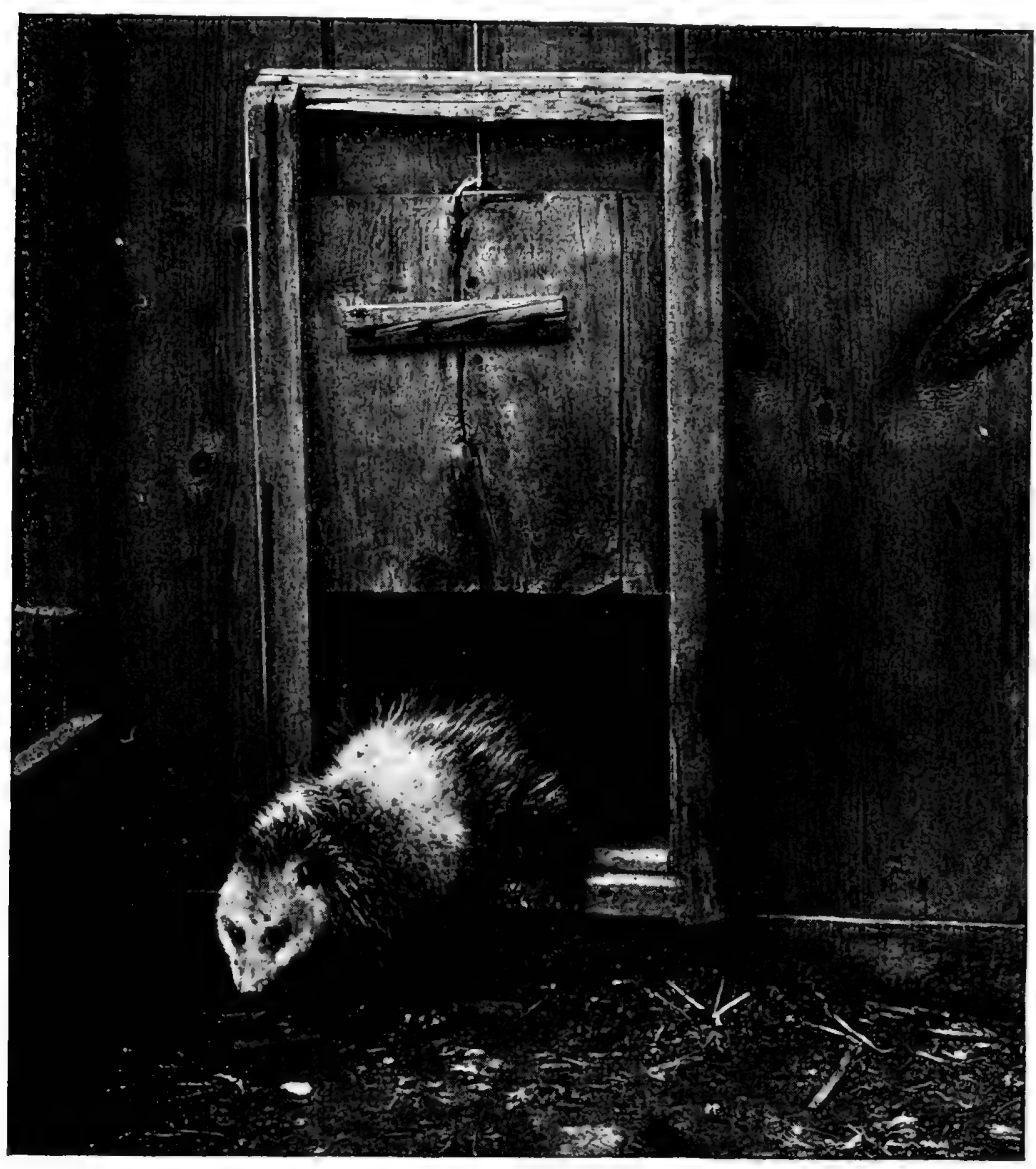

A Chicken-house Thief

the mother arches her tail over her back, very much after the fashion of a squirrel, and the little ones cling to it by their prehensile tails, heads down, and 
feet just touching her back, presenting a curious sight indeed. For a few weeks after they climb out of the pouch the young do not venture upon the ground, but return to the pouch for food and protection.

I have not been able to photograph any of these young opossums, but a farmer, knowing that I was interested in photographing animals, helped me to get some pictures of the old ones. He sent me word that there were a number of opossums about his place and that when he discovered anything of special interest he would let me know. One morning I received word that an opossum was in the chicken house. Camera in hand I soon reached the spot and found that the opossum had just completed a full breakfast upon fresh eggs. Leading from the chicken house into the yard was a small door; I focused upon this and then opened it. The opossum slowly came forth, and when he was in full view I pressed the bulb, and the old robber was taken.

The next week I was summoned again by the farmer and this time I photographed an opossum while he was feasting upon a nest of hen's eggs.

But it is in the South, on his native heath, that the opossum reaches perfection and his greatest size. For him the glowing October sun, and the silvery frosts of November, have developed the delicious 


\section{The Opossum}

flavor and fragrance of the persimmon. Through all the painted autumnal woods the opossum finds spread for him by the lavish hand of Nature this sumptuous

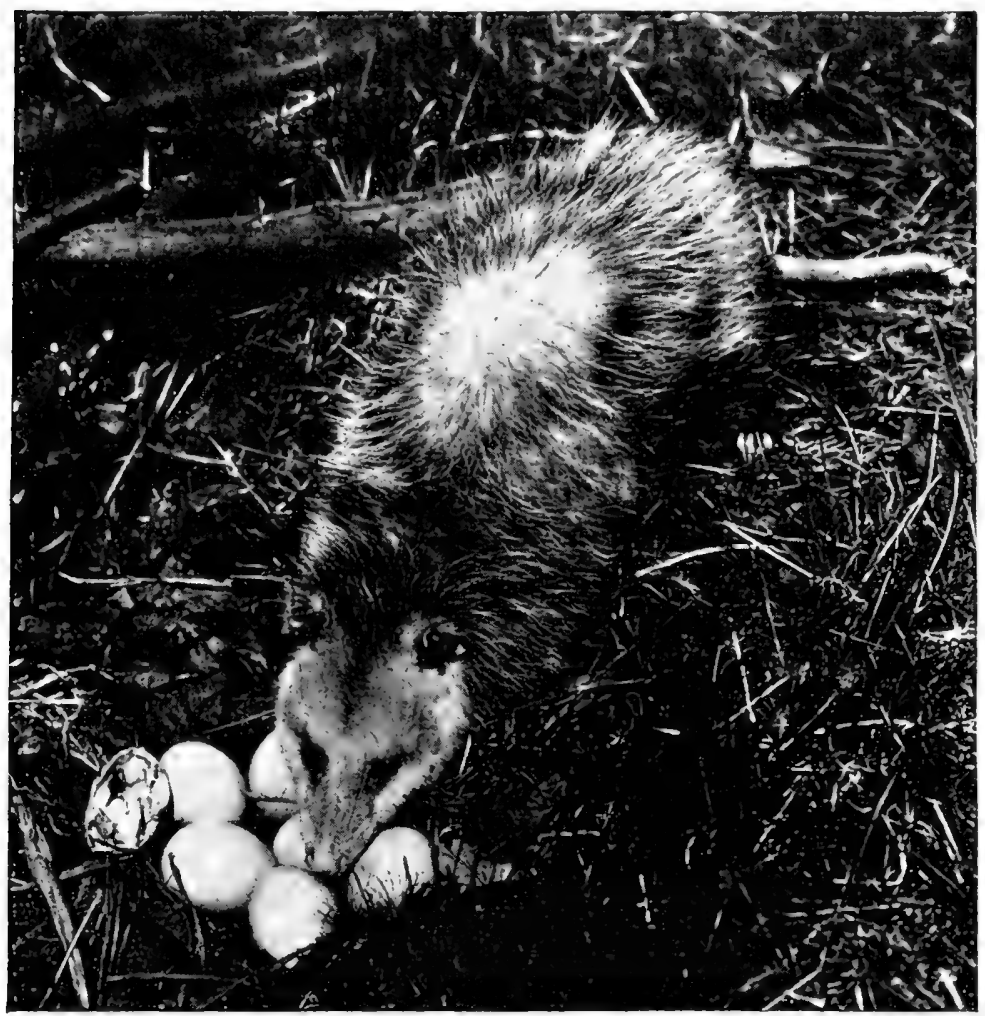

Feasting on EgGs

banquet of golden fruit. From twilight until the approach of day, the greedy little creature feeds upon the persimmons.

O, heedless opossum! Could you but see into the future you would not feed thus recklessly upon the 


\section{The Opossum}

the fruit, which in a few weeks must render you so temptingly fat! "Simmon" time brings in "possum" time, and from many a cabin the melodious negro voices, accompanied by banjo, accordion, or harmonicon, are heard singing:

"'Possum am a cunnin' thing,

He rambles in de dark,

Nothin' 'tall disturb his min'

But to hyah my bulldog bark."

The hunting of the opossum in the South is usually done at night, the one important feature of the hunt being a good opossum dog. The opossum will take to a tree at the approach of the dog, and the dog should remain barking until the arrival of the hunting party. If the tree is not difficult to climb the opossum is soon captured, otherwise the tree must be felled or the game shot. The colored people enter into the sport with the greatest zest, and these hunting parties have merry times.

The hunting of the opossum in the North is more frequently done in the daytime. The hunt is usually confined to the edge of a forest or large timber along streams and the more numerous the hollow trees the better. I remember a hunt of this kind: I had been tramping about with my camera, and as I was passing through some large timber near a clearing on the 


\section{The Opossum}

Orange Mountains, I came upon an old colored man and a boy, who were carefully examining the trunk of a tree. I asked them what they were hunting for. "Possum," was the short answer.

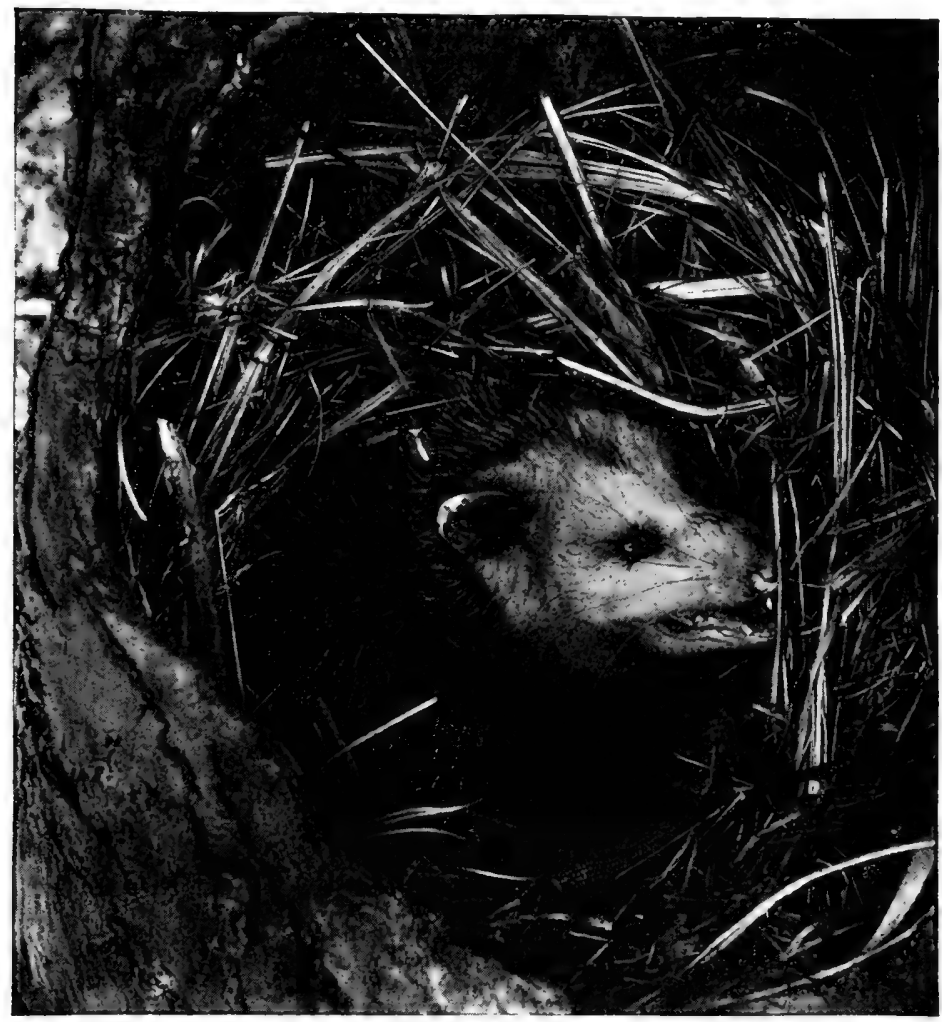

"O LoRd, Uncle Robert, a 'Possum!"

When the colored man, who, as I afterward learned, was familiarly known as "Uncle Robert," found that I was out after animal photographs, he granted me the privilege of joining the party. 
Uncle Robert's method of hunting the opossum was very simple; he knew of several hollow trees and from time to time visited them, occasionally

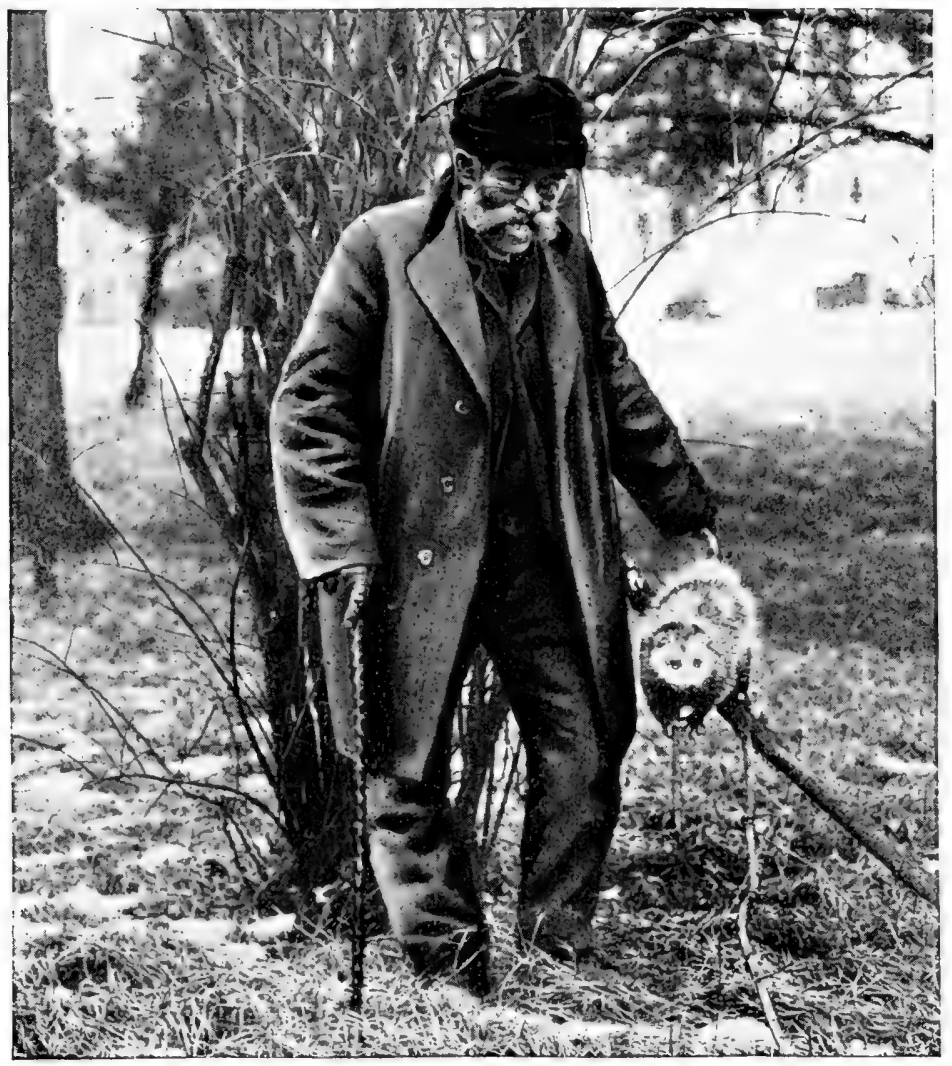

"De 'Possum and De Coon"

finding an opossum. He was not very talkative at first, but gradually warmed up to the subject of opossum hunting, and told me that when he was a boy and lived in "Old Virginny, we all used to hunt de 


\section{The Opossum}

'possum and de 'coon, for dey bofe is mighty good to eat."

While talking we were gradually making our way through the timber, and when we came to the edge of the clearing Uncle Robert called a halt. Immediately before us was an old hollow apple tree. The boy nimbly climbed to the hollow.

One glance was enough and he exclaimed, "O Lord, Uncle Robert, a 'possum!"

The cavity was a shallow one, and I succeeded in making a photograph before the opossum was removed from his snug nest. When removed he proved to be a large fat specimen, "'bout as good as downSouth 'possum," Uncle Robert declared.

The old man thought as long as I was taking photographs it would be proper for me to photograph "de 'possum and de coon togedder." A good idea! 


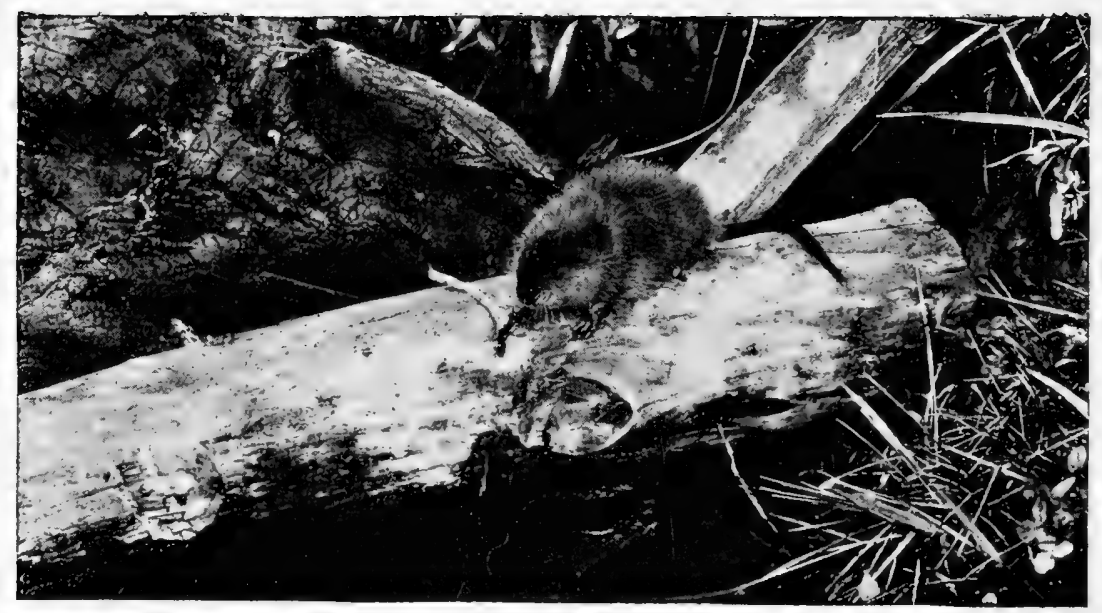

\section{THE MUSKRAT}

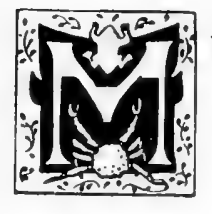

USQUASH is the Indian name for the muskrat, which being translated means 'the animal that sits on the ice in a round form.' We call it the muskrat, from the musky odor, due to the secretion of a large gland in the groin region, which is present in both sexes.

This little animal has a short neck and a round head and is about the size of a cat, the body, however, being more cylindrical. The forward legs are short and the feet are small, while the hind legs are much longer and the feet stouter. The toes of the hind feet are practically webbed, the general form reminding one of the foot of a duck. The graceful movements of the muskrat in swimming are due to the peculiar attachment of the hind feet to the legs and the sculling movement of the long, compressed tail. 
As with other aquatic mammals, the pelage of the muskrat consists of an under coat of soft, dense fur, while the outer is coarse and of longer hair. In many particulars the fur resembles that of the beaver, although it has not so much compactness and lustre. The prevailing color is a dark chestnut-brown on the back, changing to reddish on the sides, while the ventral parts, and particularly the chin and throat, are of a grayish hue. The fur was formerly a valuable article of commerce, and is still found in the market in small quantities.

The muskrat is found about ponds, lakes, and sluggish streams throughout the greater portion of North America. The character of the home, as I have observed it, depends very largely upon the nature of the country. Where there is an extensive swamp or shallow stretch of water along the main stream, the summer home is a burrow in the bank, while the winter home may be a hut or lodge in the swamp; if the stream be a narrow one, with little or no swamp, the burrow in the bank is the more usual abode. The entrance to the burrow or lodge is in water so deep that the passageway will not freeze in winter.

While stupid enough in most matters, the muskrat surprises us in manifesting a remarkable degree of intelligence in selecting certain marshes for its home. 
The favorite marsh is one supplied by springs. Here it is that we find the greatest number of winter lodges, the muskrat apparently reasoning that such places are not frozen over solidly. The date of building the lodges varies according to the weather conditions, most of them, however, being constructed in November. A lodge is the combined work of from three to six muskrats; it is built at night, and the materials used are coarse grass, sticks, leaves, twigs, and mud. While this lodge is in process of building it appears to be one solid mass, and from this I am led to believe that the nest is excavated after the lodge has reached its full proportions. When finished, the lodge extends two or three feet above the water and is about the size of an ordinary haycock. It is not symmetrical, one side being less precipitous, and it is most likely that up this incline the muskrats bring the material used in building. It is a snug little home, and probably very comfortable in ordinary winter weather. Here it is that the muskrats pass their time, except when in search of food. Their foraging excursions are usually made at night, and the journey may be some little distance from the lodge.

The food during the winter consists largely of aquatic plants. Somewhere on the feeding ground extending above the water and ice, one or more 


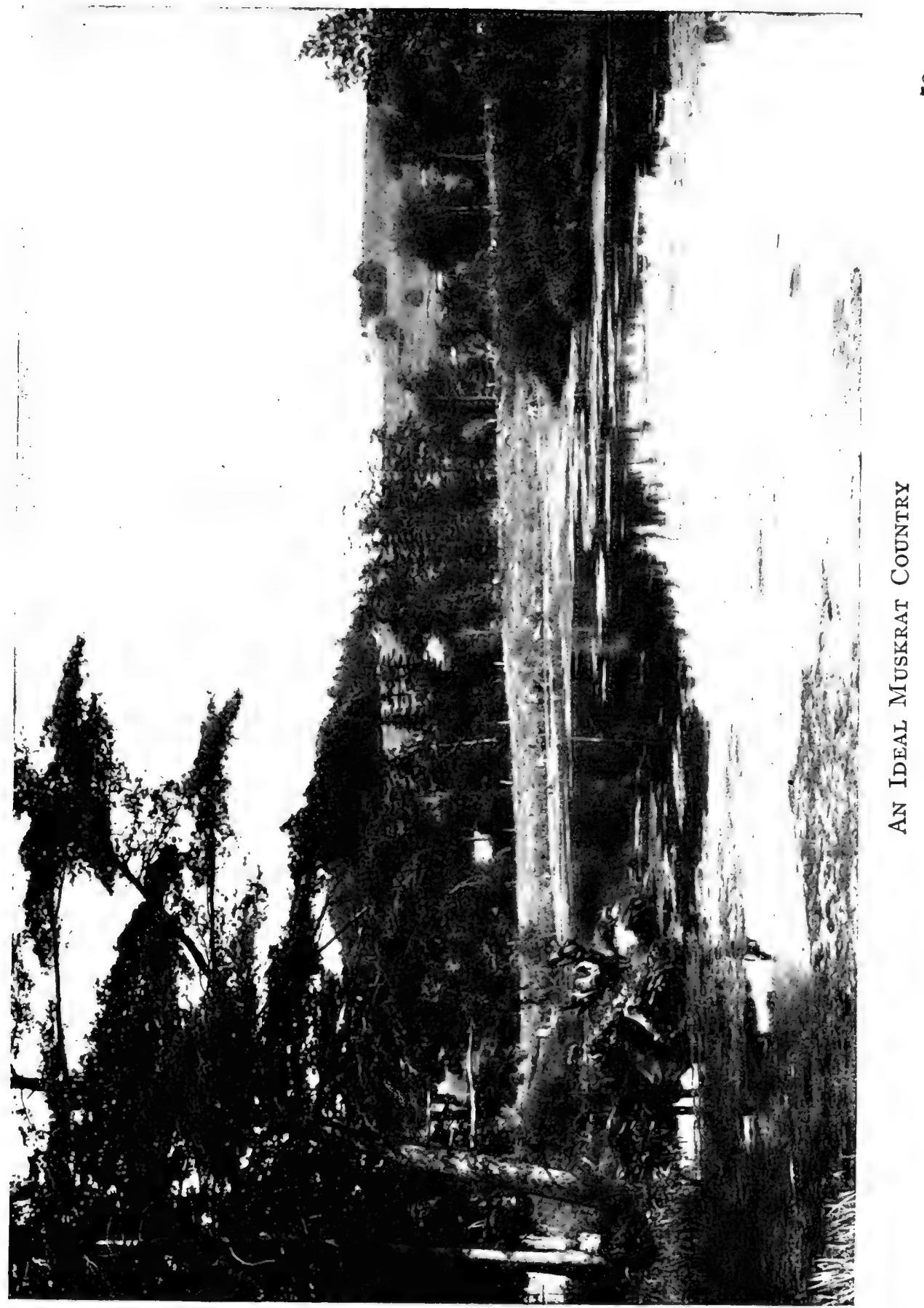




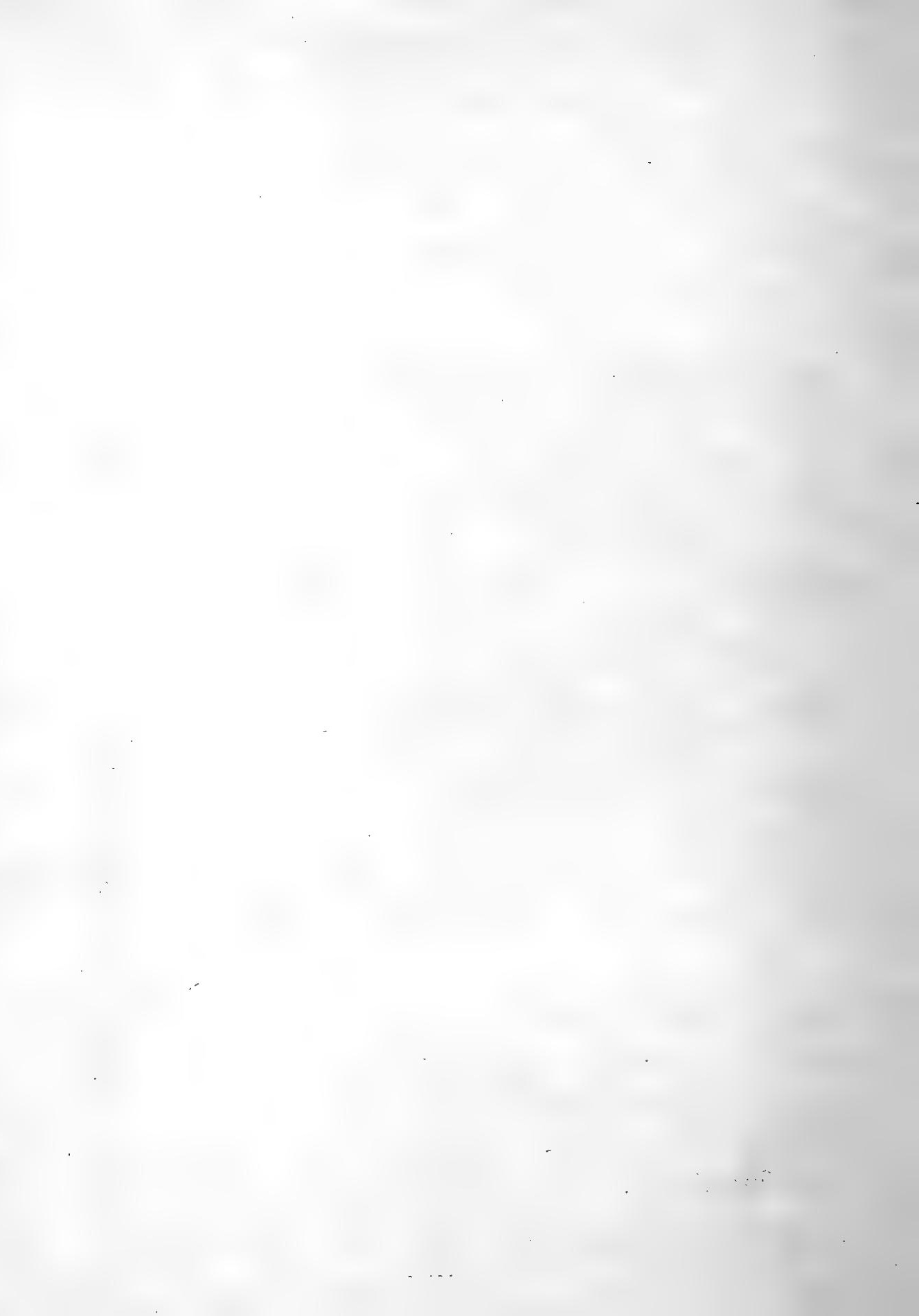


clusters of rushes are still standing. At such places there are usually air holes, the breathing places for the muskrat. He takes advantage of these holes and forces the refuse of his food through them, thus forming a little mound six to twelve inches in height. This

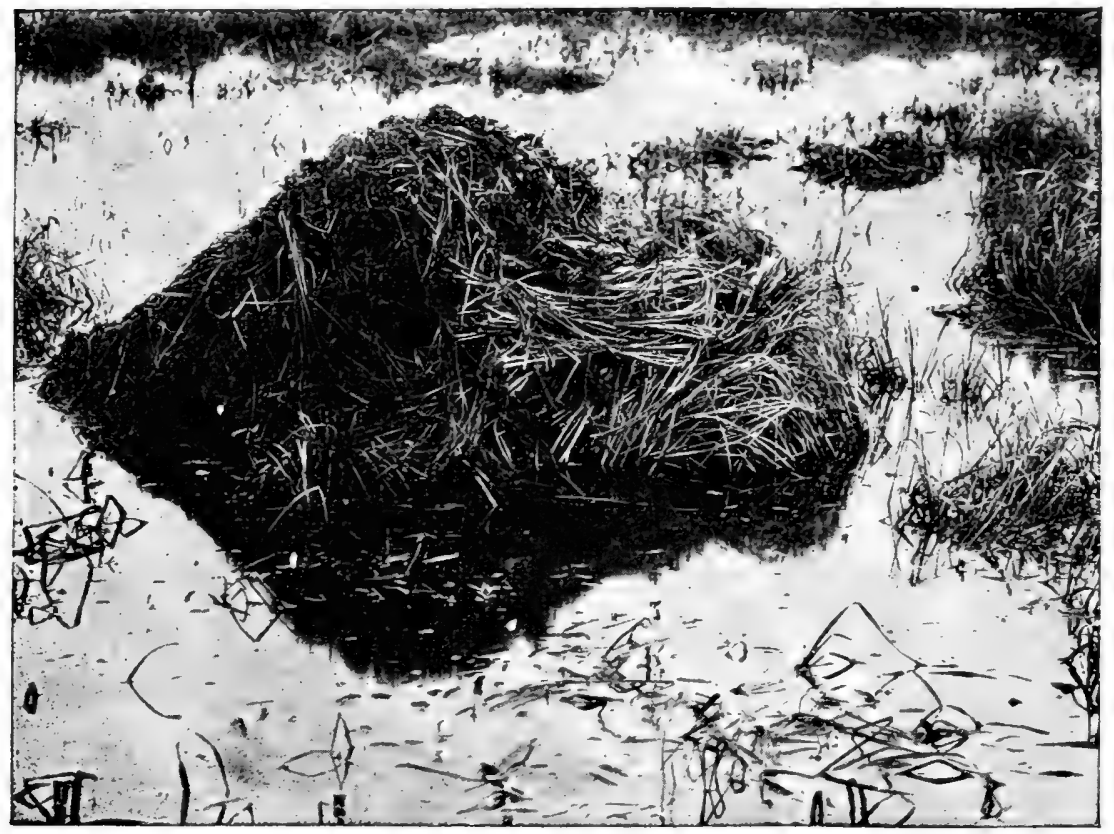

The IVInTer Lodge

wet material, along with a little mud, forms a compact mass, preventing the water from freezing below. Here the muskrat brings his food to eat, and here he obtains the necessary air, remaining the while in a sitting position, with his forward parts in the hut and his hind parts in the water. Sometimes if a lodge is 
disturbed the muskrats betake themselves to their individual huts until their fright is over.

At all seasons the food of the muskrat is in the main herbaceous, consisting chiefly of the roots of marsh grasses and aquatic plants. $\mathrm{He}$ is very fond of sweet apples and will venture quite a distance from home that he may enjoy this tidbit. Vegetable gardens situated along water courses are sometimes seriously damaged by a colony of muskrats. I remember very distinctly an experience which $I$ had in my younger days. Near the lower end of the garden, which was my care and pride, flowed a large creek along whose course were numerous sequestered pools and coves, set back well into the mainland and shaded by willows. The muskrat families that dwell about these ideal places were well supplied with the necessary vegetation, but this did not satisfy their appetites. In the latter part of August the vegetables in the garden began to disappear, and early in September the turnips, carrots, and parsnips were nearly destroyed. It did not dawn upon me that this was the work of muskrats until one evening a heavy shower left the soil of the garden very soft. In the morning the story of the marauders was plainly written on the telltale earth. The footprints were unmistakably those of the muskrat. Now knowing who 
the thieves were, it was easy enough to trace them by the fragments of the leaves strewn along the way from the garden to their burrows.

As I was curious to know what the muskrats had done with the vegetables, I opened a few of the burrows. Here I found the plunder snugly packed away, as though for winter use. The destruction of the garden was a neighborhood affair, for I traced the vegetables to burrows at least thirty rods away. It is worthy of note that, during the time the garden was being plundered by the muskrats, the greatest dcstruction occurred on cloudy nights, while on the morning following a clear night nothing would be missed.

I was unable to determine why the muskrats were so destructive this particular autumn, and it seemed strange that they had never troubled the garden before. The number of muskrats trapped during the fall did not show an increase over previous years.

The finding of the vegetables in the burrows naturally leads to the question, Do muskrats store food for winter use? I believe it is the exception when they do. I wish to relate an incident, although it is a seeming contradiction to the above statement. Not far from the garden and within two hundred feet of the creek stood a large apple tree. The apples 


\section{4

ripened about September first. Judging from the numerous and well defined paths leading to the old tree, the muskrats must have visited it almost nightly from the time of the earliest windfalls until the apples were

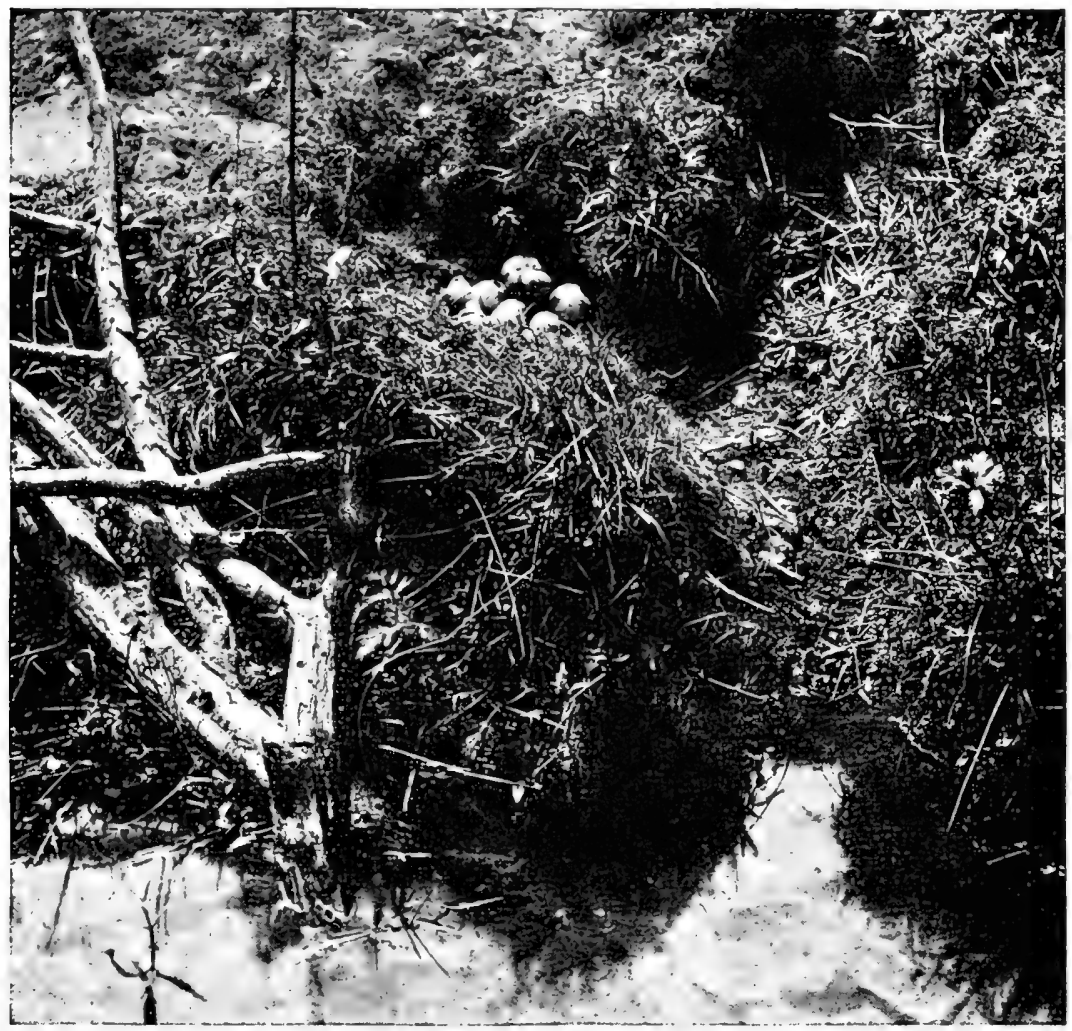

A Burkow Exposed Showing a Few Apples Stored for Winter

gathered. One of these paths was so well worn and there were so many remains of apples along its course that I decided to open the burrow from which it led. There was half a bushel of apples in that burrow! 


\section{The Muskrat}

Two years later another burrow in the same vicinity yielded a like amount.

When he can obtain it, the principal animal food of the muskrat is the fresh water mussel. I have found large heaps of these empty shells near the entrance of a muskrat home. The muskrat is also said to feed to some extent upon fish, especially upon those fish which half conceal themselves in the mud, as the carp, sucker, and catfish. It is also probable that during severe winters, when food is scarce, they devour one another. I am certain that if a muskrat is caught in a trap and remains there for some time, its companions will often turn upon it and devour it. This cannibalism is not peculiar to the muskrat family, for it exists among the wolves and other wild animals, and to some extent among the domesticated ones.

In certain parts of the country large numbers of muskrats are destroyed annually, not for their fur alone; but to prevent their becoming so numerous as to cause damage by making holes in the milldams, embankments, or ditches that happen to be inhabited by them.

The manner of hunting muskrats is about the same throughout their range. In the Northern States the trapping season begins about the middle of October, and the fur continues good until the following April. 
The prime fur, however, is obtained during the winter months. When I was a boy an old trapper told me that, like the oyster, the fur is good in any month of the year in which the letter $r$ is found. This old adage, like many others, is true within certain limits; even in the Northern States the fur in September and April is rather thin.

In snaring the muskrat, the trap is placed at the entrance of the burrow, or in a path leading from the water; but in either case the chain should be secured within its length of deep water. The muskrat's idea of freeing himself when caught in a trap seems to be to get into deep water. The exertion with the added weight of the trap will exhaust the strength of the muskrat and he will soon drown. Otherwise, if the trap is so fastened that he cannot get into deep water, after several hours he will usually free himself by gnawing off his leg.

Muskrats are very stupid about being trapped. If two or three traps are placed at short distances apart in a runway, the first muskrat passing will probably be caught, while a second and even a third may fall victims to the tempting bait, although usually the squealing of the two is sufficient to frighten away the third one for a time. Traps arranged in the order just described are visited between ten and 
eleven o'clock at night and again in the early morning. The muskrat is easily caught in a box trap, which should be lined with tin, to prevent his gnawing his way out.

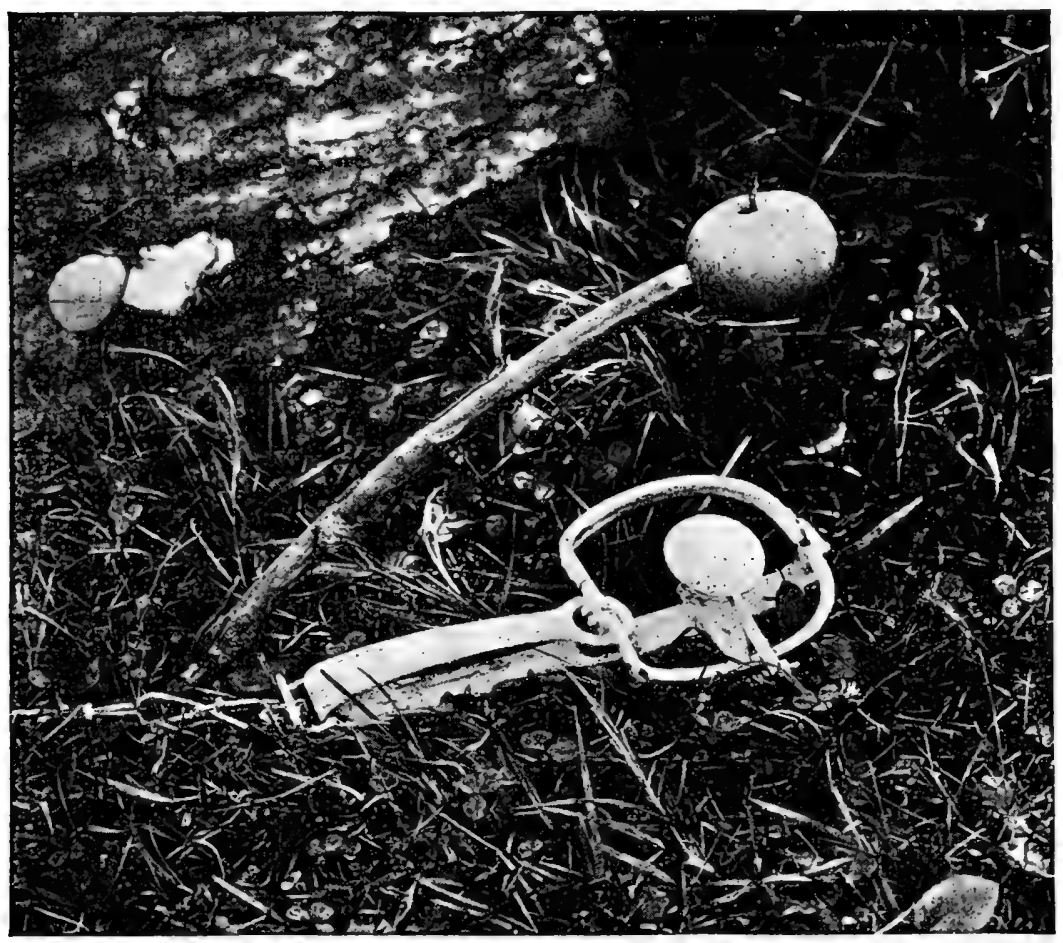

A Trap Baited for Muskrat

When the streams are frozen the trapping of the muskrat practically ceases and the. hunter will meet with better success if he visits the marshes, where the lodges are to be found. For this purpose the hunters go in parties of three or four. One member of the party carries a spear, which has, usually, four 


\section{The Muskrat}

prongs about eight inches long, while the others are each armed with an axe.

The party, thus properly equipped, arrives at the marsh and cautiously approaches a muskrat lodge on the southern exposure. This side being naturally the warmest, the muskrats are more apt to be found here, resting snugly in their warm beds. The experienced hunter can usually locate the exact spot above the muskrats by the delicate frostwork upon the outside of the lodge, produced by the warmth of their bodies. This spot having been located, the spearman drives the sharp prongs through five or six inches of the lodge wall, and usually pins one or more of the inmates; another hunter instantly breaks the lodge open with his axe, and assists in securing the muskrats already speared by his companion; while the other hunters watch for the escaping muskrats, as they plunge into the water at the first indication of outside disturbance. Usually the water is not very deep and the muskrats swim quite close to the ice. A sharp blow with the head of the axe upon the ice directly above the muskrat will ordinarily stun it so effectually that when a hole is cut in the ice, the game may be secured without difficulty. If the lodge is not badly demolished and the weather not too severe, the surviving muskrats will return the following night to repair their home. Thus 


\section{The Muskrat}

the hunters may secure muskrats from the same lodge at two or three different times during the winter.

The greatest destruction of muskrats occurs during the spring freshets. Especially is this true where the banks of the stream are low, for in high banks the animals can burrow upward and so keep beyond the reach of high water. During the times of flood many are drowned in the burrows, and those that escape are forced to swim from shore to shore, without shelter and without food. The hunters armed with guns then appear upon the scene in boats. If a luckless muskrat escapes one hunter by diving and swimming, his head scarcely shows above the water when he is shot at by another.

There is now no rest for the unhappy muskrats; every hand seems raised against them. Even the foxes and the minks and the great horned owls take advantage of their forlorn situation, and by the time the waters subside their number has become greatly reduced. I have known certain ponds, where many muskrat families had made their homes, to be nearly depopulated in one spring by reason of continued high water, accompanied with sleet and rain, and by the activity of two or three avaricious hunters.

I myself have hunted the muskrat, but it has been with a harmless weapon-the camera. It is some- 


\section{0

what difficult to get a snapshot at the muskrat, for it is largely a nocturnal animal. However, most of us can remember having seen them in the daytime.

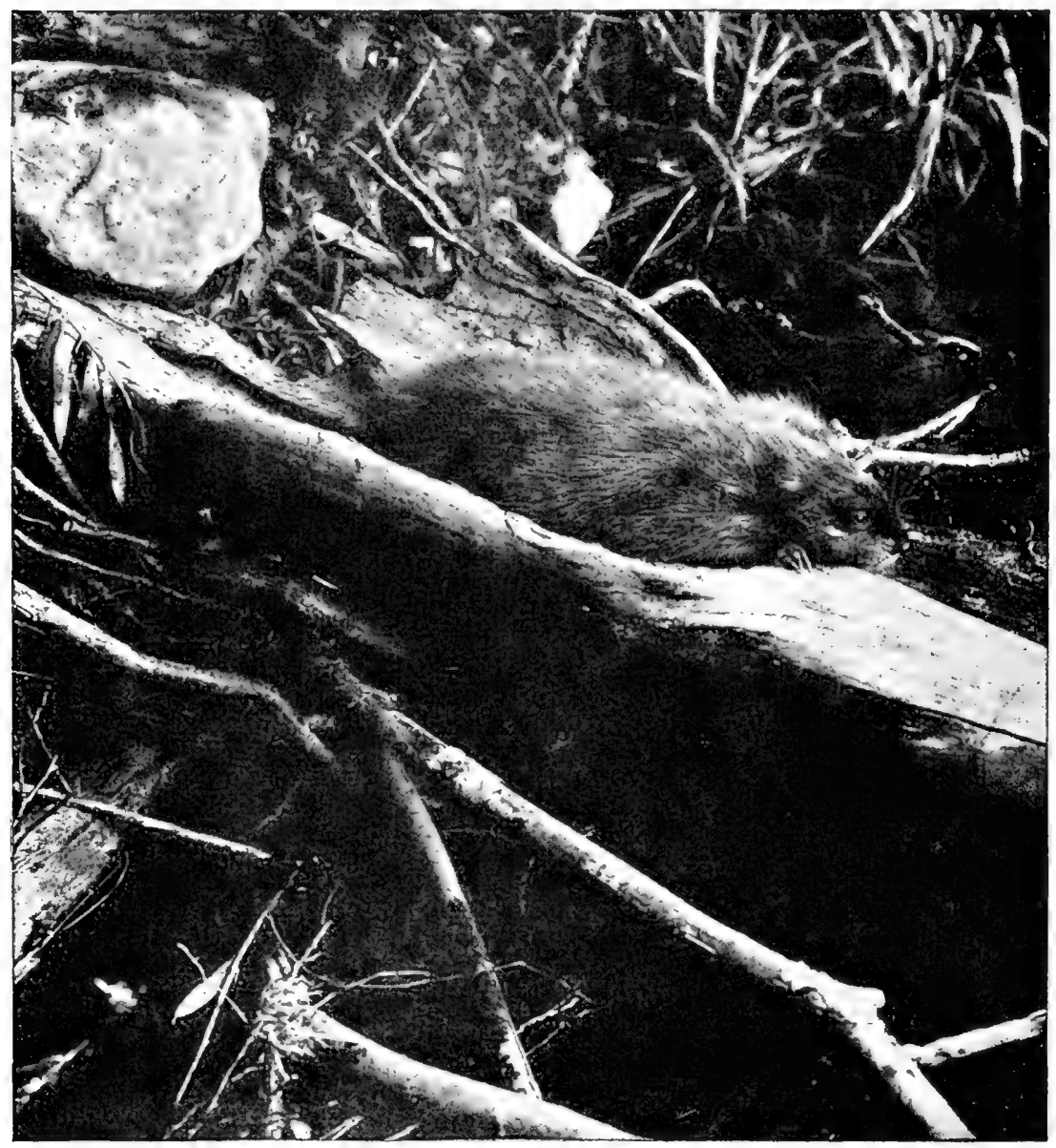

Muskrat Reclining on the Log

According to my observation, the latter part of August and the first of September is the best time of the 


\section{The Muskrat}

whole year to find muskrats abroad in daylight. With this fact in mind I set out to obtain some photographs.

My first step was to make a thorough search of the creeks and ponds for a thickly settled muskrat community. The place seeming to promise the best results was the upper portion of a mill race having on one side pasture land, while the other side was a steep bank under which were several burrows.

Near the water's edge, at about the same point on the pasture side, I had observed muskrats several times during the afternoon. I began by putting sweet apples in certain places, thus rewarding the muskrats which ventured abroad in daylight, but I took care to remove all remaining apples before sundown. I kept up this baiting process for about two weeks, and at the end of that time several of the muskrats made quite regular excursions for the apples late in the afternoon. From the pasture side of the mill race an old log extended from the bank over the water. I noticed a very large muskrat several times, after his frolic on shore, taking a reclining position on the $\log$ before he plunged into the water to swim to the opposite shore, where his burrow was located. After several attempts I succeeded in photographing the old fellow in this rather odd reclining position. 


\section{2 \\ The Muskrat}

The younger muskrats are not so shy as the older ones. The first photograph in this sketch shows one nibbling a plantain leaf.

These pictures were easily obtained in comparison with the one showing the muskrat swimming. This

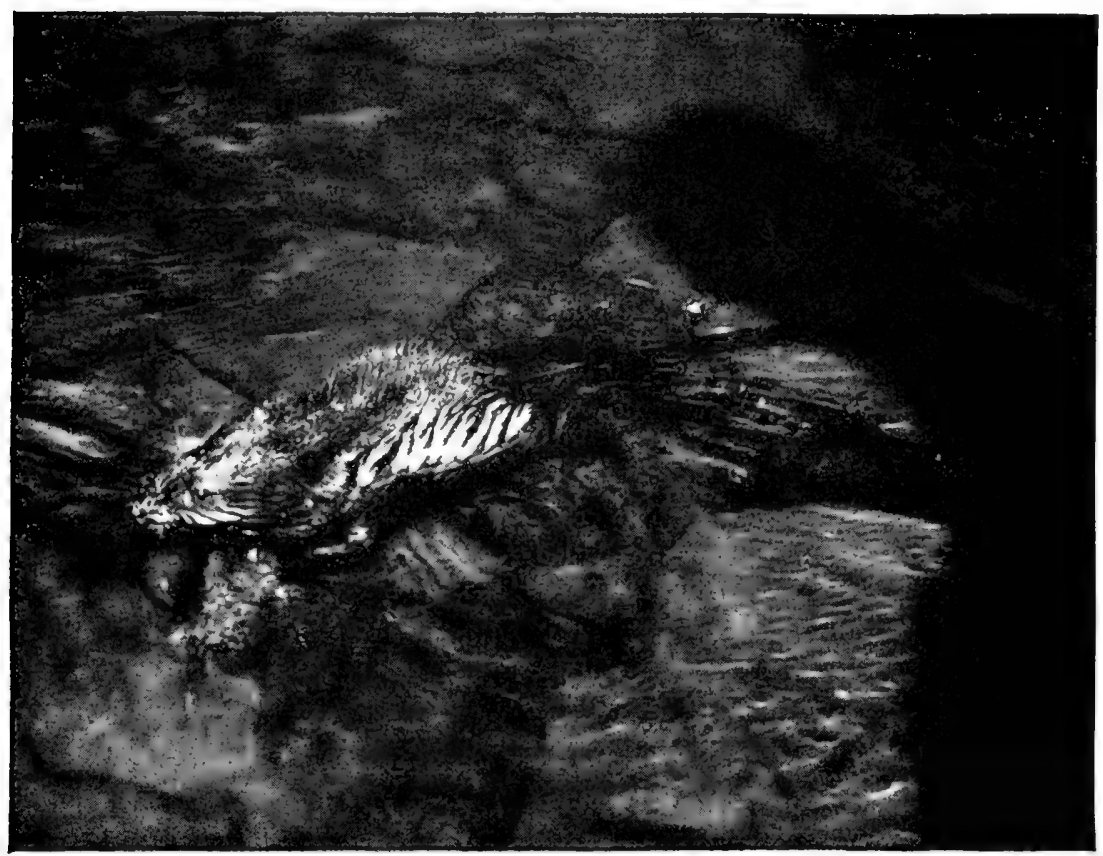

Muskrat Swimming

consumed all of my spare time, my plates, and my patience.

From these results it is readily seen that any one, with a real desire and a little inventive genius, can photograph muskrats; it becomes difficult only when 


\section{The Muskrat}

you so far forget yourself as to desire to get one in a certain position.

The ancient forest has been swept away and old water courses with their adjacent marshes have long since become dry. With these changes have vanished the beaver, the wolf, the moose, and the timid deer; the muskrat, however, has remained, wisely accommo-

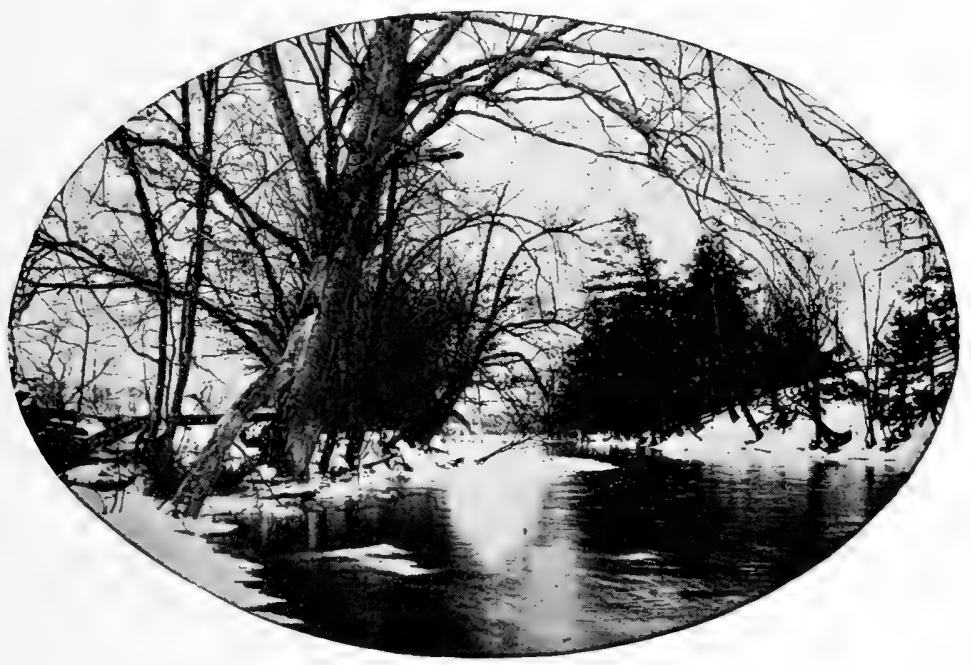

A Muskrat Stream in Winter

dating himself to the new surroundings until now his mode of life is almost as artificial as that which hems him in on all sides. We love to think of him in the open marsh, where the "boom" of the bittern mingles with the deep bass of the frogs. It is here in early summer, at the close of day, that we may find 
94 The Muskrat

the young muskrats sporting among the lily-pads, where the mother duck is softly calling to her little ones, as she retreats among the tall weeds. May the days of the muskrat continue for untold generations, that mankind may never forget the world's past wildness! 


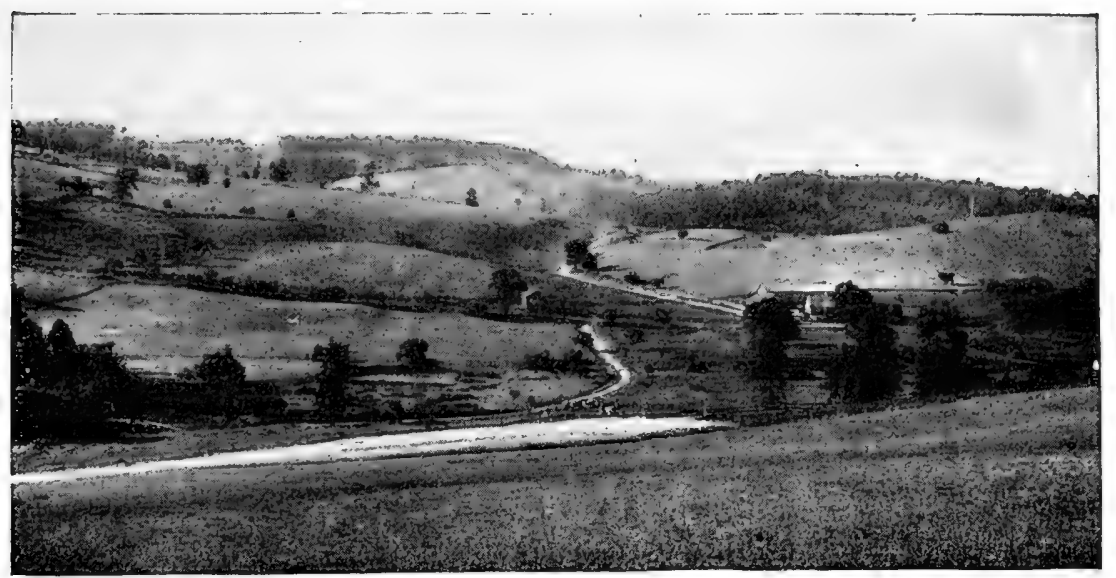

A Typical Fox Country

\section{THE FOX}

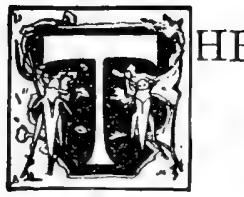

fox is called the slyest and most cunning of our common wild animals. From the time of earliest animal lore, to "old Reynard," have been ascribed attributes which would lead us to believe him to be endowed with something that many are unwilling to concede to the lower animals,-something that seems more than mere instinct, a something akin to reason.

The fox is wily and cunning and sagacious, to such a degree that he taxes to the utmost the ability of our best huntsmen. Even with the aid of trained hounds and with a knowledge of the runway of the fox, the sportsmen are often eluded and outwitted by the artful Reynard. Traps, deadfalls, and all sorts of devices are used for his capture, and his ability to 
escape them can but command a certain respect from his human pursuers, a respect which cannot be felt for an animal like the opossum.

In the shadowy depths of his mother's burrow, the baby fox first opens his eyes upon a world in which his part is to be a continual struggle; struggle not only for daily sustenance, but a struggle to escape the snares and pitfalls laid for him by his arch enemyman. Among the fox kindred it is a survival of the fittest, combined with a wonderful development of hereditary habit, which has fostered, and in some cases multiplied, their race.

When pursued by a hound, the fox may deceive it in several ways, such as doubling on his trail, walking on fences, or wading in shallow water. The last ruse is by far the most effective. Nevertheless the hunting of the fox is most successfully accomplished by means of the hound. In the Northern States the hunting scason begins in November; but the real sport comes a little later, when the ground is covered with a light snow, for then the hound can follow the trail more easily. A trail must be fresh if a dog is to follow it over the frozen ground with any degree of speed, and on a ploughed field it is almost hopeless.

Perhaps a few reminiscences of fox hunting will serve, better than anything else, to give those unac- 


\section{The Fox}

quainted with this clever animal clearer notions as to the scope of fox sagacity:-To begin with, it should be borne in mind that foxes, unless old and experienced in guile, will not, when hounded, run far away on a straight course, but will circle near the home where

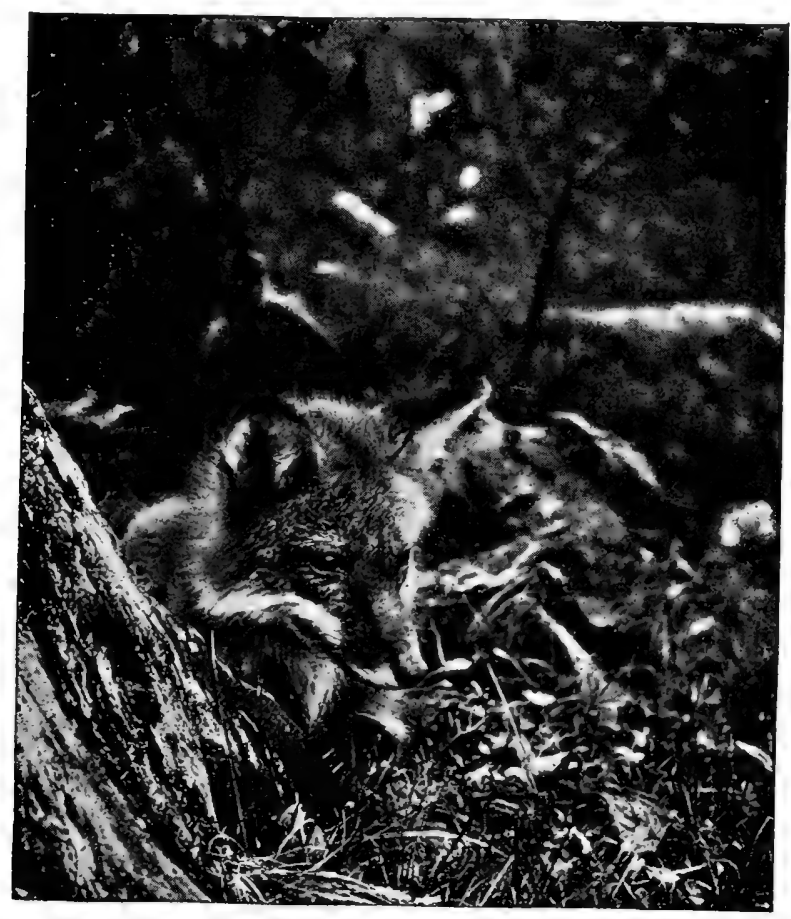

An Interested Fox

they were reared. It is also well to know that foxes have certain runways through valleys and across hills, through swamps and along water courses, and that these are followed more or less regularly by the fox, either when pursued or when quietly moving 
98

\section{The Fox}

from place to place in search of food. This fact is taken advantage of by hunters, and the runways must be located before success in the hunt can be expected.

In the fall of I880 foxes were very plentiful in the State of New York on the hills between the Unadilla and Chenango rivers. There was scarcely any snow until late in November, and when it did come it was very dry, the wind blowing it from the fields and hill tops, and drifting it along the fences. Notwithstanding the bareness of the fields, thoughts of the old time sport tempted the more adventurous hunters. Two of these enthusiastic Nimrods set forth with a well trained hound before the snow had stopped sifting about even in the less exposed places. The hound soon struck a trail, and as the track was fresh he seemed to fly over the snow. The deep toned baying sent the blood tingling through the veins of both pursuer and pursued. The first hunt of the season was really on! The men took positions of vantage on the supposed runway, watching and listening carefully for the expected game. Meanwhile the hound had gone quite out of hearing to the north. An hour passed and no fox appeared. Nothing was heard save the baying of the hound far away to the east. In half an hour the fox appeared in a valley, over which the hunters commanded a distinct view. 


\section{The Fox}

As the fox could not take to the water in the frozen streams, he tried another trick which worked admirably. It was this: Within the valley and in sight of the hunters were two ploughed fields, each containing a marked elevation. The wind had swept these higher areas completely bare of snow and loosened bits of earth had rolled away, until the surfaces were quite smooth. The runway of the fox may have been across these wind-swept places. Be that as it may, the fox crossed each in turn. When the hound came upon the first place he lost the trail for a time, but finding it, proceeded to the second. The fox, instead of continuing his course as would naturally be expected, returned to the first by a circuitous route and then again to the second. He repeated this manœuvre three times, taking the same course each time, finally quitting the game by turning sharply to the left, and making off to the south, leaving behind him a most weary and perplexed dog.

At another time a fox was seen to follow a rail fence for about forty rods, nearly in the opposite direction from that in which he had been traveling; he then jumped from the fence upon the ice of a small creek. By this ruse he succeeded in completely eluding the hounds.

If the fox is an old one and has often been before the 
hounds, he tries in succession several blocks to the trail, thus gaining time and tiring the dogs. I once knew a fox to throw the hound from the trail by taking to the highway for a distance, passing among a large number of cows feeding about a stack, and finally walking a fence; all this within half a mile. Why did the fox go among the cows? Did he reason that his passage would scarcely be noticed, whereas the hound would create quite a disturbance among the cattle,-enough disturbance to confuse him and perhaps cause him to lose the trail? Since the fox was far in advance of the hound and there was no immediate need for such an unusual act, and knowing as I do the cunning of Reynard, I am led to believe that this move was not entirely accidental.

I knew one fox to enter a village while being pursued; another ran into a large barn by one door and out through another on the opposite side; and still a third crossed the dooryard of a farmhouse and went upon the porch where a man was standing, actually crouching nearly exhausted at his feet as though begging protection from the relentless hound.

When the snow is soft and deep the dog with his longer legs has the advantage, and sometimes the fox is overtaken and killed. At such times, I ob- 


\section{The Fox}

served, the majority of foxes seemed to realize their great disadvantage, usually keeping so near to their burrows that, when hard pressed by the hounds, they could "hole up" as a last resort.

Let us look at some of the common methods employed by hunters in securing foxes that "hole up." The fox may be "dug out." This is serious business for a hunter when the ground is frozen to the depth of two feet or more, but if he decides that this is the thing to be done, he borrows a pick and shovel from some near by farmhouse. If the "boys" are at home, the wise old hunter incidentally mentions that he has "holed" a fox, and at once he has assistants at his command. Before the digging begins a slender green stick is cut, with which the direction of the burrow is determined, and a pit is sunk some four or five feet from the entrance. Then another bearing is taken and a second pit is sunk, and by this means much labor is saved. Sometimes a divide in the burrow is discovered, but the dog usually determines in which one the fox is hiding; at other times the fox may be heard digging, and his whereabouts is thus disclosed. The scene now becomes one of great excitement for the boys and dogs, each getting in the way of the other, and delaying the capture. If no large stone or root interferes, the fox is soon ex- 
posed, and is usually seized and despatched by one of the dogs.

Another method of ferreting the fox, when rocks and stones make digging impossible, is that of "smoking him out." Dry punk is set on fire and, when burning well, is forced some three or four feet into the entrance of the burrow. Through the lack of sufficient air, quite a quantity of smoke and gases is formed, which after a time becomes diffused through the remotest parts of the burrow. This is a new enemy to the bewildered fox, and one on which his usual cunning has little effect. In his last desperate effort to escape, he tries to gain the entrance of his burrow, but falls exhausted near the smouldering heap that not only blocks his way, but is pouring forth its deadly fumes. After about two hours the remaining mass is raked out and a slender, slightly forked stick inserted and twisted about. In so doing the end usually becomes entangled in the fur of the fox and he is then easily drawn to the entrance of the burrow.

Still another method of capture is sometimes attempted, that of "drowning out the fox," but this is seldom successful. It requires a large quantity of water, and often the soil is so porous that before the second supply can be added the first has been absorbed.

But we must not forget that these "holes" are 
interesting from another point of view, besides that of the hunter-they are the homes of the foxes. Here, during the springtime, on a soft bed of grass and leaves the fox babies are born. They are lively little fellows, varying in number from three to seven. So rapidly do they grow that the amount of labor expended in procuring food for them is great. The parent foxes must hunt day and night. At such times the female becomes daring, and has even been known to invade farmyards and capture poultry in the daytime.

I have become acquainted with several fox families, and very much have I enjoyed their friendship. All but one of these families were allowed to rear their young; the exception being in the case of a pair so destructive that they were dug out, and the young kept as pets. I wish to speak in particular of this family, not that they differed so much from others, but because I knew them better.

It was in an open pasture, during the first week in May, that I discovered their den. During the spring four or five hens had mysteriously disappeared, and one day I saw a fox not far from the barn. There was nothing remarkable in this except that the fox was the darkest in color I had ever seen, outside the black species. The disappearance of the hens was 


\section{The Fox}

now no mystery, a den of foxes being less than a quarter of a mile away. Such being the case, I began at once to cultivate the acquaintance of the family. In the parents I expected to find the ordinary red-fox variety, so common about the region; but one of them was extremely dark in color.

The entrance to the den looked like a very large woodchuck's burrow, save that it bore evidence of more constant use, and that scattered about were bits of fur and feathers of various kinds.

The first time I visited the burrow I did not see any foxes. After this, whenever I was near the burrow the darker colored of the old foxes was usually to be seen on a knoll not far away, sitting dog-fashion and occasionally uttering a sharp bark. I seldom saw the red fox, which I supposed to be the male, unless a dog accompanied me. In that case the darker fox would retire and the red one would come closer, apparently inviting the dog to a chase. However, since the dog was not a fox hound, he would soon return, only to be provoked again by the near approach of the fox. I watched this most interesting strategy several times, but not being entirely satisfied, I chose a hound instead of a shepherd dog and, keeping firm hold upon the chain, I approached the den, resolved to study the situation, until I could ascer- 


\section{The Fox}

tain the meaning of the peculiar behavior of the foxes.

The red fox behaved exactly as before-approaching in plain sight and, when the dog was loosed, leading him on a "straightaway." In a short time the distant baying of the hound could no longer be heard. Not until the next morning did he return. For my own satisfaction and for that of those who are interested in fox lore, I repeated the experiment three times within ten days, with the same results.

On one occasion I took the hound to the knoll which was so often frequented by the female fox. Away he went on a fresh trail to the south. At intervals I could catch his baying, as he emerged into a clearing or passed over an eminence. After twenty minutes these sounds failed to reach my ear. During this time I had remained seated on the knoll from which the hound started. Imagine my surprise when, on hearing a fox bark, I turned and saw the dark colored fox standing not more than twenty rods from me! What did this mean? I was now at very nearly the spot from, which the fox had started less than half an hour before. The hound had taken the trail at this point, and had gone to the south-and here the fox was back again!

For two hours I rcmained near the den, but nothing 


\section{66 The Fox}

was to be seen of the dog. Toward evening he returned home. Knowing the cunning of foxes, and believing that they can reason in a general way, I was curious to learn more about them. Accordingly on the third day succeeding the incident of the sagacious female fox, I led the hound near the den and put him upon her trail. As far as I could judge, they passed over the same course as before; the fox appearing after about the same lapse of time, taking up her station near the den, where she remained for a short time and then disappeared. I went home in about an hour, and the hound was not heard again that day; but in the morning he was resting on the doormat, apparently as happy as though an old fox had not fooled him.

This, with other data, furnished me material for serious thought in regard to this foxy family. Having satisfied myself sufficiently, as I believed, to warrant conclusions, I once more repeated the experiment with the hound and the female fox, with practically identical results.

From these experiments it seems reasonable to believe that, while the young are in the burrow and unable to care for themselves, it is the business of the male fox to keep dogs away from the den by leading them on "straightaways." I am led firmly 


\section{The Fox}

to believe, also, that if the dog strikes the trail of the female fox, the male in some way crosses off the female, taking upon himself the burden of the chase. Certainly the cases I have cited point to this conclusion.

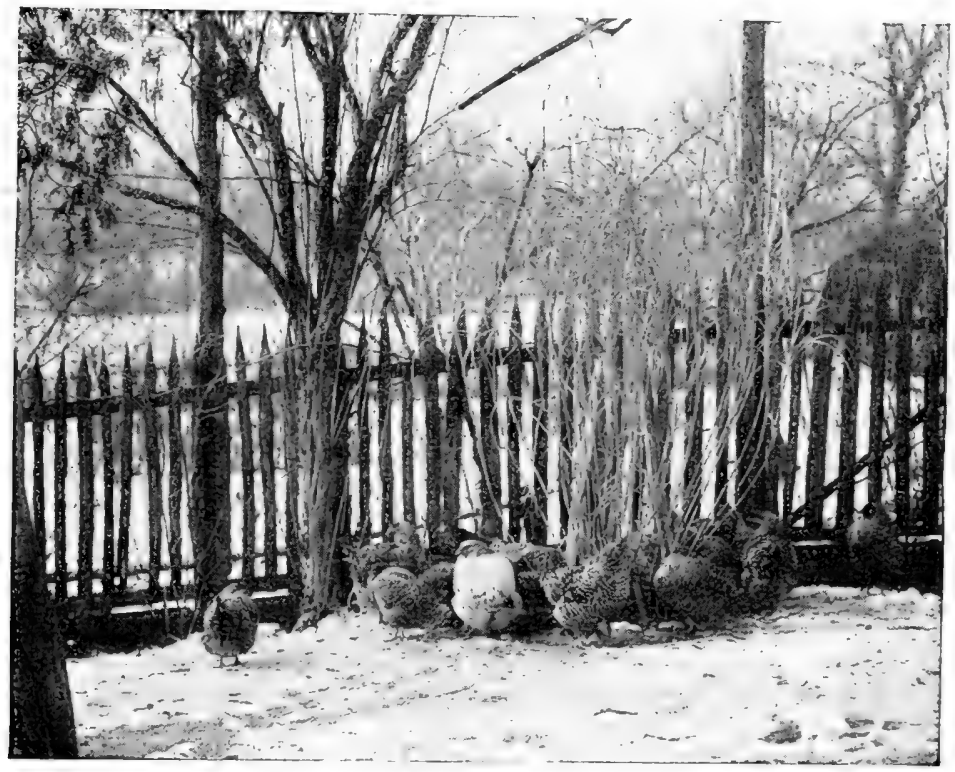

The Dreali of the Wind Fox

The duty of providing food for the young foxes does not rest entirely with the female, although the real responsibility seems to be hers. At all events, when food becomes scarce, it is the mother fox that, even in the light of day, and almost in the presence of man and dog, will venture near enough to the barns to catch a fowl for her starving little ones.

This condition of home affairs is true not only of 


\section{8 \\ The Fox}

this fox family, but of all others which I have observed, and I have reason to believe that it is usual among foxes. In other animal families similar results have been observed. As has been stated, foxes raised in a certain locality usually remain near home, probably bringing up their own young within a few miles of the parent den. So, too, with pumas. A single family lives within a given territory and the male and female, as a rule, hunt separately, as do the parent foxes. The female puma is a far better hunter than the male, and when hard pressed for food for her young she becomes very bold and daring. Yet in proportion to her size and strength she does not surpass the mother fox.

A division of labor between parents is not a fact among the mammals solely; it is common among birds-among some the division being quite equal, while with others it is very unequal.

This division of care for the little ones of a family must be excellent domestic economy. Certainly my little fox friends were the fattest and glossiest little fellows imaginable. There were six of them, four red and two darker colored ones. It was most interesting to watch these little fellows at play; they would chase each other about, rolling and tumbling, tugging over bits of sticks, or sometimes over their 


\section{The Fox}

food, and jumping about their mother, especially when she was lying upon the grass. Sometimes the mother fox would play with them much after the fashion of a dog. Twice I saw the male fox at the den.

We are told that sometimes live mice and occasionally other animals are brought to the den for the little foxes to play with and iater to feast upon. Only once did I see anything of this kind, the victim in this instance being a young woodchuck. It was evident from the woodchuck's movements that the mother fox had not injured the prey. It was amusing to sce the antics of the young foxes. They were very cautious at first in their approach. Sometimes in their haste to retreat they fell over each other as the woodchuck made a dash for them. The old fox had to recapture the woodchuck several times and on the last occasion killed it, whereupon the little ones enjoyed a good feast.

I have yet to know a den of foxes that so regularly and systematically drew for its supply of food upon one poultry yard as did this one. The fowls being allowed to run at large, the ducks and hens and particularly the turkeys often strayed some little distance away. A greater part of the missing fowls were taken during the day, for at night they were shut in the poultry house, or, as in the case of the turkeys, 
were out of harm's way, high in the trees near the garden. Matters went from bad to worse. And when my favorite Dorking cock was served to the young foxes, it was too much! Straightway the foxes were dug out and the young were given away as pets. The old foxes were not killed, but after the day the young were taken I do not know that I saw the parents again. At dusk that evening I saw a shadowy form near the little house which had been prepared for one of the young foxes. For several nights the barking of foxes was heard not far away, and sometimes the little captive made bold to answer. Through worry and confinement, and perhaps improper food, the little fox quickly lost his plumpness and the glossiness of fur. One morning a dead partridge was found beside his prison door, probably killed and brought there by the mother fox. Purposely, on the following evening the collar of the imprisoned fox was gently loosened, and the door of his house left ajar. In the morning the collar lay beside the door, and I imagined that the little fellow was safe with his mother among the hills.

I learned in the following autumn that two more of the young foxes escaped. I hoped that they would journey back to the valley in which they were born, never again to be trammelled by collar and chain. 


\section{PHOTOGRAPHING A WILD FOX}
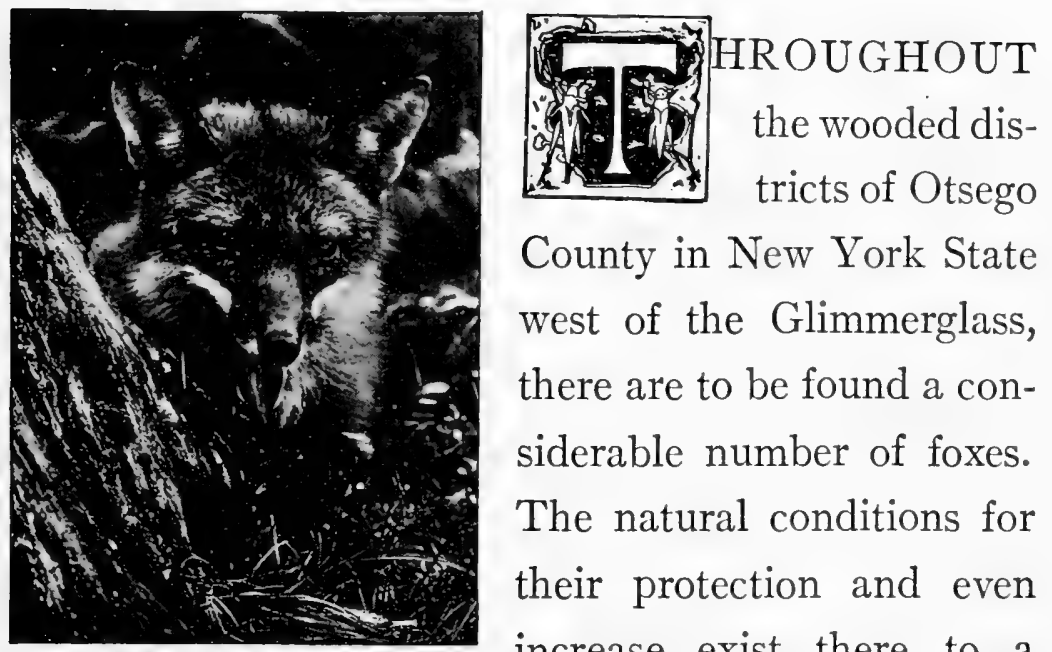

County in New York State west of the Glimmerglass, there are to be found a considerable number of foxes. The natural conditions for their protection and even increase exist there to a marked degree. Although the woodsman has worked great havoc among the pines, hemlocks, and chestnuts that once covered the high hills of the district, here and there even now may be found a comparatively large forest. The ground, not being found suitable for agricultural purposes when cleared, has been allowed to run wild, and a luxuriant growth of scrub oak and pine, cherry, a few evergreens, and a tangle of brier have taken the place of the larger timber. 


\section{I 2 Photographing a Wild Fox}

The whole section, therefore, offers ideal homes for the foxes.

The same conditions, too, which have naturally protected the foxes have had a like influence on the ruffed grouse and other small game which largely furnish the food supply of Reynard; but they, like himself, have learned cunning from long experience, and he often finds the domestic fowl which has ventured too far from the protection of the farm-boy and his $\operatorname{dog}$ a more easy victim. This fact makes the fox especially obnoxious to the farmer in the thinly populated districts of this region. During the hunting season many are shot, but their numbers are nevertheless gradually increasing.

It was during the tapping of the sugar bush that some boys noticed numerous fox tracks in the snow. They also caught an occasional glimpse of a long, slim body gliding as silently as a shadow into the dwarf hemlocks by the swamp, and the watchers of the sugar camp at night were often startled by shrill barking just outside of the circle of light. This reminded the boys of the gradual disappearance of their father's fowls, and the oft repeated threats against Reynard; and they determined, when the hurry of sugar making was over, to turn their attention to the destruction of their troublesome neighbors. 


\section{Photographing a Wild Fox}

Meantime the sun had slowly climbed higher and higher in the heavens until the days were spring-like indeed. This sort of weather aroused the wild nature of the domestic turkeys and they longed for the open fields and woods. With many misgivings the farmer at last opened their prison door one morning and set them free. All day long they roamed the meadows, and at night returned safely to roost in their old places in the apple trees near the house, but later in the evening there was evidence of some disturbance among them. Old Sport, the hunting dog, joined in with his deep toned voice, the vigorous tugging at his chain telling of his eagerness to be free. So great was the disturbance, that the farmer thought it best to liberate the dog. Away he sped through the garden, past the apple trees where the turkeys were roosting, and on toward the swamp. The frequent bayings of the hound indicated close proximity to game, but after half an hour he could no longer be heard. It was evident that he was on the trail of a fox and that the fox had led him on a "straightaway" far to the south.

The next morning Old Sport returned, very weary from his long chase, but wagging his tail in silent welcome to the little family which had just arrived to spend the spring and summer at the old farm. 


\section{4 Photographing a Wild Fox}

The subject of the foxes and their depredations soon became an all-absorbing topic, and the spirit of the discussion was thoroughly entered into by those of us who were called visitors. We had longed for the wholesome country life and sports, and the foxes promised to furnish just the right tonic for tired heads and overworked nerves.

The second night after our arrival the foxes again came close to the house, barking and causing signs of alarm among the turkeys. The next morning was clear and bright, the balmy air gave a sense of new life, and the fields and woods, tinged with that delicate green so characteristic of the latter part of May, invited us thither. As soon as the dew was off the grass we took Old Sport and started for the maple grove. We had not gone far before the dog was off on a fresh scent, which led him along a range of hills on the west side of a valley, extending to the south for about two and a half miles. It was not until the middle of the afternoon that he returned.

The disappearance of the fowls and the frequent hunts of Old Sport continued for about a week, but during this time we had seen a fox only twice. However, we were satisfied with only a small beginning. As our study continued, longer tramps were necessary, with cold lunches or with none at all, and I soon 


\section{Photographing a Wild Fox}

found that the others preferred different amusements of a less fatiguing character. The motive of my interest in the foxes being very different from that of the farmer and his family, my enthusiasm was less easily dispelled. I was bent, not on their destruction, but on learning more of their habits and real lifehow they cared for their young, and how they protected themselves from the many dangers that beset them, and upon obtaining, if possible, some photographs of wild foxes.

One day while in an old stump lot which sloped south, I caught a glimpse of a large fox, as he disappeared behind a knoll and then reappeared a little farther on. He trotted leisurely across the open pasture, never once turning his head or in any manner indicating that he had seen me. He was not fifteen rods away and would have been an easy shot, but I would not have killed him for all the poultry in the farmyard.

I immediately seated myself by an old stump and focused my field glass upon the beautiful animal. This was no sooner done than the fox, which probably had been watching me all the time, sat down, dog-fashion, and turned his gaze full upon me. For ten minutes there seemed to be an equal fascination between man and fox, and then a sudden change 


\section{6 Photographing a Wild Fox}

came over the fox. My perfect quietness seemed to disturb him. His frequent change of position, the occasional opening of his mouth, and other quick nervous movements told very plainly of the strain he was undergoing.

During this time I had lowered the glass and was gazing intently at him, and never for an instant did he take his eyes from me. I was at a loss to know how to proceed, for I very much desired a closer acquaintance with this wonderful old $f_{0 x}$, who had matched his wit against that of man and of the trained hound. He evidently had a similar inclination, for he slowly raised himself, stood at full height for a moment and then advanced probably fifty feet. Here he stopped an instant as if to reassure himself that he had made no mistake, and then trotted toward me, a little to one side of a direct line, and came to rest on a knoll above me about six rods away.

Up to this time I had paid but little attention to his specific characteristics, but now his position, as he stood silhouetted against the sky, gave me an opportunity to study him in detail. There were the long shapely legs, the bushy tail, the well-rounded body, the delicately poised head and pointed nose, and above the beautiful eyes were the ears inclined forward as if to catch my very thoughts. Thus he stood for 


\section{Photographing a Wild Fox}

fully a minute, keeping his eyes fixed on mine, and then turning suddenly he disappeared among the brakes.

Before this I had known the fox only as a shy and cunning animal, but this one had shown another side. My attitude of friendliness towards him seemed to be reciprocated, and I believe that with me he had lost some of the fear that was so evident in his relation to other men.

I was now certain that his den and family could not be far away; so the next morning I led the dog to the place where I had met the fox on the day previous. Almost before I had time to remove the dog's collar the fox appeared, not a hundred feet away. In a moment the dog had sighted him, and away they went to the south over the old course.

I now devoted my time to a search for the den, and within twenty minutes I stumbled upon it. It was strange that I had not found it before, as I had been within a few feet of it several times. The surroundings were picturesque about the home of the foxes. On the same level, the den could not be seen unless you were very near, but if you knew where to look for it, it could be seen from an elevation about fifty rods away across a little ravine.

I found exactly what I had expected to find, and 


\section{8 Photographing a Wild Fox}

having found it, I was more worried than the foxes, for I feared some one else might discover it too. If so, the young would be dug out, the home destroyed, and my fox-study ended.

It was nearly noon when I completed the study of the den and its surroundings. To the south I could hear the hound, but after waiting some time for him to come back I returned to the house without him, and he arrived about two hours later.

During the afternoon I laid plans for the further study of the old fox. The following morning I led the dog to the former place of starting. The fox immcdiately appeared just as he had done the previous day, and away they ran over the course of the morning beforc. With field glass in hand I followed until I reached a point on the side of the ravine opposite the den from which I commanded a full view of the valley below, as well as of the den. Here I concealed myself and awaited further developments.

The sound of the hound's baying died away in the distance, and for an hour the stillness was broken only by the occasional song of the birds and the chirp of insects. Then again I heard the hound, and in a little while he appeared in sight in the valley below. He had apparently lost the trail, and so it proved; for in another half-hour he passed my place 
of concealment on the way to the house. I watched until the middle of the afternoon and saw nothing more of the old fox.

The next day I repeated the experiment, and watched particularly for the appearance of the dog in the valley. I found that he lost the trail in about the same place near the creek. Some time before this I saw the fox coming up the creek near the den, which he passed, never so much as turning his head, and I soon lost sight of him among the ferns and low bushes. The dog worked the trail for some time longer, and finally gave it up and went to the house.

By this time I thoroughly understood the action of the dog. Now I must watch for the fox. On the third day, as the fox and the dog started as before, I watched carefully the place where the dog had lost the trail. Two hours later I saw the fox, on his return trip, on the top of a stone wall at the place where the hound lost the trail each time. The wall at this point was so near the creck that the fox could jump from the wall to the bed of the stream. The banks were low for some distance, and I could see him in the shallow water making his way towards the den. As the banks became higher he was lost to view, and I turned the glass upon the creek, which was fully exposed near the den. In a little while he passed this 


\section{20 Photographing a Wild Fox}

point, and farther up the creek came out upon the high ground and, seating himself near a stump, carefully surveyed the valley below.

At first he seemed very calm, but became more restless as the hound appeared in the valley. By the

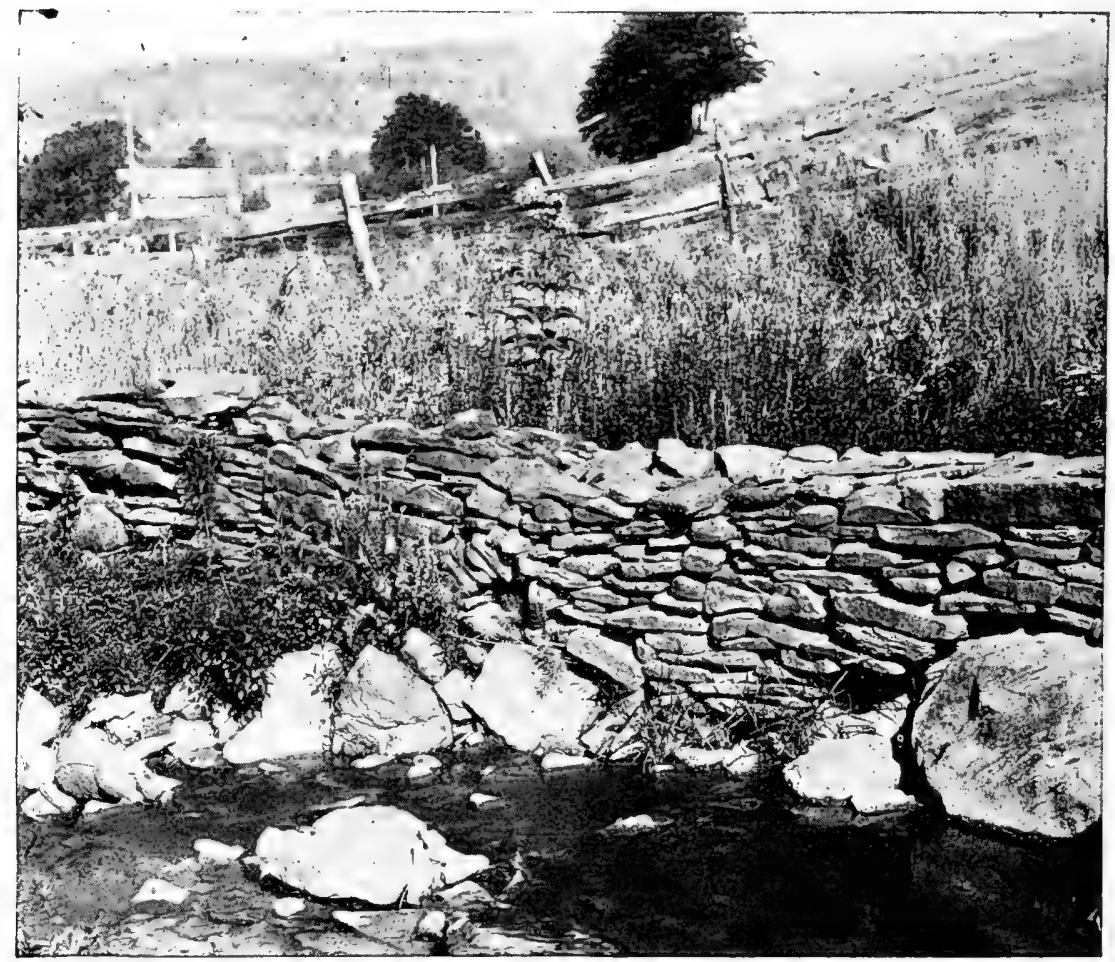

The Stone Wall Where the Dog Lost the Trail

time the dog had reached the place where the fox had taken to the wall, the fox in his apparent delight lost all control of himself. He jumped and frisked about and seemed to enjoy the perplexities of the 


\section{Photographing a Wild Fox 12 I}

dog with almost human intelligence. As the dog became more and more bewildered, he gave vent to his disappointment at intervals in long-drawn howls, until, uttering one prolonged howl, he gave up the struggle, returning to the house by the way of the west side of the valley, passing near my place of concealment.

Thereupon the fox became quiet, resting in a position half concealed by a stump, where he could watch every movement of the dog. After the dog had passed, the fox sat up on his haunches and watched him until he was out of sight, when almost instantly the fox turned and disappeared among the low bushes which skirted the maple grove.

The performance was repeated almost to the letter on the following day. The situation was now perfectly clear to me. The fox was on guard at the head of the valley, ready to lead the dog away, and after completely fooling him, returned by way of the creek to his vantage-point at the upper end of the valley in the stump lot.

It was now time to attempt to photograph the fox; his acquaintance had been carefully cultivated, his method of deceiving the old hound studied, and his appetite satisfied with many a fat chicken. Knowing something of his resting places at the head of the ravine, where he watched the hound in the valley 


\section{I22 Photographing a Wild Fox}

below, and being supplied with a long focus lens and a release to the shutter, that could be operated from two to three hundred feet distant, I felt reasonably sure of success. The camera was properly con-

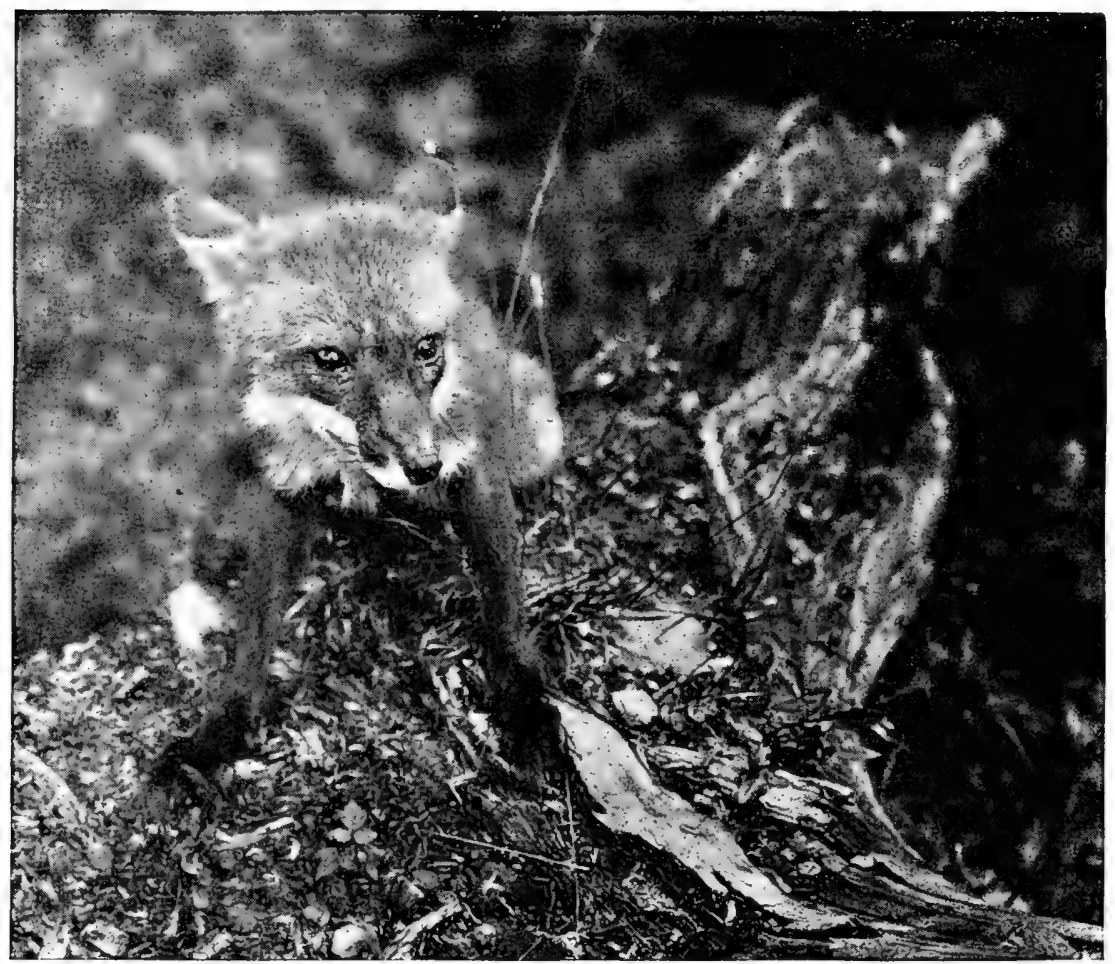

The Fox Watching the Hound

cealed, and after about two weeks of constant work there were found, among the numerous failures, four fairly good negatives.

Just after photographing the fox I was compelled to be absent from the farm for a few days. Upon 


\section{Photographing a Wild Fox}

my return I visited the haunts of the foxes, and a sad spectacle awaited me; the pick and shovel, worked by willing hands, had turned the den into heaps and trenches of reddish colored soil. I afterwards learned that a boy had discovered the den, and at once the foxes were dug out, and the mother and four little ones killed.

I saw nothing of the fox during the following week which terminated my stay at the farm. At night I sadly missed the barking that used to sound from the grove or meadow, and sometimes even closer to my window; but still more did I miss the graceful form that I had so often seen in the stump lot at the head of the valley. I left with the secret hope that the tamest of wild foxes was still alive and might long outwit those who sought his life. 


\section{THE WHITE-FOOTED MOUSE}

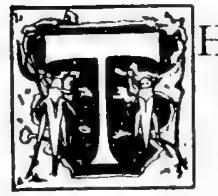

HE white-footed mouse is by far the most beautiful species of the genus to which it belongs. Indeed it is almost a shame to call this handsome creature a mouse at all! $\mathrm{He}$ is almost a dandy in dress and neatness, and his spotless robe of grayish fawn above is sharply contrasted with the pure white beneath. This, coupled with the natural grace and agility of its movements, distinguishes the white-footed mouse as one of our most attractive little mammals.

Combined with this grace and beauty there is a gentleness of disposition reminding one of the flying squirrel-indeed it is said that these two little wooddwellers are sometimes found living in the same cavity. An adult white-footed mouse when captured wild will seldom bite if taken in the hand, and after two or three days of confinement it is as gentle and confiding as though it had been born in captivity.

The home of the white-footed mouse is occasionally found in deep forests of evergreens or deciduous 


\section{The White-Footed Mouse}

trees; but its usual abode is along hedgerows, in the fields, or even in dwellings about well wooded sections of the country. The hunter's camp is very sure to be visited by them, and sometimes their friendliness becomes a burden. While their usual food is nuts and seeds of various kinds, they soon learn to eat almost anything about the camp. These little fellows show a most surprising capacity for food, and when once a hungry hord of them takes possession of the camp, well may the hunters and trappers look carefully after their stock of provisions; for when the snow lies deep through the forest and the nearest store is forty miles away, then is every ounce of flour and meal precious.

This little rodent has sharp teeth which sometimes he uses in a careless and inconsiderate manner; cord, fish line, hunting tackle of various kinds, and even snares set for other animals are cut to pieces. The trap is often sprung and the bait which might have caught a mink or marten has been devoured by this small midnight marauder.

Under favorable circumstances the white-footed mouse stores up considerable quantities of beechnuts for winter use. These seem to be his favorite nuts. Occasionally, when nuts are not attainable, seeds and grains of various kinds are stored. The nuts are usually shucked when gathered, at least this has been 


\section{26 The White-Footed Mouse}

my observation, and placed in a hollow of a tree or log. Woodsmen often find these stores of nuts. Several years ago I found a storehouse of some whitefooted mice in a cavity of a maple tree. There were nearly three and a half quarts of as beautifully shucked beechnuts as one would wish to see. Only last year I found in a stump another storehouse, containing a quart of beechnuts and an equal amount of buckwheat.

The white-footed mouse, like some of the squirrels, constructs an outside nest, in thick tangles of bushes, from four to ten feet above the ground. The favorite location seems to be about some gently inclined vine, such as the wild grape, which affords a natural and easy highway from the ground to the home of the wee architect. The nests are slightly globular in shape, and composed of dried leaves, grasses, moss, and fibrous barks of various kinds, the material being closely compacted and the general appearance very pleasing. The entrance is usually on the lower side. Sometimes the foundation is an old bird's nest, very often that of the catbird. I once found a nest that was fifteen inches in length and about eight inches in diameter, this being the most irregular in shape as well as the largest one that I ever saw.

Occasionally several mice will occupy the same nest, 


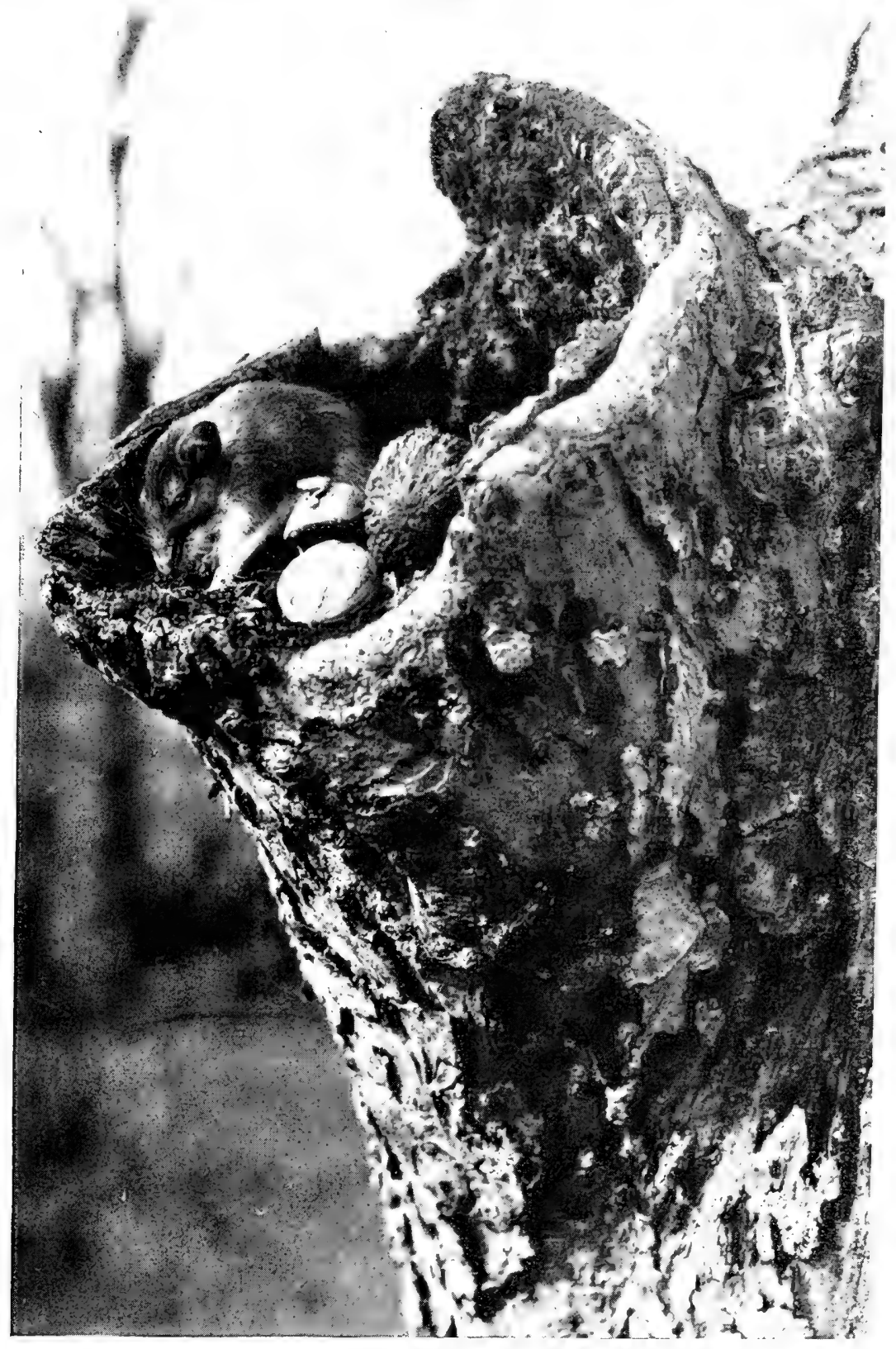

White-footeid Mouse 



\section{The White-Footed Mouse}

and if disturbed they hasten out, making their way along the branches to the ground. If the disturbance is slight, they come out upon the branches, gaze about on all sides and gently sniff the air, not returning until they are satisfied that all danger has passed.

Among the various species of mice there has been found from time to time the "singing mouse," and even among the white-footed variety it is no exception, according to a note that appeared in the American Naturalist several years ago by Mr. Hiskey, who wrote as follows:

"I was sitting a few evenings since, not far from a half-open closet door, when I was startled by a sound issuing from the closet, of such marvelous beauty that I at once asked my wife how Bobbie Burns (our canary) had found his way into the closet, and what could start him to singing such a queer and sweet song in the dark. I procured a light, and found it to be a mouse! He had filled an overshoe from a basket of popcorn which had been popped and placed in the closet in the morning. Whether this rare collection of food inspired him with song I know not, but I had not the heart to disturb his corn, hoping to hear from him again. Last night his song was renewed. I approached with a subdued light and with great caution, and had the pleasure of seeing him sitting among his 


\section{30 The White-Footed Mouse}

corn and singing his beautiful solo. I observed him without interruption for ten minutes, not over four feet from him. His song was not a chirp, but a continuous song of musical tone, a kind of to-wit-to-weewoo-woo-wee-woo, quite varied in pitch."

This does not mean necessarily that the whitefooted mice as a species are musical or that they have any considerable vocal power. I believe, on the contrary, that they are nearer mutes-attracting attention by drumming with their toes, a habit similar to the "thumping" of rabbits.

In spite of midnight revels and feasts upon beechnuts and grain, the existence of the white-footed mouse is one of eternal and anxious vigilance; its bright eyes must be ever on the watch for the shadow of hawk and owl, whose descent means swift and silent death; its sharp ears must be ever listening for the slightest stirring among the leaves, which may herald the coming of its dread enemy-the weasel.

I was once passing through a thicket, when an unfamiliar sound caused me to stop to listen. Peering through the brush I discovered a screech owl standing on the side of an old bird's nest, only a short distance ahead of me. It was after sundown, but the light was sufficient to enable me to see objects quite distinctly some distance away. The little owl 


\section{The White-Footed Mouse}

was absorbed in tearing apart what at first sight I supposed to be the bird's nest. So intently was he engaged in this task that I approached unobserved, and when within thirty feet of the bird I discovered that a white-footed mouse had placed his home on

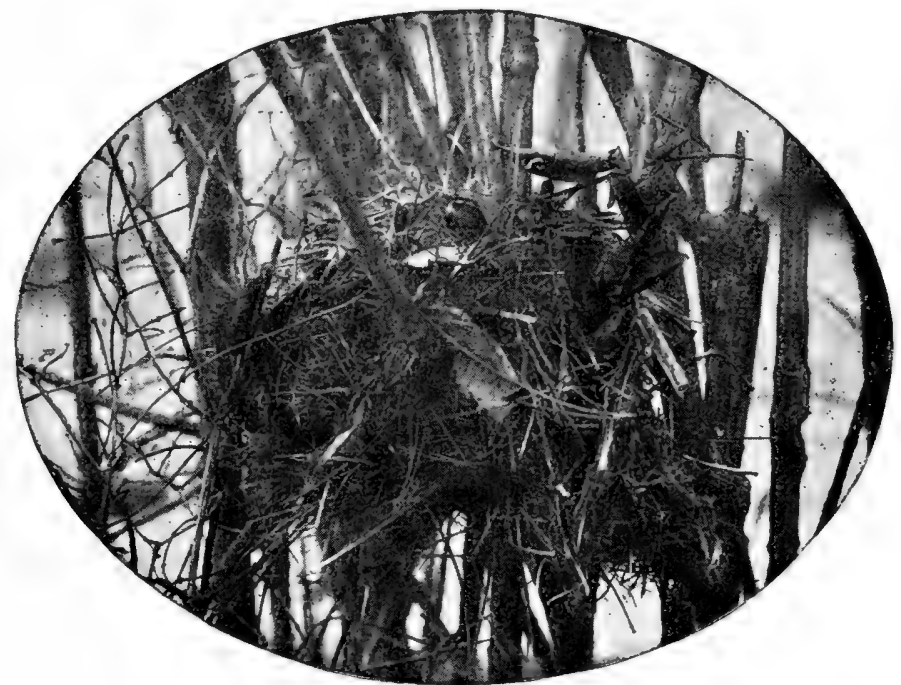

The Nest of the White-footed Mouse

the top of the bird's nest. The owl evidently knew that it was the abode of a mouse, for he was opening the nest by using both his beak and claws. Suddenly a white-footed mouse sprang clear of the nest, which was not more than four and a half feet above the ground, and struck upon the dried leaves below. Instantly the screech owl dropped upon him and bore him away in his talons to some evergreens near by. 


\section{32 The White-Footed Mouse}

This was the only time that I ever caught the screech owl in the act of hunting the white-footed mouse.

As a pet the white-footed mouse is very interesting. In captivity it resembles in many ways the flying squirrel, especially in its fondness for climbing about your person and hiding in your pockets. 


\section{THE GRAY SQUIRREL}

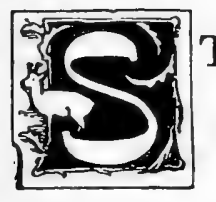

TEADILY the forests have been felled, and with them the gray squirrels have gradually disappeared, until their numbers have so decreased that for a hundred and fifty years there has not occurred one of those great squirrel migrations so common in the United States during the time of the early settlers. Guided by an impulse still unfathomed by naturalists, the squirrels congregated in vast armies and marched across the country. The distance over which they moved was largely governed by the obstacles which they encountered-rivers, lakes, and mountains. The climatic conditions and the food supply by the way, according as they were favorable or unfavorable, lengthened or shortened these migrations. As the squirrels pushed blindly forward, thousands upon thousands perished by the way, and the survivors gradually spread over a great territory, until lost in the vast wilderness.

Years might elapse before another great migration 
would occur over the same route, but parts might be crossed by other migrations starting from different points. Then there were the lesser migrations, with fewer numbers-caused by a failure of nuts in certain sections-that extended over distances from sixty to two hundred miles. Everywhere the squirrels left desolation behind them in the path of these migrations, the nut, fruit, and grain crops being sometimes ruined. So destructive were they that we find on the statute books in many States rewards offered for each gray squirrel killed.

Every man's hand was against them, and throughout the whole year they were shot and trapped whenever possible. In addition to this, regular hunts were organized, in which the whole male population took part, hundreds of squirrels being killed in a single day.

On a small scale these squirrel hunts were quite common in Central New York as recently as I840, and even to this day they occur in parts of the country. My great-uncle, Wesley $\mathrm{H}$. Lottridge, described to me one of these hunts, in which he participated.

The hunt took place in the town of Columbus, New York, in the month of October, I850. My uncle was appointed captain on one side, and "Uncle" John Richer, captain of the other. According to 


\section{The Gray Squirrel}

the rules, by a certain date each captain posted in the village inn a list of his men, consisting of nine besides himself. On the day of the hunt the participants started as early in the morning as they pleased, but ceased shooting at the disappearance of the last rays of the sun. The hunters then collected at the inn, where the squirrels were counted by judges, and the men sat down to a banquet in the preparation of which quantity was even more to be considered than quality; for the men were literally as hungry as hunters, having worked hard with only a cold lunch since breakfast. The party having the smaller count paid the bill of all.

These hunts were similar to the wild pigeon hunts of sixty years ago, and to the jack rabbit hunts of the West.

The presence or absence of the gray squirrels, or black, which is a color variation of the same species, depends upon the nut crop. They are the most abundant, strange to say, when the nut crop is a failure, which happens about every other year. This is accounted for by the fact that contiguous districts the fall before were without nuts, and so the squirrels went into the adjoining region where the nuts were plentiful. Here there would be enough for all until the addition of the young in the spring, which would increase the number of squirrels above the normal. 
Toward autumn, the nut crop being a failure in this district, the squirrels migrated into regions round about where food might be found.

The home of the gray squirrel is usually to be found in a hollow in a maple, birch, or beech, with the entrance among the branches forty to sixty feet from the ground. This is the real home, although often in the spring a summer house is constructed. This is generally located in the same tree with the other home, so that if the squirrels become frightened, they may run for shelter to the more secure dwelling in the hole of the tree. This second home may be for convenience during the time that the young are being reared; perhaps it is built for sanitary reasons; the temperature may be very much less during the hot weather; or it may be a pleasure house to them, a sort of tenting-out period that is so much enjoyed by some of the higher animals. Who knows? The material of the summer house varies considerably, but it consists chiefly of sticks, bark, leaves, with a lining of grasses or some other material. The entrance is on the side, the nest from below resembling that of a crow.

The gray squirrels do not lay up for winter use quantities of nuts or other food, as do the chipmunks, for they do not hibernate; but when the weather is not 
severe they are abroad during the winter. However, the gray squirrel, in common with most of our other squirrels, has the habit of digging holes and hiding a nut or two here and there. It has been argued that this is an idle pastime, and that nuts so concealed in many places could never again be located by the squirrel, but it must be remembered that the sense of smell in the squirrel is very acute, probably guiding the animal far more than memory. It must be this wonderful sense of smell that directs the squirrel where to dig in the snow, securing from beneath the leaves the nuts that were buried weeks before; or that guides him to a solitary nut tree or to the grain in a barn.

This stored food constitutes only a part of the gray squirrel's winter supply. The other part he must scurry about to find. The beech trees and some others do not drop all of their nuts at the approach of winter. There still hang a few solitary nuts on each tree, and through a large beech forest the number so left is considerable. But the gray squirrel is not the only claimant for the nuts: the red squirrels and the red headed woodpeckers demanding for themselves the lion's share. The birds seem to think that these nuts are exclusively their property, and vigorously do they protest if a squirrel appears. One determined 
red headed woodpecker will sometimes put a gray squirrel scampering after a few moments, for the blows from that long sharp bill of his are severe. The squirrels, being the earlier risers, are often feasting when the birds appear, but they beat a hasty retreat before these tricolored warriors.

The gray squirrel has other enemies in feathers, such as the goshawk and the red tailed hawk. A single hawk, however, can scarcely catch a gray squirrel, especially if the squirrel remains on the tree trunk, which he probably will be wise enough to do, thus being enabled, by dodging, to evade the hawk's claws. I never witnessed an encounter of this kind but once, and certainly the squirrel was "up to the trick"; for he eluded the hawk in the most exasperating manner, chattering and barking the while in a most impudent tone, "Qua-qua-qua-qua-qua-a-a." The hawk was angry, the feathers on its head and neck being ruffled as was its spirit. At last it was obliged to retire, leaving the squirrel at his nutting. I have been informed, however, that the squirrel does not always get off so nicely, for sometimes the redtails hunt in pairs, and then the squirrel has no chance for his life.

Gray squirrels are very fond of music, says Dr. C. Hart Merriam. The doctor in speaking of this men- 


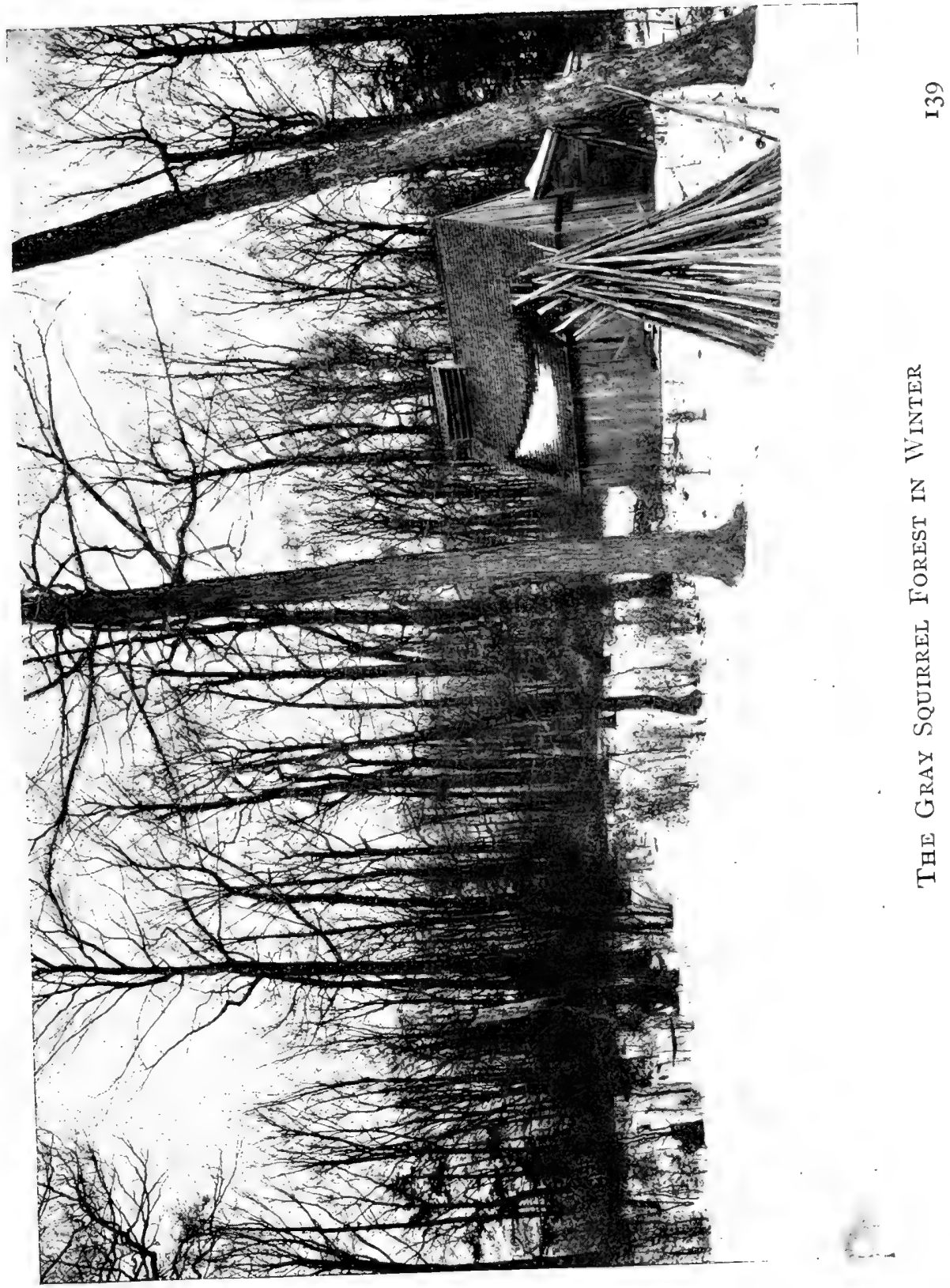



tions his experiments with some squirrels which frequented a box of nuts that his father supplied for them during the winter. As I have never myself observed this, I wish to quote from this eminent authority:

"They were extremely fond of music, and it affected them in a peculiar manner. Some were not only fascinated, but actually spellbound, by the music-box or guitar. And one particularly weak minded individual was so unrefined in his taste that if I advanced slowly, whistling 'Just before the Battle, Mother,' in as pathetic a tone as I could muster for the occasion, he would permit me even to stroke his back, sometimes expressing his pleasure by making a low purring sound. This was a Gray, and I several times approached and stroked him as above described. I once succeeded in getting near enough to a Black to touch him, whereupon he instantly came to his senses and fled. When listening to music, they all acted in very much the same way. They all sat bolt upright, inclining a little forward (and if eating a nut, were sure to drop it), letting the fore paws hang listlessly over the breast, and, turning the head to one side in a bewildered sort of a way, assumed a most idiotic expression."

From August until November we may become 
acquainted with the gray squirrel family as a whole. It is at this time that the old and the young may be seen early in the morning coming from the hard wood grove, along the old rail fence to the butternut trees at the foot of the garden. If you are on the watch, you may observe the silent troop galloping along with their beautiful tails well arched, and mounting the trees more like shadows than like wearers of fur. The frost has not yet loosened the nuts, but the squirrels are not daunted; speedily securing nuts, they sit upon the limbs with their tails over their backs, and, holding the nuts between their paws, quickly gnaw through the velvety covering and shuck to the juicy meat inside. Within an hour they go galloping back as though they had already stayed too long, silent as when they came; but if you do not see them, the telltale shucks will disclose who your visitors have been.

The old butternut trees must soon share with the cornfield their attraction for the squirrels. It was the raccoons who first discovered that green corn was in season, but the squirrels claim their part, and on some fence rail or post you may find a daintily stripped cob, left there as a reminder that the squirrels too are to share in the increase. Better still, perchance, you may wander by and surprise the reveler at his feast. 


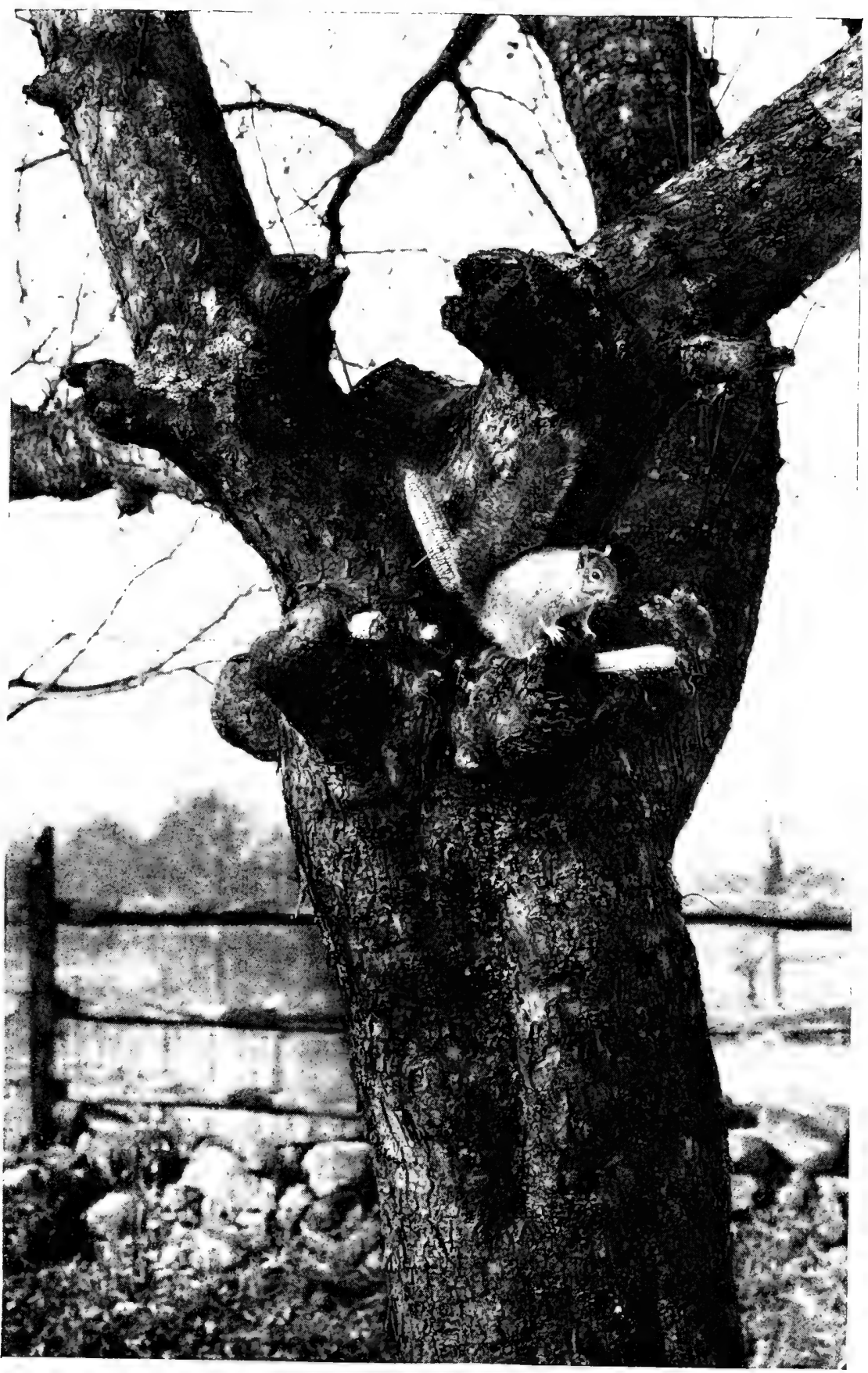





\section{The Gray Squirrel}

There is an old orchard that I have known for years, where the gray squirrels have a regular playground in the autumn. It is connected with a piece of woods by a fence, and this fence is the grand highway of all the squirrel tribe. During their earlier visits to the orchard they come and go silently as if on wing. When most of the apples are gathered, and the frost has touched the leaves, leaving them sere and russet, there is in the atmosphere a crispness which has awakened the rollicking spirit in the gray squirrels. No longer do they follow the old fence, but cut across lots, chasing each other in and out, now on this side, now on that, on the way to the tree tops in the orchard. Here, while searching for food in the first light of the morning, they frolic, leaping from branch to branch, and chattering and scolding like a lot of magpies. If left undisturbed, they remain until the sun is more than an hour high, when they begin to retreat to their forest homes in the same jubilant manner in which they came. On reaching the forest, for another half hour they race through the tree tops before retiring.

If perchance, having found your way into the forest before them to await their coming, you disturb them in their frolic, they will instantly vanish from sight behind the tree trunks or the shielding branches. 


\section{46 The Gray Squirrel}

You walk around a tree on which you saw a squirrel a moment before, and you set in motion squirrels about you; they move as you move, keeping ever a tree trunk or a limb between you and them. If you are accustomed to the ways of wood folk, you will sit down and keep your eyes and ears open. In the stillness you will detect, after a little time, a slight shaking of the leaves, or catch a glimpse of a gray shadowy coat now flecked by the sun, but almost invisible against the moss and bark of the maples. These shadows are the squirrels, furtively seeking their retreats. You may be resting under a tree in which there is a wary old gray squirrel, still some distance from his home. Do not for a moment think that he will leave the protection of the large limb on which he is reclining, and expose himself to view. There he will lie for hours until, weary in well-watching, you leave him that you may seek some less wise one.

During the remainder of the morning and until late afternoon, the squirrels stay in their homes. Then they are out again for their evening meal, but without the same joyousness with which they greet the dawn.

An early morning hour with the gray squirrels is as fascinating as it is to surprise them upon their return from the old orchard. It requires a morning with a heavy dew and absolutely without a breeze. 


\section{The Gray Squirrel}

Before daybreak you must cross the threshold of their forest home, and resting upon some log or mossy knoll near their exit, await their coming. Your ears will serve you better than your eyes. At the first rosy dawn in the east, the squirrels from the outlying districts mount into the tree tops and begin their travel toward you. Their coming is first made known by a slight noise on the ground, but if you try to locate them by ear, you may be misled; for where everything is so still, a slight sound may be heard many rods away, through the large timbered forest. Before you have determined the cause of the first sound, or before you have fairly located it, another is heard in a different direction. You are all attention! A regular tattoo of these sounds is now heard on the forest floor, caused by the tiny showers of dew shaken from the leaves, as the squirrels leap from the end of one slender branch to the next. Soon your eyes begin to take part in the scene, as the graceful forms scurry through the leafy arches overhead. In a little while the gray troop have passed on their way to the orchard.

If our homes are conveniently situated, the gray squirrels will visit us during the winter and spring. If we tempt them with a little food, they will come both morning and afternoon, when the weather is not 


\section{48 The Gray Squirrel}

too cold or stormy. This step taken, it is easy to become quite intimately acquainted with our little friends in fur. Out of a company of five grays that were accustomed to visit a certain tree, where food was placed for them, there was one larger than any of the others, and supporting a most magnificent tail. He became very tame, and appeared to be so vain over his fine appearance that I photographed him one morning while he was having breakfast.

For the protection of these beautiful mammals we have laws; but all the laws in Christendom, however well enforced, cannot prevent animals that naturally make their homes among the larger timber from leaving when the forests are destroyed. It is a pity that, with our boasted civilization, there seems to be such a wanton destruction of our trees. It may be the heredity of habit that drives us madly on to denude the hills and mountains, thus leaving them bare, unsightly, and untenanted. The result is invariably the same, to dry up our springs and streams and to drive from us the gray squirrels and other animals. If this continues for another twenty years, as it has for the past twenty, the gray squirrels will be counted among our rare animals. In Central New York I have seen but one black squirrel in the last ten 


\section{The Gray Squirrel}

years. West of the Great Lakes both grays and blacks are quite plentiful, but it seems that they too are now dwindling in number, and will finally be entirely exterminated. 


\section{THE RED SQUIRREL}
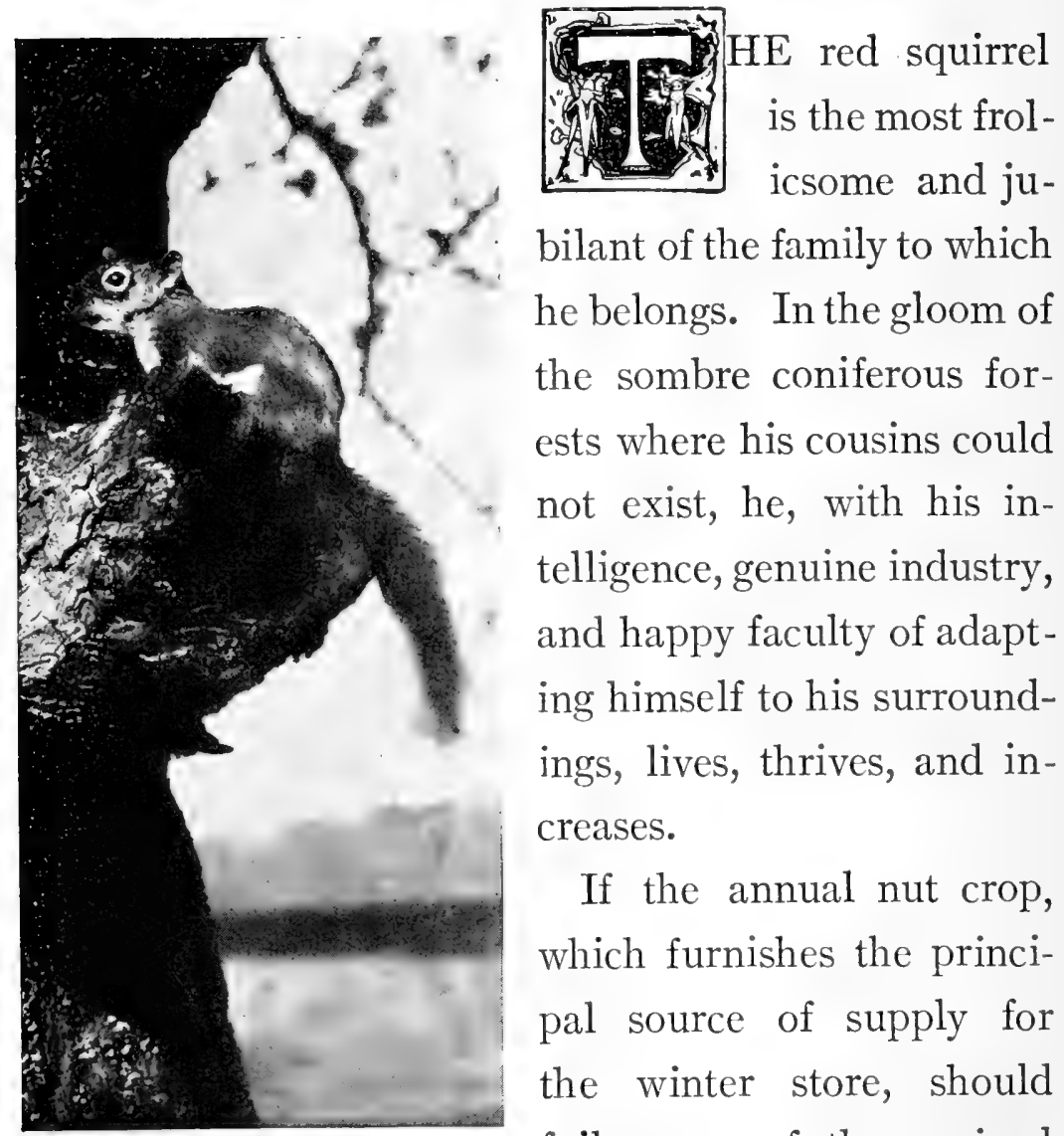

bilant of the family to which he belongs. In the gloom of the sombre coniferous forests where his cousins could not exist, he, with his intelligence, genuine industry, and happy faculty of adapting himself to his surroundings, lives, thrives, and increases.

If the annual nut crop, which furnishes the principal source of supply for the winter store, should fail, many of the squirrel family would be forced to migrate; not so, however, with the red, for he can keep the "wolf from the door" by subsisting upon the buds, seeds, and 


\section{The Red Squirrel}

roots of various shrubs and trees which he finds among his haunts. Even mushrooms are eatenand just how a red squirrel knows the difference between the poisonous and the non-poisonous varieties has always been a mystery to me, but I have never seen any but the edible ones collected by the squirrels; nor have I discovered even a toothmark upon the others. Mushrooms decay quickly if not gathered at the proper time; and the red squirrels, who know this as well as we do, harvest them accordingly. Then there are the barberries, chokeberries, greenbrier-berries, and partridge berries which they can add to their store; but these are not exclusively the red squirrel's, for the bluejays, partridges, quail, and mice come in for their share. The chickaree, as the red squirrel is often called, also makes a point of storing cones from the pine, spruce, and hemlock, the seeds of these being agreeable to him when the branches are coated with ice, and the snow is deep through his forest home. He begins the harvest of the cones quite early, when the other crops are not pressing, cutting them from the trees and letting them fall to the ground, where they dry within a few days. The squirrel does not gather these cones without this preliminary process of seasoning, for if not properly cured the seeds would mold. 
But the food question is not settled for the chickaree even after his stock is gathered-there are unprincipled neighbors watching to take advantage of his thrift. He has little trouble from his own kind in this respect, for each red squirrel is supposed to have a certain territory that belongs to him, and trespassers upon another's preserves are promptly chased off; but there are other hungry wood folk not so easily disposed of, such as the thieving bluejays, which know neither bounds nor limits and which are ever on the alert for a free lunch. Consequently the squirrel needs to have various storehouses for his food. Knowing that the jays do not care for mushrooms he places them conveniently on a limb of a neighboring tree: but the careful little provider would never think of leaving his corn and nuts in such an exposed place; these he hides in a cavity of a tree or in a hole in the ground, the latter being by far the safer place.

Annoying as the bluejay often is, he sometimes serves as a friend to the squirrels and to other wood dwellers as well. The red squirrels, being a constant target for the gunners, are very shy, and the jay often sounds an alarm-note when the hunter is some distance away, thus warning the chickaree in time to scamper away and hide himself until the danger is 


\section{The Red Squirrel}

past. This bird has caused the hunters to lose many a good shot, not only at small game, but more particularly at members of the deer family.

But to go back to the chickaree. He is an expert on the subject of nuts, not only in selecting sound and good ones, but also in the manner and certainty with which he gets at the kernel. Concerning this accomplishment John Burroughs writes as follows: "There is one thing that the red squirrel knows unerringly that I do not (there are probably several things); that is, on which side of the butternut the meat lies. He always gnaws through the shell so as to strike the kernel broadside, and thus easily extract it; while to my eyes there is no external mark or indication, in the form or appearance of the nut, as there is in the hickory-nut, by which I can tell whether the edge or the side of the meat is toward me. But examine any number of nuts that the squirrels have rifled, and, as a rule, you will find they always drill through the shell at the one spot where the meat will be most exposed. Occasionally one makes a mistake, but not often. It stands them in hand to know, and they do know. Doubtless, if butternuts were a main source of my food, and I were compelled to gnaw into them, I should learn, too, on which side my bread was buttered." 


\section{54 The Red Squirrel}

Although the chickaree is so good a provider, food sometimes becomes extremely scarce in the spring, and his hunger drives him to drink. He does not slake his thirst at the mountain stream, however; he taps a maple tree and later on a birch. With his sharp chisel-like teeth he makes an incision in the bark, either upon the tree trunk or upon the limb. If a little cavity is so situated that the sap collects in it, it pleases him all the better, for the task is lighter, and then he has more time to attend to the affairs of his neighbors,--and a most inveterate gossip is the red squirrel! I wonder if the sapsucker taught him to tap the trees, or did he teach the sapsucker? The Indians probably learned this from one or the other, or from hoth.

As to homes-sometimes the chickaree builds in a tree top a summer house similar to that of the gray; but unlike the gray he occasionally passes the winter in his summer home, for he seems to be able to endure severe cold weather. Twenty or thirty degrees below zero does not appear to inconvenience him in the least, and even at this low temperature he will play and frisk gaily about in the light snow. He makes the most of the few hours of daylight, being abroad at nearly all times of the day, but retiring early. In summer, however, especially in the busy 


\section{The Red Squirrel}

\section{55}

nutting season, he keeps late hours; in this respect resembling his smaller cousin, the flying squirrel.

The red squirrel combines qualities so dissimilar, that he is clearly the enigma of the forest. His wonderful inquisitiveness, his exasperating insolence, coupled with all disregard for the ordinary civilities of the wood dwellers, would stamp him "the black sheep" of the flock. If you disturb him in your walk, and your dog makes a dash for him, he mounts the nearest tree, and from a limb just out of reach he literally boils over with rage and indignation, jerking his tail and stamping the limb furiously, calling "chickaree, chickaree." He barks and spits, and says things in squirrel language that probably would sound very dreadful in English; he makes little dashes first this way, then that, as though he intended to come down the tree and run that dog from the premises. He has no more respect for a man than for a dog, and if you sit down and remain motionless, he may either pay no attention to you at all, or his insolence may know no bounds, so fickle and changeable is his disposition. If your presence is not agreeable to him, he will approach nearer and nearer, calling loudly, and if you quietly persist in remaining where you are, he becomes a small fury of impudent rage. Yet, with these objectionable traits, his intelligence, 


\section{The Red Squirrel}

his wonderful perseverance, his industry, and the cleverness displayed in his various actions cause him to be tolerated, even though he is an acknowledged nuisance.

Many claim that the chickaree is the bird's most deadly enemy, destroying both eggs and young: others are equally positive that the red squirrel does not meddle with nesting birds; that he visits the nests very often, but that this is out of pure curiosity and nothing else; that the old birds tolerate him and make no outcry when he is near their nests, thus proving that he is not a destroyer of their young. I do not precisely agree with either, for circumstances have very much to do with it, and to say that the red squirrels as a whole do or do not rob birds' nests is a very sweeping statement. There are probably both innocent and guilty red squirrels, as far as robbing birds' nests is concerned. In other words, I believe it to be a habit, formed like any other habit that an animal may have, or that we may have. I do not believe that red squirrels are nest-robbers, any more than a hen naturally eats hens' eggs. Occasionally a hen develops the habit of eating her own eggs and all others she may find, but it would be unfair to accuse all hens of this unnatural practice. If I understand the nature of the red squirrel, he will, if forced 


\section{The Red Squirrel}

by hunger or some other cause, eat birds' eggs or even young birds. Further, one squirrel may imitate another, and therefore in some particular localities the red squirrels may trouble nesting birds, while in another they do not. Hence arise the difficulties for unsuspecting readers, one eminent authority saying one thing, while another says exactly the opposite. Each may be right for his particular locality, but one should not judge that it is a universal habit of the species unless he has more knowledge on the subject than most men take the trouble to possess.

Those who have tented in woods far removed from man's influence must have observed the ungovernable curiosity of the red squirrel. Within ten minutes after your camping outfit was landed, he was chattering at you from the tree tops. Before you had the centre pole in place, he had descended to the lower branches. If he considered you a 'squatter' upon his territory, his language indicated it; but if he was pleased, his every action showed his approbation. You never made your camp fire so early, or replenished it so late at night, that the chickaree was not before and after you. Many a time I have been awakened in the early morning by the repeated calls and chuckles of this clown of the forest; nor was he always satisfied 
in remaining on the outside of my tent, for if I did not appear at what he believed to be the proper time, he might surprise me by coming inside.

His preparation for coming into the tent must have been a severe strain upon his nervous system. He was on every side of the tent except below it, calling and chattering in the most hilarious manner, seeming to say, "I'll come in; I'll come in." When he had finally settled upon a place of entrance, instead of entering it in a stealthy manner, he would rush screaming at it, like a bull at a red flag, stop before it for an instant, and then scamper away and up a tree. Several such attempts were usually made before the chickaree permitted even his head to enter. This accomplished, he would dart back and hold a council of war with himself from a low branch over the tent or ridge pole, apparently trying to determine just how much of his body should be allowed to enter on the next assault. Sometimes a half dozen attempts would be made before he really got inside. But once in, this boldness would seem to impress him with the fact that it was something unusual in him or in his family, and he would turn tail about, rushing out and up a tree, as if a weasel were in hot pursuit. A nut now dropped near the entrance would seem to assure him that you were 


\section{The Red Squirrel}

really his friend, and after another attempt he would get inside again. "The ice once broken," he would visit you regularly during your stay, accepting food of almost any kind. A few weeks of this, and you become very much attached to the mischievous little rascal, and after camp days are over, the recalling of his escapades is a pleasant memory.

This same curiosity that endears him to the campers makes him a terror in the region of the trappers. In this connection Dr. C. Hart Merriam writes:

"From an overhanging limb he looks on with unfeigned interest while the trapper arranges the bait for the marten or fisher; but a moment later he has sprung the trap, and is chippering with exulting derision at the result. He is often caught, it is true, but half a dozen others are always ready to take his place, and it affords little satisfaction to the hunter, on his lonely rounds through the snow-clad forest, to find a worthless squirrel in his trap, instead of the valuable fur for which it was set."

The red squirrel has several enemies, but of these the most deadly are the hawk, the owl, and the weasel. The weasel is the most relentless of all, and by his sense of smell pursues the squirrel through the tree tops. The squirrel is by far the fleeter, but, for some reason not known, he apparently goes crazy when he 


\section{I60 The Red Squirrel}

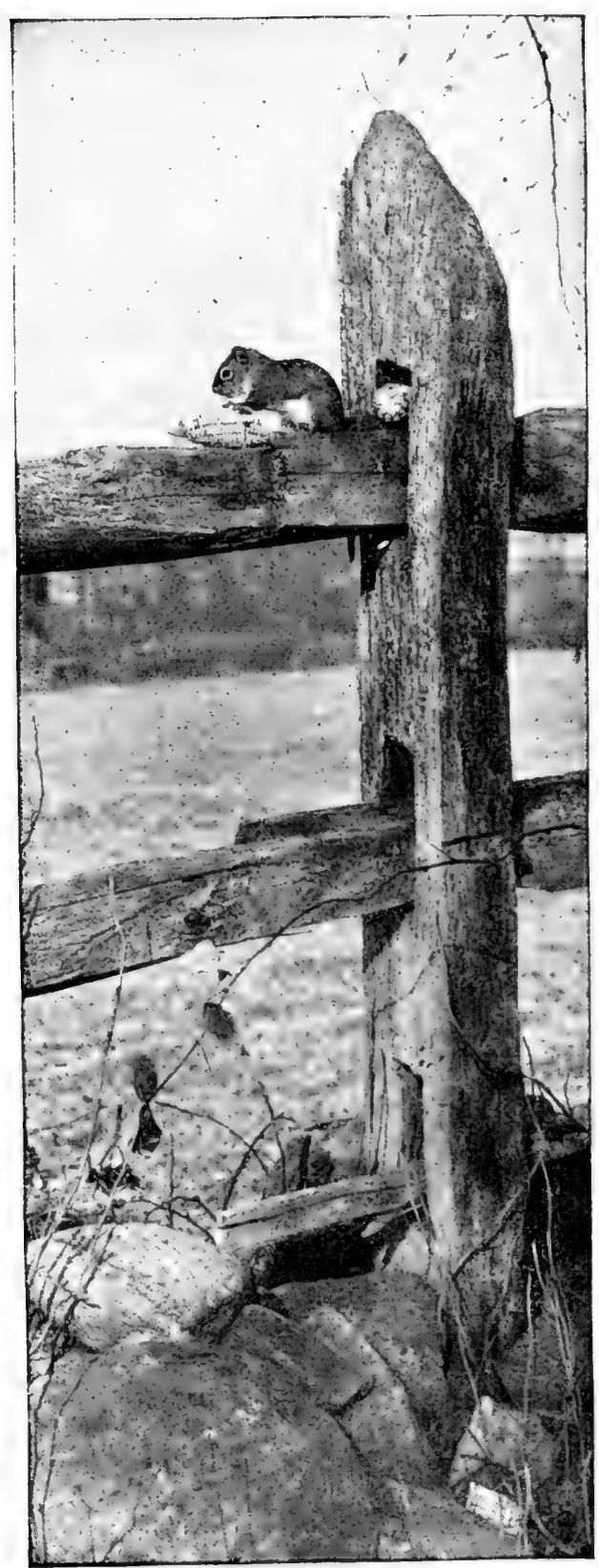

discovers the weasel on his trail, and rushes pell-mell among the trees, up and down, crossing and recrossing his trail, and finally, hiding among the branches or taking to a cavity, he awaits the coming of the weasel, which means sure death.

The red squirrel's highways are not confined to the forests, for he uses fences connecting the forests with the orchards. He often comes to the farm buildings, not infrequently taking up his residence there for the winter; the corn and grain 


\section{The Red Squirrel}

houses must indeed be tight if they are to keep him out. These various highways are his racecourses, for he is very sportive with his kind. Often you may see one chasing another over an old rail fence or through tree tops. The chickaree being a very expert climber and swift runner, the race is exciting indeed. It is wonderful what long leaps these squirrels make, and upon what slender branches they are able to travel. The reds are probably the fleetest and surest-footed of the squirrel family. Most of these races take place between the males, from May until September. I never saw such a race as I observed last year in August, in the tops of four large apple trees. Three squirrels took part in it, and it was plainly a game of tag through the tree tops, resembling the old game of cross-tag. One chased the others, the pursued keeping close together; sometimes, however, they would become separated, and the one not being chased would rest a little until the other two came his way, when he would join in, and away they would speed. This fast pace was kept up for perhaps ten minutes, then a short pause, and then the game began again, this time with a new pursuer. I watched them at least a half hour, and then all of a sudden they left the tree tops for the old rail fence, and raced back to the forest. 


\section{THE FLYING SQUIRREL}

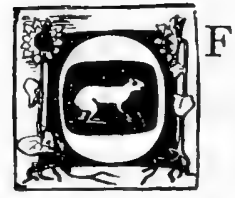

all the mammals that it has been my pleasure to know a little about, there is none other so confiding, so gentle, and so graceful as the flying squirrel. There is nothing striking about him in the way of color, although the dense silky fur of a grayish brown above and white beneath, rivalling in softness and beauty that of the chinchilla, renders him one of the most beautiful of our squirrels. The eyes are very prominent, large, dark, and peculiarly expressive.

The flying squirrel is a specialized type of his family, possessing a peculiar hair covered membrane of skin on each side of the body between the fore and hind legs, and attached to both as far as the wrist and the ankle. When in a sitting posture or in the ordinary movements of the body, the flying membranes are drawn, by their own elasticity, close to the body, like little curtains, and do not detract from the delicate proportions of the graceful animal. But when the squirrel is about to fly it spreads its "wings" 


\section{The Flying Squirrel}

and from the summit of a tree springs lightly into the air, and then glides silently away, always in a slightly descending direction, until a movement, probably of

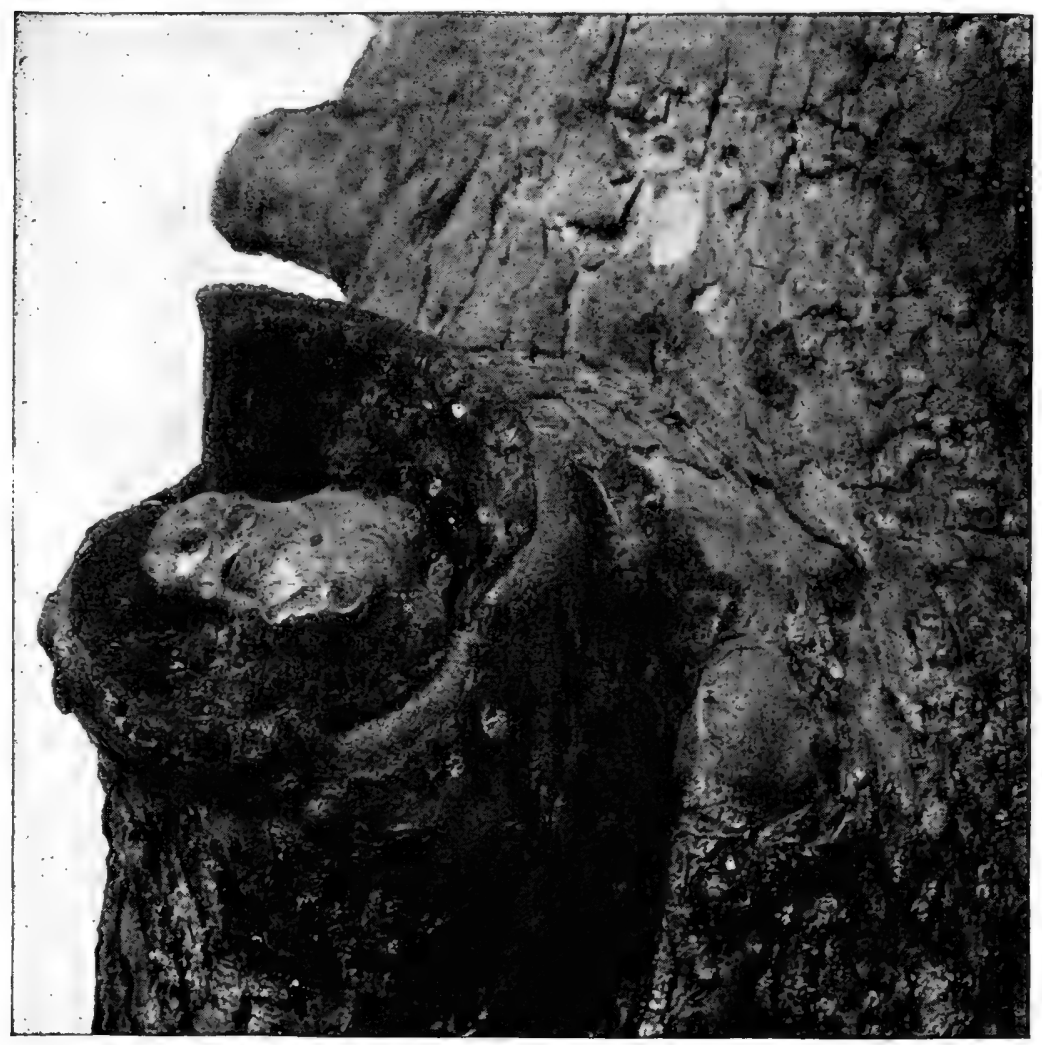

FLYING SQUIRREL

both body and tail, inclines it upward, and it alights gently upon the object for which it set out. The tail, being thin and flat with closely set silken hairs, probably serves a double purpose on these short flights,- 


\section{I64 The Flying Squirrel}

that of rudder and parachute. I do not mean by this that the tail can in any way turn the animal from a straight line, except that probably by bending it downward, and at the same time elevating the chin, it brings the body to a convenient angle for alighting upon an upright object. The distance to which the flying squirrel can "fly" depends entirely upon the elevation from which it starts. The angle of descent is ordinarily from twenty to thirty degrees, although the desire of the animal, together with the direction and force of the wind, probably commands an extreme range of from forty degrees to a nearly perpendicular drop. The usual mode of travel from place to place, if trees are convenient, is sailing from the top of one to the base of another, then running up this and again sailing. It is surprising how quickly one of these little fellows can travel a quarter of a mile.

Do not imagine, because you have never seen a flying squirrel other than a mounted specimen, that they are rare; in reality they are quite plentiful, but being thoroughly nocturnal they are seldom seen. Now if you really wish to know the flying squirrel at home, go into a grove of large maples, beeches, or chestnuts on a still moonlight evening in September, find a comfortable seat and remain quiet for a little while. Should it so happen that you do not see a flying 


\section{The Flying Squirrel}

squirrel you will be amply repaid, for other nightloving animals are abroad and they are as interesting as those which work and play by day. If you have not been accustomed to this rare treat, your eyes will be busy with shadowy glimpses and your ears with strange new sounds. There will be the patter of light footsteps on the ground, the squeaking of unseen creatures, the frantic hurry of some being pursued, the lonesome note of a distant bird, or the monotonous call of the whip-poor-will; these and a myriad of other sounds will fill the air, giving abundant evidence of the animal life that is astir. You listen! There is a sound like that of a nut dropping from a tree. Again you listen, and a slight rustle of eaves is heard overhead, as a shadowy form glides through the air and, alighting upon the bole of a tree not ten feet away, scampers up the tree very squirrel-like. The sprite has scarcely started before another alights at nearly the same place, and hastens after the first. It is not unusual for three or four flying squirrels to start from the same or neighboring trees, and at times there will be various lines of flying squirrels crossing and recrossing each other.

Consider yourself fortunate!. You are among the homes of the flying squirrels and you have seen them at their evening play. Frolic and amusement occupy 
the greater part of the waking hours of the flying squirrels, and old and young enjoy it alike. Even during the "business hours," when the storehouses must be filled with nuts for winter use, the same rollicking spirit holds sway over this squirrel band.

The flying squirrels live in communities, but during the winter months a half dozen or more occupy the same cavity in a hollow tree. Even in the storing of food for winter, several may unite in collecting a general supply. The storehouse may be in the same cavity as the living quarters, or in a separate one in the same tree, while it is occasionally in a tree some little distance away. The food stored consists of nuts of various kinds; while in their season buds and fruits are much enjoyed.

Wood choppers very often find the storehouses of the flying squirrels. I saw a man take six quarts of beechnuts from a cavity in a large maple tree in the month of January, and from the same tree we counted eight escaping flying squirrels. In this instance the squirrels and beechnuts were found in separate cavities.

We captured two of the squirrels, a male and a female, and the man took them home for pets. In a few days they were perfectly tame, and at nightfall they would come from their cage, and play about the house, apparently as contented as though they 


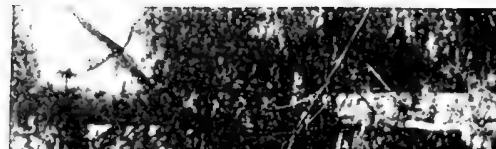

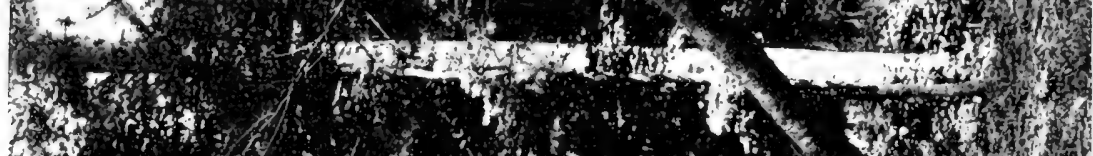

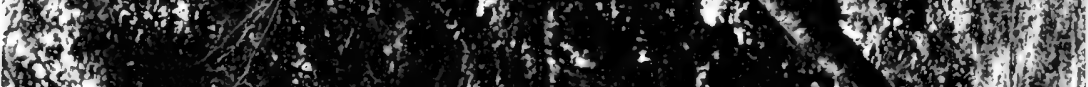

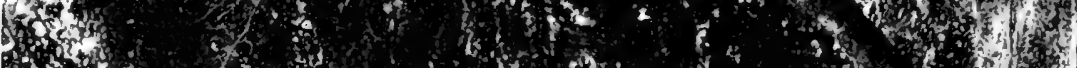
ty

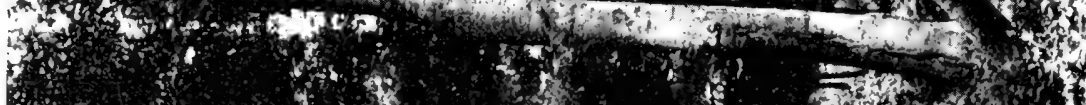

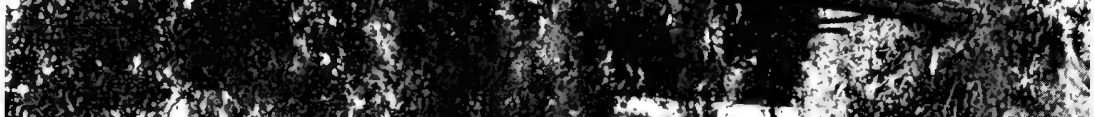

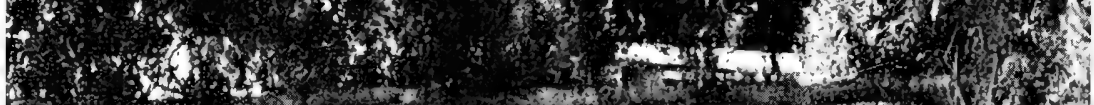

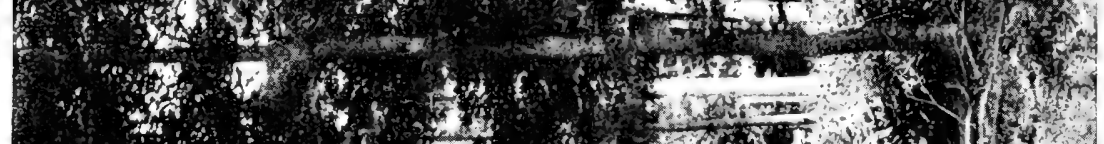

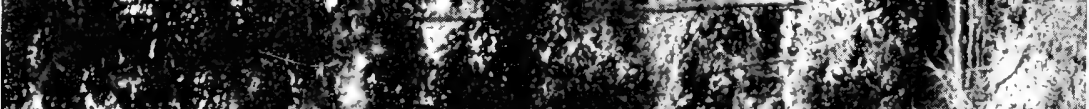
Gow

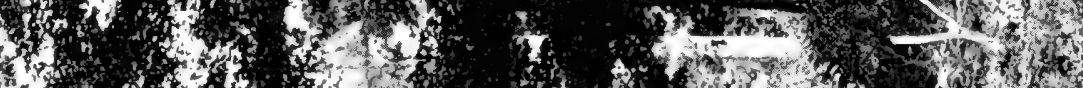
1.

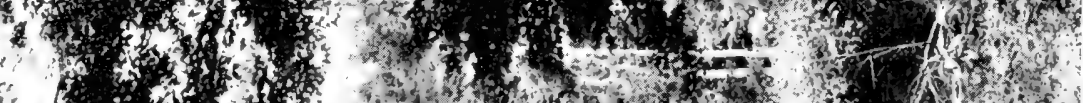

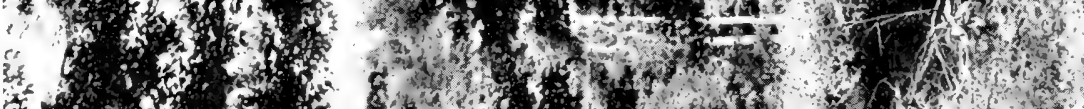

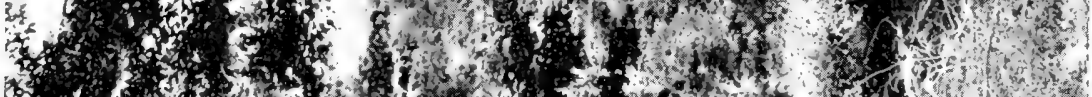

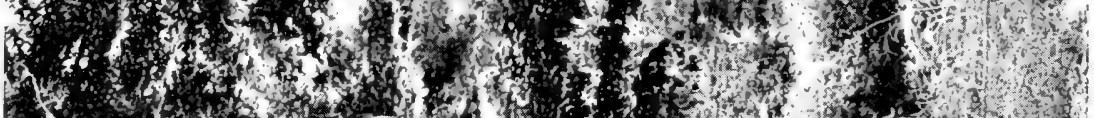

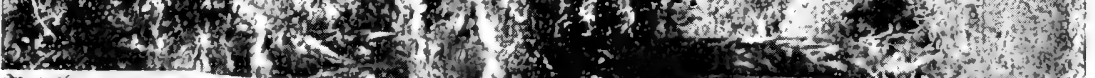

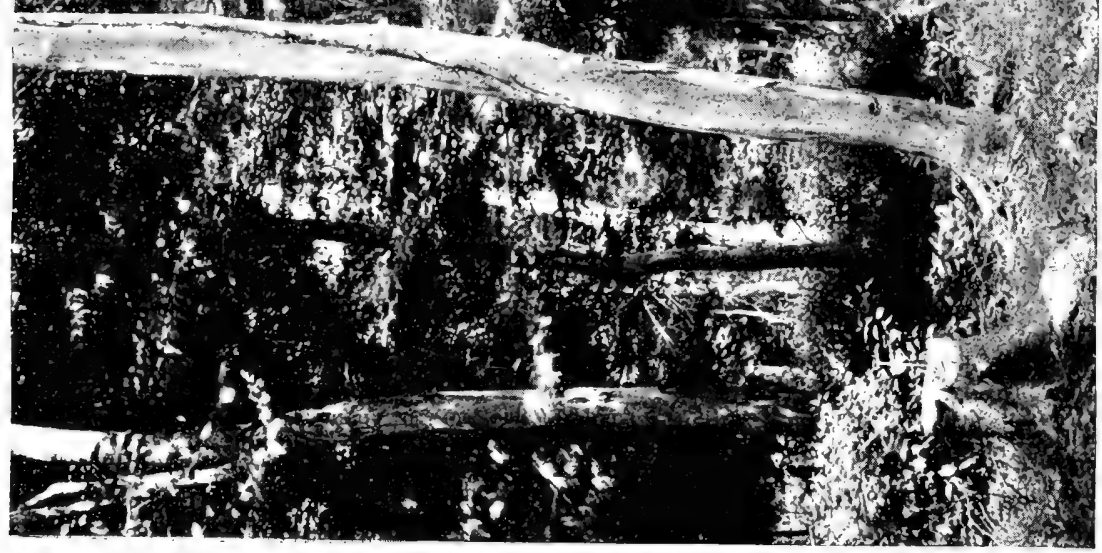




\section{The Flying Squirrel}

were in their forest home. It was found, however, that care must be exercised, for the squirrels seemed to enjoy trying their teeth on almost everything except iron. In the spring comfortable quarters were made for the squirrels in the woodshed attic, with just enough of the wild about to remind them of their old home. At the rear of the attic stood a large maple tree, the boughs of which touched the house; the old tree had but one cavity, but it was supplemented by a woodpecker stub brought from the grove near by, and fastened in an upright position about thirty feet from the ground. It did not take the squirrels long to find an opening at the end of the attic by the old tree, and thus their playground was considerably enlarged.

In the old stub the first litter was born, and as soon as these young squirrels were large enough to enjoy night frolics the attic became their playhouse.

The distance from the old tree to the edge of the forest, where the beechnuts and chestnuts were plentiful, was only twenty rods, and it was an easy twenty rods, for the squirrels made use of a fence and an orchard.

By the time the frost had touched the leaves in the forest, leaving them russet, red, and gold, the old instinct had conquered the few months of civilizing 
influences, and the whole family of our flying squirrels must have visited the forest nightly, judging by the quantities of nuts that were stored in boxes in the attic and in the stub of the old maple tree. The family lived happily together that winter, but the next spring most of the young ones sought homes of their own, most likely in the forest near by. Other young were reared in the attic and the old tree, but the following August they all mysteriously disappeared, both old and young, probably obeying some migratory instinct. It is worthy of note that the autumn following their disappearance the nut crop was a complete failure in that immediate vicinity. Is there any connection between the two circumstances? If so, flying squirrels are as wise as they are beautiful.

Besides nuts, buds, and various roots the flying squirrels, both those born in captivity and the wild ones, are particularly fond of meat. Without doubt they catch sleeping birds and also destroy eggs and fledgelings. By reason of this taste they have proved themselves to be quite a source of annoyance to trappers, destroying the bait intended for larger game, springing the traps, and of course many times being caught. Because of this interference trappers sometimes attempt to reduce the number of flying squirrels 


\section{The Flying Squirrel}

on the route along which they intend to trap during the fall and winter. This is done just before the trapping season opens, two trappers usually hunting together. One is armed with a heavy club, and the other with a shot gun. They go over the course searching for trees and old stubs that are likely to contain flying squirrels. When a suspicious looking cavity is observed the hunter with the gun stands ready, while the one with the heavy club strikes vigorously upon the butt of the tree. If the cavity is the home of a flying squirrel, it is quickly made known by his appearing at the entrance of the cavity, and frisking out upon the trunk of the tree, where he is easily shot by the hunter in waiting. Sometimes as many as six have been killed in as many minutes, all coming from one cavity.

Although the flying squirrels cause the trappers many a weary tramp, they all agree that these little animals are among the most beautiful creatures of the forest.

Pet squirrels are very common, but they are usually of the red or gray varieties. I have had red, gray, and flying squirrels, but to me the flying squirrel is by far the most lovable. By nature he seems more gentle and affectionate; even a wild one will seldom 


\section{2 \\ The Flying Squirrel}

nip your finger when taken in the hand, while a red or gray will bite fiercely.

My red and gray squirrels were quite tame, but they always lacked the complete confidence which was so apparent in the flying squirrel. The latter would nestle in my hand, crawl into my pocket or up my sleeve, or even go to sleep in my vest-front, evidently enjoying the warmth of my body. This natural affection and love of warmth are probably the reasons why several flying squirrels live together during the winter.

My flying squirrels occupied a large cage with a wheel attachment, the revolving of which seemed to afford them much amusement. Sometimes both squirrels would revolve the wheel together at a very high rate of speed, and then, clinging to the wires, ride round and round until the wheel nearly came to rest. Then both would put it in motion, often repeating the performance for half an hour at a time. Again they would vary the entertainment by one doing the work and the other the riding. In fact they were apparently upon the lookout for new methods and combinations of revolving the wheel, and thus we were treated to a continuous and varied performance.

A single incident is sufficient to illustrate their 


\section{The Flying Squirrel}

love for a new amusement. One evening I placed in their cage two small apples. Upon awakening the squirrels discovered the apples, and one of them began to nibble at the fruit. The other squirrel approached the one eating the apple, who, to avoid being disturbed, immediately carried the apple into the wheel to complete his feast. In some manner the wheel began to revolve, and the bounding of the apple on the wire bars so amused the squirrel that he forgot his hunger, and began a play entirely new to him. Soon the other squirrel was attracted by the lively noise produced by the apple striking on the bars, and he joined his comrade in the wheel, and a rollicking time they had of it, jumping and bounding over the apple, while the wheel was rapidly revolving. This was the beginning of what proved to be great sport for the squirrels. After this it was not unusual for them to have two or three large nuts in the wheel, and when the wheel revolved somewhat of a medley resulted.

In all their varied movements in the wheel they were marvellously quick and graceful. Their motions were at times too rapid for the eye to follow. Some idea of their agility may be obtained by a description of the passage from the cage into the wheel; to go into the wheci the squirrels had to pass through 


\section{74 \\ The Flying Squirrel}

a hole in one end of the cage, then through another hole in the end of the wheel, the holes being about two inches in diameter. By means of a light weight on one side, the holes were opposite only when the wheel came to rest. During its rapid revolution by one of the squirrels, the other would pass in and out with perfect ease. This is most wonderful, as it could have been but a fraction of a second when there was sufficient space for the squirrel to pass. Yet I never knew of either of them being caught.

For two years the squirrels occupied the cage, and then other quarters were made for them in a tree near the house. There they remained during the spring and summer, but as the nutting season came the forest depths proved irresistible, and our little friends vanished into its enticing shade. 
PART II

BIRDS 


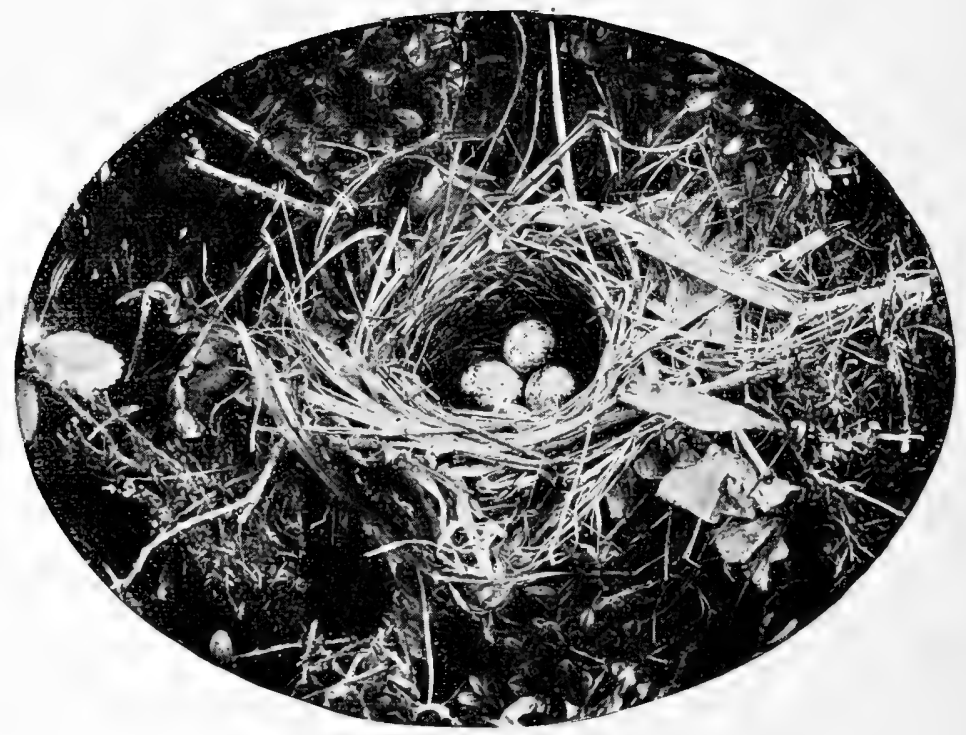

Nest and Eggs of the Song sparrow

66

A bird's nest. Mark it well, within, without, No tool had he that wrought, no knife to cut, No nail to fix, no bodkin to insert, No glue to join; his little beak was all. And yet how neatly finish'd! What nice hand, With every implement and means of art, And twenty years' apprenticeship to boot, Could make me such another?"

HURDIS。 


\section{THE MIGRATION OF BIRDS}

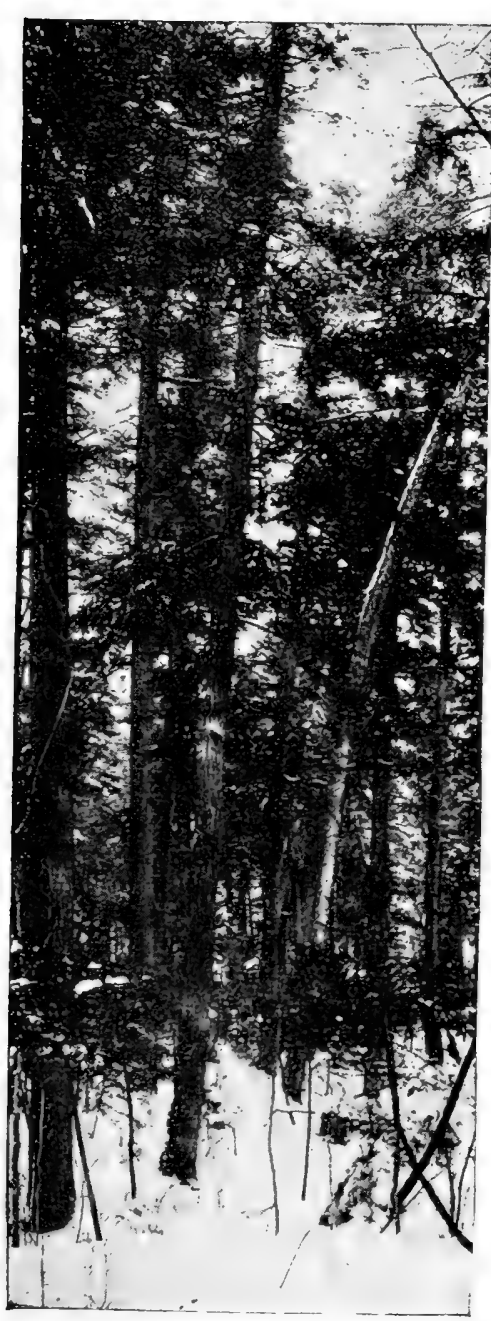

IN WINTER

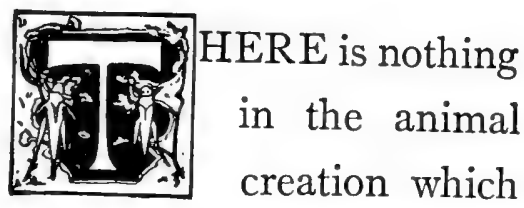

has excited more wonder and speculation in mankind than that mysterious going and coming of birds, called migration. For ages past it has been going on; Aristotle quoted, "One swallow does not make a summer," and Homer compared the noisy march of the Trojons to the clamorous flight of a flock of cranes migrating southward.

That young birds are suddenly seized with an uncontrollable impulse to start for warmer regions, is some- 


\section{I78 The Migration of Birds}

thing for us to think about. This question concerning the cause of migration is often answered to the satisfaction of many by the statement that "The old birds lead the way, and the young follow." If this is a logical answer, how are the believers of this theory to account for the fact that sometimes the young of certain species go first; also how would they account for the restlessness during the migration season of caged birds that were taken from the nest before they could fly?

The Origin of Migration. Why do birds migrate? This is a fascinating subject and one much indulged in by bird students, probably for reasons known to themselves, but apparently because each has a pet theory that the others cannot disprove. General statements concerning migration may stand approved, but when we consider the details of the subject, it is easy to ask questions which it is impossible to answer. Whatever theories may be advanced in explanation of migration, it should be remembered that birds are very conservative and habits once formed may be maintained for ages, though they ceased long ago to be useful. Therefore in considering the origin of migration we cannot expect to find it wholly in the present condition, but we must at least go back to a time before the Glacial period. 


\section{The Migration of Birds}

Previous to the Glacial period, tropical conditions prevailed in the north temperate zone; hence temperate climate must have extended nearly to the north pole; but even here probably a sufficient difference existed between summer and winter to render a certain degree of migration necessary. These conditions must have continued for centuries, until the coming of the Glacial period, which, brief as it was, geologically speaking, wrought wonderful changes in the zoological world.

Let us stop for a moment to consider how significant a factor the Glacial period in North America must have been in bringing about this slow but sure change in the habits of our birds. From some point in the north which has not yet been determined the icefield began to stretch slowly southward, until Canada was buried; and finally a portion of the United States, including the region of the Great Lakes eastward to the Atlantic Ocean, southward into New Jersey and Pennsylvania, and westward to the Missouri, was also completely covered by the ice sheet. Similar ice sheets prevailed in northern Europe and Asia. It seems probable that the migration of birds was one of the great results of the Glacial period. Had the Glacial period never occurred, and had the temperate conditions of the north frigid zone remained as they 
were, it seems more than likely that the long arctic night, when for three months the sun does not rise above the horizon, alone would have taught the birds to migrate at least a few hundred miles north and south. These theories have an interest, and as we ponder over them we may get some light upon the subject; but let us remember to state them as theories, much as we should like to prove or disprove them.

Some theorists, without attempting to see so far back into the early conditions causing the great annual pilgrimage of our birds, argue that the desire for a genial climate, where food is plentiful, can alone account for this great phenomenon. Another theory, urged by many, is that the annual nesting season is sufficient to cause migration. The believers of this argue largely from the conditions existing to-day. Birds, and in fact most animals, have an innate desire for seclusion during the period of reproduction, and will seek some retired locality in which to bring forth their young. This pertains not only to those birds which winter in South America and nest in Canada, for tropical birds also will seek secluded places within their own zone; and the seclusion habit concerning the eggs and young is very noticeable in our turkeys and Guinea fowl as well. Among the fish, the salmon is most noted for its long journey from the 


\section{The Migration of Birds}

ocean to the headwaters of some river, where the eggs may be deposited in safety. The distance is remarkable in the case of the quinnat salmon. It ascends the Yukon to Caribou Crossing, two thousand two hundred and fifty miles from the ocean! It is well known that seals migrate regularly to certain islands, known as breeding grounds, where the young are born. These additional observations are helpful in the study of migration of birds, and I believe they strengthen the supposition that the existing conditions are the results of changes that have been slowly progressing through past ages.

Whatever may be the true theory, there is ever an increasing charm about the study of migration, as we note from year to year the comparative regularity with which the birds come and go. It is not, as some believe, a general helter-skelter movement among the birds, but quite the opposite; it seems to be a regular part of bird life, and they go about it in a businesslike manner, as though they knew there was something definite to be done.

The extent of a bird's migration must necessarily depend upon its food; a so-called resident bird, like the crow, generally changes its food with the season. Some birds depend upon fruit, others upon insects. The insect-eating birds must migrate the farther of 


\section{82 The Migration of Birds}

the two. Many of our birds winter in the Gulf States; the swallows, swifts, and bobolinks making more extended migrations, varying from Central America to Brazil; while some species of snipe and plovers make the longest migrations, wintering in southern South America and nesting within the arctic circle.

Of the many phases of migration, there is one which completely baffles the most adroit students of ornithology; that is, how young migrants find their way when not accompanied by the old birds. The only rational reason that we can assign is that the birds have some instinct or faculty which directs them. It may be the "homing instinct" reversed, for certainly the only homes the young birds know are the nesting places. Some believe that the same faculty guides the young birds southward that the dog or cat uses in finding its way home after being transported a considerable distance. Probably the young birds in migrating southward have no particular spot in view, and a few hundred miles east or west would make no difference, while on the northward trip it has been proved that they return to the same barn, chimney, or tree. Who can tell what guides them? it may be the heredity of habit that directs the migrants in the long perilous journey. 


\section{The Migration of Birds}

It matters little whether we agree or disagree concerning the various points of bird migration. It is so largely speculative that most of us would rather leave it to the theorist, and take to the fields at the near approach of the robin and bluebird, to greet the early comers as old friends.

In the latitude of East Orange, N. J., about March first, we expect to see the robin, the bluebird, and the purple grackle; by the twentieth we should add to our list the red-winged blackbird, the cowbird, the woodcock, the phœbe, the meadow-lark; and by the end of the month there will probably be field and swamp sparrows, Wilson's snipe, and the purple finch.

From April first we must be astir early, if we expect to keep up with the tide of migration. The sparrow family is rapidly increasing, and a little later there will be the ruby-crowned kinglet, hermit thrush, and barn swallows. Toward the latter part of the month the new arrivals will be the spotted sandpiper, whippoor-will, green heron, towhee, purple martin, swift, green warbler, oven-bird, house wren, thrasher, catbird, and wood thrush. Bird music is heard on all sides, and the most casual observer will notice the new order of things afield. The bird student is now enthusiastic, and all spare time should be devoted to field observations and to the making of careful notes. 


\section{84 The Migration of Birds}

Every moment is precious, for the migration wave will probably reach its height between May third and fourteenth. The hedges and small groves are thronged with migrants. Their plumage is spotless, and in most species the males are easily recognized by their bright colors. This is the time to add new names to your bird list, for upon their return, although upon the whole they move more leisurely, there will be the young, and many of the old birds will have changed color by moulting, thus making identification more difficult.

By May fifth we should have the night hawk, king bird, great crested flycatcher, wood pewee, orchard and Baltimore orioles, indigo bunting, ruby-throated humming bird, scarlet tanager, white-eyed vireo, longbilled marsh wren, Wilson's thrush, chat, and our remaining warblers. By the end of the first week in June we have the birds that intend to remain with us during the nesting season.

One of the earliest nesting birds is the great horned owl. This nest is sometimes found by the latter part of February. The early migrants, that remain with us, begin to nest in the latter part of March or the first of April.

It seems as though we hardly get used to the birds being with us before some of them are preparing to 


\section{The Migration of Birds}

leave; by July twentieth the bobolinks are collecting into small flocks, while a few days later the red-winged blackbirds are gathering in considerable numbers among the tall reeds along the larger water courses. These are the first signs of the fall migration. During August, bird life, considered as a whole, is at low ebb. Some species are slowly collecting, others are roving about as families. There is very little singing; although the indigo bunting and the red-cyed vireo are still tuneful, and occasionally a sparrow is heard by the roadside.

Early in September there is a marked change; the warblers are passing in considerable numbers, and about the twentieth we are overwhelmed by their thousands. We must now begin to look for our winter residents, such as the junco and the winter wren. The summer residents are fast going, and through October and November and into December the various sparrows remain, but finally they, too, retreat before the increasing cold and snow.

The manner of migration is a study in itself. Whether we decide that birds find their way by instinct or by heredity of habit, we marvel at it none the less. It is wonderful that birds can travel such great distances over mountain, forest, and plain-and even for a considerable distance over the sea-and 
then, at the appointed time in the spring, return to us across all this vast space.

Some of these birds fly by night, others by day, and some by both day and night. This was first established by Mr. William Brewster, who writes as follows:

"Timid, sedentary, or feeble-winged birds migrate by night, because they are either afraid to venture on long, exposed journeys by daylight, or unable to continue these journeys day after day without losing much time in stopping to search for food. By taking the night for travelling they can devote the days entirely to feeding and resting in their favorite haunts. Good examples are the Thrushes (except the Robin), Wrens, Warblers, and Vireos.

"Bold, restless, strong-winged birds migrate chiefly, or very freely, by day, because, being accustomed to seek their food in open situations, they are indifferent to concealment, and being further able to accomplish long distances rapidly and with slight fatigue, they can ordinarily spare sufficient time by the way for brief stops in places where food is abundant and easily obtained. Under certain conditions, however, as when crossing large bodies of water or regions scantily supplied with food, they are sometimes obliged to travel partly, or perhaps exclusively, by 


\section{The Migration of Birds}

night. Excellent examples are the Robin, Horned Lark, and most Icteridæ (Bobolink, Blackbird, and Orioles).

"Birds of easy, tireless wing, which habitually feed in the air or over very extensive areas, migrate exclusively by day, because, being able either to obtain their usual supply of food as they fly, or to accomplish the longest journeys so rapidly that they do not require to feed on the way, they are under no necessity of changing their usual habits. The best examples are Swallows, Swifts, and Hawks."

Storms or foggy weather interfere seriously with the flight of birds,-this being particularly true of the night-flying varieties. There are natural highways along which birds travel, such as the coast line, mountain ranges, or river valleys, and on clear nights these are probably discernible, while under unfavorable conditions progress is slow and doubtless many lose their way. Unless one has carefully observed, it does not seem possible that birds travel in such vast numbers at night. Their flight through the darkness during migration may be compared to the flight of pigeons, so common in this section of the United States fifty years ago. The telescope has greatly aided in ascertaining this, as well as in revealing the fact that birds fly at a very great height, some species 
probably a mile or more. A telescope with a threeinch objective will serve every purpose, and a still, clear night with a full moon is necessary for good results. Focus the instrument upon the moon, the birds, as they pass, appearing quite distinctly against the reflecting planet. With a larger telescope it is possible to detect the species that have well marked and not too rapid wing beats. With a six-inch glass, under favorable conditions, as many as two hundred and eighty birds have been seen within three hours.

I have observed the night flight of birds several times from the tower of the East Orange High School. Even an arc light with a good reflector is sufficient to attract the birds under favorable conditions, but with a searchlight good results were obtained. These night watchings have always proved most interesting to me and to friends who have been with me at various times, but one of the most interesting evenings I ever spent in the tower was on September 23, I890. The weather conditions were perfect. Shortly after eight o'clock the first bird was seen, although others had been heard almost constantly. In the next half-hour two more birds were seen, but their call notes greatly increased as they hurried past us. The night was only partially clear, and as it advanced a threatening thunderstorm came up at 


\section{The Migration of Birds}

about half-past ten. Almost as quickly, there was a decided increase in the number of call notes, and dozens of birds came within the range of the light, and several hovered about it, reminding one of large moths before a flower. When the rain finally ceased and the stars came out, the birds quickly ascended into the higher regions. Toward morning there seemed to be but a few stragglers, and before the sun rose the wave had passed.

Frequently lighthouses are so situated that they afford excellent points for observation. Many times birds fly against them and are injured or killed during their night flights. It has been my experience to find more frequently the yellow- or black-billed cuckoo and vireos than other species killed by flying against the tower. This would lead me to believe that they do not fly so high as the others, or that they cannot see so well to avoid objects. This observation has extended over a period including twenty-four migrations.

The speed at which birds migrate is a subject beset by many difficulties. There are several things to be taken into consideration; such as, whether it is the spring or fall migration, the first or the last part of it, the climatic conditions, and the accessibility of food. The average speed per day can be gotten at 


\section{90 The Migration of Birds}

very much more readily than the actual speed on any particular day. For example, the barn swallow arrives at Greencove, Florida, March fifteenth, and forty days later arrives at New Berlin, N. Y., eight hundred and seventy miles north. This is an average flight of about twenty-one miles per day, but when we take into consideration time for rest, storms, and other hindrances, the actual distance covered on some days must have been considerably greater. This, however, does not test the flight of the swallow when considered for a short time. Experiments have been made in which swallows attained a speed of one hundred and six miles per hour.

In our migrations the average speed of fifty or sixty species per day is a little less than twenty-five miles. The wild goose in migrating northward covers a distance of from three hundred to six hundred miles in a single flight, the American golden plover exceeding even this by a thousand miles.

We have now considered the various phases of bird migration in spring and fall, and noted that the last to come were the first to go, and that the earlier birds remained the longer. Must we drop our delightful out-of-door bird study for the next three months-December, January, February? By no means. Of course for many of our lady bird-lovers 


\section{The Migration of Birds}

and some others, the undertaking seems too great for the supposed meagre returns, but short skirts and properly dressed feet go far toward making a tramp through the fields and woods, even during the winter months, wonderfully delightful. Speaking generally, the most common bird will now have an unusual amount of uncommon interest about it. It will be almost as good as the study of a new species-in some ways it is better. The delightful tramp through the bracing air, and the fact that you have seen an old friend under new conditions, will make you rejoice more than will the sight of a dozen birds when birds are plentiful.

During the winter months the birds are not so scarce, only we must know where and how to look for them. We have with us our permanent residents, which include most of the hawks and owls, bluejay, bob-white, song sparrow, crow, meadow lark, flicker, American goldfinch, ruffed grouse, purple finch, and a few others. These with our winter residents, the brown creeper, junco, crossbill, white-throated sparrow, snowflake, northern shrike, and redpoll, still leave us a considerable variety for study. A thorough acquaintance with these winter birds alone will take us many a season.

These are but a few of the many facts concerning 
192 The Migration of Birds

bird migration. As you study the subject from year to year, and carefully compare your notes, you will find the movement a very constant and regular one, and, as time goes on, your interest in it will increase rather than diminish, and you will find yourself wondering why it is that each spring you greet the bluebird and the oriole wi.h a little deeper feeling. 


\section{THE BLUEBIRD}

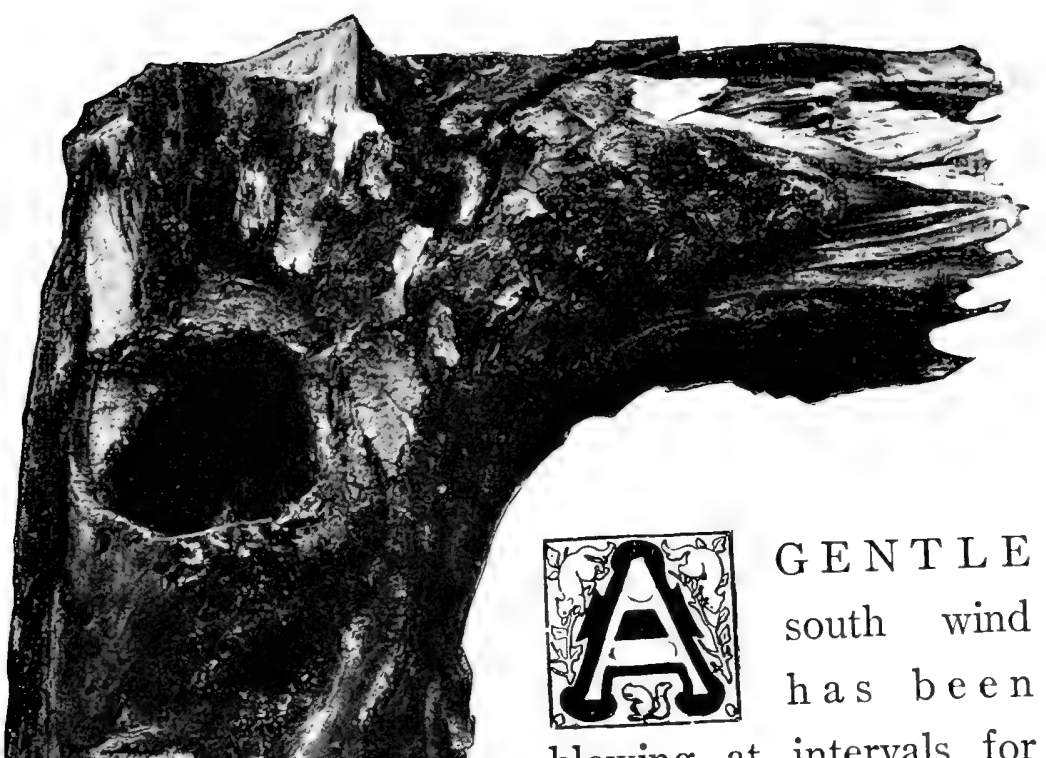

blowing at intervals for a week, the snow banks are diminishing in size, and here and there the brown earth seems to be pushing itself up from beneath the drifts. The sun has loosed the icefetters, and again the murmur of the brook is heard; while over the water the pussy willows are hanging their swollen buds, and out in the grove 


\section{The Bluebird}

the sap is beginning to drop from the maple trees. These are indeed signs of spring! Now it is time to listen for the note of the bluebird. A plaintive note it is at first, but it will soon give place to a pleasing song, never loud, but always sweet and altogether suggestive of the warblers.

How welcome it is, - that bit of blue and brown, flitting among the yet naked boughs of the old apple trees! We look for the bluebird in spring with a feeling different from that for any other bird during the whole year. His note awakens within us the assurance of the quick return of the spring beauty, and wake robin, and a whole troop of songsters.

In a day or two Lady Bluebird will arrive, a very modest little woman, with less brightly colored plumage, and more retiring manners, than her lord's. Now, if you are patient, you will have an opportunity to observe a most interesting courtship; for Mr. Bluebird is an attentive lover, exhibiting to his lady all the charms of his beautiful plumage, singing to her his sweetest songs, and feeding her with the choicest bits of food to be found. In actual bird life it sometimes happens that a rival appears upon the scene, and then many are the contests with voice and beak, until one or the other is vanquished. After this the courtship proceeds smoothly, and before long 
the birds begin to look about for a suitable place for housekeeping.

The "bird-boxes" and small cavities in trees are carefully inspected, until a spot is found to their

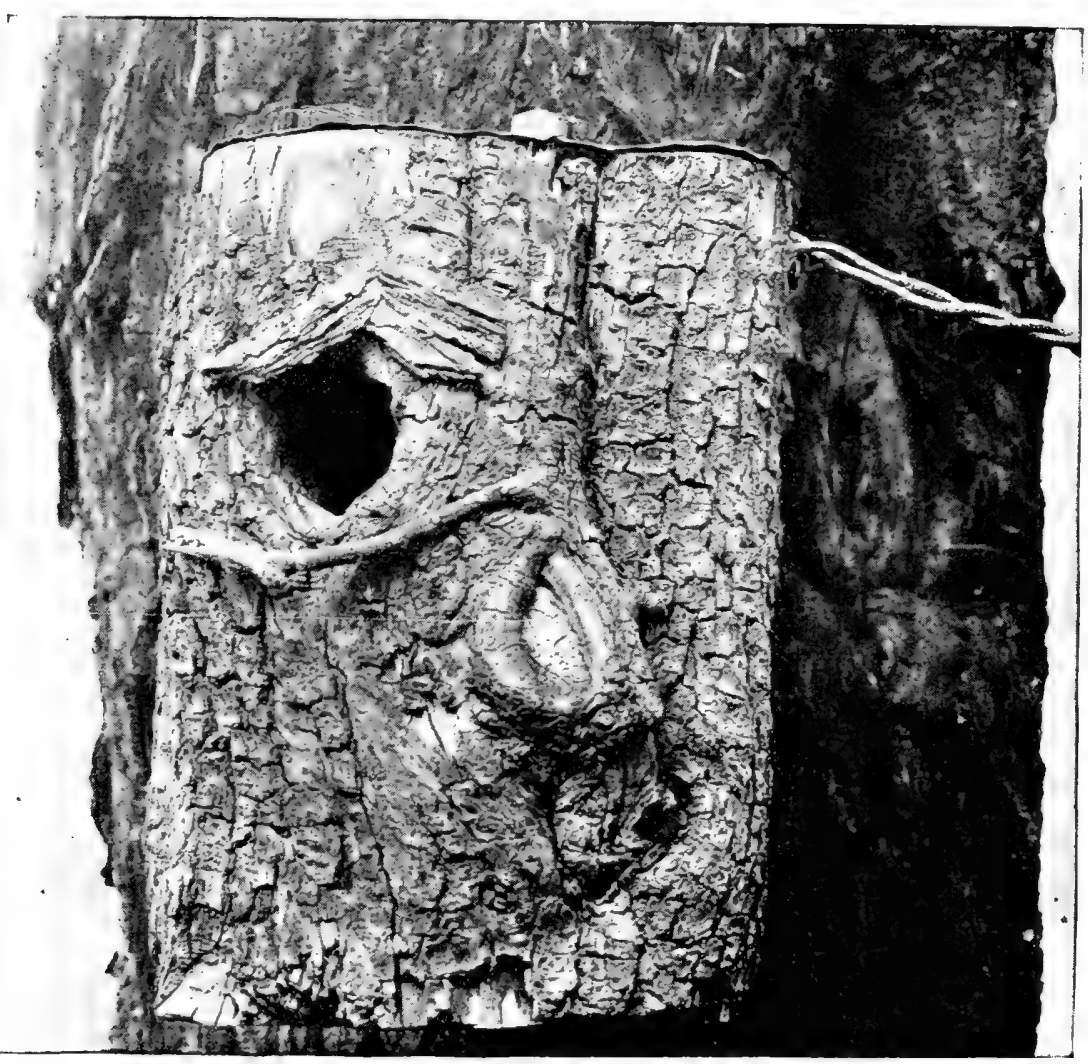

The "Bluebird Box"

liking. If the birds are not interfered with, the work of nest building progresses rapidly. But when the bluebirds are once settled they are very determined, usually succeeding in maintaining their own against 


\section{I96 The Bluebird}

their enemies, of which the house wrens, and especially the English sparrows, are chief. However, owing to the continuous warfare waged against them by these pugnacious foes, the bluebirds are, year by year, becoming less numerous about our dwellings.

In my bird note book I find a sketch of the bluebird families that have, for several years in succession, occupied my "bird-box." This artificial home consisted of a hollow limb, about twenty inches long and eight in diameter, closed at top and bottom, and having an entrance for the birds on one side, while on another side was a door, through which the nest and its contents could be inspected. In the wall opposite to the bird's entrance a microphone was arranged, and a line joined it to a telephone receiver in the house. This unique "bird-box" was located about twelve feet above the ground and made fast to the body of a tree that stood in the rear of the house.

I did not expect to obtain results that could any more be turned into words than could the music of the veery or the murmuring of a mountain stream; but I wanted to hear the notes of the old birds and young, when undisturbed by man, and this was the only method known to me of accomplishing the desired end. 
When the arrangements were completed, I waited for the house to be occupied. By March twentieth it had been inspected by many bluebirds, but none had decided to remain. Through the apparatus I had

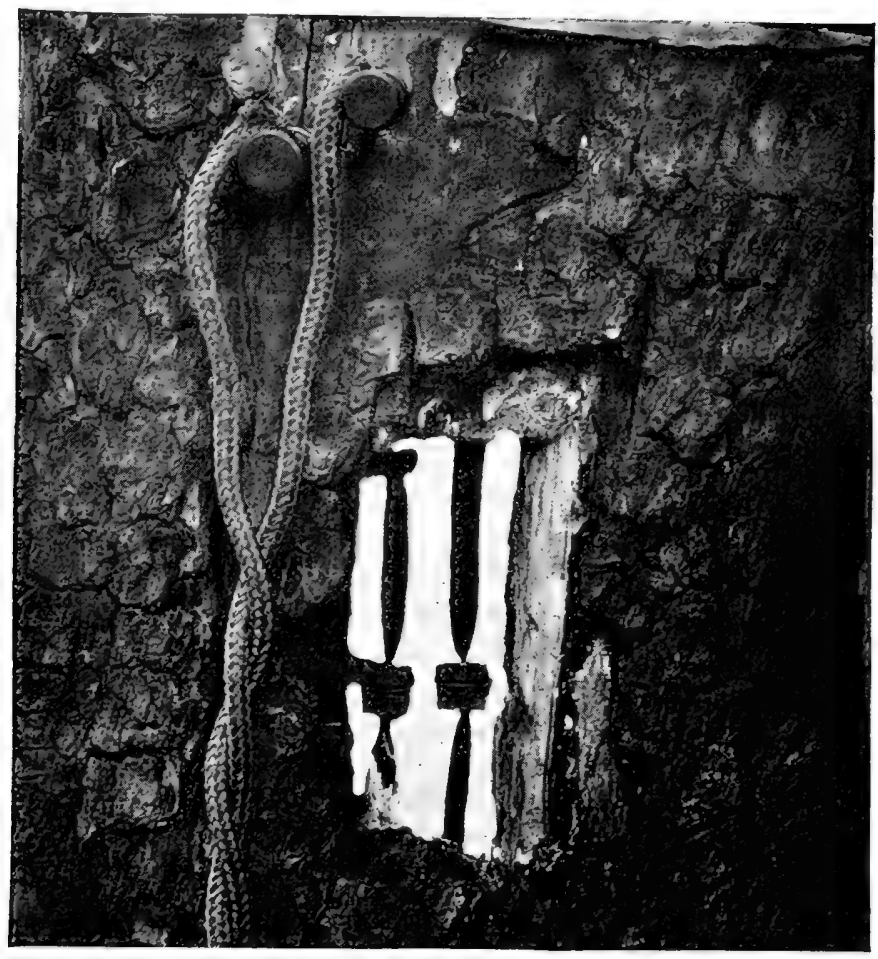

Section Removed Showing Microphone

the pleasure of listening to bluebird conversations such as I had never heard before. As the birds were house hunting their notes were at times very spirited, and their quick movements were plainly indicative of excitement. 
The first week in April, after a very careful inspection of the house inside and out, a pair of bluebirds decided to remain. They commenced the nest at once, using fine grass as material, and the sounds of their building could be heard very distinctly through the telephone receiver. The third day a great commotion was heard over the line, and upon investigating I found that some English sparrows were trying to turn the bluebirds out. After two days of disturbance the bluebirds were victorious, but the male bird kept a very careful watch about the box for several days, proving himself to be a veritable "blue streak" to every English sparrow that came within a hundred feet of his home.

In due season the nest was finished, and on April twenty-third there were five eggs. By May seventh all the eggs were hatched. The peeping of the little birds and the quieting notes of the mother could be plainly heard through the receiver. The notes varied greatly in pitch and quality; the mother bird using certain notes that the little ones appeared to answer, just as chickens will respond to certain sounds and movements of the hen. A certain note from the mother hen will call the chickens, while another will send them immediately to cover, if a hawk appears in the sky. 


\section{The Bluebird}

If one carefully approached the tree and scratched on the bark, the mother would give one low note and every noisy baby bluebird would immediately become quiet. Each repetition of the experiment called forth the same low note. This is characteristic of other birds as well. The ruffed grouse does it, and there is every reason to believe that all birds have some sort of a language of their own.

The old birds of this family became very tame. On the ninth day after the young were hatched the female must have been killed, for she disappeared on that day and was not seen again. This tragedy seemed to discourage the male, and as the young were in danger of starving, we took them into the house and brought them up by hand. They became great pets, and after they could fly about the yard they would come for their food several times a day. They remained until August fifteenth, and after that I was not sure that I saw them again, for one bluebird looks very much like another.

In late summer the song of the bluebird is changed to a plaintive note that is as suggestive of coming winter as the song is of returning spring. At this season of the year, and especially in autumn, it is usual to see small flocks of them along the roadsides and about the orchards. At the approach of winter the greater number of these bluebirds migrate to the southern part 


\section{The Bluebird}

of the United States, and some probably go as far south as the West Indies.

During mild winters a few remain in the Northern States, and those who are fortunate enough to ramble about the hedges and byways sometimes find them in sheltered places. On pleasant days, too, the bluebirds may sometimes be scen in the open fields among the brown weeds, eagerly searching for the few seeds that the wind shakes from the pods still standing above the snow; or, perchance, they may be found about the hay stacks near the barns, where the cattle are fed in pleasant weather.

One January morning I saw a very unusual birdpicture about one of these stacks. The ground was covered with a thick blanket of snow, over which the hay had been scattered. The loosened seeds were tempting bits of food for the hungry wild birds, and as the morning grew warmer a flock came from the thick underbrush of the woods near by. The greater number were snowflakes, but there were a few sparrows and five bluebirds. On Nature's white background the blue of the bluebirds, the gray of the sparrows, and the brown and white of the snowflakes made indeed a variety of color and contrast.

The sweet disposition and gentle, lovable ways of the bluebird are evident even in captivity. I once had 

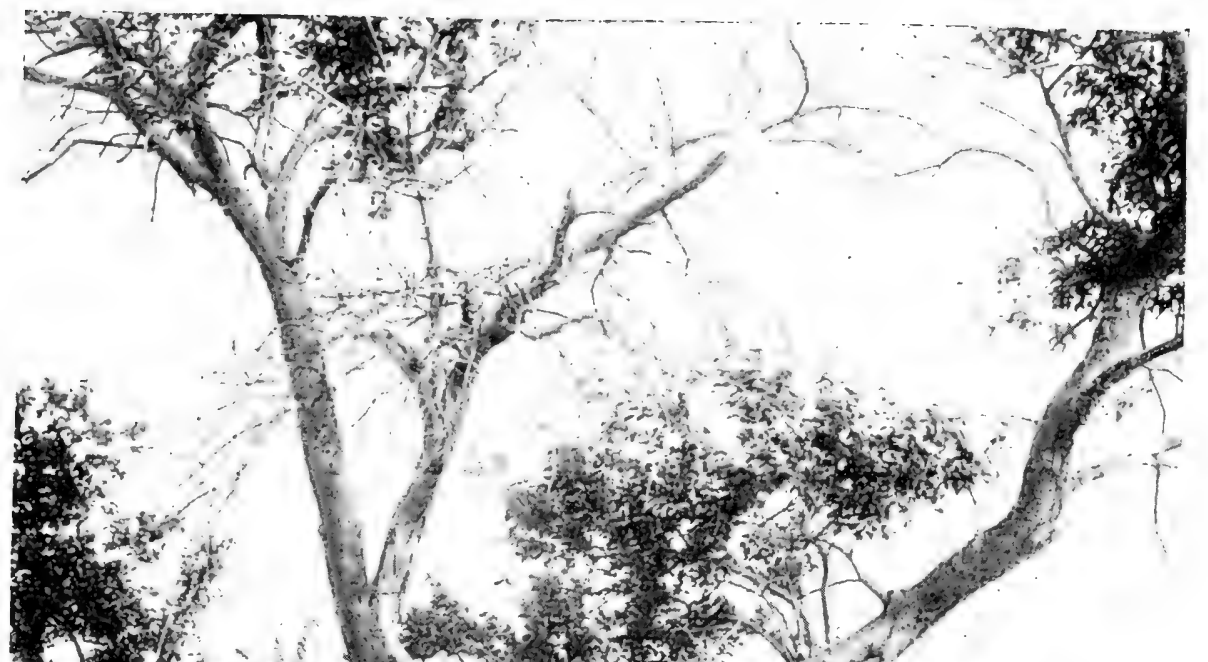

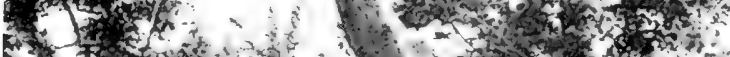

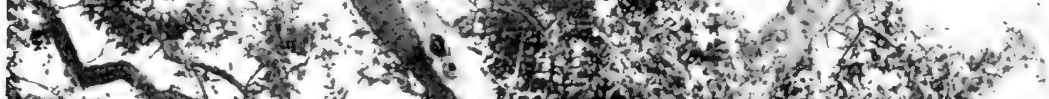

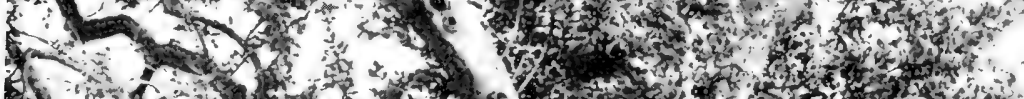

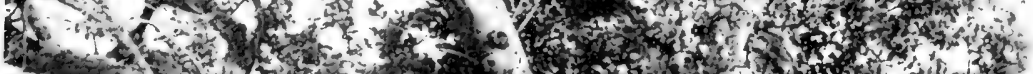

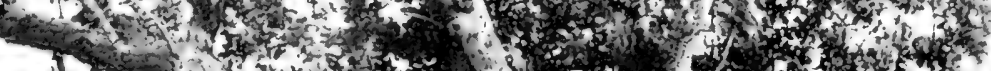

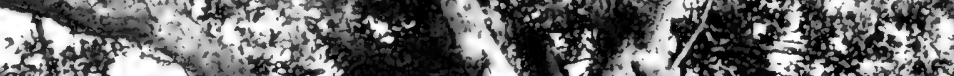

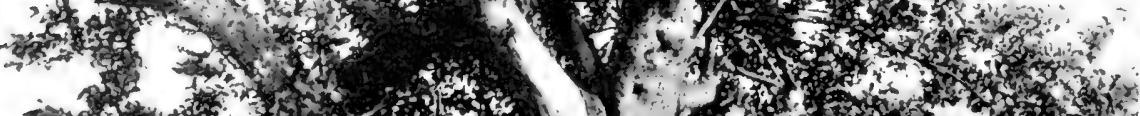

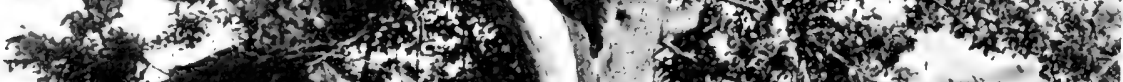
For

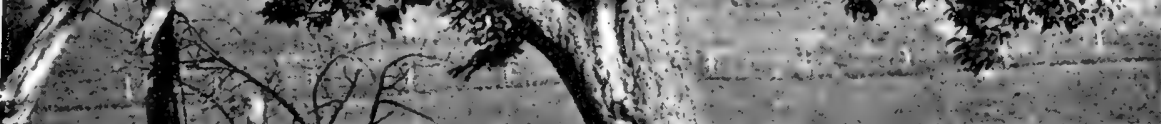
E. $+\frac{1}{2}$

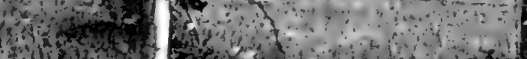

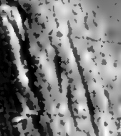

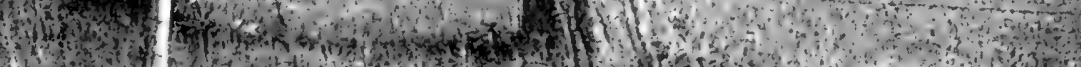

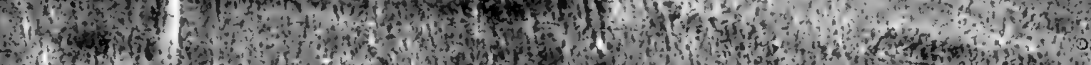

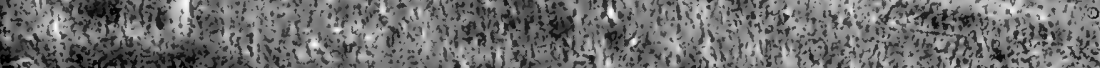

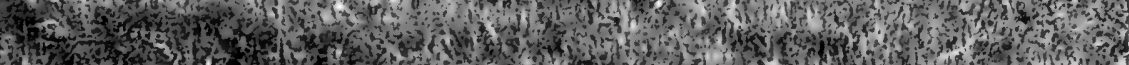

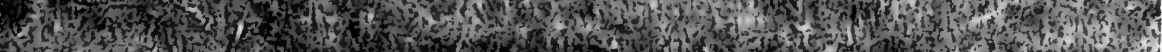
5 m.

The Bluebird Tree 
-... 


\section{The Bluebird}

the pleasure of carefully studying the habits in captivity of both old and young of this species. The old birds were kept in a large room with several other varieties of American birds, and here they were models of good behaviour, not only among their own kind, but in their relations with the other birds.

The young birds were kept in cages, and with a moderate amount of care and attention became very tame. It was amusing to see them, about the usual feeding time, arrange themselves on a particular perch. Each bird, in order of precedence, would take the food from a stick, and if one was purposely omitted, there was no fluttering of wings or selfish attempt to obtain the morsel as it was offered to the next bird.

These unselfish table manners I have observed in wild bluebirds as well. Several years ago a pair of bluebirds selected, as a home, the deserted winter quarters of a downy woodpecker. The cavity was located in the dead branch of a cherry tree which stood in the yard in the rear of the house. On the seventh day after the young were hatched, a severe wind and rain storm so broke and split the old stub that the young were in danger of perishing. We soon converted a small basket into a temporary and comfortable nest for the unfortunate family, and from a second story window of the house we watched the birds unobserved. 


\section{4}

\section{The Bluebird}

The old birds accepted the situation, and continued to feed and care for the young. As the food was brought there was no strife on the part of the young birds, but each waited his turn. This continued not only while the young were in the nest, but until they flew away.

The bluebird makes a very playful and affectionate little pet. Mr. A. Radclyffe Dugmore tells of a very interesting one he possessed. "While I am writing," he says, "a pet one, but three months old, is sitting on my paper, seeming to wonder what I am doing and why I do not play with him. He nips my pencil, but I pay no attention to him; then he tries to creep up my sleeve, and still I pay no attention; so, disgusted, he flies off in search for ants or other small insects. After a time I raise my hand and call; back he comes, like a flash, and, hovering more like a large moth than a bird, he perches on my finger, singing at the same time a soft little song that is his method of speech." 


\section{THE ROBIN}
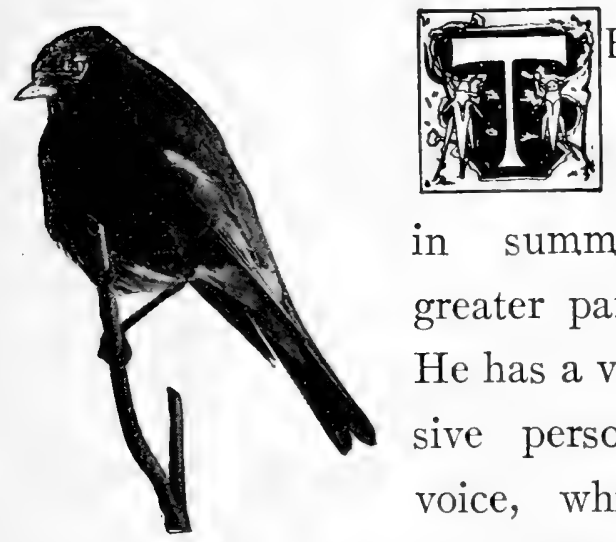

HAT familiar and much-beloved bird, the robin, is found in summer throughout the greater part of North America. He has a very strong and aggressive personality, and a clear voice, which always plays a prominent part in our morning bird chorus. His cheery friendliness renders him a great favorite, and his song compares very favorably with that of other members of his family. Although his music does not equal that of the thrush-that sweet warbler of the glen-there is scarcely another bird which expresses so much in its tones as does our robin.

A few robins remain during the winter in the Northern Sates, but most of them migrate at the approach of cold weather. In the Southern States during the winter months the robins may be found in enormous 
flocks feeding upon the holly, mistletoe, and Virginia juniper. There is very little singing at this period, but the call notes are frequently heard.

Robins migrate for the most part in flocks, arriving in considerable numbers in the latitude of New York about the middle of March. At this time they are in full song, although a few days later their music is more spontaneous and joyous. We are accustomed to date the real beginning of spring, not by the day of the calendar, but by the arrival of the robins. As we hear the old familiar song, we stop to listen, and pronounce it a splendid performance.

You hear a great deal about the damage done by the robins in the cherry trees and berry patches. Why shouldn't the robin come in for his share? He has labored several months of the year in order that the trees might produce, therefore a part belongs to him. It has been said by Dr. Coues: "The robin is a great eater of berries and soft fruits of every description, and these furnish, during the colder portion of the year, its chief sustenance. Some of the cultivated fruits of the orchard and garden are specially attractive, and no doubt the birds demand their tithe; but the damage in this way is trifling at most, and wholly inconsiderable in comparison with the great benefit resulting from the destruction of 


\section{The Robin}

noxious insects by this bird. The prejudice which some persons entertain against the robin is unreasonable; the wholesale slaughter of the birds which annually takes place in many localities is as senseless as it is cruel. Few persons have any adequate idea of the enormous, the literally incalculable, number of insects that robins eat every year. It has been found, by careful and accurate observations, that a young robin, in the nest, requires a daily supply of animal food equivalent to considerably more than its own weight. When we remember that some millions of pairs of robins raise four or six young ones once, twice, or even three times a year, it will be seen that the resulting destruction in insects is, as I have said, incalculable. I have no doubt that the services of these birds, during the time they are engaged in rearing their young alone, would entitle them to protection were the parents themselves to feed exclusively upon garden fruit for the whole period. But at this time the diet of the old birds is very largely of an animal nature; nor is this the only season during which the destruction of insects goes on. Upon the first arrival of the main body of birds, early in spring, long before any fruits are ripe, they throw themselves into the newly ploughed fields, and scatter over meadows, lawns, and parks, in eager search for the 
worms and grubs that, later in the season, would prove invincible to the agriculturist, were not their ravages thus stayed in advance by the friendly army of robins."

During the breeding season robins nest about the garden and house, sometimes even on the vines grow-

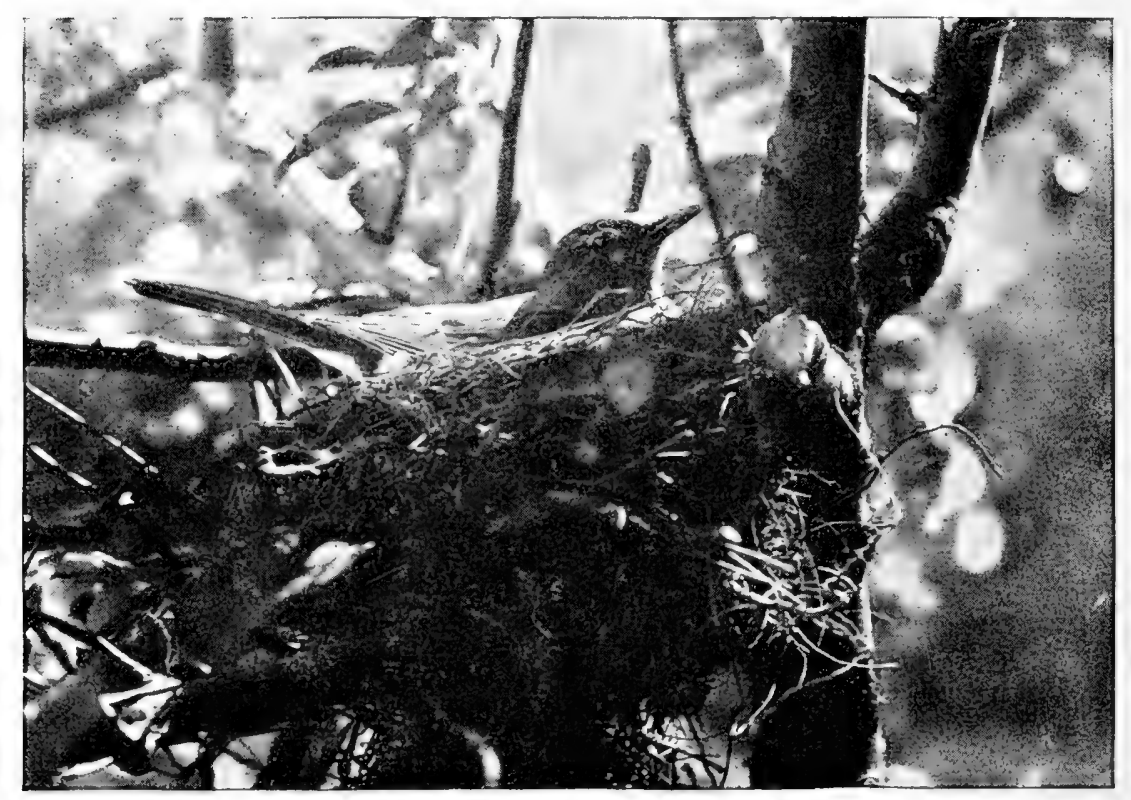

Robin on HER Nest

ing over the veranda. Th favorite place of nesting seems to be about old and neglected orchards, but never have I found a nest in the deep woods. The robin when not molested has little fear of man, and the building of the nest and rearing of the young can be very carefully observed by any one. For 


\section{The Robin}

this reason this is one of the best of birds for the young ornithologist to begin to observe.

A few years ago I interested one of my young boy friends, who for two years past had been inclined to rob birds' nests, by making with him a careful and systematic study of the robin.

On April twelfth a pair of these birds was discovered building a nest in a lilac bush close to the house, and but a few feet from the dining room window. The nest had scarcely been begun when discovered, and I determined, for the sake of my young friend, to cultivate friendly relations between ourselves and the robins.

The female was a half albino, the wings being partly white, and she had a few white feathers on her breast. The male was so much like other robins that, only as he grew tame, could we distinguish him. As it has been found that most animals are made more approachable by satisfying the appetite for food-even man being no exception-we decided to take advantage of this fact. Accordingly, on April fourteenth we placed a small board in the fork of two limbs of the lilac bush, on which we intended to offer food to the robins. We made it our business to be about the lilac bush and at the window as often as convenient, at first without ap- 
parently noticing the birds. In the beginning they were quite easily disturbed by our presence, and also by the appearance of the board so near their nest; the fear soon passed away, however, and it was surprising to notice how quickly it was dispelled after we began feeding them. In two days the robins would take food from the board while we were at the window, only six feet away.

Meanwhile the building of the nest was progressing, and as it was only ten feet from the widow, the process of construction could easily be watched. Both birds took part in the building, although the female seemed to do the most of the work, particularly the shaping of the nest, which was done largely by means of her body. The nest was finished on April twenty-fifth, and it was a typical robin's nest; the bulky part being composed of roots and grasses, while the inner wall of mud was lined with very fine grass and a few long horse hairs.

On April twenty-sixth the first egg was laid. On the second day following, another, and so on, until the nest contained four eggs. The eggs were deposited in the morning between the hours of eight and twelve, and were of a beautiful greenish blue color, characteristic of the family to which the robin belongs. The female was on the nest but little until April thirtieth, 


\section{The Robin}

but on May second the serious business of incubation began. In this the female took the most active part, being relieved about an hour and a half each day by the male, and with one exception she covered the eggs at night, although there was no apparent reason why the male should have assumed the responsibility on this particular night. Sometimes the male brought food to the female while she was on the nest.

On the eleventh day after incubation began, the first young robin appeared, and two days later the other three eggs were hatched. The young birds grew very rapidly, and in twelve days were ready to leave the nest. During the time the young were in the nest the old birds constantly took food from the board, particularly worms. The young robins were quite tame at first, but, as time went on, gradually grew wilder, and finally disappeared altogether on June fifteenth. We often saw the female about the house, and the first week in July the old nest was used again for a second brood, which was reared without accident.

There being no distinguishing marks on the male, he was lost sight of on August twentieth. The female was last seen on September twenty-sixth. The disappearance of the old birds ended the observations for the year. The results had been successful beyond 


\section{I 2 \\ The Robin}

my expectations. I hoped to carry the study farther the next scason, and assist my young friend in answering the question which is so hard to answer, "Do

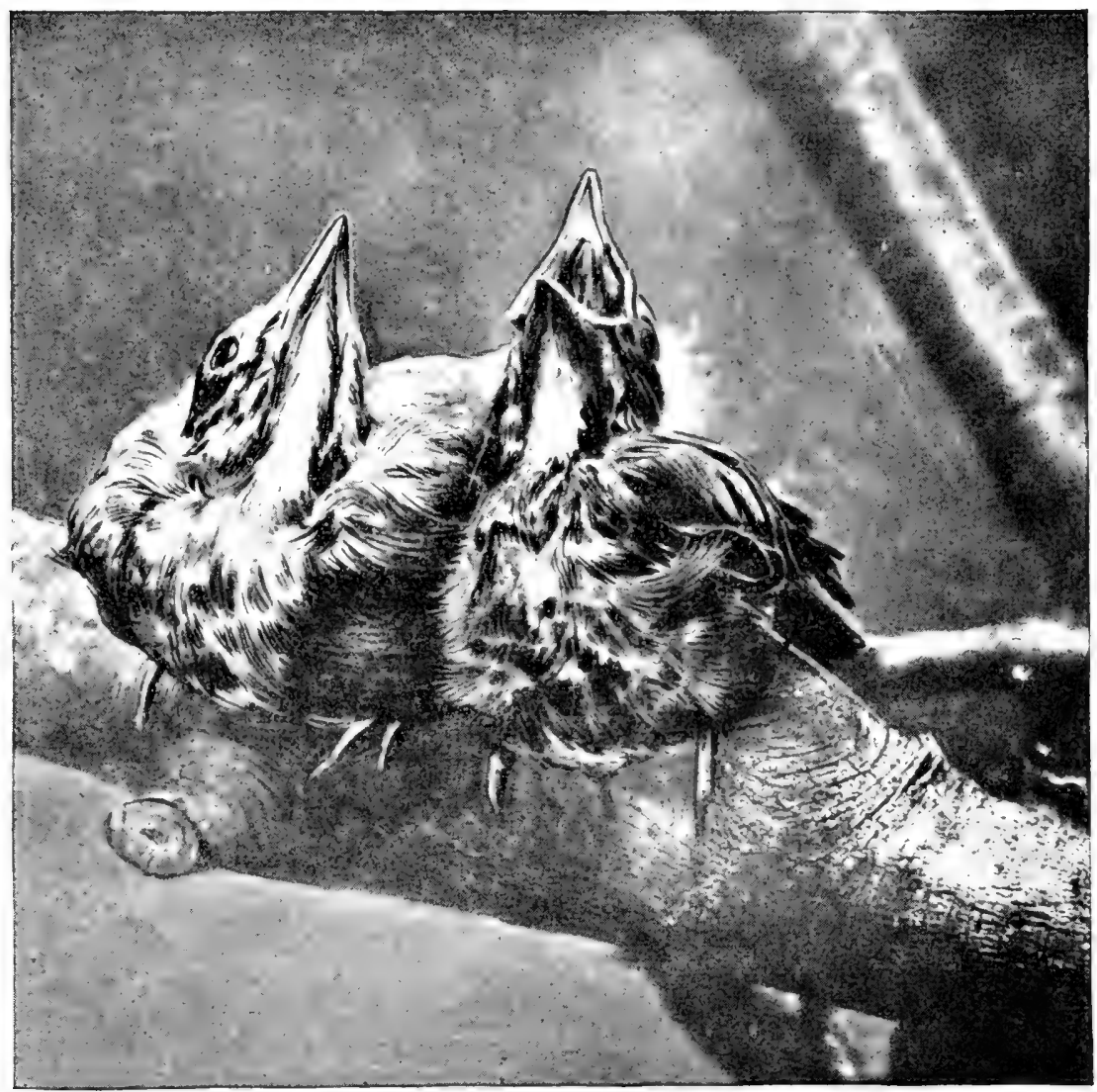

Young Robins Thirteen Days Old

birds return to the same nesting place year after year, and do they remember their human friends?"

The most direct benefit of the study, aside from the knowledge gained, was the conversion of the 


\section{The Robin}

boy egg-collector into a protector of birds; and strange as it may seem, his first real interest came with the keeping of notes.

During the following winter the old nest was blown from the lilac bush. When March came, we kept a careful watch for the robins, and by the fifteenth several had been seen. On March twentieth one of our old friends appeared. It was the female, unmistakable because of her peculiar markings. She seemed as tame as when she left on her fall migration. For a week she remained about the lawn and old orchard, and then disappeared for a few days, but on April sixth returned with her mate and began a nest in a bush close by the house. Only one brood was reared this season. The following spring she returned and reared two broods. With her fall migration our acquaintance ended. The next spring we waited and watched, even placing food upon the board in the lilac bush, but our old friends did not appear.

\section{WHY THE ROBIN'S BREAST IS RED.}

According to a certain legend, a bird played a part in the crucifixion. It was a modest little bird with gray plumage, which approached the cross timidly, uttering cries of grief. With its wings it tried to wipe away the blinding sweat and blood from the face of 


\section{The Robin}

Jesus, while with its beak it tried to pluck away one of the thorns which was piercing his forehead. A single drop of blood fell on the breast of the pitying gray bird, and gave to the world the Robin Redbreast. Jesus said: "Blessed be thou, little bird, which sharest my sorrows! May joy accompany thee everywhere! Thine eggs shall be blue as the sky above; thou shalt be the 'bird of God,' bearer of good tidings." 


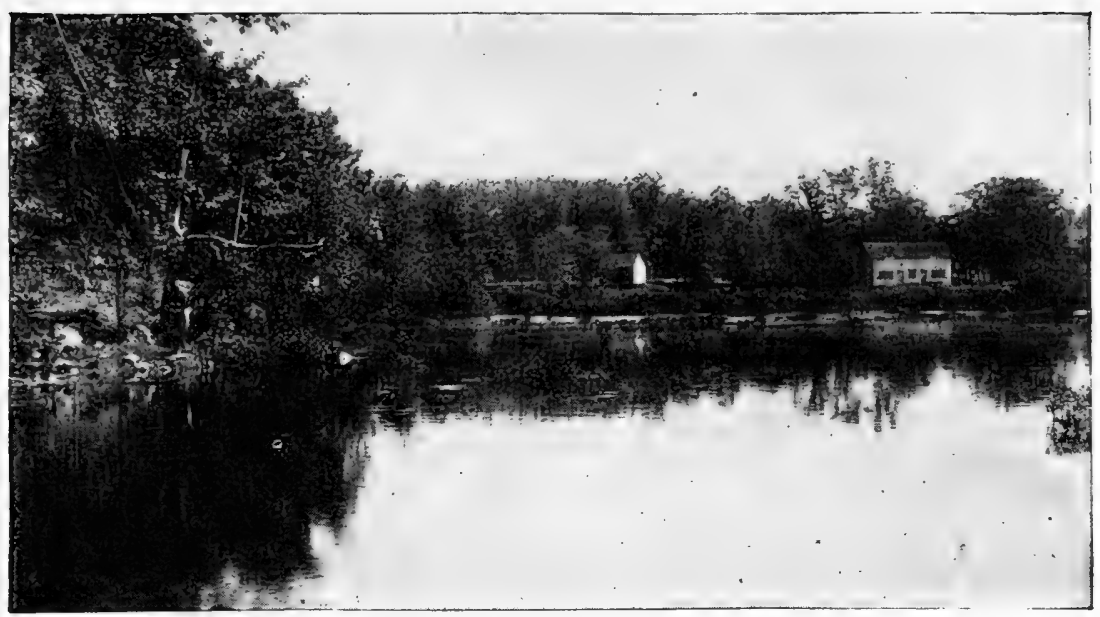

The Feeding-ground of the Chimney Swift

\section{THE CHIMNEY SWIFT}

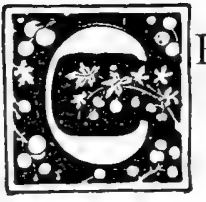

HIMNEY SWIFTS are found in all parts of the globe except the colder portions. There are about seventy-five known species, but of these only four live in North America. The swifts have slim bodies, rather short and compact feathers, while, for such small birds, their wings are unusually long and powerful, giving them unrivalled powers of flight. The natural homes and retreats of the swifts were formerly in hollow trees and caves, but these have been gradually abandoned for the chimneys used by civilized man. This adoption of a new home is a marked illustration of the readiness with which a bird may change its nesting place. Whether the home of the swifts is natural or artificial, when nesting 
they are always associated in scattered companies, but for a few weeks before the fall migration they are decidedly gregarious, roosting in great numbers in favorable localities.

One species of the swift family, which breeds in various parts of the Malay Archipelago, is famous for making an edible nest. It was thought for a long time that the substance, used by the birds in the manufacture of these nests, was chiefly seaweed, partly digested and mixed with mucus from the salivary glands, but from recent chemical analysis it has been proved beyond doubt that it is mucus alone. There are some famous swift caves in the northern part of Borneo, and I quote the following from Mr. H. Pryer, who visited these caves some time ago:

"At the White Cave and others I saw the nestgatherers at work getting in their crop. A thin rattan ladder was fixed to the end of a long pole and wedged against the rocks. Two men were on the ladder; one carried a long four-pronged spear, a lighted candle being fixed to it a few inches below the prongs. By the aid of this light a suitable nest is found, and transfixed with the prongs; a slight twist detaches the nest unbroken from the wall of the rock. The spear is then passed within reach of the second man, who takes the nest off the prongs and places it in a pouch carried at 


\section{The Chimney Swift}

the waist. The nests of best quality are bound up into packets with strips of rattan, the inferior being simply threaded together; the best packets generally weigh about one and a third pounds, averaging forty nests, and are sold at nine dollars each. These caves have been worked for seven generations without any diminution in the quantity; three crops are taken during the year."

Our chimney swift is a migratory bird, arriving from Central America, or still farther south, about the middle of April, and remaining until late in September. This bird is usually called a "swallow," or perhaps more frequently a "chimney swallow," but the likeness exists only in its habits and mode of dress, and not in its structure. Even in dress they may be easily distinguished, for the swifts have ten primaries, or long wing-feathers, and an equal number of tail feathers, the shafts of which are exposed at the end, thus aiding the bird in clinging to an upright support; while the swallows have nine primaries and twelve tail feathers. As a matter of fact the swifts are more nearly related structurally to the goatsuckers and humming birds than they are to the swallows.

Not only is the chimney swift confused with the swallow, but it shares some of the uncanniness ascribed to our bats, snakes, and toads. This is probably due 
to the nocturnal habits of the swifts and also to popular fables, written fifty years ago, concerning certain birds whose habits were at that time little known. It was, for a long time, believed that in the autumn swifts collected by hundreds in hollow trees, together with bats, snakes, and toads, and that at the appointed time all fell into a deep sleep, lasting until spring was well advanced. Others went still farther beyond the bounds of reason in declaring that the swifts descended to the bottom of rivers, ponds, and lakes, where, during cold weather, they buried themselves in the mud with the catfish, the eels, and the snapping turtles. It is surprising how long such fairy tales cling to a species, for less than a year ago an old lady told me, that when she was a girl the "chimney swallows" from all the surrounding country collected at her father's mill pond, and then at night, when no one knew it, "they dove to the bottom of the pond and remained there until the cowslips came up."

Our chimney swift, in common with the other species of the family, has remarkable powers of flight, the estimated speed being from eighty to one hundred and ten miles an hour. This wonderful speed is attained by only a few of our birds. The swift is more often seen flying in the morning or late afternoon, and it apparently enjoys wet and gloomy 


\section{The Chimney Swift}

weather more than the sunshine. The swift, like the swallow, feeds on the wing and its movements are swift and graceful, as it flies to and fro over its favorite feeding grounds. At times the wings vibrate very rapidly; then again the movement is but slight, producing a series of glides through the air, beautiful to see. During this splendid exhibition of flight there occurs at short intervals the not altogether unmusical sharp and rolling twitter.

The nest of our swift is one of the most remarkable structures to be found among our common birds. It is usually placed in a chimney and is composed of twigs quite uniform in length and size, woven into a semicircular basket. As they seldom frequent the ground, there has been considerable speculation concerning the methods by which the swifts obtain their nesting material. It has, however, been found that instead of selecting material already scattered about by the wind they break twigs from dead limbs or trees, while in full flight. These twigs are held in place upon the side of the chimney and where they cross each other, by a very adhesive saliva secreted by the birds. When the nest is completed it is quite shallow as compared with that of a robin, being usually not more than a fourth as deep, and having none of the soft lining usually found in the nests of 
other birds. On the contrary, the home of the swift is rather rough within, while the entire surface, inside and out, has a glistening appearance due to the abundance of saliva which is used, not only at the

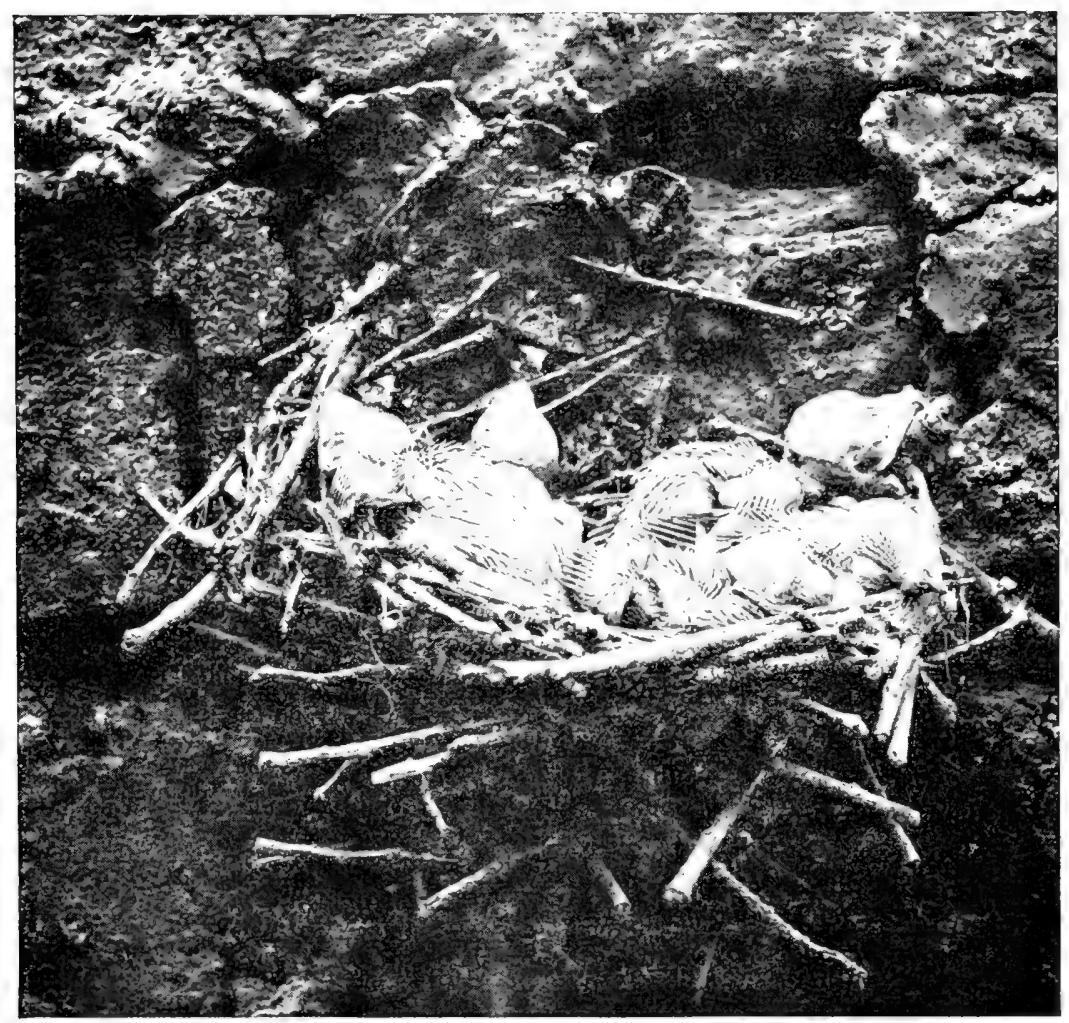

Nest and Young of the Chimney Swift

intersection of the twigs, but also scattered somewhat promiscuously over them. The saliva when dry is a hard gluc-like substance, possessing considerable strength, but when moistened by continued rains it 


\section{The Chimney Swift}

gradually softens and then it not infrequently happens that the nest, weighed down by the young birds, falls to the bottom of the chimney. If the fall does not kill the nestlings, they usually climb up the sides of the chimney for a short distance, and here they remain in a hanging position, being fed by the old birds until they are ready to fly and shift for themselves.

The young swifts are very interesting, although somewhat uncanny in their actions, resembling in their constant movements a bunch of wriggling snakes. At first I thought they were irritated by the vermin, so common about birds' nests, but as I failed to find anything of the sort, I looked for another cause. After careful observation I concluded that the movements were due to an innate desire on the part of the young birds to preen their feathers, although the feathers had scarcely started. One does not become thoroughly aware of the constant motion of the young birds until one attempts to "take their picture," when their restlessness becomes painfully apparent; it being almost impossible to catch the whole brood motionless, even for the fraction of a second. For this reason, in addition to the fact that their surroundings are such that the light is poor at the best, they are most difficult young birds to photograph. 
The swifts feed their young during the greater part of the night, and the noise made by their wings while passing in and out of the chimney often resembles the low rumbling of distant thunder. This is more pronounced by the time the second brood is reared, but it becomes unbearable only when, as sometimes happens for a week or two, a few hundred swifts take up a temporary residence in an old fashioned chimney, before starting on their southern journey.

I remember very distinctly flocks of this kind which assembled at my father's old farmhouse and took up their abode in the "parlor" chimney. The flocks varied from a hundred to two or three times that number, and the usual time of assembling was early in September. Many a time at dusk I have watched the birds flying in a large circle above the house, and then all at once, even while I gazed, the mass would change form-those on the inner part gradually descending and the circle narrowing until it resembled an inverted cone with rapidly moving sides, which swept lower and lower, until the birds at the apex dropped into the chimney, soon to be followed by the whole flock. I saw something of the same thing a few summers ago in Princeton, New Jersey, although on a much larger scale; chimney swifts varying in number from twelve to fifteen hundred gathered each night, 


\section{The Chimney Swift}

apparently from the surrounding country, to roost in an old fashioned chimney in an untenanted house on Nassau Street. How one chimney can possibly hold so many birds is a mystery which I have never yet been able to solve! 


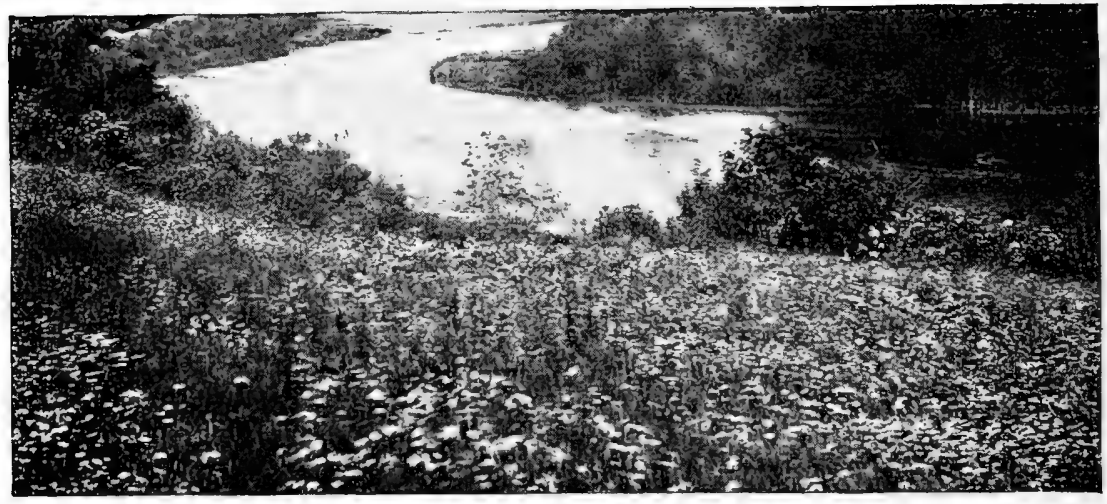

The Nesting Place of the Bobolink

\section{THE BOBOLINK}

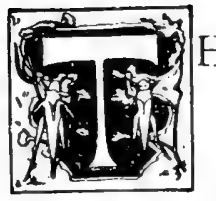

HE bobolink has a widespread geographical range, extending from the central portion of South America northward to the fifty-fifth parallel, and embracing all of the United States except the extreme western portion. It breeds from southern New Jersey northward to Nova Scotia and westward to Utah. Many are the names to which the bobolink answers : in the Southern States it is called the rice-bird, in the Middle States it is the reed-bird, while in the Northern States bobolink, May-bird, meadow-bird, butter-bird, and skunk-bird.

From the extreme southern limit of their winter home, south of the Amazon, the males, travelling in flocks of several hundred, start on their northward journey about April first, arriving in Florida toward the latter part of the month and some days before 


\section{The Bobolink}

the appearance of the females. Upon their arrival in the United States the males are in full song, and only one who has heard the wondrous melody of the bobolink can form any idea of the effect produced by several hundred singing in chorus. Beautifully as they sing in the North, they favor the South with still rarer treats. Audubon gives a description of one of these charming concerts in the following words :

"During their sojourn in Louisiana, in spring, their song, which is extremely interesting and emitted with a volubility bordering on a burlesque, is heard from a whole party at the same time; when, as each individual is, of course, possessed of the same musical powers as his neighbors, it becomes amusing to listen to a hundred or more of them beginning one after another, as if ordered to follow in quick succession, after the first notes are given by the leader, and producing such a medley as it is impossible to describe, although it is extremely pleasant to hear. While you are listening the whole flock simultaneously ceases, which appears equally extraordinary. This curious exhibition is repeated at intervals during the day."

About the first week in May the bobolink is with us, and he who has not had the pleasure of seeing and 


\section{The Bobolink}

hearing this superb bird has a great treat in store. If the bobolink concert belongs to the South, we have the solo work in the highest state of perfection, for immediately upon arrival at the North each male begins to pay particular attention to some plainly dressed little bobolink maiden, and for the lady of his choice he sings his most hilarious melody. I know of nothing more delightful on a May morning than to be near an old orchard, where the sweet scented blossoms are still hanging, and to watch the bobolink at his wooing. As you approach, the female is not to be seen, but she is, without doubt, down in the grass, while the male, in his beautiful coat of black and creamy white, is sitting upon the tallest bush by the fence; or, perchance, is swinging for a moment from the slender branch of an elm, before rising gracefully into the air and pouring forth such ringing, vibrating, tinkling, and rollicking notes as "tshe, 'tshe, 'tsh, 'tsh, 'tshe," and then circling right-about and setting sail for his former perch fairly shouting, "bob-o-lee, bob-o-lee, bob-o-linke."

After the wooing the happy pair selects a meadow, preferably near a running stream, and in a tussock of grass surrounded by plenty of green verdure a snug nest is constructed of bits of dried grass, collected by both male and female. The eggs, number- 


\section{The Bobolink}

ing from four to six, are of a grayish white with numerous blotches of umber upon them.

The nest is very difficult to locate-hours upon hours have I spent in trying to find one. In approaching the nest the male bobolink uses the same tactics as does the wild turkey; proceeding leisurely, by a most roundabout way and pretending great anxiety over some different locality if you approach too near his nest and mate. The female is the more wary of the two, guarding the approach to the nest with the utmost care; she always runs through the grass a long distance before taking to her wings, except when you stumble upon her by chance as she is sitting upon the nest.

While I was spending a summer in Princeton, New Jersey, studying the birds of that section, a friend of mine suggested a new method of finding the bobolink's nest, which was successful as compared with the old haphazard way of searching about in the grass wherever bobolinks were plentiful. The method was this: Having located a good bobolink meadow, it is necessary for two persons to operate together. They begin at one side of the field and walk across it abreast about seventy feet apart, holding between them a cord upon which are fastened sticks two feet in length and about eight feet apart. These sticks striking the grass frighten the sitting bird from the nest, and she flies 
directly up-instead of running through the grass as usual for some distance before taking to her wingsthus revealing her secret to the hunter.

As soon as the young are hatched the male begins the task of helping the female provide for the hungry, clamoring little family, and an arduous task it is, for even after the young leave the nest the parents provide food for them until they are able to find it or themselves. During this period the gaudy coat of the male bobolink disappears-it is moulting timeand the whole family is of the same sober color; the song also is given up along with the coat, and the only note heard is the call note, a metallic chink.

About the first of August most of the young bobolinks are on the wing, practicing for their long journey; the old and young become more clannish each day as they move slowly southward along the river courses, where the smaller flocks unite, making a vast army, which moves slowly toward the rice fields. The bobolinks now become fat and thousands of them are shot and sold in the markets. Their flesh is said to be very delicate.

It is toward the latter part of August they reach the rice fields, and for about six weeks there is no rest for the rice growers. The birds swarm upon the fields by millions-a scourge worse than a plague 


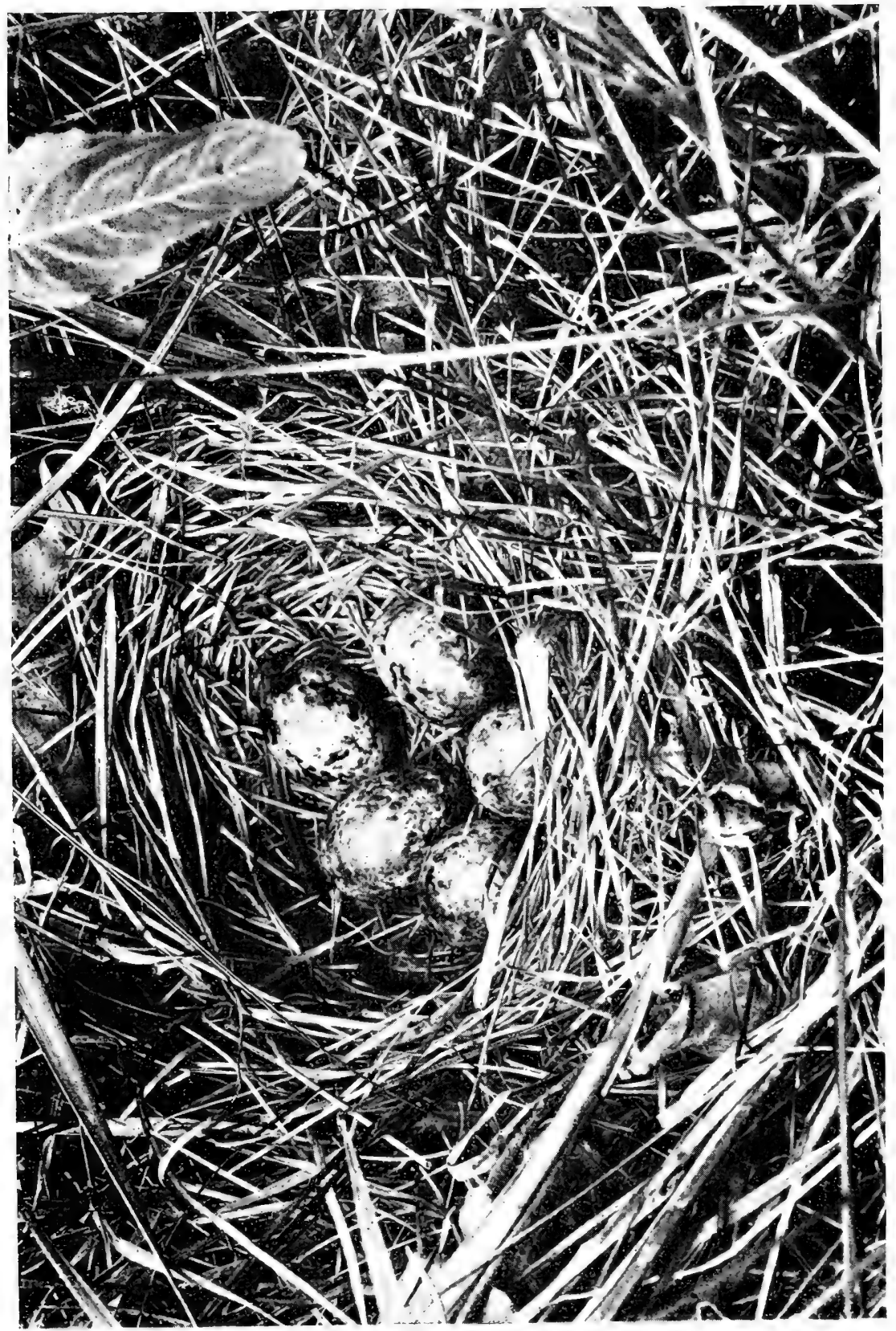


s...

$\because$

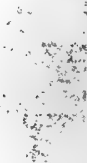




\section{The Bobolink}

of locusts. The loss caused by the bobolinks in the rice fields of the South must amount annually to over two million dollars. A greater part of this loss is incurred directly by the maintaining of "bird-minders," who patrol the fields from early morning until after sunset, firing guns and cracking the long lashes of whips. It is generally supposed that the firing of guns in the rice fields is for the purpose of killing the bobolinks, but, as the shot would destroy the rice, its object is simply to frighten the birds. Unless one has actually seen it, one cannot appreciate the amount of damage done by the bobolinks in the rice fields. To protect a hundred acres of rice from the bobolinks often costs from eighty to ninety dollars.

Besides the "bird-minders," other methods of preventing the ravages of the bobolinks have been tried, but thus far sooner or later all have failed. Among the various schemes probably the oldest and most often tried remedy is that of tarring the rice before it is sown. The tar on the rice is very distasteful to the birds, so that it has some effect in preventing the germinating rice from being pulled; but as the fields, except on the "uplands," are flooded as soon as the rice is sown, the long soaking renders the tar less efficient. The flying of kites over the fields was at first looked upon as a 
very effective remedy, but as the bobolinks soon became accustomed to them, they too proved ineffectual.

The turkey-buzzards are very plentiful in the South, and an attempt has been made to use them in frightening the bobolinks. For this purpose, poles from ten to twelve feet high were set up in various parts of the rice fields, at the tops of which were small platforms, and upon these meat was placed to attract the buzzards. These large birds flying about were mistaken by the bobolinks for hawks, and for a time this worked admirably, but as soon as the birds discovered their mistake the buzzards no longer alarmed them.

The bobolink question in the South is indeed a serious one, and the circumstances connected with it, though probably natural, are extremely interesting to a student of bird life. The bobolinks make havoc in the rice fields because man has selected for his own use the resting and feeding places which the birds have had since before the settlement of the country. If either is an usurper it is man. From the early bird history it is noted that the habits of the bobolink have remained practically the same; namely, the course of migration, the food habits, the love for the open meadow where it nests, and the points of departure and return to the United States are all unchanged.

When the forests of the Northern States gave place 


\section{The Bobolink}

to meadow lands, the nesting territory of the bobolinks was greatly enlarged, and was no doubt a factor in increasing their numbers.

During their spring migration northward from South America, the larger portion of them entered the United States by the way of Florida; the remainder, especially those occupying the western portion of the country, came in by the way of the Mississippi valley. In former times the Atlantic coast furnished the bobolinks with plenty of natural food, such as weed-seeds and wild rice. This was the condition in the latter part of the seventeenth century, when the bobolink was beloved by the people of the North and South alike. Meanwhile two conditions were slowly being brought about: meadow lands were increasing year by year in the North, and the growing of rice in the South was fast becoming a vast industry. The bobolinks now found beautiful nesting fields in the North, and, directly in the line of their old migration route, man was furnishing a bountiful supply of food in the way of the young rice, just beginning to appear above the ground. Another factor which should not be overlooked is, that, after the bobolinks' long sea journey, they are naturally exhausted upon reaching the Southern States, and so stop for a little period before they begin the long northern journey to their summer homes. This enforced rest 
brings them into the region of the rice, where, at the expense of the planter, they recuperate very rapidly. If the arrival of the birds was but a few weeks earlier or a few weeks later, the rice would escape uninjured.

During the southern migration opposite conditions prevail, although with similar results to the rice grower; the birds now take the land migration first, stopping in the Southern States to recruit their exhausted energies, caused by the rearing of the brood and by the long flight. This stop-over period in the South comes at the season of the rice harvest, furnishing the birds with an easy food supply-far easier than it would be to get it from the uncultivated fields-and this, coupled with the fact that the rice fields are limited in area, causes an individual loss to rice growers that would not be felt to the same extent if the crop were a general one, such as the oat or wheat crop.

That birds do not go much out of their old routes for food is well illustrated in the case of Texas. It is fast becoming a rice growing state, but as it is a little to one side of the path of the bobolinks that migrate through the Mississippi valley, the rice fields are not very seriously damaged.

We can easily see that to the southern rice grower the beauty of the bobolink, the sweet melody of its song, Bryant's poem-"Robert of Lincoln"-or the 
verses of Wilson Flagg can appeal but little. Poetry and sentiment do not often atone for individual loss, and the passage of the bobolink is truly a scourge to the South.

What are we at the North to think of our bobolink? To me the happy days of youth were made happier by the bubbling, rollicking melody of the bobolink, and I cherish the memory of it above all other bird music.

"Nuff sed June's bridesman, poet o' the year, Gladness on wings, the bobolink, is here." 


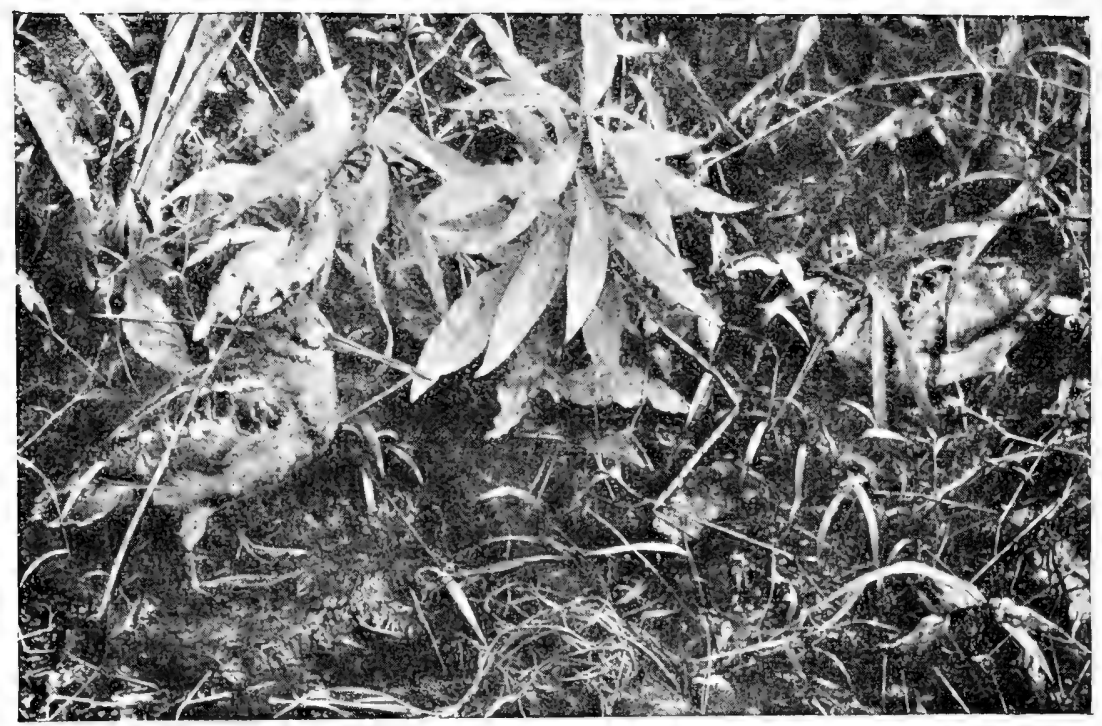

\section{THE WOODCOCK}

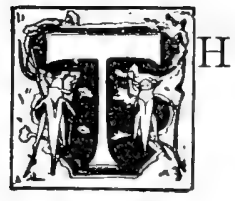

HE woodcock is one of our finest gamebirds. When flushed, it rises in a hurried manner to the tops of the bushes or glides through the underbrush for a few rods, drops instantly and, upon touching the ground, runs for a short distance and hides. This bird is often confounded with Wilson's snipe. The error is easily avoided, however, by remembering that the wings and the lower parts of the woodcock are of a reddishbrown color, while the wings of the snipe are barred with black and white, its throat and breast speckled, and its abdomen white.

The woodcock arrives in the latitude of New York, on its northern migration, about the second week in 


\section{The Woodcock}

March, taking up its abode in boggy and swampy places surrounded by bushes. Being a nocturnal bird it remains in concealment during the day, coming forth towards evening in search of food, which it obtains by boring into the soft soil for larvæ and worms, or by turning over the dead leaves in search of insects. The sensibility in the extremity of the bill is developed to a most remarkable degree; in fact, in obtaining its food the eyes of the bird are used scarcely at all.

During the season of courtship in April the male indulges in a curious performance; this performance takes place occasionally in the morning, but more particularly in the evening, and consists of a spiral flight very similar to that of the lark. While the woodcock is ascending a feeble note is heard, but when descending the volume of the tone increases, and as he approaches the ground it assumes the character of a song; when he reaches the ground the song ceases, the bird giving utterance to a few deep guttural notes, not at all in keeping with the delightful aerial serenade. This performance is repeated several times during the evening.

The nest is located on the ground near a swamp, though occasionally I have found one in a dry woodland. Unlike most birds the woodcock spends very 
little time in making its nest, which consists simply of a slight depression lined with leaves or grass. Probably the wind had more to do with the collection of the nesting material than did the mother bird, and the shape of the nest is more largely due to the pressure of the body than to any real arrangement of the material. Here, in this carelessly constructed home, the mother bird deposits four buff colored eggs, spotted with brown or lavender; the situation of the nest and the coloring of the bird and the eggs form a most perfect example of protective coloration.

The woodcock, ordinarily a very wild bird, can be easily approached during the period of incubation, or before the young can fly. This may be accounted for in the woodcock, and in other animals as well, by the mother love, so strong in nearly all of them. Even before the eggs are hatched the mother woodcock, in luring you away from the nest and eggs, makes use of the same stratagem that she later employs in protecting her chicks. The ruse is this: When the bird is flushed from her nest, she flutters about as though one wing were disabled. Your first impulse is the natural one; that is, to catch the bird. You step forward, and as you are about to pick her up, she flops just out of reach; one more effort on 


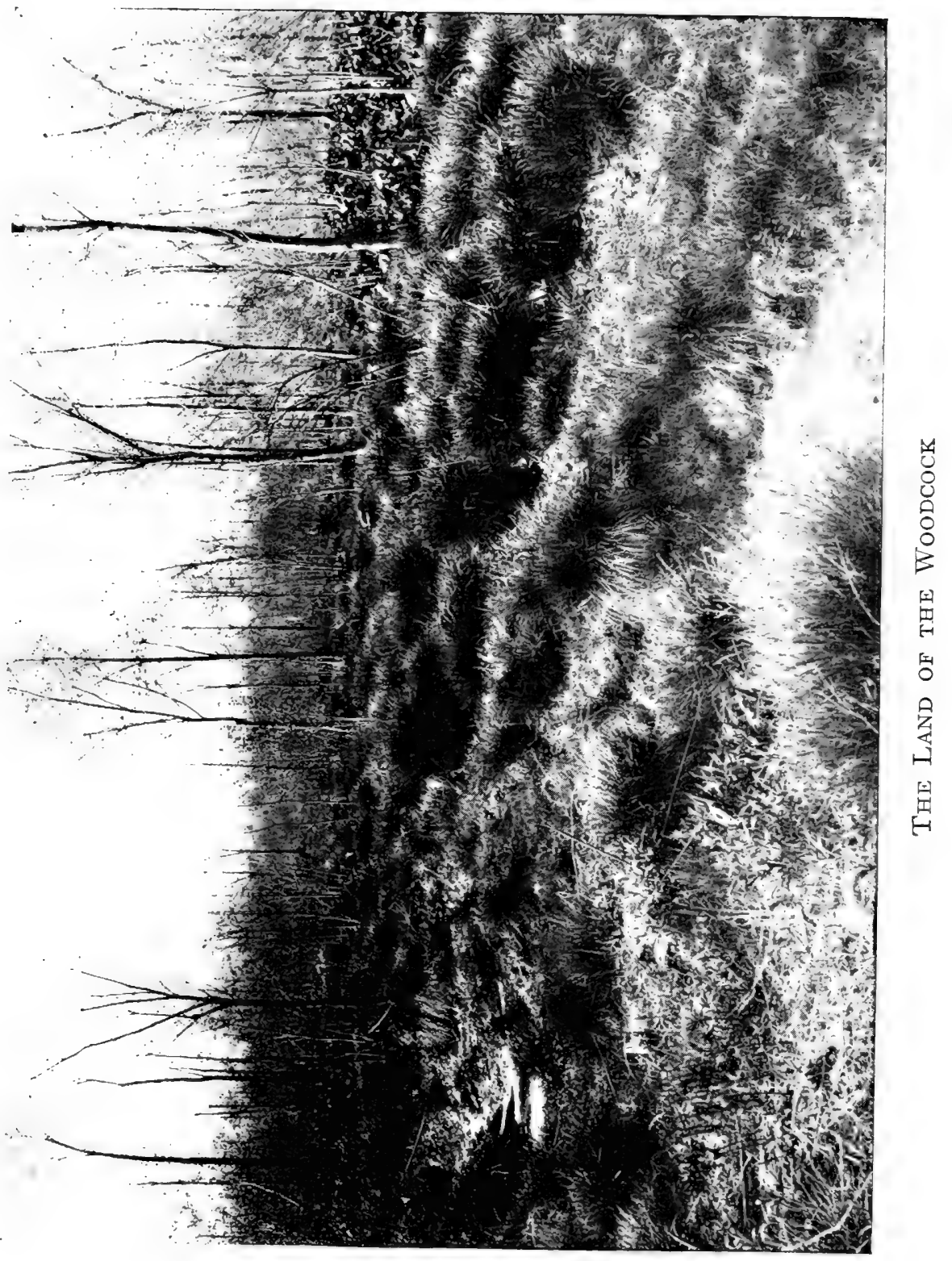





\section{The Woodcock}

your part and she must surely be yours, but somehow she is always a little beyond your grasp. Finally, with a quick movement, she is on the wing and away, and you realize that you have been fooled by a mother woodcock. Your admiration for the bird and the animal creation in general has increased, and you are the better for having seen this proof of unselfish bird love. By this ruse the mother has led you some distance from the nest and eggs, and the chances are that you may not find them. If there are chicks and they are large enough to run, they have hidden themselves long before your return.

The chicks are fluffy little fellows, so like in color to the brown leaves on which they first open their eyes upon the big, strange world, that it is almost impossible to detect their small crouching forms. So strong is the instinct of concealment that you may find the little fellow prone upon a leaf, with eyes sometimes closed, and you may touch him without the slightest movement on his part. Even lift him gently in your hand, and he still obeys that wonderful something which we call instinct. I have been told that if the nest has often been visited and the old bird frequently disturbed, as soon as the eggs are hatched she carries the chicks away, one at a time, in her claws, to a place of safety. 


\section{The Woodcock}

By early autumn the woodcock families have spread out into the country; and here the cornfield is their favorite resort, because of the moist condition of the soil which supplies abundant food for them. Later in the autumn, during October and November, the woodcocks that have escaped the gunners migrate to the Southern States, probably more on account of the failing food supply than because of the cold weather.

I wish to illustrate more fully the protective coloration and the "apparent tameness" of the woodcock by my experience in photographing one. I asked a. friend who lived in the country to notify me when he found a woodcock nesting. About the twentieth of April I received word that he had found one; so the next day I joined him, and with a long-focus camera and twelve plates we set out to photograph the woodcock.

The nest was in a hedgerow between two fields near a swamp, and as we neared the spot my friend stepped forward to point out the sitting bird. But although he had been there three times, it was several minutes before he was able to find her, so closely did her markings harmonize with her surroundings. My friend has the experienced eye of a hunter, has known the woodcock for forty years, and has seen dozens of nests; so he was puzzled to know why it 


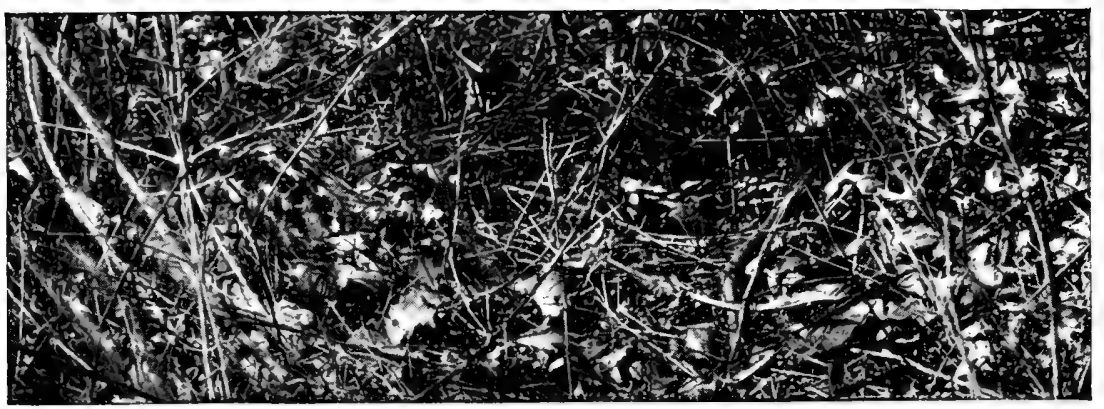

First Photograph

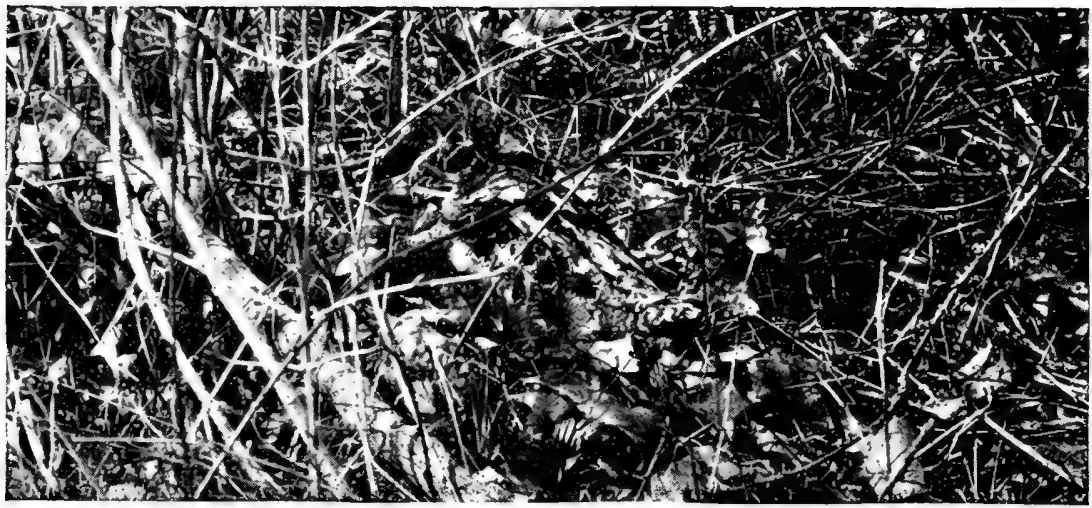

Second Photograph

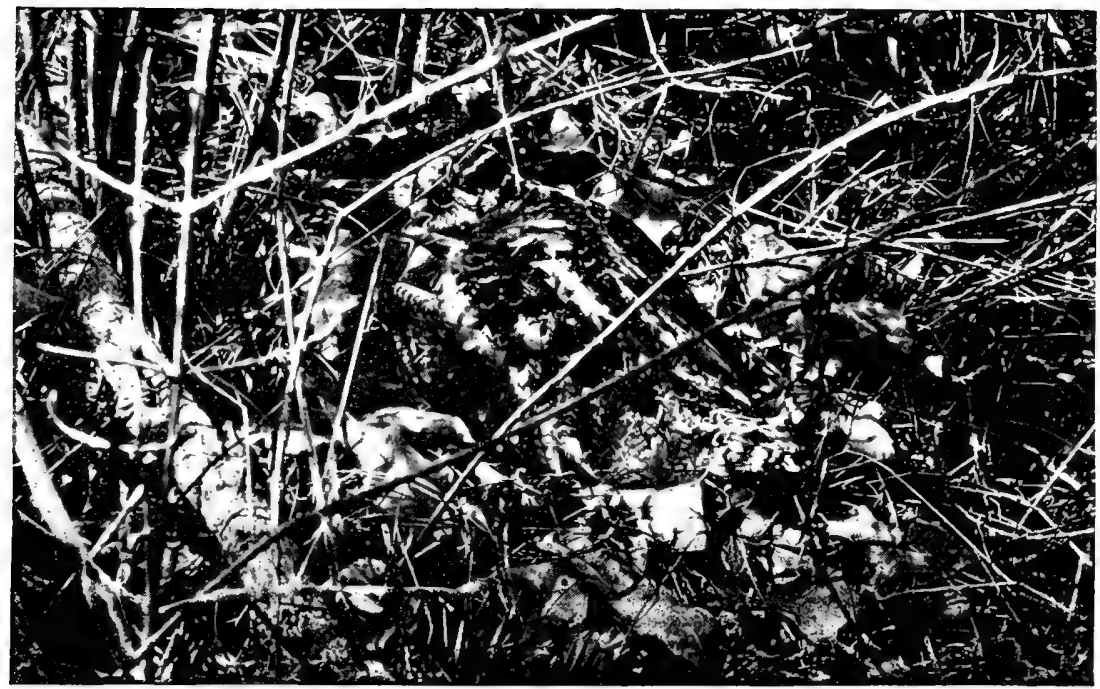





\section{The Woodcock}

took him so long to find this one. He finally decided that it was owing to the position of the bird on the nest: when he had seen her before she was facing the north, now she was facing the south. We were standing within twenty-five feet of the bird, but I had not yet seen her, and even with the help of my friend it took me fully a minute to locate her. After she was once separated from her immediate surroundings, however, it was easy to see her, for, the nest being so shallow, the full body of the bird was in view.

The next thing to be considered was the photographing of the bird, and that, too, with a tripod camera. How near the camera could be placed without frightening her away was problematic. My friend suggested that I probably could not approach nearer than eighteen or twenty feet. Accordingly the camera was set up at about this distance and two exposures made. I then walked nearer the bird and remained for half an hour, chatting meanwhile with my friend, who was about thirty feet away. As the bird did not stir, I believed that I could photograph her at closer range than before, so $I$ set the camera in position and made two exposures.

My friend could scarcely believe what he saw; never before had he seen a woodcock so closely ap- 


\section{The Woodcock}

proached. I walked to within eight feet of the bird, where I remained for an hour before attempting to take another photograph, that the bird might become thoroughly accustomed to my presence.

By this time I was really wondering how near I could approach the bird before she would leave the nest. I went closer, and, following my former tactics, that of consuming plenty of time before photographing, I finally completed a series of five photographs, approaching the bird as closely as I wished. I even broke and removed twigs and weeds that were within six inches of the bird's back, and later my friend put his hand within an inch of her head before she moved. Then she squatted a little lower, and as his hand was brought nearer she flew on rapid, vibrant wings, wabbling as only a woodcock can wabble-as beautiful a sight as any bird-lover could wish.

There were four eggs in the nest, which were quickly photographed, and we retired that the mother bird might return and complete the incubation, for which she had so bravely endured, for half a day, the presence of two men and a camera.

The second day after, there were three eggs and one fluffy little woodcock. As I believed the other eggs would be hatched, I intended to return the following day and photograph the four; however, I was detained 


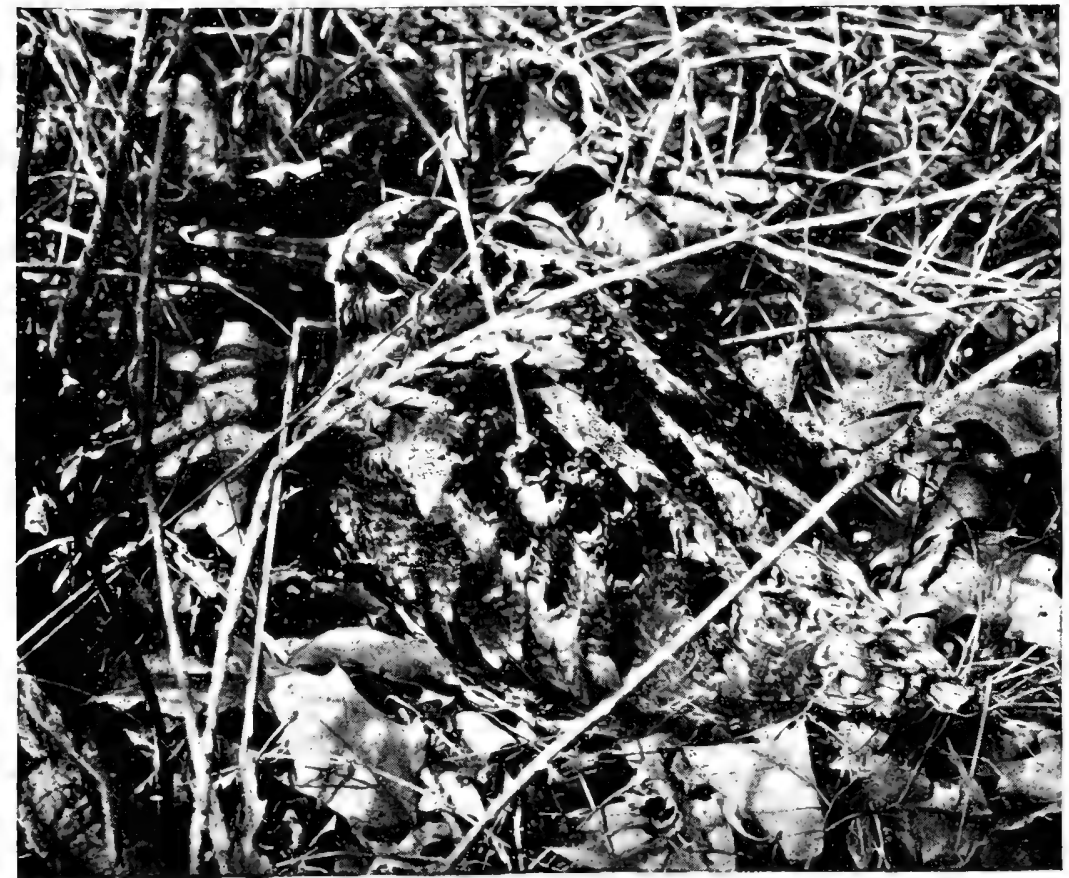

Fourth PhotograpH

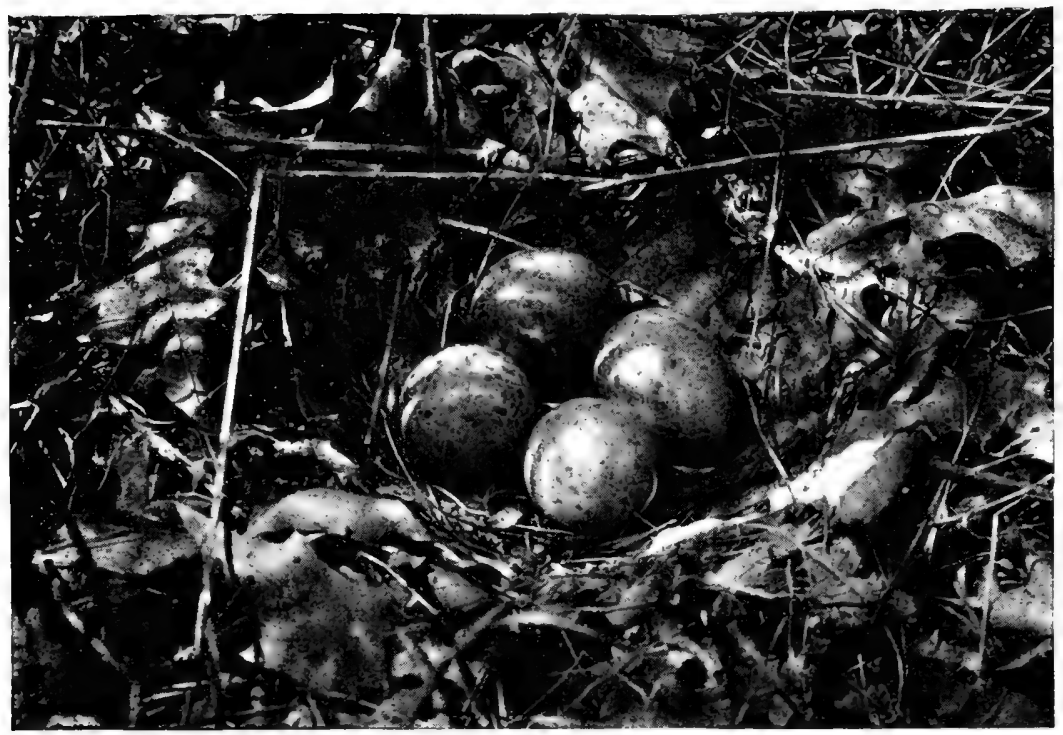

Fifth Photograph 



\section{The Woodcock}

yet another day, and when I arrived, instead of four little woodcocks, there were only the remains of the once beautiful eggs. My friend strongly asserted that the mother had carried the chicks away to a place of safety. Be that as it may, a feeling of sadness came over me as I looked upon the empty nest, never to be tenanted again. I sincerely hoped, now that they were gone, that the gentle-eyed mother and the four little chicks were far beyond the reach of dog and man, in the fastnesses of the great swamp close by. And in my fancy as I wander through the swamp, when the sumac is crimson and the maple is aflame with russet and gold, I imagine that the fine holes bored in the mud by long bills were made by our woodcock family. 


\section{CROWS}

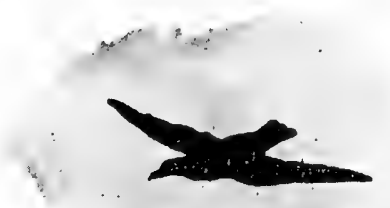

HE range of the com-
mon crow extends
from the southern extremity of the United States north to a latitude of about sixty-four degrees. Throughout this vast territory the bird is most abundant in the East, while in the West it is rare in many localities, especially in the desert regions. Within this territory are, besides the common crow, three other well defined varieties; in Florida the Florida crow, along the Atlantic coast from Massachusetts southward the fish crow, and on the Pacific Coast from Washington northward the Northwest crow. Crows are supposed to be permanent residents throughout their range, but this is not the true condition of affairs. It is probable that in the northern portion of their range the crow population moves southward somewhat, thus leaving a few crows everywhere, except in the extreme north.

Crows are very clannish, particularly during the 


\section{Crows}

winter months, and even in the nesting season they are separated only by short distances. This gregariousness leads them to form during the winter what are commonly called crow roosts, which are nothing more nor less than the crows of a certain section of the country roosting in one place. There is no uniformity as to the location of the roost, for it may be in evergreen or deciduous trees, and again among the reeds and grasses. The evergreens would seem to form the best protection from storms and high winds, the most northern roost that I have seen being so located.

In the early morning the roost is vacated by the crows, and they spread out over the surrounding country in search of food, going usually in bands. These bands quite uniformly take the same direction in going to their feeding grounds and in returning to the roost-preferably following a valley or a range of hills for protection from the winds. Toward evening the crows arrive in the neighborhood of the roost, and just before dark they settle upon it in a body. The various bands are, to some extent, under leaders. This is very common among gregarious animals.

Some roosts contain as many as fifty acres, and probably in a roost as large as this the crows number as many as a hundred and fifty thousand, or even more. The crow roost with which I have been most 


\section{2}

\section{Crows}

familiar was located in Marble's Woods in the town of Columbus, New York State. It was but a short distance from my early home, and many times I have visited it. The woods proper consisted of from twelve to fifteen acres, somewhat less than half of which were hemlocks. In these hemlocks the crows had their roost, a small one, to be sure, but one which was in every way characteristic. One band had a decided leader whom I came to know very well. He was easily distinguished from other crows because he had white feathers in both wings. "Old White Wing," as he was known, came the nearest to being one of Dr. Godman's bad crows that I have ever known.

About November first the crows began to congregate in the roost, and by December it had reached its normal size. In March the crows began to leave the roost, and by the first week in April they had all departed, except those intending to nest there. Their arrival and departure varied considerably with the season, and a mild winter had its influence upon the regular attendance.

During very severe winters the crows had little to feed upon and the death rate at the roost was correspondingly large. The foxes, hawks, and owls came in for their share of crows, as these animals were all very plentiful about the roost. The great horned 


\section{Crows}

owls were very numerous, and I have reasons for believing that they frequently visited the roost at night. Hunters take advantage of the roosting habits of crows and station themselves along the various routes leading to the roost, killing and wounding several in a single day; often, too, they make attacks upon the crows after they have settled quietly for the night. Usually several hunters combine for a night attack, and the net results may be two or three hundred crows killed, and perhaps as many more wounded.

Crow roosts are less frequent now than in the days of Audubon, or even before. The destruction of the forests has probably had considerable to do with lessening the crow population, while within the past twenty-five years the millinery trade has used thousands of crows' wings. However, just at present the demand for crows' wings is not so great as it was a few years ago.

The question has often been asked, "Why do crows form roosts at all?" There have been several answers to this question, none of which I believe to be quite satisfactory. By some it is supposed that the birds collect for warmth, and for protection from their enemies; by others, that the particular places selected as roosts afford better perching facilities for the long winter nights. On the contrary, I believe 
that if some one can tell why crows are sociable birds, the question as to why they form roosts will be answered.

The plumage of the crow is black, and his character has been, and still is, painted of a hue equally dark. The habits of the crows of a hundred years ago and those of the crow of to-day are not the same, but most writers seem to think it necessary to inflict upon the present crow the bad reputation of past generations. Birds considered in relation to man are of two general classes, those that are helpful and those that are harmful. According to the popular idea, the crow belongs decidedly to the latter class. I believe the wrongdoings of crows to have been exaggerated, and that the real harm done is very much less than is supposed. To judge the crow, or any other animal in its economic relations to man, from a scientific standpoint, we must know what it lives upon. This will largely determine whether it is beneficial or harmful. However, in one part of the animal's range this may put him in one class, while in another part he will appear in the other.

The crow destroys a considerable number of fieldmice, and in particular the young of the short-tailed variety, which builds its nest upon the surface of the ground. Even tame crows are very fond of mice, seeming to prefer them to almost any other kind of 
food. Wild ones that have been caught show a similar liking for mice. A friend of mine once captured a young crow about two-thirds grown. For some reason the crow refused to eat, and would not take nourishment except when it was forced down his throat. One day a boy caught an old fieldmouse and six little ones, and gave them to my friend for his crow. As soon as the crow saw them, his appetite seemed to return, and very quickly he disposed of the whole family. This would seem to indicate that the crow had had previous knowledge of the flavor of mice. Now if this habit of feeding upon mice is as common among crows as I believe it to be, it must certainly be of considerable economic value throughout the farming region of the United States; for as it is, the different varieties of fieldmice cause millions of dollars of damage annually throughout the region inhabited by the common crow.

It is probable that young rabbits, the cottontail in particular, are often killed by crows, and the same may be said of the ground squirrels and gophers. The crow also catches a few reptiles, fishes, and invertebrates of various kinds, besides annually destroying a large number of insects, among the most harmful being cutworms, weevils, ground spiders, click beetles, 
May beetles, and grasshoppers. Seeds of various kinds are also eaten by the crow, although upon the whole this is probably rather beneficial than otherwise.

To be perfectly fair, however, I must mention some of the most flagrant crimes of the crows. Probably the one most talked about among ornithologists is that of the destruction of the eggs and young of wild birds. This is one of the crow's worst habits. But his bad reputation has grown more out of the farmer's grievance against him-that he steals corn. It is true that the crow does sometimes pull up the tender blades for the kernel at the root, but even here he is condemned upon appearances rather than upon actual facts. In other words, the farmers accuse the crows of pulling corn until it is four or five inches in height, every time they alight upon a cornfield. Now the fact of it is that the crows are after insects of various kinds and other food, rather than the corn, although the corn may be pulled at the same time.

A farmer acquaintance of mine was greatly distressed over the crows that visited the field in which he had planted corn. He talked so much about it that I visited the field several times both before and after the corn was up, and I saw but slight evidence that the crows were disturbing it. I told him so, but he seemed to have little confidence in my theory that 
the crows were after insects, rather than corn. One morning I happened along just after he had shot two crows in the cornfield, and his remark to me was something like this: "There are two of your innocent, insect-eating birds, but they'll never pull any more corn for me."

"Well," I replied, "I'm sorry, but I don't believe that they pulled very much of your corn."

The farmer quite warmly remarked: "I sat by the fence and watched them, and what I see with my own eyes is enough for me."

I obtained from him permission to dissect the crows, and in the stomach of one I found the unmistakable remains of a field mouse, several cutworms, remains of various insects, a little vegetable food, and one kernel of corn. The other stomach contained several cutworms, remains of other insects, traces of vegetable matter, but no corn. The farmer had agreed to believe his eyes, but now he was almost willing to doubt them.

On the ground throughout the field were plenty of withered stalks of corn an inch and a half to three inches in length; this the farmer believed to be the work of crows, but it was the work of cutworms, as I clearly proved to him upon visiting the field; and in ten days the whole field of corn was nearly ruined 
by these insects. Crows cannot always be as easily proven to be innocent as in this illustration, for sometimes they do considerable damage to cornfields, and occasionally slight damage to oat and wheat fields.

The cornfields may easily be protected by scarecrows, by twining it, or by tarring the corn. Either of these methods is fairly effectual where crows are quite plentiful.

After carefully considering the food of the crow throughout its range, and comparing the evidence for and against, the weight of the evidence seems to be in favor of the crow. Many of the wrongdoings attributed to crows years ago cling to them to-day, but circumstances have changed, and the facts are true only in part. Over seventy years ago Dr. Godman wrote as follows:

"Where food is at any time scarce, or the opportunity for such marauding inviting, there is scarcely a young animal about the farmyard safe from the attacks of the crow. Young chickens, ducks, goslings, and even little pigs, when quite young and feeble, are carried off by them. They are not less eager to discover the nests of domestic fowls, and will sit very quietly in sight, at a convenient distance, until the hen leaves the nest, and then fly down and suck the eggs at leisure. But none of their tricks 


\section{Crows}

excited in me a greater interest than the observation of their attempts to rob a hen of her chicks. The crow, alighting a little distance from the hen, would advance in an apparently careless way toward the brood, when the vigilant parent would bristle up her feathers and rush at the black rogue to drive him off. After several such approaches, the hen would become very angry and would chase the crow to a greater distance from the brood. This is the very object the robber has in view, for as long as the parent keeps near her young the crow has very slight chance of success; but as soon as he can induce her to follow him to a little distance from the brood, he takes advantage of his wings, and before she can regain her place, has flown over her and seized one of her chickens. When the crow tries to carry off a gosling from the mother, it requires more daring and skill, and is far less frequently successful than in the former instance. If the gander be in company, which he almost uniformly is, the crow has his labor in vain. Notwithstanding the advantage of flight and superior cunning, the honest vigilance and determined bravery of the former are too much for him."

This might have happened seventy years ago, but the habits of crows have changed, although they have not lost their cunning. There is scarcely a more 
wary bird, or at the same time a more teachable one, than the crow. The crow is perfectly foolish about some things and very wise about others. My experience with crows at "the blind" very well illustrates the last statement.

In the month of March I was tramping through a field near a piece of woods about a mile from Chatham, New Jersey, when I heard a great commotion among some crows and occasionally the report of a gun. I was interested to know what was going on, but an elevation of ground prevented me from seeing the birds. Changing my direction a trifle, in two or three minutes I was in full view of a flock of probably from twenty to twenty-five crows, most of which were circling about in the air, the remainder being perched upon tall trees. The elevation upon which I was standing gave me an unobstructed view over a small meadow, and at the farther side, near a fence skirted by bushes, I saw the reason for the cawing of the crows. About six rods from the fence, in the open meadow, was a post about five feet high, upon the top of which was perched a large bird, probably a hawk or an owl. I had not fully taken in the situation, when one of the circling crows made a dive for the bird on the post, probably coming within a foot or two of it. It was just starting on the incline up- 
ward, when a shot startled me and the crow fell dead. I was about sixty rods away, but the crows did not heed me in the least. Something which an old hunter told me some years ago about shooting crows from "a blind" now passed through my mind, and I looked for a blind by the fence, near the bird on the post. All that I could make out, from where I was standing, was a heap of what appeared to be cornstalks among the bushes. I was thoroughly interested in the scene before me, and seating myself upon a large stone, I took out my field-glass and began a most careful study of the situation. Just then two crows made a dive for the owl, and one of them was shot. It was now all clear to me, and I waited an hour for the "wing-hunter" to come from his place of concealment. When he did, I made his acquaintance, and soon he was telling me "all" about crows and their wonderful intelligence. The morning had netted him six crows, the wings of which he disposed of to a New York firm at fifty cents a pair, to be used later in the decoration of hats for women.

The bird on the post proved to be a mounted great horned owl, and the heap of cornstalks covered the framework of a "blind." With the consent of the owner, I soon began my own study of crows from this 
cornstalk blind. One morning before daylight I placed the owl upon the post, and concealed myself in the blind. Just at the break of day I heard the distant cawing of crows, and a little later a crow came flying over the meadow and espied the owl. Circling high in air, he uttered three short, sharp, and loud notes of "Caw, caw, caw!" This he repeated several times in the same manner. In five minutes other crows had joined him, and soon there were twenty, or more, circling, cawing, and diving at the owl. This continued for about two hours, until the band finally dispersed. During this time twelve crows had been within easy gunshot.

A few days later, just at dark, the owl was placed upon the post. In the morning, shortly after the crows had collected, I arrived upon the scene and went into the blind. The crows remained about for some time, but not one came within gunshot. The owl was again taken in, and several days later was placed upon the post at dark. In the morning I appeared with a friend, and we entered the blind together. The crows kept out of gunshot for half an hour, and then my friend left. Within a short time the crows were back again in full force, diving at the owl within easy gunshot. These manœuvres, with various modifications, I repeated several times, 


\section{Crows}

thus becoming quite familiar with some of the phases of crow reasoning; but I failed to discover that they can count, as has been so often stated by writers.

The crow is a very entertaining bird in captivity, and I do not know of another bird that will become

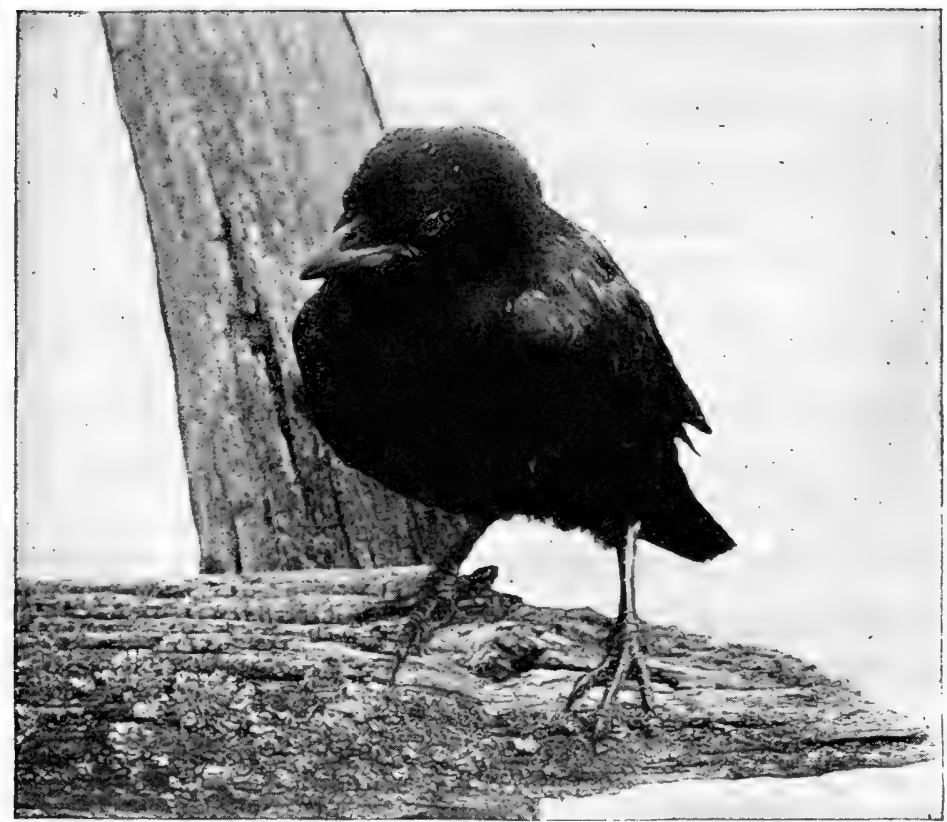

"JIM"

so tame and yet at the same time be so full of pranks. If you have never had any experience with a tame crow, you cannot appreciate the fulness of the word "pranks," therefore I wish to speak of a pet crow, familiarly called Jim, that I knew very well.

It will be remembered in the story of "Old White 
Wing" that during a severe storm his nest was so badly shaken that one of the young crows fell to the ground and was found next morning nearly dead. A farmer lad carried the unfortunate bird home in his hat. It was the work of but a few moments to find a small box, into which the boy put the bird, wrapping about its body soft cloth and then placing the box near the fire, just as he had seen his mother bring to life half-drowned chickens. In an hour the crow seemed quite lively; and needed to be fed. After several attempts to take some bread softened with milk, the bird finally succeeded in swallowing a little, and in a few days one would have thought that he had always been accustomed to hand feeding, so readily did he take to it.

The friendship between the boy and the crow grew day by day, but the elder members of the family looked upon the young bird with little favor, doubtless remembering the corn pulling habits of crows. The box in the kitchen soon proved too small for the growing bird, and the constant sight of the crow provoked the old farmer, and so the boy constructcd for his pet a more comfortable box in the woodhouse. With good care and plenty of food Jim grew rapidly, and in a few weeks he would follow his young master about the farm. The crow took an intense interest 


\section{Crows $\quad 265$}

in everything, and never lost an opportunity for playing tricks upon the cat or the dog. The dog, which was old and spent most of the time in lying about in comfortable places fast asleep, had in his young days the misfortune of losing about two-thirds of his tail, leaving at the end a conspicuous bald spot. The rogue of a crow never missed the opportunity of giving this spot a vigorous peck whenever he found the old dog enjoying solid comfort.

Jim spent a great deal of his time in the hayfield, and as he would eat grasshoppers until he could scarcely fly, he began to gain favor with the family, which was very gratifying to his young master. During August, however, he sometimes visited the fields where the wild crows were feeding, and soon new traits of character began to develop. One day he came home with a small blue egg shell and put it with his curios in the woodhouse where he had passed his early days. These curios were rather a motley collection-pieces of glass and broken dishes, a few large buttons, and an old pair of eyeglasses.

As time went on Jim became a well developed specimen of the crow family. One Sunday morning after the farmer had done his usual tasks, shaved, taken the weekly paper, and seated himself in an easy chair, he reached for his spectacles, which always 
lay in one particular spot upon a small table by the window, but they were not there. He searched everywhere without finding them, neither could the good wife find them, and there was nothing in the world that so ruffled the good man as to have his spectacles mislaid. Each member of the family was crossexamined in regard to the missing spectacles, but no one could give the desired information.

The farmer finally threw down his paper in disgust, thinking that if he took a walk to the Spring Lot, to see the young stock, he would perhaps feel better. As he passed through the woodhouse he caught sight of Jim flying in at the door with something in his beak. Contrary to his custom he stopped to see what it was, and to his surprise he saw his spectacles. Quickly he closed the door, and seizing a broom, started for Jim. The bird flew to the top of his box, still holding the spectacles in his beak, but had scarcely alighted, when, just escaping a wellintended blow, he immediately took to his wings. The only window was closed, but as the broom was sweeping in all directions, Jim, in his effort to escape, flew against one of the panes of glass with sufficient force to break it, thus saving himself, but leaving the spectacles hanging on the sash with one of the glasses broken. 
This last act was the climax of a long series of escapades, and the result of it was that the boy was forced to dispose of his pet. Jim was finally persuaded to stay at a neighboring farm, where, under varied conditions, he showed his adaptability to new circumstances, by developing other tricks. 


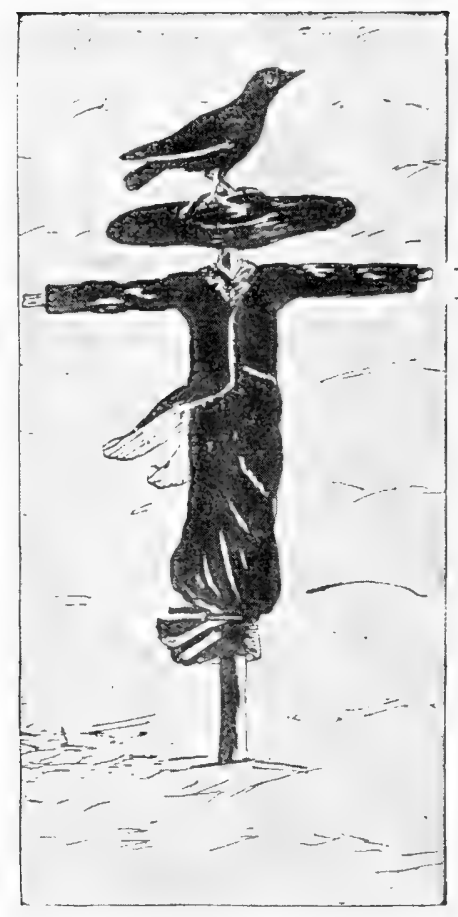

\section{OLD WHITE WING}

HE sun had crossed the line, the snow was beginning to melt, and now and then the call of a robin was heard. It was "sugar time"; the buckets were hung, and the large pans on the arch were sending volumes of sweet vapor into the air until the little slab house was almost hidden in wreaths of white smoke.

Early morning found the farmer folk astir with the promise of a good "sap day." From the grove of hemlocks back of the sugar bush came the familiar "Caw, caw," of the crows. They, too, had a promise of something good, for across the meadow from the barns came the glad news that food in plenty was awaiting them. Soon a dark speck could be seen in the sky in the direction of the hemlock grove, then 


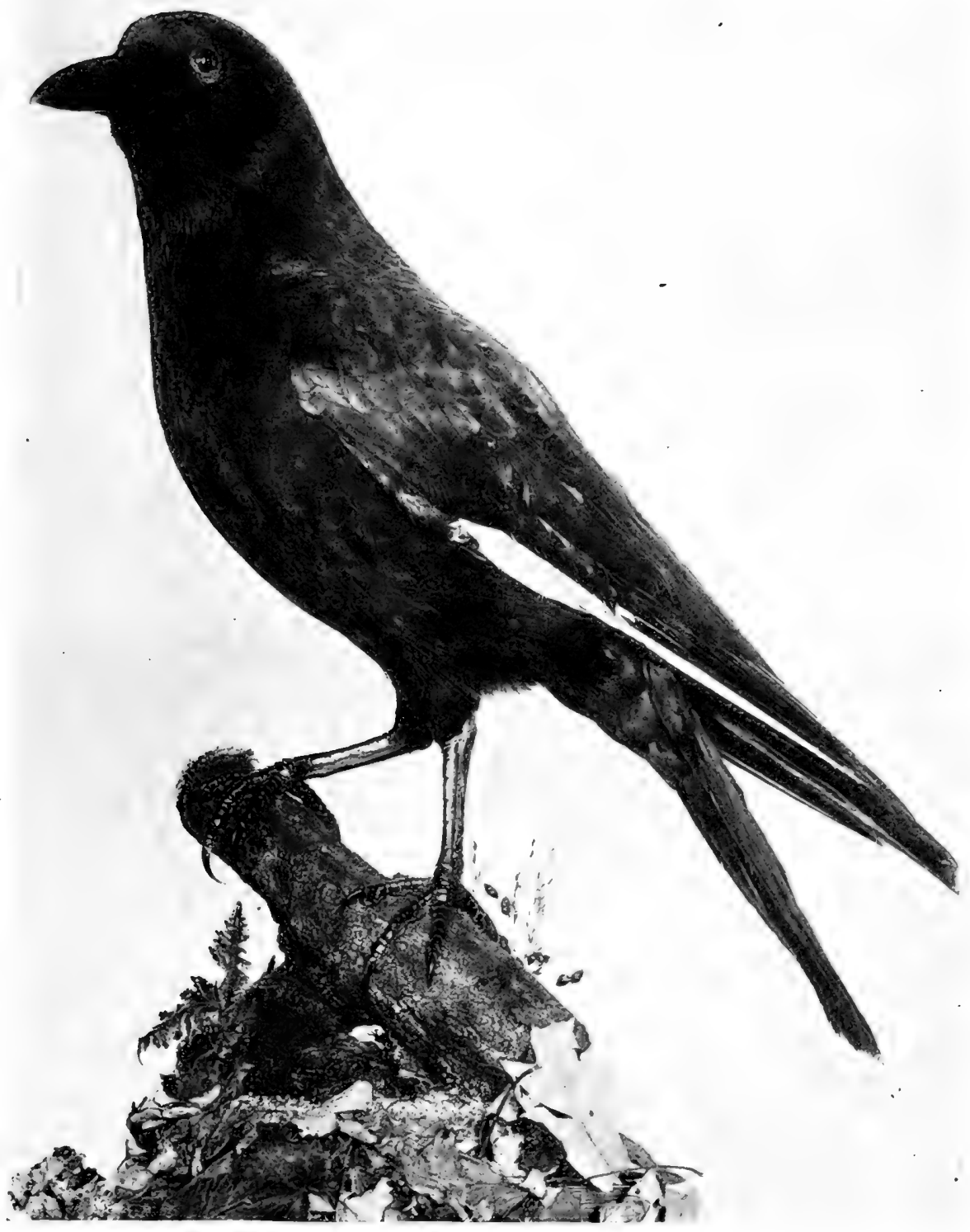

$$
\text { "Old White Wing." (Mounted) }
$$





\section{Old White Wing}

another, and still another, until a dozen or fifteen appeared, gradually taking the form of crows. Some alighted on fence stakes, others on the lower limbs of trees, but apart from these, one perched alone on the top of a tall tree. There being no stir about the barns, the crow on the tree top flew in a half circle a little nearer, making a close inspection, and seeing no apparent danger, returned to his former perch. This crow seemed to be the leader of the flock; he was larger than any of the others, and in each wing there were several white feathers. This was the first time I had ever seen this crow, but I learned later that he was not a stranger to the farmer folk, for he was known throughout the Hollow as "Old White Wing." $\mathrm{He}$ had led many a cornfield raid, had carried off not a few chickens, and was a notorious destroyer of birds' nests. Short sighted man had counted only his crimes and had not measured the good he had done in disposing of mice, moles, grasshoppers, and Maybeetles.

Out from the flock of crows flew one, straight for the monarch on the tree top, and alighted near him. Evidently this was his mate, and she seemed his equal in every way except in size. A quiet little dialogue in the crow language was indulged in, and after a 
few minutes the leader left the perch, and, flying low until he neared a tall apple tree which stood within a few yards of the barnyard fence, sailed with curved wing to the topmost branch. After this reconnoitring, as all seemed quiet, it was not long before there were three crows in the barnyard feeding on the dead body of a calf. During all this time not a sound in the crow language could be heard. Suddenly a barn door creaked on its hinges, and almost simultaneously came the warning cry of danger from the sentinel and the report of a gun, followed by the death struggle of one of the crows. Immediately the remainder of the flock followed Old White Wing in a retreat to the grove of hemlocks.

It was during the spring and early summer before my acquaintance with Old White Wing that he had become most notorious. Once he had caught a chicken while the good housewife was feeding the brood. Scarecrows seemed to have no effect upon him; he could read the delusion at a glance, and from the top of one would watch and direct his band while foraging. Poisoned corn was scattered over a field which he and his band had visited scores of times, but he was not deceived. He had once nearly lost his life by this means, and Old White Wing never needed a lesson twice. Snares, traps of all 


\section{Old White Wing}

kinds, and men with guns he had often warned the different members of the band against, and so no wonder they thrived and increased under the leadership of this king among crows. The superstitious believed that he bore a charmed life, and many were the stories told of his wonderful intelligence and his narrow escapes.

Any one who has been fortunate enough to become acquainted with our wild, feathered friends must have noticed that there are natural leaders, especially among the gregarious kinds. Old White Wing had long been leader of this small but wary band of crows which passed the winter months in the hemlocks, separated in pairs during the nesting season in summer, and reassembled again in autumn.

The nesting place of Old White Wing had long been a mystery to the farmer boys, for, search as they might, not one had been able to locate it. Every lad in the Hollow knew the nesting habits of the turkey, the bobolink, and the meadow lark-does a crow know even more than these birds? The boys were especially anxious, too, to find this nest, for there was a bounty upon the head of Old White Wing-the penalty which wild animals must suffer for being able to care for themselves, - and it was believed that if his summer home could be discovered, 


\section{Old White Wing}

family cares lessening his well-known vigilance, he might be captured.

During the spring I made a close study of Old White Wing and his band, and I soon became convinced that he was no common crow. The third week in March the band became very noisy, and soon there were signs of departing for their summer homes. The noise was due to a general meeting of the crows of the roost, and a kind of introduction among the young crows, preliminary to mating. The males were performing strange gymnastics in the air and indulging in short contests of flight before their admiring lady birds. Now was the season for me to discover Old White Wing's domestic secrets.

Early one morning, as I was returning from a search for owls, and was about to emerge from a deep ravine at the foot of Hall's Hill, I saw a crow flying up the valley toward the place where I was standing. The sides of the ravine were covered with deciduous and evergreen trees and a dense growth of underbrush, and farther up the ravine the large trees were mostly hemlocks, an ideal situation for a crow's nest. As I had not been seen by the bird, I stepped behind a cluster of trees and waited. In a few moments the crow passed, and I saw that it was Old White Wing. I believed that now I had a 


\section{Old White Wing}

clue to his nesting-place. I did not follow, but quietly left the ravine. About ten o'clock I saw him and his mate near the sulphur spring in the meadow, and in a few days the winter roost was abandoned.

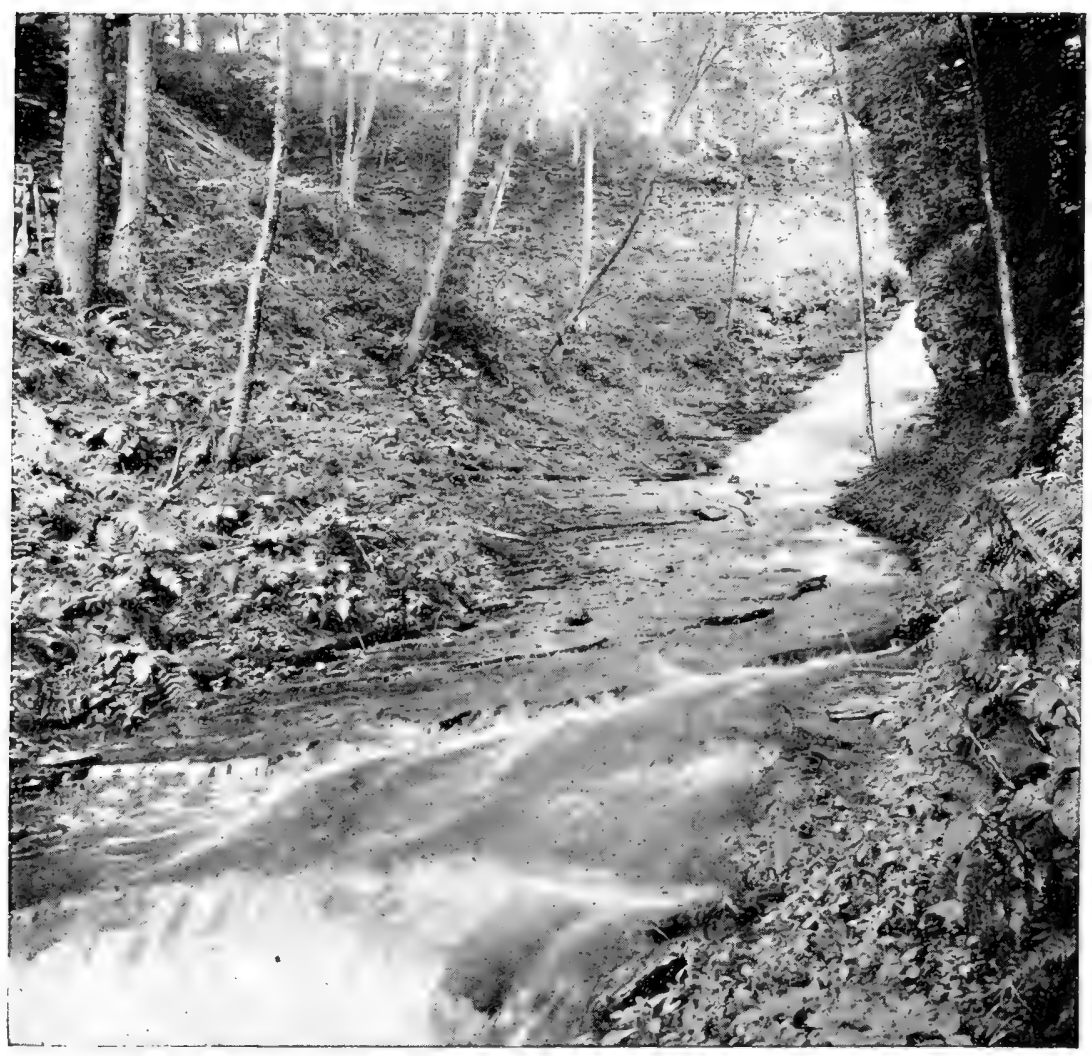

Entrance to the Little Ravine

I watched the ravine carefully, but for more than a week I saw no signs of the famous old leader. From the main ravine there was one narrow branch, with steep sides that ended abruptly. Here the hemlocks 


\section{$276 \quad$ Old White Wing}

were large, as were also a few basswoods which skirted its borders. It was getting late for the nesting of crows, and I had almost given up my search, when one day as I was sitting, well hidden from view, on the bank opposite this little ravine, watching a chipmunk at his spring house cleaning, I heard a low caw. I was all attention! A crow passed and entered the little ravine, and as it turned I caught a glimpse of white feathers. My energies were now renewed, and I determined to find the nest of this wary bird. I waited an hour, watching the entrance to the ravine, and was rewarded by seeing Old White Wing pass out.

I had no designs on the life of Old White Wing or his family. Not a single feather on this noble bird should come to harm, if I could protect him, and the knowledge of his secret nesting place would be as sacred to me as to him; but what I wanted to learn was the location of his nest and how he cared for his family.

The first thing that I must know was whether he had a definite route to and from the nest and when he was most likely to be at home. The next morning I prepared for an all-day's stay in the woods. I reached my hiding place without being discovered, and soon afterward saw Old White Wing fly down 


\section{Old White Wing}

the ravine. My observations for the day proved to me that he had a definite route, and that he remained away from home from an hour to an hour and a half. During this time I could explore the ravine and return to my hiding place without disturbing him. After three days of the most careful searching, I located a crow's nest in a thick cluster of hemlocks on the right bank far up the small ravine. It was well protected, and through my field-glass I saw a crow on the nest. I searched for a new hiding place which would give me a good view of the nest and, at the same time, not reveal my presence to the birds.

I found precisely what I wanted in an old basswood tree. Large ones are often hollow, being mere shells, the hollows sometimes extending up the tree for a distance of from ten to forty feet. A tree of this description stood on the bank of the ravine opposite the nest, and about one hundred and fifty feet from it. As the entrance to the hollow was on the side opposite the nest, I could approach from that direction without being seen by the birds. When I stood on the ground the underbrush at the foot of the tree prevented me from seeing into the nest, but, if I could erect a support ten feet high and bore a hole for inspection through the shell of the trunk, the problem would be solved, and I could watch what few people have had 


\section{8 \\ Old White Wing}

the privilege of seeing. After dark, with the help of a friend my support was constructed and placed in position, and a hole was cut through the trunk.

Nature never seemed more beautiful than on that May morning, as I prepared for my first day's study. A house wren was singing his morning praises from the old swect apple tree, and as I passed through the yard a mother hen was taking her brood for their first little walk; in the lane which led to the woods the bluebirds and robins were busy with their morning duties, and from over the meadows came the thump-thump-thump-rup-rup-rup-r-r-r-r-r of the ruffed grouse from Marble's Grove.

I was soon in my place of concealment in the basswood tree, and, with the aid of my glass, I could see the nest and its surroundings as clearly as though they were not more than twenty feet away. My position was not one of ease, for I was standing on a slat nailed across an upright. For five weary hours I watched and waited, but not a sign of Old White Wing! On the second day, when I was rewarded by seeing him make a visit to the nest, the tree could scarcely hold me! My legs ceased to ache, I forgot my weariness, for now I believed that I had found the home of Old White Wing.

The first real thing that I saw him do was to relieve 


\section{Old White Wing}

his mate. As my tree stood on higher ground, I could see into the nest, and there I counted five eggs. After an absence of about an hour and a half the female returned, preened and arranged her feathers, and took her place on the eggs. Many a time afterward I saw Old White Wing bring her food and in a score of ways show himself to be the most thoughtful of husbands.

By and by the five eggs hatched into five baby crows, and now began the serious business of the elder members of the family. This was the longlooked-for opportunity for the farmer, as at this time the parents are less wary of danger. I trembled for the fate of my crow family, lest Old White Wing, in his zealous foraging to fill the five hungry mouths in the tree top, might be killed, and his blood stained body hung in some cornfield to frighten away other crows.

As the young crows grew larger, the task of feeding them grew more and more arduous. From morn till eve both parents were kept busy, and the weary wing on which they returned told of the infinite labor necessary to feed a brood.

The young were soon large enough to begin their early education. Noisy little creatures they were by nature; so their first lesson must be-instant silence 
at the first hint of an approaching enemy. This they were taught by a warning caw from either parent. Before they were large enough to fly an accident befell the family. On the morning following a heavy wind and rain storm one of the young was found on the ground nearly dead. It was taken home and cared for, and soon we had a most famous pet, valued all the more because it was the offspring of Old White Wing.

When the young crows were large enough to stand on the edge of the nest, Old White Wing, on a branch not far away, would straighten up and gently flap his wings, and soon the young were imitating him. He would then hop to another branch, and then to one a little farther on, always using his wings. In two days the young could do the same, and in a week they flew to the clearing. But their fat little bodies were still covered with down. At night they roosted by their old nest; this, however, was soon abandoned, and they took to other trees like grown-up folks. They were probably taught to choose the long slender branches, and to keep a sharp lookout for hawks and owls; and thus, by the constant example of their parents, they were soon well educated in the habits and ways of crow life.

The different crow families were now meeting on 


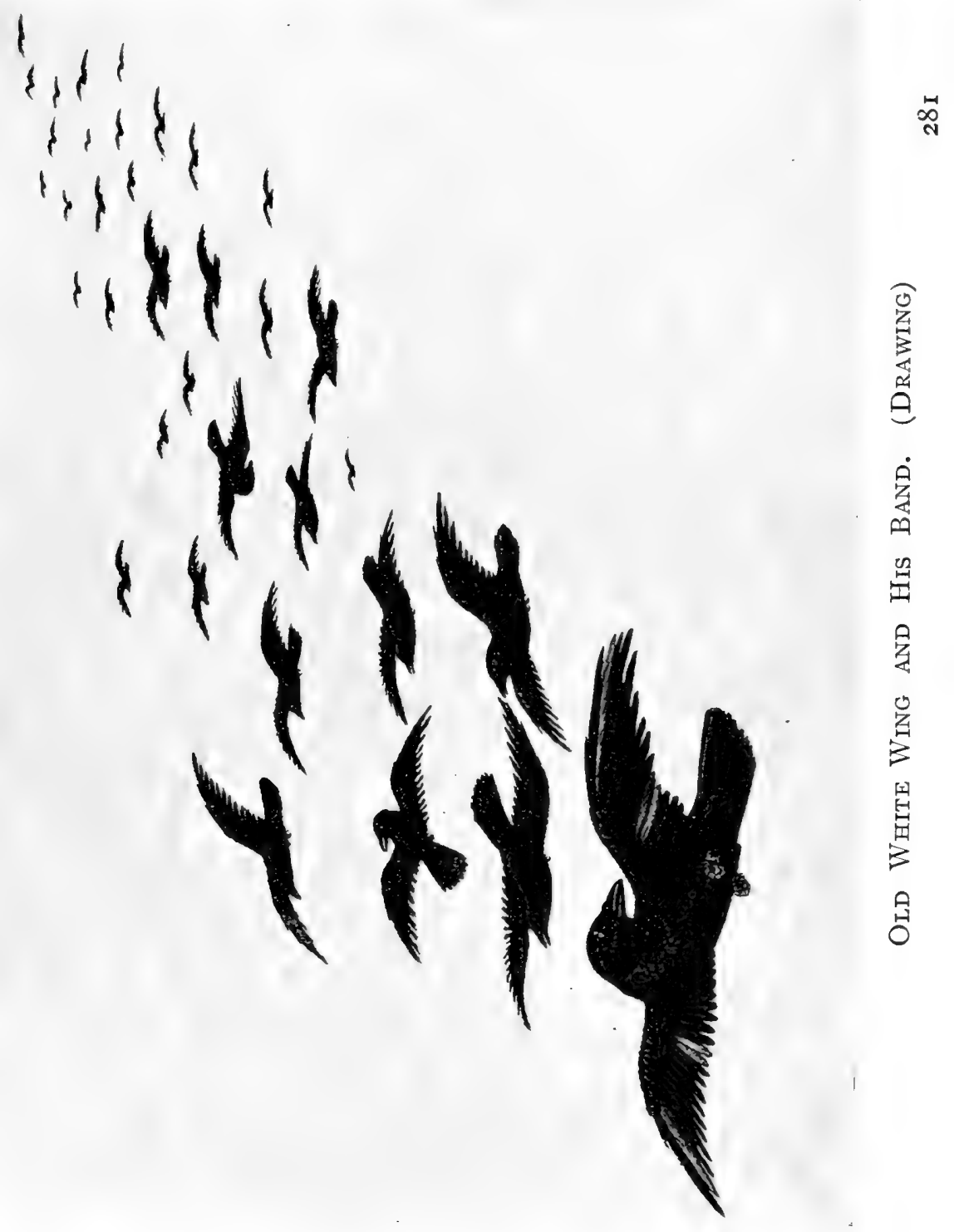




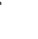




\section{Old White Wing $\quad 283$}

the newly mown meadows, and Old White Wing, as leader, had to resign his domestic duties for more public ones. Each day brought its varied experiences for the young. Some were well behaved, others unruly and headstrong, and the famous old leader had all he could do to get the young recruits under good command before cold weather. He succeeded admirably, however, for Old White Wing's colony was well organized and under discipline when he brought them to their roost in the hemlocks for the winter.

It is a well known fact that crows leave the roost in the morning, go to their feeding ground for the day, and return toward evening. Each band has a leader, and this season there had been greater care than ever on the part of Old White Wing to organize small bands with well trained captains. This seemed to predict a severe winter. He must have noted the thick corn husks, the wise muskrat, and the untiring labor of the squirrels.

There seemed to be greater hatred for the crows this year than ever before, and in the latter part of November Old White Wing and his band suffered from a midnight raid.

Winter came early and with deep snows. The crows visited their old feeding grounds, but scanty indeed was the fare they found. Some took to visiting 


\section{$284 \quad$ Old White Wing}

the haystacks and barnyards, much against the protest of Old White Wing. But what could he do against the gnawing pangs of hunger, when day by day he saw his loved ones starving? It would have been better had he and his band migrated far south to the Delaware.

But a yet greater peril awaited them! A demand for crows' wings had been steadily increasing, and all known schemes for the capture of these birds were being used. Old White Wing was constantly on the watch for danger, but his strength, too, was fast failing, and unless the snow and cold soon broke, spring would come too late to relieve his distress, even if he escaped snare and gun.

For three days a storm had been raging and the crows were unable to leave their roost. The morning of the fourth day broke clear and crisp and cold, and the birds started on weary wing in search of food. Not far from the hemlocks in an open meadow stood a small barn, directly in the line of one band of crows as they left for their feeding ground-the band in command of Old White Wing. As they neared the barn, the hindmost ones were aware that something unusual was taking place in the front ranks. The cause was not far to seek; for near the barn, on the snow, lay the carcass of a calf. Old 




Death of "Old White Wing." (Drawing) 



\section{Old White Wing}

White Wing rose high in the air and gave a warning caw. The others at first obeyed and scattered, but the temptation was too great, and in a short time a dozen crows were feeding. Others followed, and soon Old White Wing himself was among them, his sense of danger being, for the moment, overpowered by the pangs of hunger.

Two sharp reports and the air was full of shot! A third and fourth followed for those birds which had taken wing. Then all grew still.

The little side door of the barn opened and two men appeared. There was a look of satisfaction on their faces as they gloated over the fifteen birds killed and wounded. Some of the latter had broken wings and legs, and were going off over the snow in different directions, even in this hour of peril obeying the teachings of their great leader and making a last heroic struggle for their lives. They were soon overtaken, however, and a blow on the head from a stick ended their efforts.

Among the wounded was Old White Wing. With renewed energy he attempted to escape, but, alas! the one who had saved so many lives was now powerless to save his own. A well directed blow left without a leader the flock he had guarded and cared for so long. 
A crow was just a crow to these men, and when the price of two pairs of wings was offered for the one with the white feathers, they counted themselves fortunate.

When spring came and the separation for the summer homes took place there was only a fragment of the host which in the autumn had made the grove vibrate with their cawing. Since the death of Old White Wing no such leader has ever appeared, and the old roost in the hemlocks has been largely forsaken. 


\section{THE GREAT HORNED OWL}

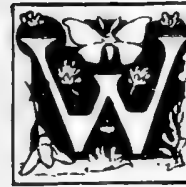

ORK had been going on all day in the sugar bush; the sap had been gathered and drawn to the boiling place, until there remained to be visited only a few scattering trees near the swamp. As it falls to the lot of the boy on the farm to run errands and do odd jobs, so the collecting of the sap from these few trees naturally fell to him, and before he was out of hearing a voice from the sugar camp called to him, "Don't be gone long, for it will soon be chore time."

The shadows were growing long as the old horse moved the sled slowly along the snowy road winding in and out among the tall maples, and gloom was settling in the thick hemlocks at the base of Hall's Hill. The boy was softly whistling to himself and thinking as only boys can think, when a rabbit with easy graceful bounds crossed the road but a few paces ahead of him, stopping by the side of a birch bush to nibble the tender buds. Just then a sound came up from the swamp which startled the boy, not 
because it was unfamiliar to his ears, but because, when he was younger, he had been told if he was

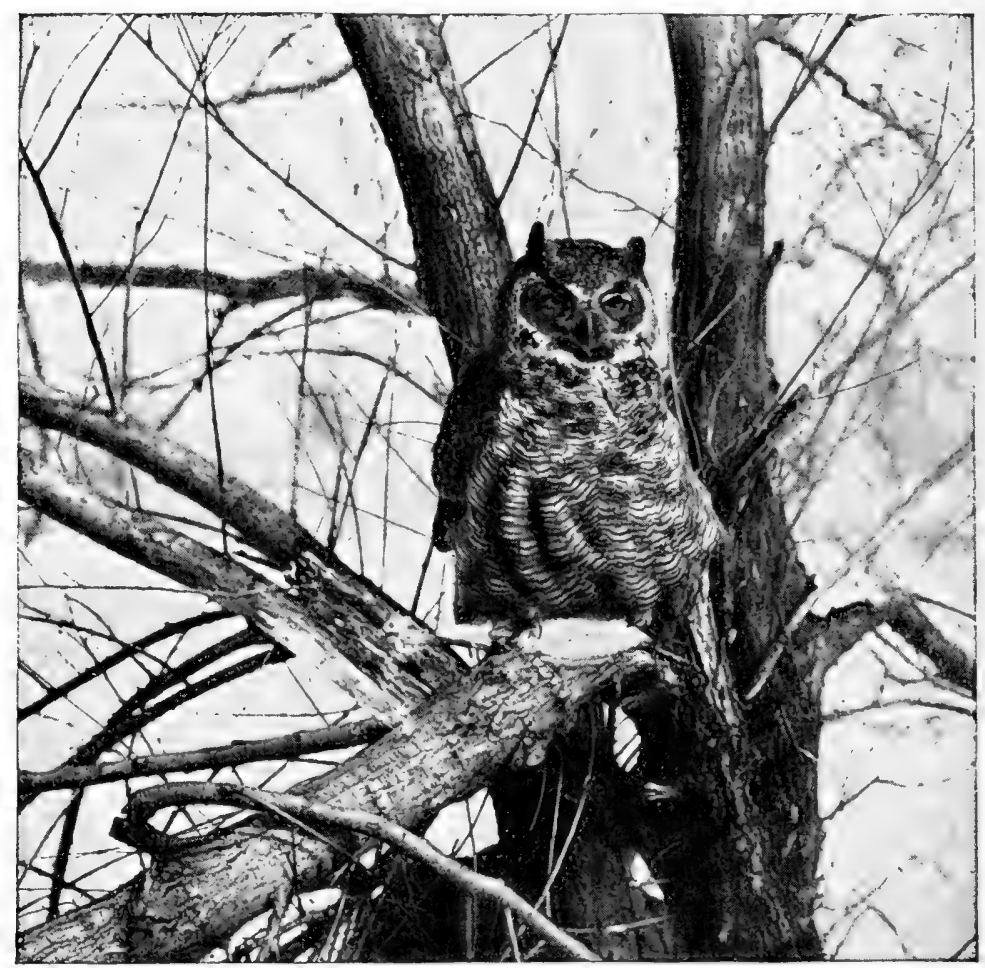

The Great Horned Owl

not a good boy the great owl from the swamp would carry him off some night.

Why did the rabbit pause in his dainty meal, squatting in his tracks, until his form more nearly resembled a footprint in the snow than a living mammal? Did he too know this call from any experience of his own? The chattering red squirrel dropped 


\section{The Great Horned Owl}

into the crotch of a tree, ceasing to be curious about those passing below, as the ominous and almost supernatural "Whoo-hoo-hoo-wohoo-o," sounded through the dismal swamp and echoed through the maple grove. This was the hunting call of the Great Horned Owl.

The actions of the rabbit and squirrel fully confirmed the many stories concerning this bird in its relation to the smaller mammals. The boy had always heard that this owl was a veritable Nero among the feathered race. He had seen the feathers from the ruffed grouse on the snow among the low hemlocks, with not even a track left behind to give a clue to the little tragedy enacted in the silent forest; he remembered, also, about the disappearance the fall before of some chickens from a tree close by the barn, and later one of the bodies being found on a high fence post with the head eaten away. While these thoughts were passing through his mind the boy was nearing the swamp, when his reverie was again broken by the dismal hoot of the owl. Already he knew a great deal about the shy wood folk, whether in fur or feathers, but as yet he had never discovered the nest of the Great Horned Owl. It was now the first week in March, and of late he had frequently heard the weird call from the swamp, causing him 
to believe the birds were nesting there, and he fully determined to make a search at his earliest opportunity.

This opportunity came sooner than he expected, for the next morning it had turned cold and a light snow had fallen. As there would be no sap to gather, the boy was given a holiday after his usual morning duties were done, and he immediately set out for the swamp, hoping before night to locate the nest. It might seem an easy task to find such a large nest, but the swamp contained several acres, and in many places the evergreens were so thick as almost to exclude the sunlight.

The day was spent in a fruitless search, which perplexed the boy, who had often located the nest of the bobolink and the meadow lark, nests that are not by any means easily found. However, as the search had been systematic and the whole ground had not yet been covered, he still hoped to find it before the eggs had hatched, for he wished to become familiar with the nest and eggs, as well as with the young and old birds.

The second day's search ended about noon in rather an interesting manner. The boy stopped for lunch under a hemlock that he knew well, for the spring before a pair of crows had had a nest in 


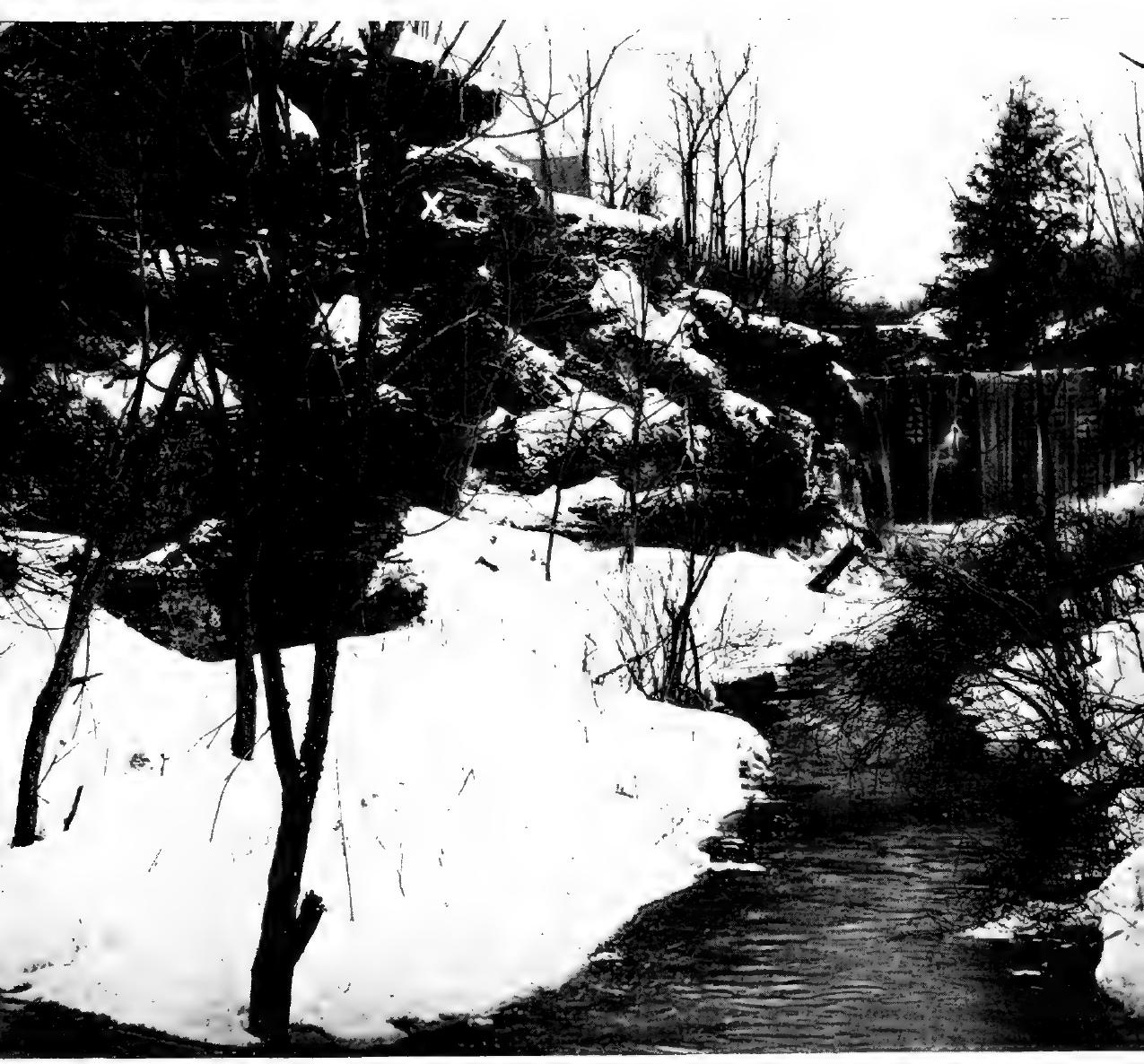

An Unusual Nesting-Place of the Great Horned Owl (Location indicated by $\mathrm{X}$ ) 


\section{The Great Horned Owl}

the tree. The old nest was still there, and, just to see in what condition it had been left after the storms of winter, he climbed the tree. The nest was between fifty and sixty feet from the ground. Just imagine the boy's surprise, when about thirty feet from the nest, to see a Great Horned Owl silently glide off and wing its way through the tree tops. It was a revelation, upon reaching it, to find that a Great Horned Owl had really used an old crow's nest, which had the appearance of being slightly remodelled and was sparsely lined with evergreen leaves and feathers. In the nest were three white eggs, nearly globular in shape and about the size of a bantam's. The boy afterward learned that the usual number of eggs deposited by the Great Horned Owl is two, and that the bird sometimes constructs for itself a nest in a hol'ow tree or an evergreen.

It was impossible to tell how long the bird had been sitting, but as the period of incubation is about four weeks, this fact could be approximately determined when the eggs hatched. On the first day of April there were two little owls in the nest, and a day later a third appeared. They were queer looking little birds seeming to be nearly all head and eyes, and their bodies were covered with the softest of down. 


\section{The Great Horned Owl}

The young birds grew very slowly, although the remains of fish, mice, squirrels, rabbits, and birds of various kinds furnished abundant evidence that the old birds were lavish in supplying them with food. They remained in the nest for about eleven weeks-a long time in comparison with most of our birds, many young birds leaving the nest in from twelve to fifteen days, and the woodcock, bob white, and ruffed grouse in about as many hours.

During all this time the boy saw very little of the parent birds, which was a great disappointment; but from the few glimpses which he succeeded in getting he learned several interesting things. He had always been told that owls could not see in the daytime. One day he approached the nesting tree very cautiously, but the old bird on the nest evidently saw him, for it immediately flew into a small cluster of hemlocks some little distance away. Again the boy tried to approach the bird, but with little better success; finally, however, he succeeded in getting close enough to see the owl walk back and forth on a limb, ruffling its feathers very much after the fashion of a strutting turkey cock. This was probably from anger rather than anything else. The bird soon flew, and this time it went so far into the thick hemlocks as to be lost to view. This and other similar circumstances 


\section{The Great Horned Owl}

convinced the boy that the Great Horned Owl is not lacking in good eyesight in the daytime.

Everything progressed nicely with the owl family, but the boy desired very much to know the hunting methods of these powerful birds and how they located their quarry. In an open part of the swamp, not far from the nest, stood a solitary old stub, some eighty feet in height, and holding aloft, from its barkless and whitened trunk, a solitary branch. The position of this former monarch of the forest commanded a good view over the trout stream on the one side, and on the other, over a small pond which contained numerous forms of animal life. The boy was well acquainted with the old stub, knowing its possibilities both as a home and a watch tower for the feathered tribe. Within its walls the flicker and the hairy woodpecker had drilled, and nested; here also in winter the screech owl found a shelter from the fierce storms that swept over the swamp; from its branch in summer the rattle of the belted kingfisher could be heard; and perched on the summit of the broken shaft the "hen hawk" would locate a mouse in the grass, or, perchance, a sleepy old frog at the water's edge.

The sun had already set at the close of a beautiful spring day, when the boy found himself a little distance above the old stub, on the trout 


\section{The Great Horned Owl}

brook, stringing the last speckled beauty, preparatory to going home. Suddenly the stillness was broken by an ominous cry reverberating through the forest, and echoing and re-echoing from the neighboring hills. As it sounded across the pasture, it seemed to vibrate the gathering gloom. The boy stood motionless, listening intently, for he knew it to be the hunting call of the Great Horned Owl. "He will soon be at the old stub watch tower," said the boy to himself, "and I will catch him in the act."

Cautiously he approached and surveyed the old stub, as it stood silhouetted against the sky, above the adjacent tree tops, but not a sign of an owl was to be seen. Quietly he concealed himself, waiting and watching, and listening for the different woodfolk that might be astir. Near by he heard the twitter of an uneasy bird, the squeak of a mouse, the scurry of fast-flying feet on the dead leaves, and the splash of the muskrats playing in a pool of the creek. These sounds were ever sweet music in the ear of the country lad, but his thoughts that night were of the Great Horned Owl and his hunting. A red squirrel, discovering him, came upon a branch overhead, chattering and scolding as usual, and for an instant the boy turned his gaze upon him and then back again to the stub. During that brief moment, as silent as 


\section{The Great Horned Owl}

though borne on the wings of the night, a something had added a foot or more to the height of the old stub, slightly changing its outline, although it seemed as stark and silent as before.

As the darkness deepened, the sounds from the wood folk grew more numerous, but ears accustomed to them gave little heed. "Whoo, hoo-hoowh-o-o," sounded again, so close this time as to startle even the watcher of the old stub. To the boy the swamp seemed suddenly to become as silent as the grave,-save for the distant, hoarse quawk of the night heron. But to the delicate ears of the listening owl there was a hurried movement, a tcll-tale sound, and before the echoes of that terrible call had died away, what appeared to be a part of the stub had taken wing and silently swept into the ta!l grass by a clump of bushes. The owl emerged a few moments later with what appeared to be a rabbit in its talons and winged its way towards its nest.

For an hour the boy watched and waited, but not again that night did he see the owl or hear his call. However, he was satisfied, for he had seen the Great Horned Owl at his hunting.

After the young owls left the nest, the hunting call was less frequently heard, but again in the autumn, and occasionally through the winter, it sounded from 


\section{The Great Horned Owl}

the swamp. For years the owls nested there, obtaining their food from the wild life about them, but sometimes feasting upon a chicken or young turkey from the surrounding farms.

During these years, whenever an opportunity presented itself, the boy studied the animals about him. He tramped and trapped as the seasons changed, never seeming to grow weary of his chosen pastime; and although he did not know it, he was changing, the savage within him giving place to the humane. He passed through the usual stages of trap and gun, made various collections of nests, eggs, and mounted specimens, but finally dropped all for the one harmless instrument-the camera.

After years of work and dozens of negatives had been made of wild birds and mammals in their native haunts, he still had none of the Great Horned Owl. This was due to the nocturnal habits of the bird and to its natural shyness. You may tramp the woods for many a day and not even see a Great Horned Owl, much less produce a photograph of one. But patience is usually rewarded, and that sometimes in a most unexpected way.

The Great Horned Owl, when it once forms the habit of visiting a certain farm building for the purpose of carrying off poultry, becomes very bold and 
. $\quad \cdot=$ 
daring. The same is true of some of our hawks which have been known to fly within a few feet of a man and pounce upon and carry off a chicken. Owls usually make such visits by night, but occasionally during the winter, when food is scarce, they get into the habit of visiting the farmyard in the daytime. Immediately upon the capture of the fowl, the owl retreats to the woods, but, the load being heavy, the bird sometimes stops to rest upon the broad rail of a fence, or upon a log, or even upon the ground. At such times the owl plainly shows its nature by holding to the fowl, even when followed. When such stops are made, with a little careful manœuvring, the owl may be approached near enough to be photographed. From early experience it was learned that a man on horseback could ride under a tree where there was a crow or a hawk without disturbing the bird; so, too, the great horned owl has its weak point, it may be fascinated by a dog.

The photographing of the Great Horned Owl under the following conditions is not difficult: wait until the owl seizes the fowl and stops to rest on the return to the woods, then let a dog be led to within twenty or thirty feet of the owl, and the bird will be all attention for the dog, taking apparently no notice of the person leading it. The behavior of the owl at such 


\section{The Great Horned Owl}

times is very amusing; it stands motionless, gazing intently at the dog, but after a few minutes, if the dog remains quiet, the bird seems to become nervous, stepping first to one side and then to the other, hissing, snapping its beak, and ruffling its feathers. After this the owl will usually try to make off with its prey; but if another halt is made, it acts in much the same way as at first, excepting that it is still more nervous. While the owl's attention is thus attracted to the dog is the time to approach within "photo distance" to get the "snapshots." 


\section{THE SCREECH OWL}

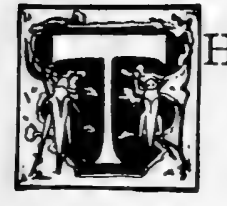

HE screech owl is found throughout the whole of the United States and the southern part of Canada. It is one of the smaller owls, being about eight inches in length, with conspicuous ear tufts; its wings and tail are barred and its legs feathered. The adult bird may be gray or brownish red. This variation in color, or dichromatism as it is called, is well marked, and for a long time it was supposed to have something to do with the sex or age of the bird, some scientists even going so far as to class the two as different species. In reality it has to do with none of these, although just why it occurs has not been satisfactorily answered. This dichromatism occurs very frequently among the squirrels, and it is not uncommon in the insect world.

The screech owl is one of our most beneficial owls, for it feeds principally upon mice, reptiles, and insects, but sometimes-upon small birds. The greatest good is done in the destruction of field-mice, which do so much damage to the grass roots, to the grain both when stacked and in the shock, and to young fruit- 


\section{$306 \quad$ The Screech Owl}

trees. The greatest damage to trees occurs in that part of the owl's range where the snow is so deep that it is impossible for the bird to reach the mice.

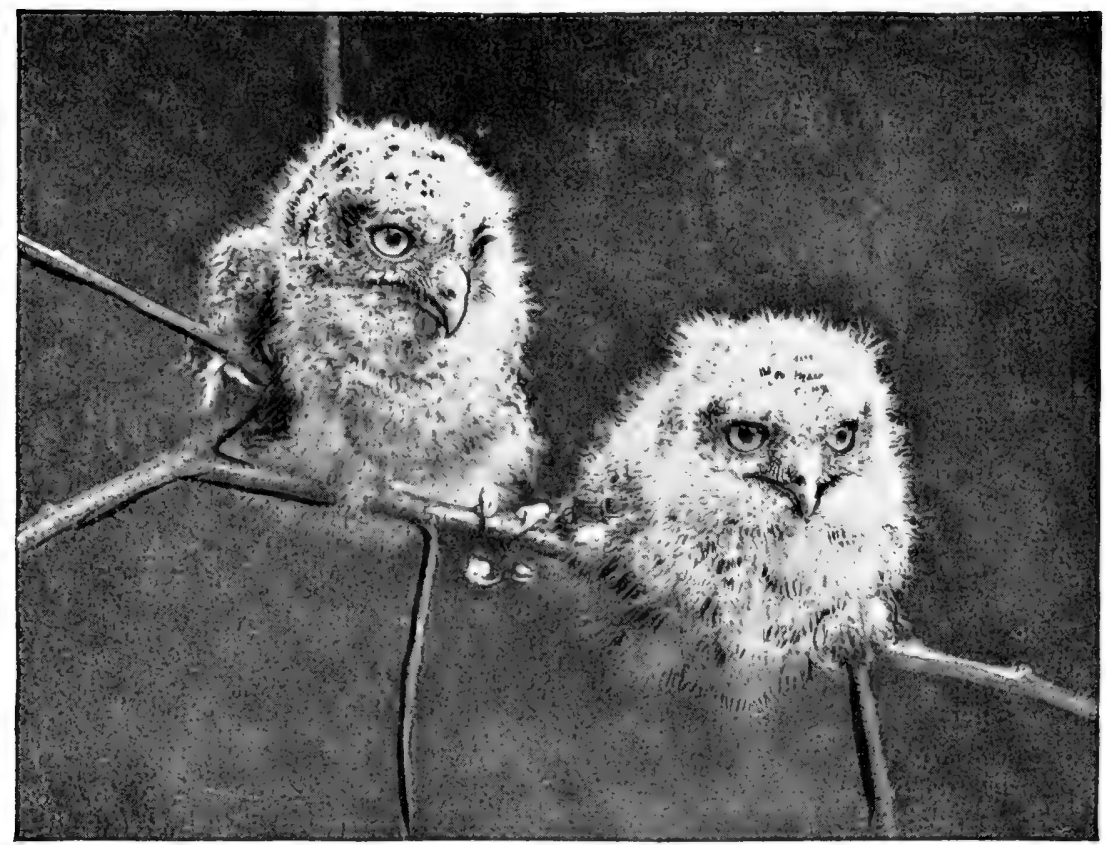

Young ScReech Owls.

To the field student of natural history there are no tracks in the snow more common than those of the short-tailed field mouse. They are particularly plentiful about hedgerows, brush heaps, stone piles, hay and grain stacks, and farm buildings, while the orchard is one complete network of them. Sometimes in the morning one may read on the soft snow a chapter from Nature, written in her own 


\section{The Screech Owl}

hand and better than anything ever found in books. Let us study it together. The old orchard is before us; many of the trees have long since passed their commercial usefulness, but they should be spared, for they are now the homes of our animal friends. Time and the elements have dealt harshly with them, and the boisterous wind has torn many a limb asunder; here, for many years, the flickers have drilled their homes, and the cavities in the old trees have grown larger year by year. Toward one old tree, one-half of which is tipped over until it touches the ground, many mice tracks converge,-probably the seeds in the apples beneath the snow are the attraction, or perhaps some other dainty well liked by the mouse. We notice that here a well defined track suddenly ends, and we wonder where the mouse could have gone; but if we look a little closer, we find, at the end of the trail on either side, a slight mark in the snow. These marks were probably made by the wing-tips of some night flying bird, in whose deadly grip the little mouse met its end. We now examine some of the cavities in the old trees, from one of which we draw forth a plump, sleek screech owl. Could he but talk, he would without doubt be able to explain those marks in the snow, and to tell the reason why the mouse would never again scamper about in the 


\section{8 \\ The Screech Owl}

moonlight, leaving behind him dainty footprints in the snow.

Since the screech owl is of such great economic value, its presence in the agricultural districts should be encouraged. It is not, like many other birds, beneficial in one part of its range and harmful in another; but in doing so much good the screech owl sometimes does a little harm, for it occasionally kills small birds, and has been known to attack a ruffed grouse or hen, though no serious harm came to either. However, this bird catching propensity of the owl is very much in its favor at present, for it has developed a liking for the English sparrow, and is frequently to be seen about ivy covered buildings and other favorite roosting places of the sparrows. This good report of the screech owl seems to be common in other states besides New Jersey and New York. From Mount Perry, Ohio, Mr. R. S. Russell writes as follows:

"Last summer the English sparrows were so thick around my house as almost to set me wild, when a little screech owl got to visiting us every night and at each visit he carried off a sparrow. My house is thickly covered with vines, and the little owl would make a dash into the vines and capture his sparrow every time. By fall they were well thinned out."

The screech owl breeds throughout its range, gen- 


\section{The Screech Owl}

erally in hollow trees, but not in the deep woods. Little nesting material, other than rotten wood and a few feathers, is used. The eggs, varying in number from four to six, are white and nearly round, and in our latitudes are usually deposited from the fifth to the twentieth of April.

The young, if taken a few days before they are ready to leave the nest, may be tamed quite easily.

In the latter part of June, IgO4, I was informed that a coachman had caught two little owls while they were lazily dozing the morning hours away on the top of a woodpile. I called upon the man, and was informed that he had two owls, which he called "cat-owls." They were in a box by the barn, and he told me that three times a day they were fed bread soaked in milk. The larger owl, he informed me, was a male and the smaller one a female. I do not know how he determined this, but he was very positive in his statements concerning owls, telling me a great deal about these birds: that they were very scarce; that if, when about to sct out on a journey an owl "hooted," you were sure to have bad luck; also that if for three nights in succession an owl was heard close to a house and from the same tree, there would be a death in the family within the next six months. To all this astonishing information he added that he 
could take these birds to a man in Orange who would pay at least six or eight dollars for them.

I pitied the little birds-they were screech owls-and offered the man what I considered to be a moder. ate sum for them. He accepted the offer very quickly, although it was considerably less than he had said he could get for them in Orange.

I carried them home in a paper box, and arranged temporary quarters for them, until I could construct something better. I gave each of them an English sparrow, which I fancied was more to their liking than bread and milk; nor did they need to be urged to eat, but eagerly began their feast at once.

We gave them appropriate names, corresponding to sex as indicated by their former owner, calling the larger one "Billy" and the smaller one "Betty." They were rather large to thoroughly tame, but I handled them quite a little, and soon Betty appeared to enjoy it and became very friendly, but Billy would sometimes protest strongly with a hissing noise, similar to the prolonged sound of the letter $a$ in care, accompanied by a snapping of his beak. Betty became so tame that my little daughter could scratch the owl's head, and it would have been difficult to tell from the appearance which one enjoyed it the more. 



\section{The Screech Owl}

The little owls soon came to know my voice. When I called his name, Billy in particular would give me his peculiar cry of $a$, even before I was in sight. If he failed to answer, I always tried to get him to 'speak' before I would give him his portion of food. It was evident that this sound expressed with him more than one thing, and it seemed to me to be differently accented on different occasions. I did not think at the time that this training would serve in any particular way, except that it would probably strengthen certain points that have to do with animal intelligence. Upon arriving home one day, however, I was told that Billy and Betty had escaped, and that, although the basement had been thoroughly searched, neither could be found. I myself searched the basement again, but with no better success. Finally I called "Billy, Billy," and listened. Billy promptly responded by giving the sound of $a$, and, guided by the sense of hearing, I found him sitting on the gas pipe close by a joist, with Betty beside him.

The next morning I put a basin of water into a box, and in a short time Billy was taking a bath, and when he had completed it, he was the wettest bird that I ever saw; even the feathers on the top of his head were wet. After this Billy took a bath very often, but Betty less often. 


\section{I 4 \\ The Screech Owl}

I placed them in bushes several times, just to see what they would do. Both of them could fly well, but they did not seem to think of it when out-of-doors. When all was quiet they would remain motionless; startle one, however, and it would open its eyes wide, but if the light was bright the bird would quickly bring the lids close together, forming a mere slit, thus shutting out most of the light, and probably by this means giving it a far clearer image of me. Again being left alone for some time, it would arrange its feathers and become as motionless as before, keeping always the ear-tufts slightly raised. But if I gradually approached, it would slowly rise to its full height, at the same time elevating the ear tufts. Standing in this position it resembled more nearly an old stub on the limb than a bird.

At last the owl-house was completed and placed in a cherry tree in the garden. Late in the afternoon the owls were put in it-free at last and with a home besides. The next morning both were there; but whether they had been out during the night I could not say. The second morning Billy was gone, and although I looked about I failed to find his hidingplace. In the afternoon I was working in the garden, and an old robin, that had a nest in the next yard, was making a great disturbance. I could see no 


\section{The Screech Owl}

cat or other cause for this outcry, and the young robins were not large enough to leave the nest. I stood it until my curiosity got the better of me, and

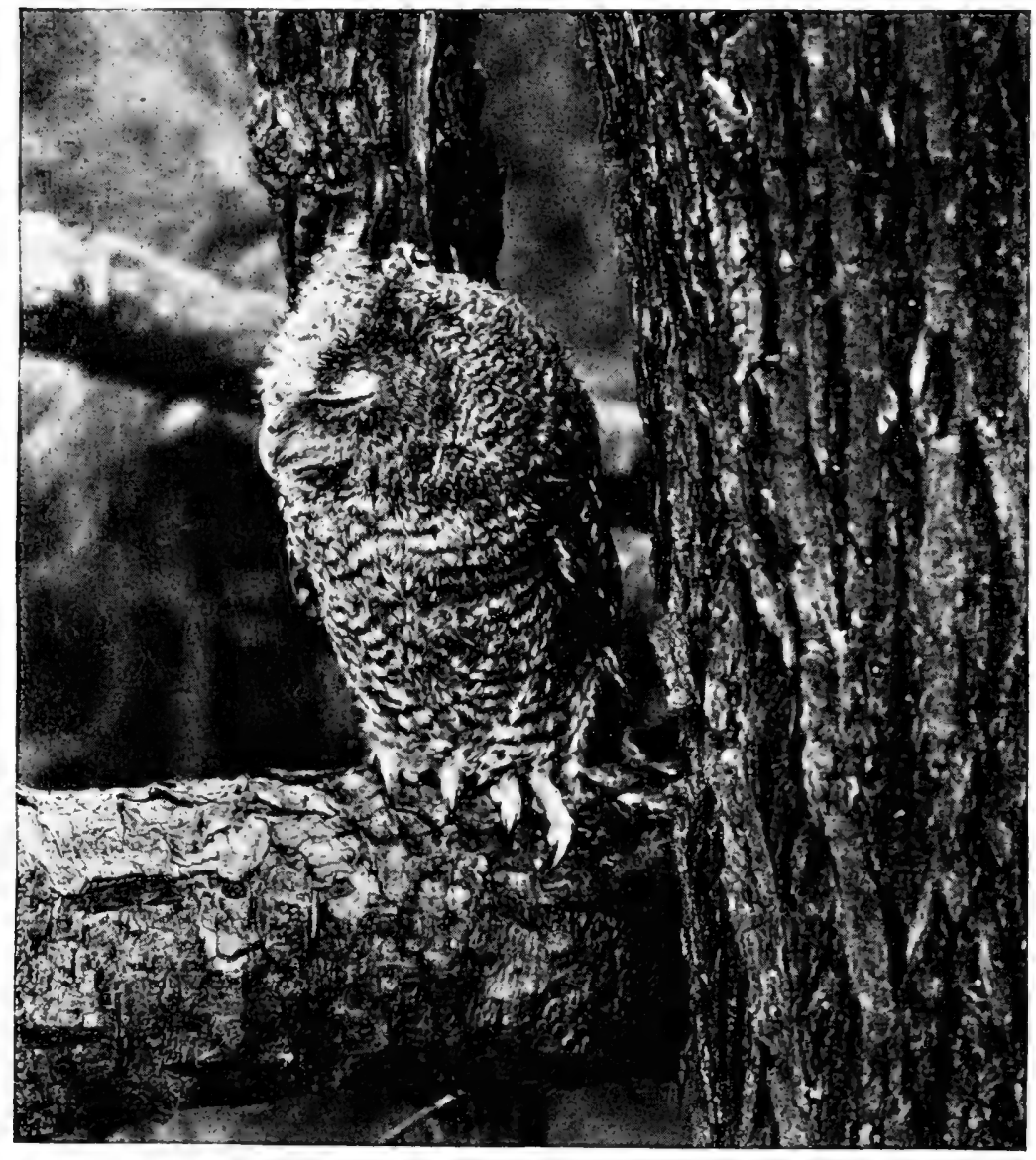

Billy Wondering What the Fuss was About

then set out to find the cause of all this alarm. By this time the male robin had arrived, and he too was greatly distresssed. A bluebird that chanced to be near had joined in, and then it dawned upon me that 


\section{The Screech Owl}

it might be the sight of Billy that was causing this uneasiness among the birds. Sure enough, in a snug retreat formed by some branches sat Billy, with his eyelids slightly open, trying to discover what all this fuss was about. I returned him to his home, and for the next two weeks he was to be found there nearly every day, Betty, however, was the more regular of the two. The owls never seemed to be hungry, but this I accounted for by the fact that in the next yard there were several evergreens, where English sparrows roosted and nested in considerable numbers.

Vacation time came and passed, and when I returned, Billy was not in, but Betty was at home and had grown both in stature and in beauty during my absence. It seemed to me that the sparrows had greatly diminished in number, much to my joy. In a few days Billy returned, and he too had grown to be a beauty.

During the autumn and early winter they were to be found the greater part of the time in their snug house in the cherry tree, but occasionally one or both would be absent for two or three days at a time. It is now the first of February 1905, and the little owls are still "at home." I hope that they are rightly named, "Billy" and "Betty," and that when spring arrives they will decide to nest in their present abode. 


\section{THE “HEN HAWK" AND HOW IT WAS PHOTOGRAPHED}
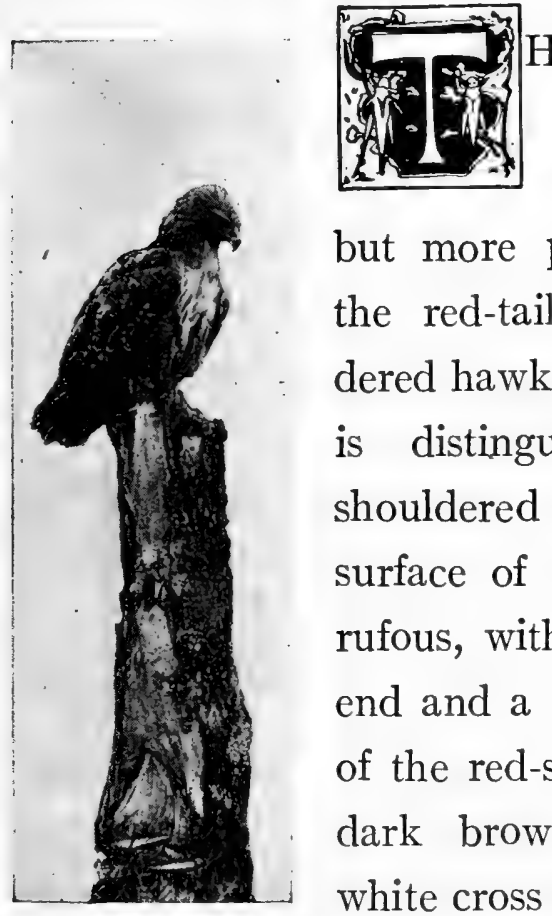

HE term "hen hawk" is a very loose one and includes several hawks, but more particularly it refers to the red-tailed and the red-shouldered hawks. The red-tailed hawk is distinguished from the redshouldered by having the upper surface of the tail a rusty red, or rufous, with a black band near its end and a white tip, while the tail of the red-shouldered hawk is very dark brown or black with five white cross bars; also, the shoulder of the latter is a rich rufous.

The red-tailed hawk is a very magnificent specimen of its family. It is one of our most common hawks, doing little harm usually, for it feeds principally upon small mammals, reptiles, and insects. I cannot agree 


\section{I 8 The "Hen Hawk"}

with those who pronounce it a "notorious visitor" to farmyards; at least this has not been my observation. It is very frequently seen about pastures and meadows, hunting for its favorite food, the field mouse. During the late summer and autumn it is often observed circling high in the air and whistling "Kee-e-e, kee-e-e," for hours at a time. For this harmless amusement, and for being so frequently observed, it is condemned by farmers and poultrymen for the depredations of the less seen and more sly hawks. Usually much of the blame should fall at the door of Cooper's hawk, the sharp-shinned hawk, or the American goshawk-these being the real "hen hawks."

For the one act alone of destroying field mice the red-tailed hawk should be granted protection of the strictest kind, and agriculturists should be the first to insure it. There seems to be in the minds of many an idea that to let a hawk or an owl escape is doing a great injustice to mankind in general.

It is said that the red-tailed hawks are quite tame in the West, and that a man can approach within a short distance of one; but generally speaking, they are very shy in the East, this wildness being probably due to their being so much persecuted for their supposed poultry stealing habits. 


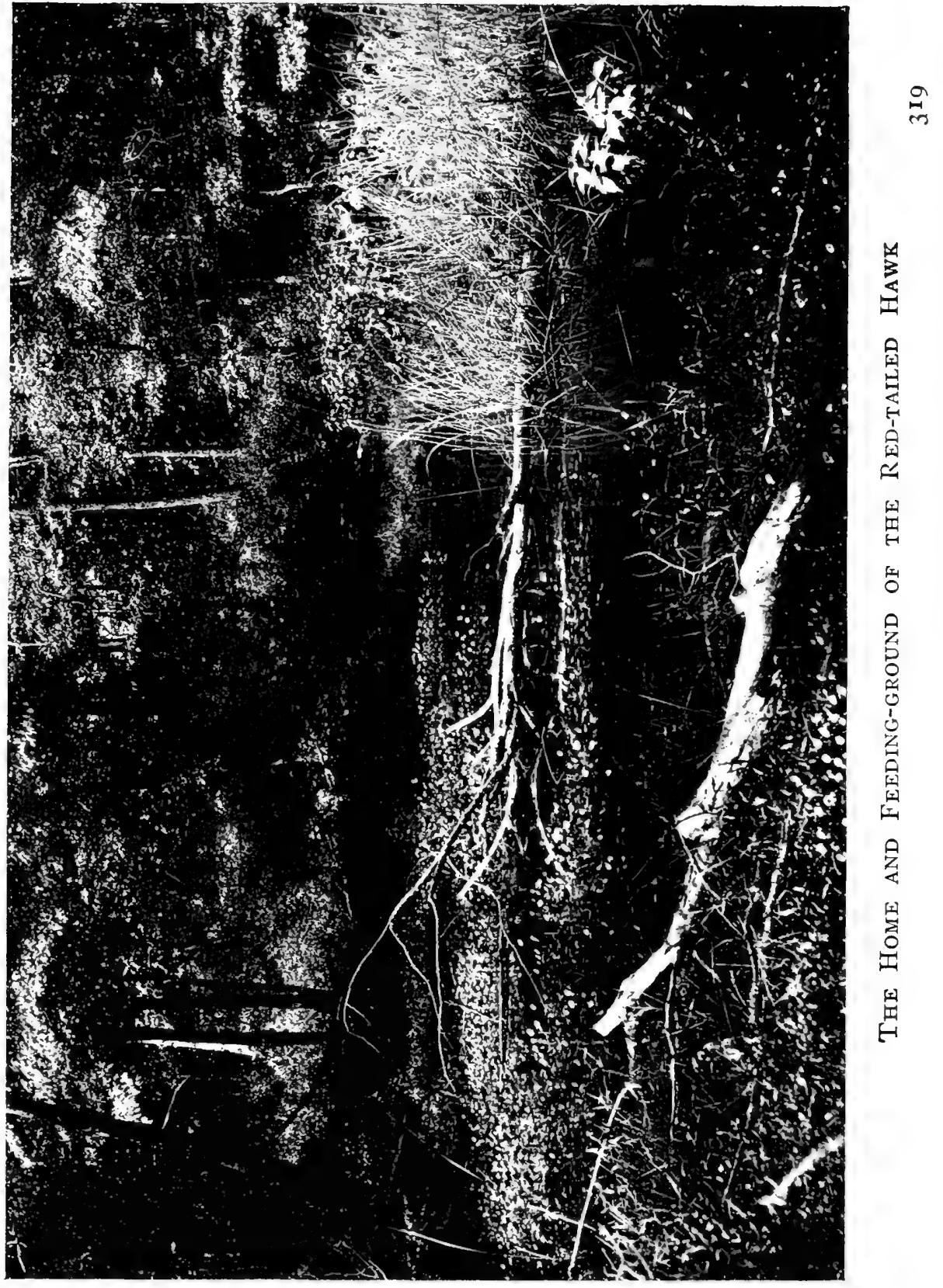



The nest of this hawk is to be found in high trees in the deep woods; it is a bulky affair, but quite shallow, being composed of sticks and roots often a foot or more in length, with a good mixture of coarse grass, while the inside has a sparse lining of moss and a few feathers.

One August day, as I was tramping through a marshy place in a piece of woods, I accidentally surprised a red-tailed hawk which was probably hunting for frogs or other food. Only a few days before, I had seen a hawk of this species within a short distance of where I surprised this one. On the day that I saw the second hawk, in a clearing on the edge of the swamp, I came upon a boy setting some traps by a stump, and scattering about them the waste parts of a fowl and also of a woodchuck. I was interested to know what was his object in doing this, and he told me that skunks from the neighboring woods were troubling his chickens.

I inquired of him if he had seen any hawks about, and why he believed that it was skunks and not hawks which had caught his chickens. He answered me by saying that as they were taken only at night, it could not be the work of hawks, although they were plentiful in the swamp.

From what I had seen of the hawks in this vicinity, 


\section{2 \\ The "Hen Hawk"}

and having good reasons for believing that some young had been reared there in the spring, this bountiful supply of bait suggested to me an idea. I had seen, but a few days before, a whole family of redtails about a woodchuck that had been shot and left by its burrow. It is seldom that the old hawks feed upon carrion, but many times they will come and sit close by if there are convenient perches for them. The young may be tempted to eat of it, for they are not yet skilled in hunting and cannot catch their prey so readily as can the older and more experienced hawks. It is the young that sometimes come to the poultry yard, for they can catch a chicken more easily than they can catch a mouse.

I inquired of the boy if he would be busy for the next few days, and being answered in the negative, I employed him to do a little bird watching for me.

Near the stump where he was setting the traps lay a small tree, one end of which we placed upon the stump, while the other rested upon the ground. Just in the rear was the swamp where the hawks had been seen. The duty of the boy was to rise early in the morning and, from a secluded spot, watch the tree that we had placed upon the stump. The first morning he saw nothing, but the second he saw two of the birds perched upon the tree, with 
5:

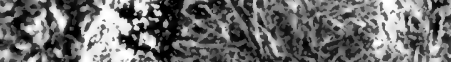

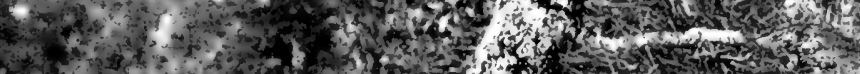

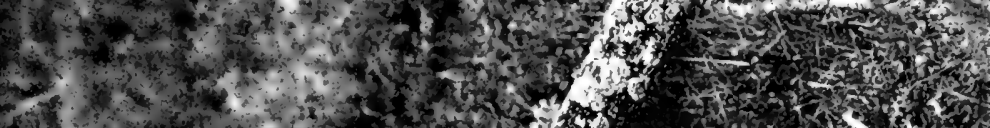

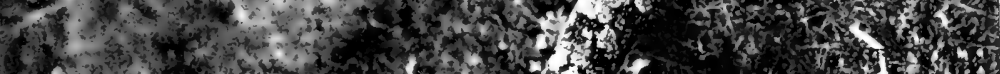
3 (1)

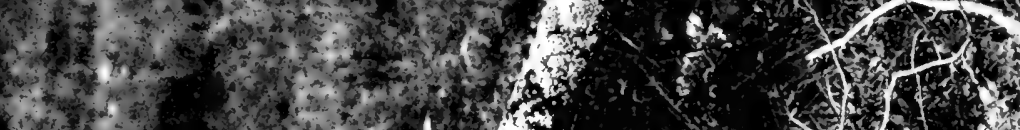

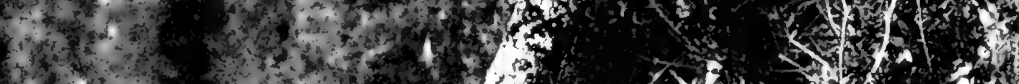
1.5. (1)

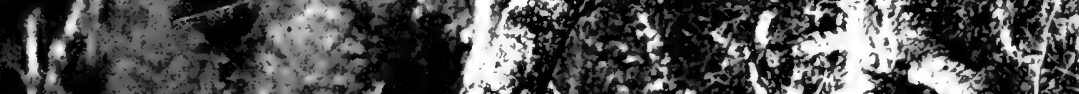

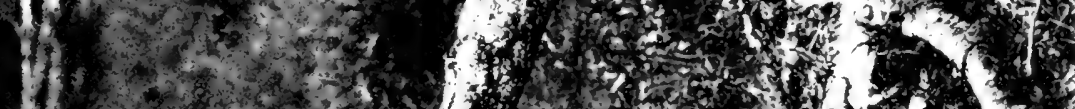

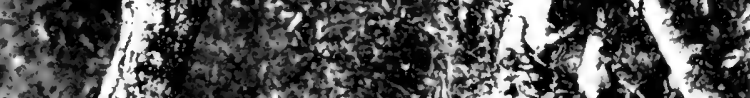

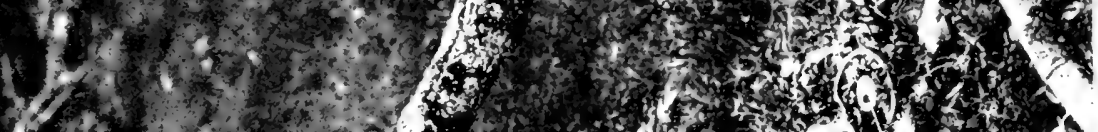

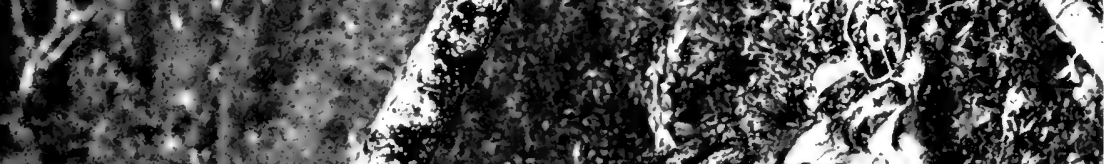

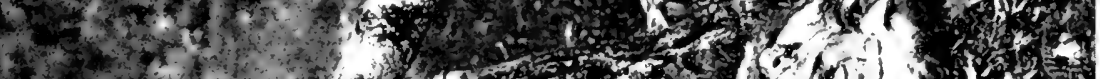
(1)

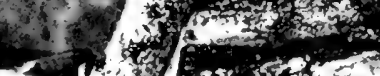

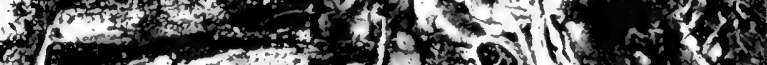

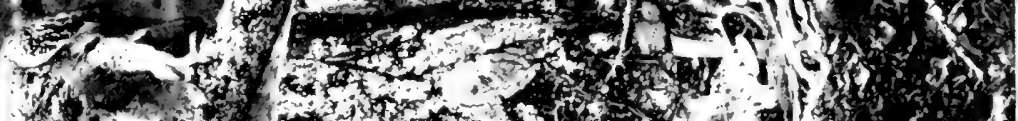
(2) (1)

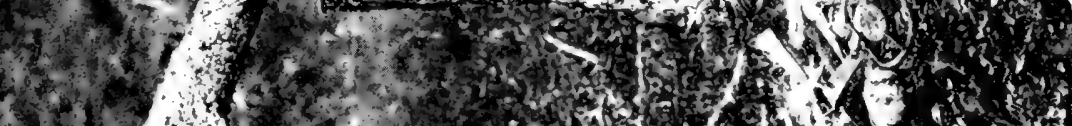

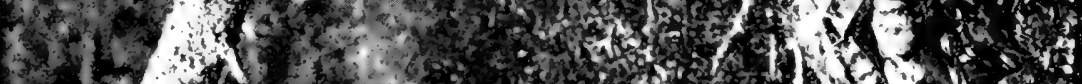

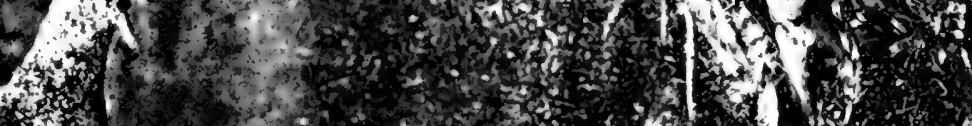

$$
\text { 1. }
$$





\section{The "Hen Hawk"}

a third near by, none of them, however, venturing nearer the bait. -

It was now time for me to watch. With my camera placed in a concealed position, I was on hand before daybreak, the slide of the plate holder drawn, and the release to the shutter ready to operate, if the hawks appeared. As they did not come on this nor on the next morning, it seemed necessary to try to coax them to come.

The traps and bait intended for the skunks were removed; then a fowl was killed and parts of it put about the swamp upon stakes five or six feet high. These parts were taken by something in the morning and late afternoon, probably by the hawks, although the owls may have secured some pieces that were not taken before dark. This feeding process was kept up for four days, the food being renewed several times in some cases, and then all remaining bait was removed from the stakes. Again fresh bait was placed by the stump, as the boy had had it in the beginning.

The camera was placed in position as before, and long before daylight I was in my place of concealment with the release apparatus adjusted ready to photograph, if the opportunity presented itself. The gray appeared in the east, then followed the beautiful 


\section{The "Hen Hawk"}

coloring that sometimes appears just before sunrise, but no visitors came. The morning slowly wore on until ten o'clock, and if the hawks had not breakfasted, they must have been hungry indeed, judging from my own feelings. I had now been working ten days, and had not made a single exposure. It was rather discouraging; but recalling other photographs for which I had waited years, and for which I had worked steadily for days at a time, I was not warranted in giving this one up. The following morning was spent in useless waiting, as also was the next. Then followed another brief baiting period from the stakes, and an early morning watch. It was nearly eight o'clock and I was ready to give up, to try another morning, when, as if from the sky, a beautiful redtailed hawk dropped gracefully upon the perch arranged for him. He folded his wings, stood at his full height with his neck outstretched, his head slightly turned, and seemed to eye the bait suspiciously. Quickly I opened and closed the shutter, the snapshot was made, and a moment later he was sailing over the tree tops, seemingly whistling back to me "Kee-e-e." In due time the negative was developed, and before it was dry it was named "Looking the Situation Over."

In the days that followed two other negatives were 
made, and one, a particularly fine one, was called "Attention."

Those were pleasant days spent with the "hen hawks," and I learned many interesting and instructive things, but my ingenuity and patience were taxed to the utmost to outwit those wary wild birds.

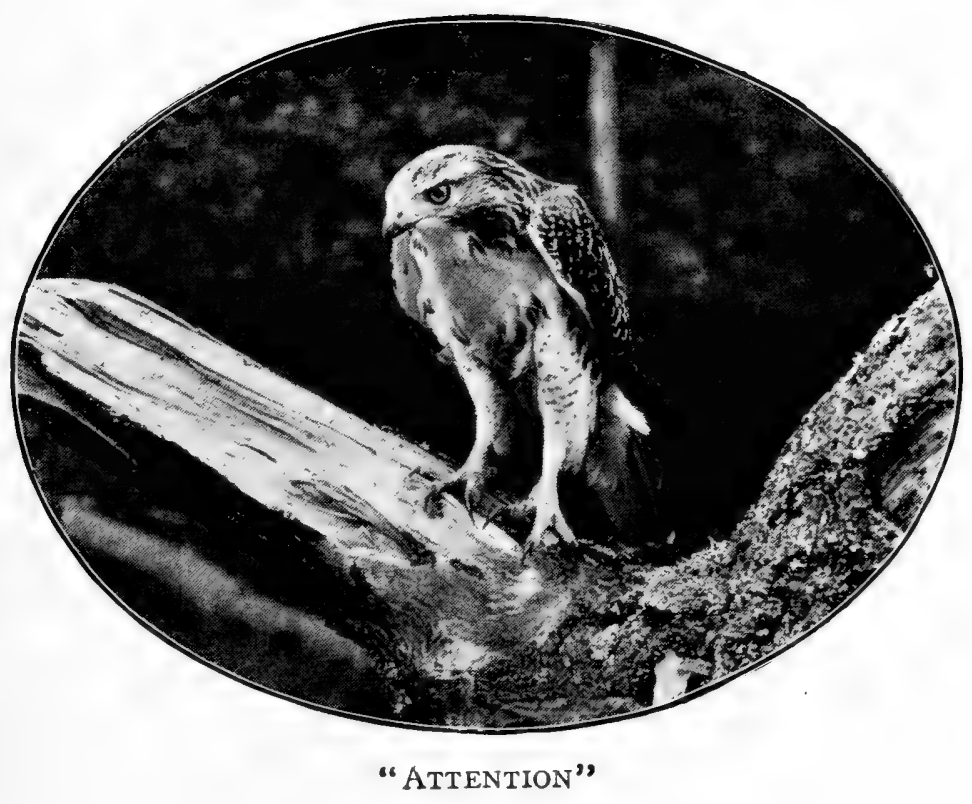




\section{THE SPARROW HAWK}

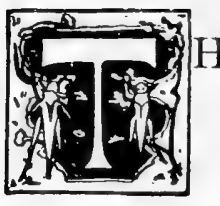

succession.

HE sparrow hawk is sometimes called the "killy hawk," from the sound of its note, "killy-killy-killy," repeated in rapid This beautiful and singularly colored little bird is quite plentiful in the northern part of the United States in summer, but at the approach of winter many migrate to the Southern, States.

This hawk usually nests in large woodpecker holes, and consequently rears its brood quite close to the habitation of man. The period

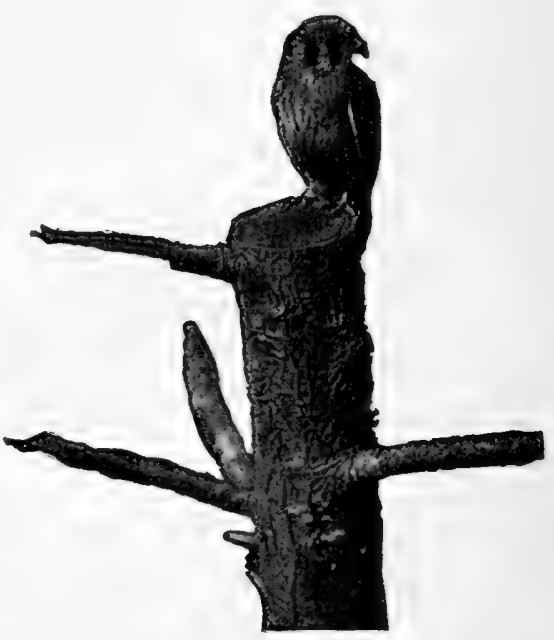

Sparrow HaWk of incubation is about three weeks, and for several days after hatching the young are covered with a very soft down; in fact some of the down is not molted by the time the young birds are ready to fly. 


\section{The Sparrow Hawk}

It is a bird of the open country, rather than of the deep woods, and often it may be seen perched upon a dead limb of a tree by the meadow, watching for a mouse or a grasshopper. When the hawk has located its quarry, it hovers above it for a moment, then, dropping quickly, seizes it with its sharp talons, and bears it away to the perch, to be devoured at leisure. I have often watched these birds feasting upon grasshoppers; and so intently were they engaged that I could approach very near their watch towers without seeming to disturb them in the least. One August afternoon I very unexpectedly came upon a sparrow hawk as he sat upon a stub, and as he paid no attention to me I watched him for some time. Within half an hour he caught and brought to the stub twelve large grasshoppers, which he devoured with apparent relish. This hawk feeds upon other insects also, seeming to have a special liking for crickets and spiders.

When the insects upon which he feed's are scarce, he gives more attention to the capture of mice; at such times he may be found about haystacks and even farm buildings, ready to capture any mouse that dares venture from under cover. Probably when food is scarce this hawk occasionally captures a bird, but this is the exception, rather than the rule. The 


\section{0 \\ The Sparrow Hawk}

fact that it is a hawk and has been known even occasionally to capture a bird or a chicken is, in the eyes of many people, reason enough for exterminating it. They do not stop to consider the great amount of good it has done in destroying mice alone. From the nature of its food, this bird should be protected by law, instead oi being a mark for every passing gunner.

The sparrow hawk lives in harmony with most other birds, even when nesting near them. Last summer I discovered two old maple stubs standing about twenty feet apart by the edge of a meadow; in one of these were flickers nesting, in the other were three hungry young sparrow hawks always clamoring to be fed. I watched these two families until the young of each flew away, and not once did I observe the sparrow hawks troubling the flickers. On the contrary, the sparrow hawks were a help, keeping all larger hawks and crows at a distance.

The blue jay appears to have a great dislike for the sparrow hawk, and on several occasions I have seen three or more blue jays noisily pursuing one hawk. I remember an incident of this kind that happened in the autumn of I900 in a large appleorchard, where I was photographing the nest of a red squirrel. When I first entered the orchard I 


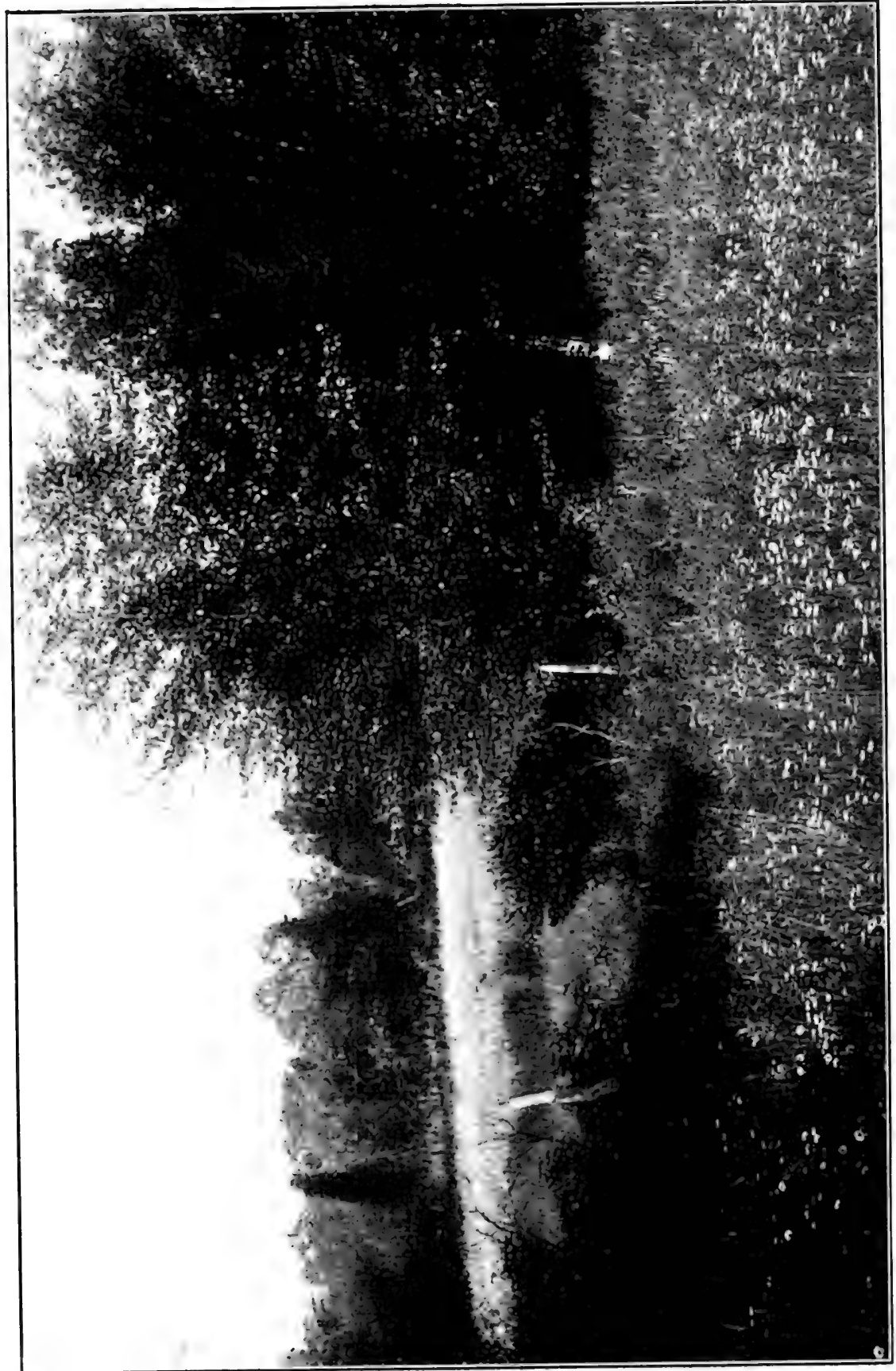




\section{The Sparrow Hawk}

noticed the hawk perched on the top of a tree, and as he was not far from the squirrel's nest, I frequently looked his way. It seemed rather unusual to me that this species of hawk should remain on one perch for such a long time, so I drew near to the tree. As I did so the bird gently raised his wings, vibrating them two or three times, as if to make sure of them, and flew to a near-by tree; but the flight indicated to me that one of its wings had been slightly injured. I did not attempt to make the bird fly again, but after watching it a few moments I returned to my task.

In an hour or so five blue jays came to the orchard from a grove not far away, and, as is usual with these birds at this season of the year, they were noisy and ready for any sort of a frolic. Shortly after their arrival they discovered the sparrow hawk; instantly their crests were lowered, and for a moment their harsh notes were silenced. Recovering from their apparent surprise at finding a hawk so motionless, they soon found their voices: and one would scarcely believe that five birds could make such a noise.

At first the jays were content to remain some distance from the hawk and revile him in their language, but as this had little visible effect on him, and especially as he did not move, they approached nearer and nearer by degrees, finally alighting upon the tree 


\section{4 \\ The Sparrow Hawk}

with him; whereupon the hawk flew to another perch, only to be followed in a most tantalizing manner by the scolding jays. Several times this was repeated, the jays following closer and closer each time, till at last the hawk became so enraged that he made a dash at the nearest jay, striking him with his talons in such a way as to pull out a few feathers. At this unexpected onslaught of the hawk, the noisy band of jays retreated to the forest, leaving "Killy" in the orchard.

The sparrow hawk, if taken from the nest while quite young, becomes one of the most charming of bird pets. The beautiful coloring of the feathers, the unusual intelligence and the graceful movements of the bird endear him to the few who have really come to know him. A friend of mine who had a tame one several years ago, told me that of all the birds he had tamed and loved, he cared most for his sparrow hawk. This hawk seemed to show no affection for any one but its master; but of him it was very fond, often, when he was out in the open field, alighting most unexpectedly upon his head or shoulder It spent the greater part of the time about the open fields and orchard catching insects and mice; occasionally it would go to the woods, being absent sometimes nearly all day. The hawk enjoyed nothing 

better than hunting mice, if only his master would overturn the flat stones and boards for him, and it

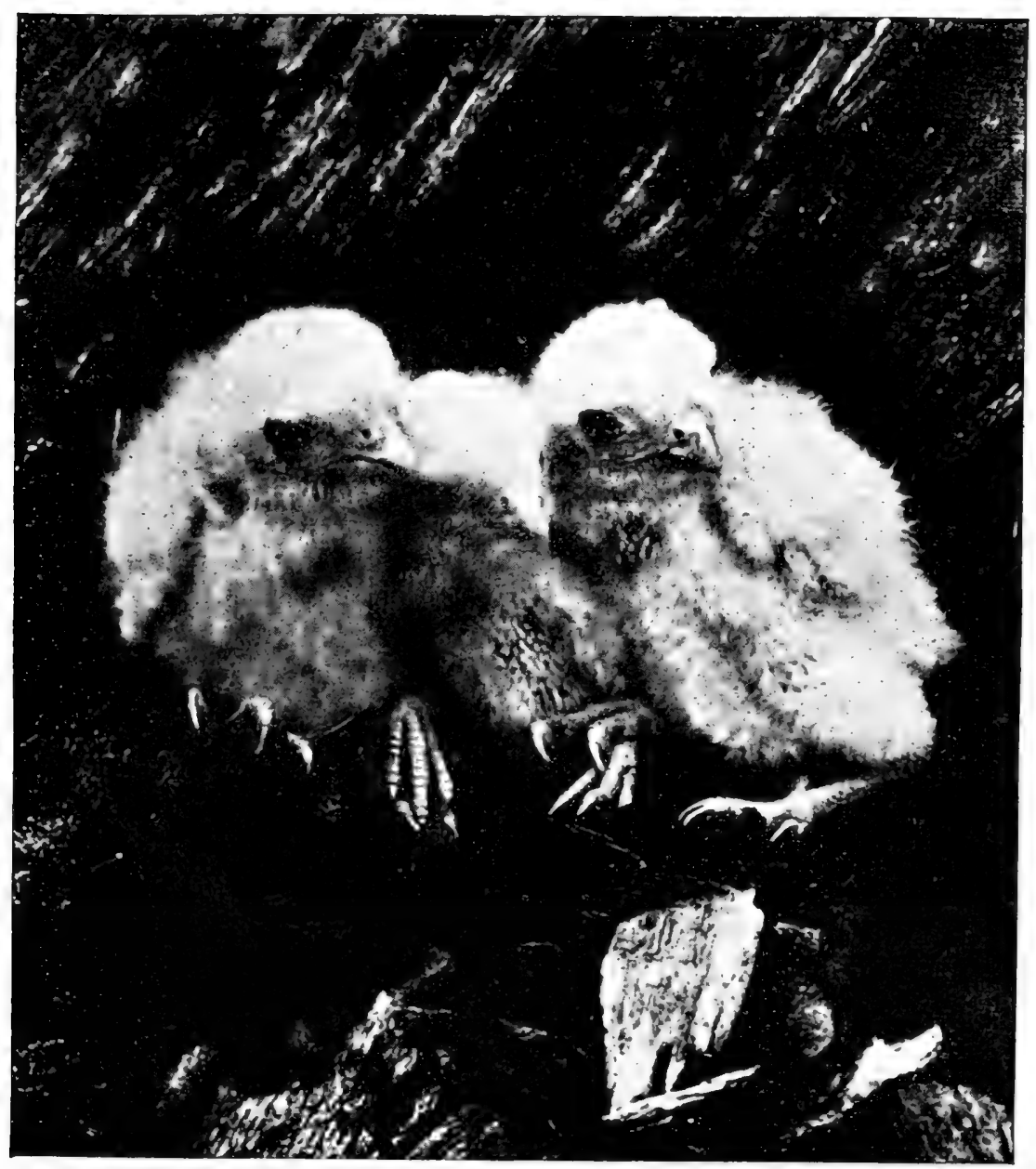

Young SPaRrow HaWKS.

was surprising how expert he was in capturing them. $\mathrm{He}$ would catch them even when his appetite was 


\section{$33^{8} \quad$ The Sparrow Hawk}

satisfied, and, after killing them, would leave them on the fence or the limb of a tree.

This pet hawk rendered another good service, by guarding the chickens, although it was probably unintentional on his part, putting to flight all crows or hawks that came about the poultry yard. One day, while endeavoring to drive away a large hawk, a fierce fight ensued. The larger hawk retreated toward the woods, but the combat was kept up until, as they rose higher and higher, the watchers at the house lost sight of them. When last seen each was trying to gain the advantage that the more elevated position afforded. The little sparrow hawk never came back; whether he fell a victim to the larger hawk or whether he was shot by some thoughtless gunner will probably never be known.

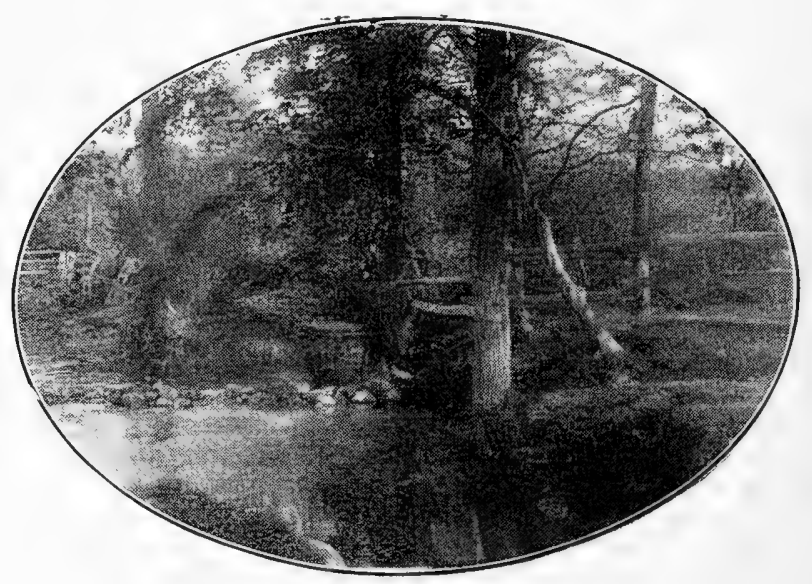


. 



\section{EXTINCT ANIMALS}

\section{By E. RAY LANKESTER, F.R.S.}

With numerous illustrations. \$I.75 net, postage extra

An account of animals, many of which lived on the earth in ages before written history. The author bases the book on his popular lectures, and although the story is told so simply that children cannot fail to understand it, it is in no way lacking in scientific value, and will be full of interest for older people as well. The story of these animals is in some measure the story of the earth itself.

\section{'THE COUN'TRY DAY BY DAY}

By E. KAY ROBINSON

Illustrated. \$I.75 net, postage extra

A diary of nature for a twelvemonth, descriptive of English country scenes, but of interest to the-American nature-lover by reason of its marked iiterary quality and the wealth of detailed observation which it contains. It is a note-bouk of birds, flowers, anımals, and all the varied life of the woods and fields, unfolding, in a way which will delight those who know the country, the progress of nature day by day throughout the year There are numeruus pictures from photographs taken in the field by the author.

\section{THE OPEN ROAD}

Compiled by EDWARD V. LUCAS

Some 125 poems and twenty-five prose passages, representing over sixty authors. $\$ \mathbf{I} .5^{0}$

"The selections tell of farewells to winter and the town of spring and the beauty of the earth, of lovers, of sun and cloud and the windy hills, of birds, blossums, and trees-in fact of everything that makes work wellnigh impossible when the world of nature begins to awake from its long sleep."-Critic.

"A very charming book from cover to cover."-Dial.

\section{Henry Holt and Company Publishers $\left(x,{ }^{\circ}\right.$ ) New York}




\section{A GUIDE TO \\ THE STUDY OF FISHES}

By DAVID STARR JORDAN

2 volumes, 934 illustrations. $\quad$ I223 pp. \$12.00 net, postage extra. 32 pp. Prospectus free on application.

A comprehensive work, at once scientific and popular, by the leading American ichthyologist. It discusses the structure, habits, evolution, and economic value of fishes. It treats of the characteristics of chief groups, emphasizing those which by reason of divergence from typical forms are of especial interest. Extinct fishes are discussed along with their living relations. Nothing has been spared to make the work, in illustration and mechanical execution, worthy of a magnum opus. There is an abundance of pictures in half tone and other forms of black-andwhite illustration, and the frontispiece of each volume shows in colors some of the remarkable fish brought by the author from his Pacific explorations. There are also portraits of the world's leading ichthyologists. The work is issued in two sumptuous, large octavos, and is intended to be a valuable handbook for technical students and interesting to anglers and nature lovers.

\section{AMERICAN INSECTS}

By VERNON L. KELLOGG

With 8I2 figures and I I colored plates. 647 pp. $\$ 5.00$ net, postage extra.

This sumptuous volume covers the entire American insect world, including moths, butterflies, and beetles, to which separate volumes are often devoted. Written in a style to interest the general reader, the arrangement is systematic and reasoned, and it is probably the most valuable handbook of the subject for the technical student or amateur collector. Habits, life, history, relations to man, to other animals and to plants are given special prominence. It is distinguished by much new matter, the results of the author's ingenious observations, and by many original pictures illustrating species not before figured in general insect books.

\section{HENRY HOLT \& CO. 29 West 23 N Street}





t. W.

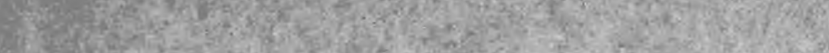

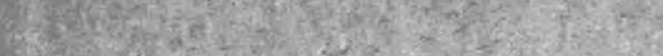

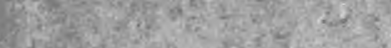

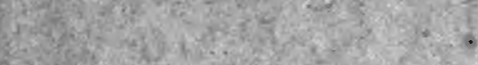

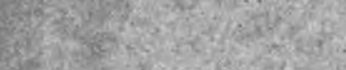

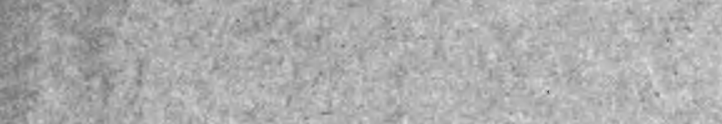

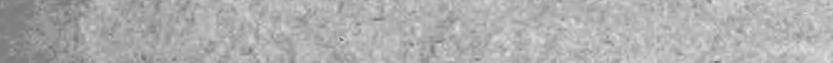

(15) (c)

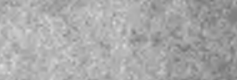
M.

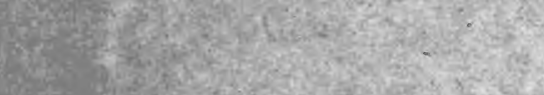

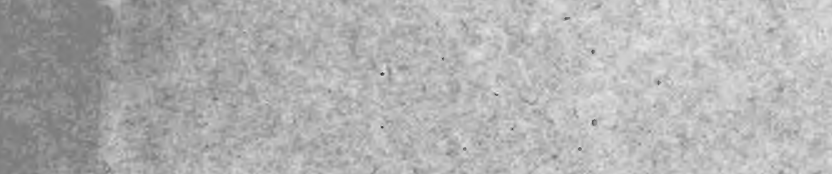

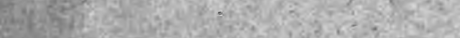

The Q 200

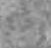

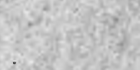

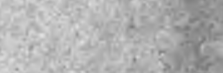
af: 



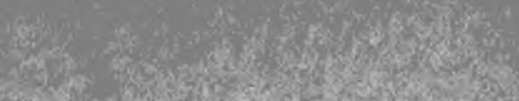

(1) if

iflong

if)

H)

Nifly

(I)

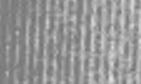

(1)

1.

I)

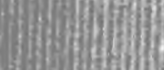

Hin:

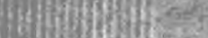

Hiving

nisily)

iff(y)

is):fis:

$\cos ^{\circ}$

(2)

tisis

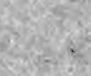

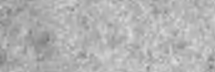

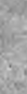

is

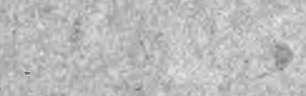

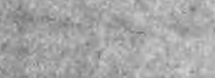

(I)

ine

1.).

(1)

if

(f)

Hing

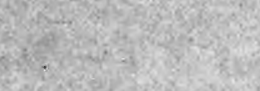

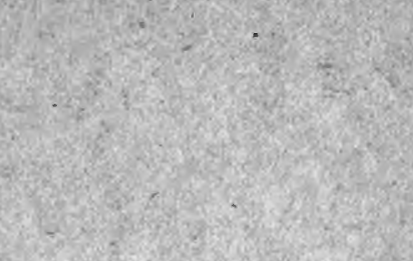

3.

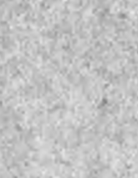

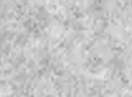

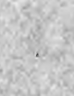

s.
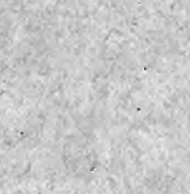

(3.2.

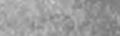

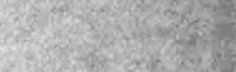




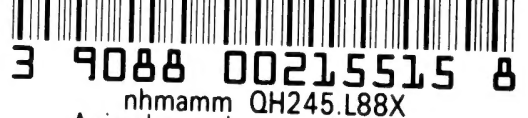
Animal snapshots and how made, 